\title{
Timing and drivers of exhumation in the hinterland of the North American Cordillera from detrital zircon $\mathrm{U}-\mathrm{Pb}$ and $(\mathrm{U}-\mathrm{Th}) / \mathrm{He}$ double-dating
}

\author{
By \\ Kathleen Graham \\ Submitted to the graduate degree program in Geology and the Graduate Faculty of the \\ University of Kansas in partial fulfillment of the requirements \\ for the degree of Master of Science.
}

Co-Chairperson: Dr. Tandis Bidgoli

Co-Chairperson: Dr. J. Douglas Walker

Dr. Andreas Möller

Date Defended: February 1, 2019 
The thesis committee for Kathleen Graham certifies that this is the approved version of the following thesis:

\section{Timing and drivers of exhumation in the hinterland of the North American Cordillera from detrital zircon $\mathrm{U}-\mathrm{Pb}$ and $(\mathrm{U}-\mathrm{Th}) / \mathrm{He}$ double dating}

Co-Chairperson: Dr. Tandis Bidgoli

Co-Chairperson: Dr. J. Douglas Walker

Date Approved: 01 FEBRUARY 2019 


\section{ABSTRACT}

The late Cretaceous to early Cenozoic hinterland of the North American Cordillera is widely recognized as an orogenic plateau. Although most studies suggest that this highland was in place by the Eocene, the timing and underlying drivers of the plateau's development and eventual demise are not well known. To better understand this evolving orogenic system, this study focuses on constraining the age, provenance, and depositional lag-time of Eocene sediments along the California continental margin. These sandstones were sourced, in large part, from the western margin of the highland and may, therefore, offer clues to its development.

A total of 2,163 new detrital zircon $\mathrm{U}-\mathrm{Pb}$ ages were obtained from 16 samples to confirm the published provenance of the sandstones and/or recover new grain-age populations. The U-Pb ages reveal the major sources for zircons: Permian-Triassic, Jurassic, and Cretaceous arc rocks, the Paleo- and Mesoproterozoic Mojave and Mogollon Highlands, and the Idaho Batholith/Challis volcanic center. Samples north of the Transverse Ranges display a stronger arc signature, while samples south of them were sourced from the Mojave and Mogollon Highlands. 159 new (U-Th)/He ages obtained from a subset of the zircons analyzed from each sample, record either one or two significant age peaks. The majority of samples have a strong latest Cretaceous cooling signature; however, most samples also record Eocene cooling. The six samples from the Santa Ynez Mountains and from Vacaville area contain cooling ages that likely reflect post-depositional resetting of samples and are not considered for further interpretation. Observations from the (U-Th)/He dates suggests that most samples with probable sources inboard of the Sierra Nevada record short lag-times, indicating little to no delay between source exhumation and sediment deposition. 
Overall, the (U-Th)/He dates suggest that hinterland sediment source regions were affected by major pulses of exhumation in the late Cretaceous and Paleocene to Eocene. Late Cretaceous exhumation fits well with the timing of Sevier deformation, but rapid exhumation in the Eocene is not readily explained by the tectonic framework of the region. We hypothesize that Laramide-related tectonism in combination with rapid erosion due to changing climate are responsible for this Eocene exhumation. 


\section{ACKNOWLEDGEMENTS}

I am thankful for my devoted adviser, Dr. Tandis Bidgoli, who has graciously guided me through this project, and has also been an endless source of encouragement and invaluable insight through my degree. I am also indebted to my co-advisor, Dr. J. Douglas Walker, who provided funding for my field work as well as guidance and support, and Dr. Andreas Möller for being a patient and expertly helpful committee member throughout this project. I would also like to thank Amy Olson for her help as a wonderful field assistant. Also, I would like to acknowledge Ty Tenpenny, Dr. Jeff Oalmann, and Dr. Joe Andrew for their time, patience, and instruction working in the KU Isotope Geochemistry Lab. Credit and thanks are also necessary to Rudra Chatterjee and Dr. Daniel Stockli, at the University of Texas Thermochronometry Laboratory, for their time and direction during (U-Th)/He analysis. Dr. Noah McLean has also been of great help with data reduction and has provided direction and critiques for this project that have helped improve the quality of this work. Likewise, many of my co-students at KU deserve thanks for many hours of support, discussion, and helpful critiques over my time as a graduate student. Lastly, my friends and family deserve more thanks than I can give as they have been a solid foundation for me emotionally through my post-graduate career. Support for this project was provided by the Kansas Geological Survey, University of Kansas Geology Department, American Association of Petroleum Geologists, Association for Women Geoscientists, Kansas Geological Foundation, and the Association of Earth Science Clubs of Greater Kansas City. 


\section{Table of Contents}

ABSTRACT

ACKNOWLEDGEMENTS

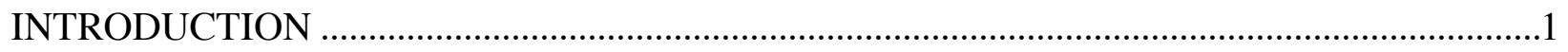

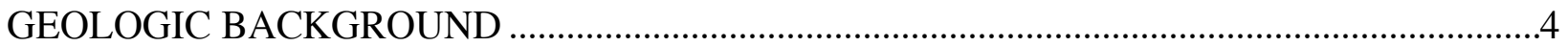

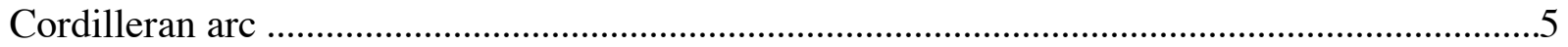

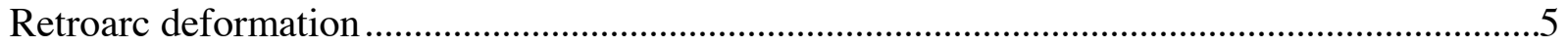

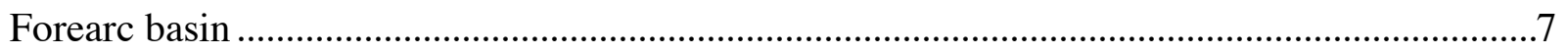

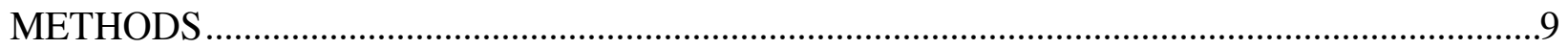

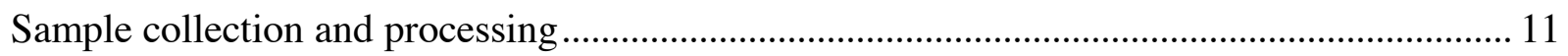

Detrital zircon U-Pb geochronometry ........................................................................ 12

Detrital zircon (U-Th)/He thermochronometry .............................................................. 13

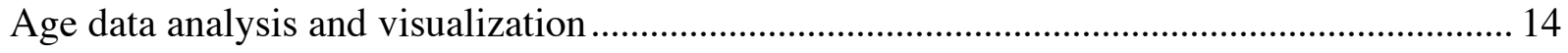

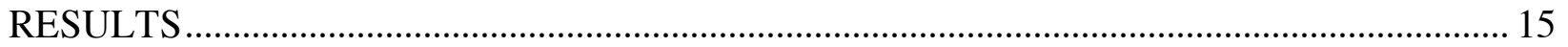

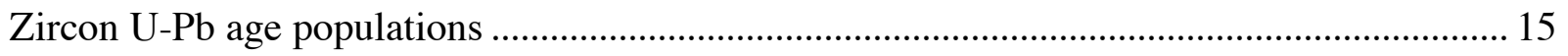

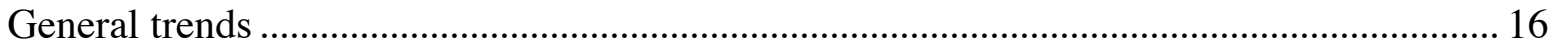

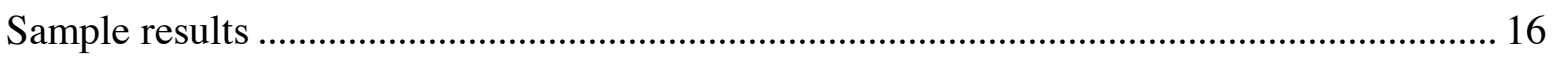

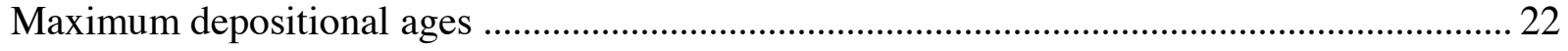

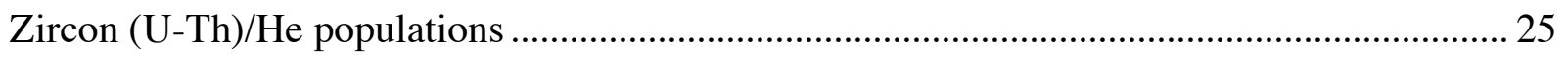

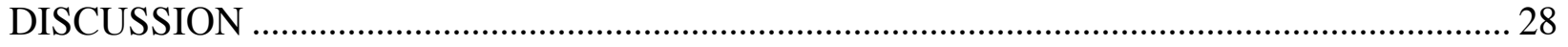

Provenance Comparisons to Published Data ..................................................................... 28

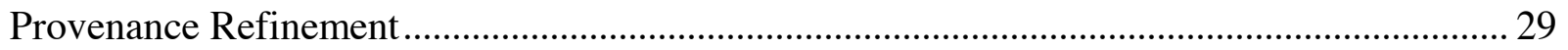

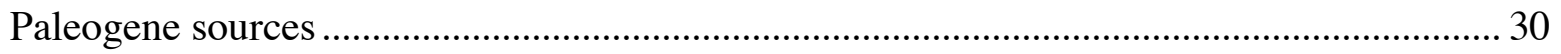

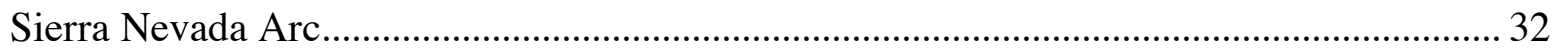


Mojave Desert \& the Mogollon Highlands

Source Region Lag-time and Cooling Date Trends.................................................................. 34

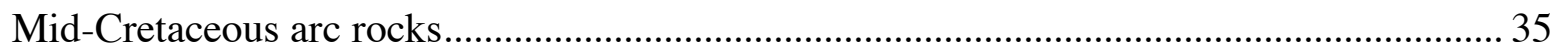

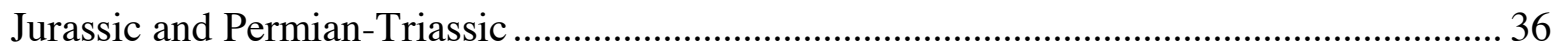

Late Cretaceous and Proterozoic ............................................................................................. 37

Summary of Lag-time and Cooling Date Trends ............................................................... 38

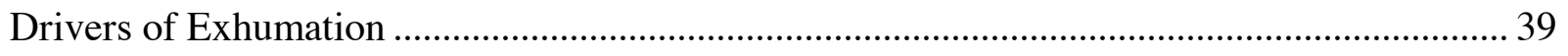

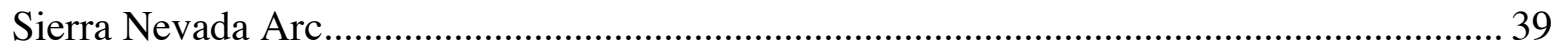

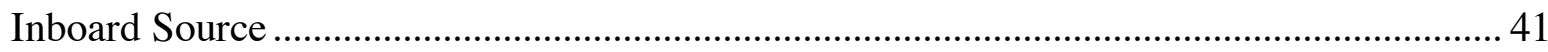

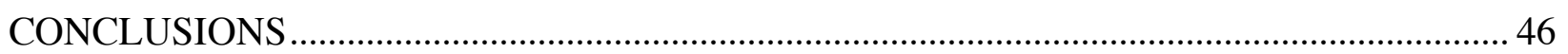

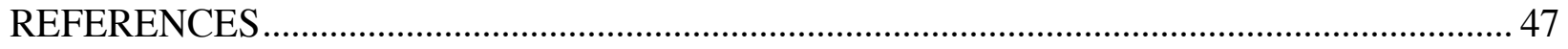

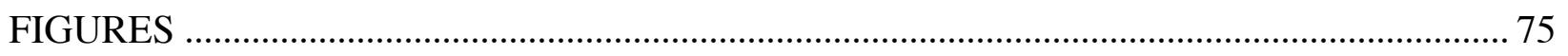

Figure 1-Overview Map of Western U.S. Cordillera ………………………………...... 76

Figure 2-Schematic of Double-dating and Lag-time Analysis ....................................... 78

Figure 3-U-Pb KDE Diagrams .............................................................................. 80

Figure 4-U-Pb Age Populations as Pie Diagrams.......................................................... 82

Figure 5-Map of Sample Provenance Relationships ....................................................... 83

Figure 6-U-Pb vs. (U-Th)/He Age Plots ..................................................................... 84

Figure 7-(U-Th)/He vs. Effective Uranium Plots ......................................................... 85

Figure 8-(U-Th)/He KDE Diagrams …………………………………………….... 87

Figure 9-(U-Th)/He Age Spectra as Pie Diagrams....................................................... 89

Figure 10-U-Pb Multi-Dimensional Scaling Relationship Results ................................. 90

Figure 11-Eocene Paleogeographic Reconstructions and Source Regions..................... 92

Figure 12-Lag-time Results by Sample ........................................................................ 94

Figure 13-Summary Maps of Lag-time and Cooling Age Trends..................................... 98

Figure 14-Drivers of Cooling Timeline …………………........................................... 99

Figure 15-Models for Two-Stage Cooling .................................................................... 101

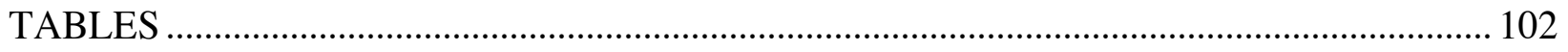

Table 1. Location, name, and age of samples.................................................................. 102 


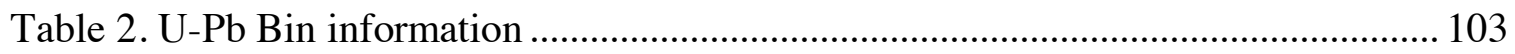

Table 3: Maximum Depositional Age Results.................................................................. 104

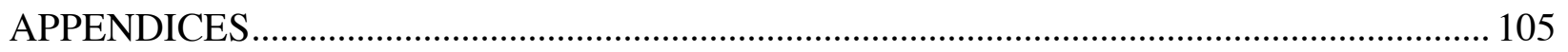

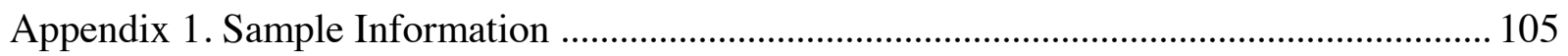

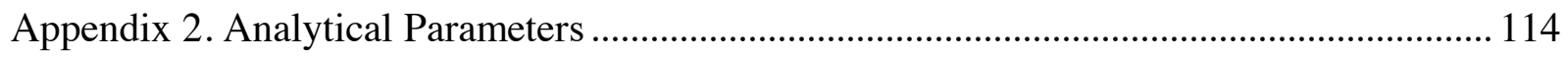

Appendix 3. U-Pb Secondary Reference Material Values for the Analytical Sessions .......... 115 Appendix 4. U-Pb Zircon Data \& Concordia Plots ....................Error! Bookmark not defined.

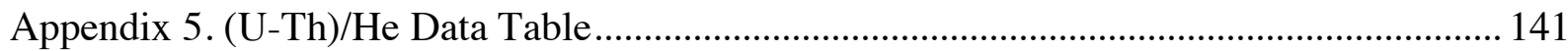

Appendix 6. Sources and Grain Counts for Multidimensional Scaling Analysis.................. 144

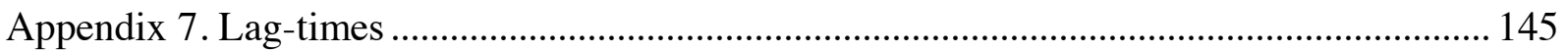




\section{INTRODUCTION}

It is widely accepted that a high-standing orogenic plateau, similar to the modern Andean Puna-Altiplano, formed across part of the hinterland of the Jurassic to Eocene North American Cordillera (Figure 1; Coney and Harms, 1984; Dilek and Moores, 1999; DeCelles, 2004; Best et al., 2009; Ernst, 2009; Cassel et al., 2012a; Henry et al., 2012; Cassel et al., 2014; Chapman et al., 2015; Long et al., 2012/2015; Long and Soignard, 2016; Erdman et al., 2016; Copeland et al., 2017). Although the absolute elevation and relief of this plateau, termed the Nevadaplano (DeCelles, 2004), are controversial, studies confirm that the crust was thicker (e.g., Chapman et al., 2015) and more elevated than present day (e.g., Horton et al., 2004). Paleobotanical and isotopic evidence from sites in Nevada and Utah suggest that it stood at about $~ 3-4 \mathrm{~km}$ above sea level (Wolfe et al., 1998; Cassel et al., 2014; Snell et al., 2014). (U-Th)/He age-elevations relationships (House et al., 2001) and stable isotope studies (Mulch et al., 2006) suggest that the Sierra Nevada also stood high and may have formed the western margin of this plateau.

Several lines of evidence suggest that this highland was likely in place by the Eocene (Coney and Harms, 1984; Dilek and Moores, 1999; Best et al., 2009; Cassel et al., 2009; Henry et al., 2012). Timing constraints on peak metamorphism (e.g., Miller et al., 1988; Miller and Gans, 1989; McGrew et al., 2000; Wells and Hoisch, 2008) and development of metamorphic core complexes and synconvergent extensional structures in northeastern Nevada and northwestern Utah (Coney and Harms, 1984; Applegate et al., 1992; Wells et al., 1990; Hoisch and Simpson, 1993; Wells, 1997; McGrew et al., 2000; Druschke et al., 2009; Wells et al., 2012; Long, 2015) support the presence a thick and high-standing plateau by the Eocene. Similarly, paleovalleys that transect the western margin of the plateau are filled with ash-flow tuffs that indicate pre-Oligocene uplift and incision (Cassel et al., 2012a; Henry et al., 2012; Best et al., 
2013; Henry and John, 2013; Cassel et al., 2014).

Although development by the Eocene is generally accepted, the spatial extent, temporal evolution, and underlying drivers for the development and demise of the Nevadaplano are still somewhat uncertain (see discussions in Wakabayashi and Sawyer, 2001; Poage and Chamberlain, 2002; Horton et al., 2004; Clark et al., 2005; Mulch et al., 2006; Molnar, 2010; Henry et al., 2012; Copeland et al., 2017). Published and unpublished thermochronology studies from the region, which have mostly focused on unraveling the history of Basin and Range extension, may offer clues to the temporal evolution of the plateau. Preserved in the footwalls of many of the normal faults are two phases of pre-Miocene exhumation and/or cooling (e.g. Surpless et al., 2002; Stockli et al., 2002, 2003; Lee et al., 2009; Mahan et al., 2009; Ferrill et al., 2012; Gorynski et al., 2013; Walker et al., 2014; Bidgoli et al., 2015). The first is a Late Cretaceous ( $\sim 65 \mathrm{Ma}$ ) event and the second is an Eocene (50-55 Ma) event. The region subsequently entered a period of tectonic dormancy, characterized by low erosion rates (0.02$0.04 \mathrm{~km} / \mathrm{m} . \mathrm{y}$.$) , until initiation of middle to late Miocene extension (Clark et al., 2005; Cecil et$ al., 2006; Maheo et al., 2009; Gorynski et al., 2013; Walker et al., 2014; Bidgoli et al., 2015). Rapid exhumation and/or cooling in the late Cretaceous can be readily attributed to local structures and tectonomagmatic processes at the time (e.g. Hodges and Walker, 1990; Applegate et al., 1992; House et al., 1997; Wood and Saleeby, 1997; Stockli et al., 2002, 2003, Yin 2002, DeCelles, 2004, Clark et al., 2005; Glazner et al., 2005; Bartley et al., 2007; Wells and Hoisch, 2008; Lee et al., 2009; Chapman et al., 2012; Bidgoli et al., 2015). The Eocene phase, however, is more difficult to explain.

Some workers have assigned early Cenozoic crustal cooling in the western Great Basin to Laramide tectonism or unroofing of the southern Sierra Nevada (Miller and Friedman, 1999; 
Wood and Saleeby, 1997; Lee et al., 2009), but the regional tectonic framework does not support widespread tectonic exhumation at the time. Deformation at $~ 80-50$ Ma was concentrated farther east, as documented by basement-cored uplifts in Colorado, Wyoming, and New Mexico (Dickinson and Snyder, 1978; Schmidt et al., 1993) and inboard volcanism (Coney and Reynolds, 1977), consistent with slowing of plate velocities (Engebretson et al., 1985; Seton et al., 2012) and shallowing of the subducting Farallon slab (Coney and Reynolds, 1977; Dickinson and Snyder, 1978; Dumitru, 1991). Mantle-driven processes are also an unlikely cause, as the low-angle geometry of the subducting slab would have restricted mantle circulation across much of the Great Basin until slab rollback and possibly slab break-off occurred in the late Eocene to Oligocene, as recorded by the ignimbrite flare-up (Humphreys, 1995; Dickinson, 2006; Henry et al., 2012; Best et al., 2013; Smith et al., 2014; Yonkee and Weil, 2015) and accelerated deformation of the Green River Basin in Wyoming (Fan and Carrapa, 2014).

Another complication to elucidating the drivers of exhumation in the study area is the character and role of changing climate in the early Cenozoic (Zachos et al., 2001, 2008). The interplay between climate, tectonics, and erosion is complex, with potential feedbacks that can create, shape, and destroy topography (e.g., Molnar and England, 1990; Wilett et al., 2006; Whipple, 2009). The early Cenozoic was punctuated by both the Paleocene-Eocene Thermal Maximum (PETM; 55 Ma) and the long-term climatic maximum - the Early Eocene Climatic Optimum (EECO; 51-53 Ma; Koch et al., 1992; Robert and Chamley, 1991; Knox, 1998; Zachos et al., 2001, 2008). These events may have had profound impacts on precipitation patterns, chemical weathering rates, erosion rates, and drainage systems that could contribute to the Eocene exhumation signal.

Critical to the evaluation of potential drivers of Eocene exhumation is understanding the 
provenance of Eocene sediments as well as the pace of processes in western North America, both of which should be recorded in Eocene forearc sediments west of the evolving highland.Provenance studies of Late Cretaceous to Eocene forearc sediments have established the groundwork for this study which they record shifts in source regions, primarily inboard of the Sierra Nevada (e.g. Jacobsen et al., 2011; Cassel et al., 2012b; Sharman et al., 2015). These shifts reflect changes in both the drainage systems and the overall landscape, although the tempo of these proceses and their underlying drivers are still obscure and require further exploration.

This study tests competing models for exhumation of the western Nevadaplano through systematic detrital zircon U-Pb and (U-Th)/He double-dating of Eocene forearc and trench-slope sediments. We obtained 2,246 new detrital zircon U-Pb ages and 159 (U-Th)/He dates obtained from 16 samples of Eocene-age sandstones across the Great Valley, Sierra Nevada Foothills, and Coastal ranges in California (Figure 1). The paired ages are used to better constrain the depositional age, provenance, and depositional lag time (Rahl et al., 2003; Ruiz et al., 2004; Reiners et al., 2005; Campbell et al., 2005; Saylor et al., 2012; Michael et al., 2014) of the units, which can be used to evaluate sediment distribution pathways and the rates of source region processes, from exhumation of potential sediment sources to their ultimate deposition.

\section{GEOLOGIC BACKGROUND}

The Mesozoic to early Cenozoic Cordilleran orogenic system in the western U.S. is characterized by prolonged Andean-type subduction of the Farallon plate, leaving a trail of deformation from the west coast of California to Colorado. Major components of this system are: (1) a magmatic arc that includes the Sierra Nevada and Pennisular Ranges batholiths (Hamilton and Myers, 1967; Silver and Chappell, 1988; Ducea, 2001), (2) a retroarc made up of a broad zone of dominantly east-vergent contractional deformation (Yonkee and Weil, 2015 and 
references therein), a hinterland plateau (Ernst, 2010 and references therein), and a foreland (DeCelles, 2004 and references therein), and (3) a forearc basin that contains the record of arc magmatism and exhumation of the western margin of this system (DeGraaff-Surpless et al., 2002 and references therein).

\section{Cordilleran arc}

Arc magmatism began in the late Permian and continued through the mid-Cretaceous, forming the Sierra Nevada and Peninsular ranges batholiths that are in place today (Figure 1; Barth et al., 2011). Construction of the magmatic arc began with Triassic-Jurassic intraoceanic volcanic arcs that later accreted to the North American continent, forming terranes of the Klamath Mountains and Sierran Foothills (Dickinson, 2008). Primary batholith emplacement is associated with major pulses of magmatism in the Jurassic (200-135 Ma) and mid-Cretaceous (125-100 \& 100-85 Ma) (Barton et al., 2011), but ceased by 80 Ma as magmatism migrated inland with flattening of the subducting slab beneath western North America (Lipman, 1992). The most voluminous periods of arc magmatism built the main batholith, which youngs from west to east with the migration of arc magmatism until cessation (Chen and Moore, 1982). In the Peninsular Ranges, just to the south of the Sierra Nevada arc and separated by the San Andreas fault, plutons are primarily mid-Cretaceous in age. Some late Cretaceous plutons were also emplaced in the eastern part of the range while flat-slab subduction occurred, and magmatism ceased to the north (Kimbrough et al., 2001).

\section{Retroarc deformation}

During arc emplacement, deformation was concentrated behind the arc, along dominantly east-vergent structures of the Luning-Fencemaker, central Nevada, and Sevier fold-thrust belts. During late Cretaceous to Eocene flat-slab subduction (Laramide orogeny), deformation 
developed farther inland and is characterized by thick-skinned, basement-cored uplifts in Wyoming, Colorado, and New Mexico (Dickinson and Snyder, 1978; Schmidt et al., 1993; DeCelles, 2004; Wells and Hoisch, 2008). Laramide deformation generally reflects the spatial extents of flat-slab subduction at the time (Figure 1; Wells and Hoisch, 2008).

In the hinterland of the North American Cordillera (Figure 1) was a large Andean Altiplano-type orogenic plateau, coined the Nevadaplano (DeCelles, 2004). High elevations of the plateau were achieved by crustal thickening $(\sim 38-70 \mathrm{~km})$ that was the result of Sevier thrusting during the Cretaceous to Paleogene (Coney and Harms, 1984; DeCelles, 2004; Colgan et al., 2006; Lerch et al., 2007; Wells and Hoisch, 2008; Ernst, 2010; Druschke et al., 2011; Snell et al., 2014; Chapman et al., 2015; Long et al., 2015; Yonkee and Weil, 2015). Thick crust in eastern Nevada, southern Idaho, and northwestern Utah is also evidenced by a belt of metamorphic core complexes which represent deep thrust burial and subsequent exhumation (Coney and Harms, 1984; Hodges and Walker, 1992; DeCelles, 2004; Wells and Hoisch, 2008).

Although the spatial extents of this hinterland plateau are not well established, particularly its northern and southern limits, the Sierra Nevada is inferred to define the western margin of the plateau. The morphology of the western portion is inferred to have been a lowrelief ramp based on the distribution of Oligocene ash-flow tuffs deposited in Eocene paleovalleys (Cassel et al., 2012a; Henry et al., 2012; Best et al., 2013; Henry and John, 2013; Cassel et al., 2014). These paleovalleys drained east-west and were likely sourced from central Nevada, where a drainage divide likely was present (Figure 1; Cassel et al., 2012a; Henry and Faulds, 2010; Henry et al., 2012; Best et al., 2013). The development of the Nevadaplano was likely complete by the Eocene, and was followed by Miocene extensional dismemberment, resulting in the Basin and Range topography present today (McQuarrie and Wernicke, 2005; 
Colgan and Henry, 2009; Henry and Faulds, 2010; Long et al., 2012).

\section{Forearc basin}

By the latest Jurassic or early Cretaceous, a forearc was developed along the western continental margin (Dickinson and Seely, 1979; Ingersoll, 1979; Bottjer and Link, 1984). The Great Valley forearc, composed of both the Sacramento and San Joaquin basins, developed in the late Jurassic and continued to subside and accumulate sediment through the Paleogene (Ingersoll, 1979/1983; Bartow, 1991; DeGraaf-Surpless et al., 2002; DeCelles, 2004). Basin development is associated with accretion of the Klamath Mountains and Sierran Foothills terranes and later with Franciscan subduction (Dickinson and Seely, 1979; DeCelles, 2004). Late Jurassic to Cretaceous sediments, known as the Great Valley Group, rest on the late Jurassic Coast Range ophiolite and increase in thickness towards the west (Ingersoll, 1983; Moxon and Graham, 1987; DeCelles, 2004). In the east, upper Cretaceous sediments lie on Sierran arc basement rocks and are unconformably overlain by Paleogene units (Moxon and Graham, 1987; Moxon, 1988). Sediments in the Great Valley form an east-dipping homocline due to later uplift of the western side of the forearc basin (DeGraaf-Surpless et al., 2002).

Previous provenance analyses of Eocene forearc sediments suggests a shift from local to extra-regional sediment sources (Degraaf-Surpless et al., 2002; Jacobsen et al., 2011; Cassel et al., 2012b; Sharman et al., 2015). In the Cretaceous, sources for forearc sediments were in the magmatic arc, indicating it was a significant topographic feature at that time (Degraaf-Surpless et al., 2002; Jacobsen et al., 2011; Sharman et al., 2015). By the Eocene, a transition occurred where drainages crossed the arc and tapped inboard. Drainages through the Eocene progressively moved inland, transecting the arc, and by the late Eocene were sourcing as far east as central Nevada (e.g. Cassel et al., 2012b). Previous studies also noted spatial trends in provenance from 
north to south. Generally, sediments in the Great Valley received detritus primarily from the Sierra Nevada, along west-flowing drainages as well as to the north in the Idaho Batholith (Dumitru et al., 2013; Sharman et al., 2015). To the south, sediments received progressively smaller amounts of detritus from the magmatic arc, and increasing amounts from inboard regions in the eastern Mojave and Mogollon Highlands (Jacobsen et al., 2011; Sharman et al., 2015).

The Eocene forearc strata that are the focus of this study are exposed across the study area in outcrop belts along the margins of these basins and further detail on each sampled unit is provided in Appendix 1. The sampled intervals were deposited, from north to south, specifically in the Sacramento and San Joaquin (referred to here as the Great Valley), the Salinian/Gualala/San Francisco Bay blocks (referred here as simply the Salinian Block), the Sierra Madre, and the Santa Ynez Mountains areas. We sampled early to middle Eocene submarine canyon fill (e.g. the Markley Sandstone; Almgren and Filewicz, 1984; Milam, 1985; Meganos Formation; Cherven, 1983; Moxon, 1990; Sullivan and Sullivan, 2012), shallow marine shelf sediments (e.g. Tesla Formation; Nilsen and Clarke, 1975; Throckmorton, 1982; Bartow, 1985), to deep sea fan and turbidite sequences (e.g. Point of Rocks Sandstone; Seiders and Cox, 1992; Sharman et al., 2013) and fluvial sandstones (e.g. Ione Formation; Allen, 1929; Creely and Force, 2007) for this group. The early to middle Eocene Salinian Block samples are comprised of deep-sea basinal sediments (e.g. Butano Sandstone; Greystone Formation; German Rancho Formation; Beaulieu, 1970; Turner, 1970; Short, 1986; Anderson, 1998; Elder, 1998; McDougall, 1998; Wentworth et al., 1998; Doebbert et al., 2012) that have been translated northward along the San Andreas fault since the Eocene (Ross, 1978; Howell and Vedder, 1978; Mattinson, 1990; Wentworth et al., 1998; Kidder et al., 2003; Jacobsen et al., 2011). In the Sierra Madre, we sampled two units: an unnamed early to middle Eocene sandstone from a turbidite 
sequence (Seiders and Cox, 1992) and the late Eocene-early Oligocene fluvial Simmler Formation (Blake, 1982; Balance et al., 1983; Vedder et al., 1991; Wilson et al., 2000) both of which were originally deposited on the southernmost Salinian Block (Vedder et al., 1991; Sharman et al., 2015). The Salinian Block is presently in northern and central California (Figure 1), but based on published restorations, originally lay adjacent to the Mojave Desert in the Eocene (Ross, 1978; Howell and Vedder, 1978; Mattinson, 1990; Wentworth et al., 1998; Kidder et al., 2003; Sharman et al., 2015). Lastly, the Santa Ynez Mountains samples, deposited in the Transverse Ranges forearc, represent an Eocene retrogradational-progradationalretrogradataional marine section (including the Juncal Formation, Matilija Sandstone, and Coldwater Sandstone). In the late Eocene, deposition switched to the fluvial Sespe Formation (Stauffer, 1967; Vedder, 1972; Nilsen and Clarke, 1975; Thompson, 1988; Jiao and Fritsche, 1994; Dickinson, 1995; Howard, 1995). Similar to the Salinian Block, the Santa Ynez Mountains of the Transverse Ranges forearc has shifted north to its present position near the southern Sierra Nevada (Figure 1; Stauffer, 1967; Bottjer and Link, 1984; Dickinson et al., 1995).

\section{METHODS}

This study employed double-dating of detrital zircons, using the $\mathrm{U}-\mathrm{Pb}$ and $(\mathrm{U}-\mathrm{Th}) / \mathrm{He}$ methods (Rahl et al., 2003; Campbell et al., 2005; Reiners et al., 2005; Saylor et al., 2012), to recover the maximum depositional ages (Reiners et al., 2005), provenance (Rahl et al., 2003; Reiners et al., 2005; Campbell et al., 2005; Saylor et al., 2012), and depositional lag-time (Ruiz et al., 2004; Saylor et al., 2012 Michael et al., 2014) of Eocene forearc and trench-slope sediments in California. Zircon $\left(\mathrm{ZrSiO}_{4}\right)$ is a commonly used mineral for both $\mathrm{U}-\mathrm{Pb}$ geochronology and (U-Th)/He thermochronology due to its abundance in crustal rocks, necessary proportions of $\mathrm{U}, \mathrm{Pb}, \mathrm{Th}$, and $\mathrm{He}$ for measuring both decay systems, and stability and 
resistance to abrasion (Rahl et al., 2003; Reiners et al., 2005; Campbell et al., 2005; Saylor et al., 2012).

A key advantage of double dating is that the (U-Th)/He data can be paired with $\mathrm{U}-\mathrm{Pb}$ dates to distinguish first generation zircons from recycled grains, which has been a challenge for determining the maximum depositional age of a unit using $\mathrm{U}-\mathrm{Pb}$ ages alone, particularly where U-Pb ages are similar to a unit's depositional age (Reiners et al., 2005; Campbell et al., 2005; Saylor et al., 2012). Identification of first-generation (syndepositional) zircons is accomplished by calculating the difference in time between crystallization and when the zircon passes through its blocking temperature $\left(\sim 180-200^{\circ} \mathrm{C}\right.$ or $\sim 7-8 \mathrm{~km}$ depth assuming a $25^{\circ} \mathrm{C} / \mathrm{km}$ geotherm; Figure 2; House et al., 2001; Reiners, 2005; Wolfe and Stokli, 2010) (Figure 2; Rahl et al., 2003; Saylor et al., 2012). If the time between crystallization and cooling is within $2 \sigma$ of the (U-Th)/He age and ages overlap with the depostional age of the unit, then the grain is likely a first-generation zircon that can be considered for maximum depositional age estimates and excluded from further lag-time analysis (Saylor et al., 2012).

In addition to the identification of first-generation zircons, (U-Th)/He data can be used to calculate the depositional lag time, which is the difference between the zircon (U-Th)/He date (exhumation or cooling age) and its time of deposition (Figure 2; Garver et al., 1999; Bernet et al., 2001; Michael et al., 2014; Ruiz et al., 2004; Miller, 2012; Saylor et al., 2012). The lag-time is representative of the time between exhumation of zircon source regions to final deposition, and variations in these rates may indicate changes in source region exhumation over time. For example, zero lag time can be an indication of rapid exhumation and/or erosion of bedrock source regions from moderate crustal depths $(5-10 \mathrm{~km})$, whereas longer lag times $(10+\mathrm{Ma})$ may support more gradual erosion or temporary storage of sediment within a catchment (Figure 2; 
Garver et al., 1999; Bernet et al., 2001; Ruiz et al., 2004; Saylor et al., 2012; Michael et al., 2014). Negative lag times are generally considered to represent ZHe ages that are postdepositionally reset (Figure 2; Reiners et al., 2005). This conclusion is derived from the understanding that the $\mathrm{ZHe}$ age should not be younger than the depositional age of a sample.

\section{Sample collection and processing}

We collected 16 samples of Paleogene-age sandstones from 14 lithostratigraphic units from the Sierra Nevada foothills, Great Valley, and Coastal Ranges (Figure 2; Table 1). Most of the samples $(\mathrm{N}=14)$ were Eocene in age, but two samples (17SES-1 and 17SIM-1) were collected from late Eocene-Oligocene units with poorly constrained depositional ages. The samples were obtained from a large geographic area in order to test for any spatial trends in provenance and/or exhumation/cooling history. The sampled units and sites were selected on the basis of previous studies in the region (e.g., Jacobsen et al., 2011; Sharman et al., 2015) so that direct comparisons of $\mathrm{U}-\mathrm{Pb}$ age spectra could be made.

Each sample underwent standard mineral separation (mechanical, density, and magnetic separation) for zircon extraction using a jaw crusher and disk mill, GEMENI table, Frantz isodynamic magnetic separator, and heavy liquids (methylene iodide). After separation, 150 grains per sample were picked from sample splits under a binocular microscope. Previous statistical work has shown that $\sim 120$ grains are necessary to capture, within a $95 \%$ confidence level, all populations that comprise at least $5 \%$ of total age distribution (Vermeesch, 2004). Larger numbers of zircons ( 300 grains/sample) were picked for three samples, whose depositional ages were not well defined. Maximum depositional ages are notoriously difficult to obtain from detrital samples, and studies have shown $\sim 300$ grain analyses can capture age groups that comprise $\sim 1 \%$ of total age distribution within $95 \%$ confidence, and therefore increase the 
likelihood of capturing young grains that constrain maximum depositional ages ((Dickinson and Gehrels, 2009; Pullen et al., 2014)). Zircon grains of all morphologies and conditions (e.g., whole, cracked, rounded, euhedral, elongate, metamict, etc.) were picked for $\mathrm{U}-\mathrm{Pb}$ analysis to avoid biasing grain ages and missing important grain-age populations. Picked grains were then mounted onto $25 \mathrm{~mm}$ diameter epoxy pucks with double-sided tape (tape mount) and photographed and labeled for digital archive.

\section{Detrital zircon U-Pb geochronometry}

$\mathrm{U}-\mathrm{Pb}$ analysis of selected zircons was done using laser ablation-inductively coupled plasma mass spectrometry (LA-ICPMS) at the University of Kansas, Isotope Geochemistry Laboratory. Analyses were obtained on a Photon Machines Analyte.G2 193 nm ArF excimer laser ablation system coupled with a ThermoFinnigan Element2 ICPMS. $20 \mu \mathrm{m}$ circular spots were ablated with the laser set to $2.0 \mathrm{~J} \mathrm{~cm}^{-2}$ fluence and $10 \mathrm{~Hz}$ repetition rate, which resulted in $15 \mu \mathrm{m}$ pit depth. Analytical parameters can be found in Appendix 2. Analyses performed using the LA-ICPMS were calibrated against established zircon reference material GJ1, with a ${ }^{206} \mathrm{~Pb} /{ }^{238} \mathrm{U}$ age of $600.4 \pm 0.65 \mathrm{Ma}$ and a $608.5 \mathrm{Ma}{ }^{207} \mathrm{~Pb} /{ }^{206} \mathrm{~Pb}$ age, to address calibration drift and both downhole isotopic and elemental fractionation (Jackson et al., 2004). One GJ1 analysis was performed for every 5-8 unknowns throughout each sample run. Single GJ1 analyses typically produced ${ }^{206} \mathrm{~Pb} / 238 \mathrm{U}$ within $1-2 \%$ of the reported calibration age. Two secondary reference materials, the Plešovice and Fish Canyon Tuff zircons, were also used throughout each run for additional calibration (Appendix 3). During the course of this study, the Plešovice zircon reference yielded weighted mean ${ }^{206} \mathrm{~Pb} /{ }^{238} \mathrm{U}$ dates within $1-2 \%$ (range from $337.3 \pm 2.5-343.8 \pm$ 3.1 Ma) of the $337.13 \pm 0.37 \mathrm{Ma}$ age reported from CA-TIMS (chemical abrasion-thermal ionization mass spectrometry; Sláma et al., 2008). Similarly, the Fish Canyon Tuff zircon 
reference yielded weighted mean ${ }^{206} \mathrm{~Pb} /{ }^{238} \mathrm{U}$ ages within $1-2 \%$ (range from $28.1 \pm 0.4-29.1 \pm 0.4$ $\mathrm{Ma}$ ) of the reported ${ }^{206} \mathrm{~Pb} /{ }^{238} \mathrm{U}$ age of $28.402 \pm 0.023 \mathrm{Ma}$ (Smith and Bowring, 2001; Wotzlaw et al., 2013).

$\mathrm{U}-\mathrm{Pb}$ data reduction was performed using the open-source software package ET Redux (McLean et al., 2016). Grains with $<30 \%$ discordance and 5\% reverse discordance are reported and used for further interpretation, following procedures outlined by previous studies, which used similar methods within the study area (Cassel et al., 2012a and 2012b; Sharman et al., 2013). ${ }^{206} \mathrm{~Pb} /{ }^{238} \mathrm{U}$ ages were used for grains younger than $1.0 \mathrm{Ga}$ and ${ }^{207} \mathrm{~Pb} /{ }^{206} \mathrm{~Pb}$ ages were used for grains older than 1.0 Ga. U-Pb ages are reported with $2 \sigma$ errors and are shown in Appendix 4.

\section{Detrital zircon (U-Th)/He thermochronometry}

Zircon (U-Th)/He thermochronometry has previously been used in combination with U$\mathrm{Pb}$ geochronology in detrital provenance and source terrane cooling history studies (Campbell et al., 2005; Rahl et al., 2003; Rahl et al., 2007; Druschke et al., 2011). The (U-Th)/He system is fundamentally driven by the decay of ${ }^{238} \mathrm{U},{ }^{235} \mathrm{U}$, and ${ }^{232} \mathrm{Th}$ to ${ }^{4} \mathrm{He}$ via alpha decay (Farley et al., 1996). However, retention of the daughter isotope is temperature dependent, with thermally activated volume diffusion of the ${ }^{4} \mathrm{He}$ occurring over $\sim 130-210^{\circ} \mathrm{C}$, defining the zircon helium partial retention zone (Reiners et al, 2002; Reiners et al., 2004; Wolfe and Stockli, 2010). Other factors like grain size (Farley, 1996; Reiners et al., 2004), parent isotope zonation (Farley et al., 1996; Reiners et al., 2004; Hourigan et al., 2005; Reiners, 2005; Dobson et al., 2008), and radiation damage (Nasdala et al., 2004; Reiners et al., 2004; Reiners, 2005; Guenther et al., 2013) also play significant roles in ${ }^{4} \mathrm{He}$ retention and (U-Th)/He results. An additional complication for $(\mathrm{U}-\mathrm{Th}) / \mathrm{He}$ dating is the ejection or loss of ${ }^{4} \mathrm{He}$ near grain margins during decay, which requires a morphometric 'Ft' age correction (Farley et al., 1996; Farley, 2002). 
Zircons selected for (U-Th)/He analysis were evaluated, measured, and photographed using a binocular microscope with mounted digital camera. Grain selection was based on grain morphology and condition, with ideal grains being large ( $>70 \mu \mathrm{m}$ grain width; Farley et al., 1996; Reiners et al., 2004; Reiners, 2005), euhedral (Farley et al., 1996; Farley, 2002; Reiners, 2005) and clear and free of inclusions, defects, and evidence of radiation damage (i.e., not metamict; Nasdala et al., 2004; Hourigan et al., 2005; Reiners, 2005). These criteria minimize errors resulting from fast diffusion pathways, inhomogeneous parent distributions, and the alphaejection (Ft) correction (Farley et al., 1996; Farley, 2000; Reiners, 2005). Using this approach, 5-15 grains were ultimately picked from the tape mounts for each sample.

(U-Th)/He analyses were performed at the University of Texas at Austin (U-Th)/He Thermochronometry Lab. Zircons selected for analysis were individually packed into 1-mm Pt foil tubes and laser heated (using a $20 \mathrm{~W} \mathrm{Nd:YAG} \mathrm{laser)} \mathrm{for} 10$ minutes at $1300^{\circ} \mathrm{C}$. Grains were reheated to ensure complete degassing (to $<1 \%$ ). The extracted He gas was then spiked with ${ }^{3} \mathrm{He}$ and cryogenically purified. The spiked and purified gas was then measured on a quadrupole noble gas mass spectrometer. The degassed zircons were then removed from the Pt packets and dissolved using standard Parr pressure vessel 2-stage digestion procedures $\left(\mathrm{HF}-\mathrm{HNO}_{3}\right.$ and $\left.\mathrm{HCl}\right)$. Dissolved samples were then spiked with ${ }^{230} \mathrm{Th},{ }^{235} \mathrm{U}$, and ${ }^{149} \mathrm{Sm}$ and analyzed on a ThermoFinnigan Element2 ICPMS for U, Th, and Sm. After analysis, an 'Ft' correction was applied to dates to account for alpha ejection near grain margins (Farley et al., 1996; Farley 2002). For each date, an $8 \%(2 \sigma)$ standard uncertainty is applied to the grain's date based on the reproducibility of the Fish Canyon Tuff zircon laboratory standard (Reiners and Farley, 2001; Schmitz and Bowring, 2001; Reiners et al., 2002).

\section{Age data analysis and visualization}


The U-Pb and (U-Th)/He age data are plotted in several different ways. Kernel Density Estimation (KDE) plots, which discretize the data by summing stacked Gaussian distributions as a means of representing the frequency of various ages in detrital datasets, were produced via DensityPlotter (Vermeesch, 2012; Vermeesch et al., 2016). We also use Multi-Dimensional Scaling (MDS) plots, which are a more quantitative way of comparing samples using measured 'dissimilarities' between age spectra, constructed using the R package Provenance (Vermeesch, 2013, Vermeesch et al., 2016). Concordia diagrams were produced using ET Redux (McLean et al., 2016). For depositional lag-time analysis, we plot zircon (U-Th)/He ages against bestestimated depositional ages for each sample (Figures 10a/b; Michael et al., 2014; Ruiz et al., 2004; Miller, 2012; Saylor et al., 2012). U-Pb versus (U-Th)/He plots, which reflect the time between zircon crystallization and exhumation above the zircon (U-Th)/He PRZ, are also provided in order to observe any He-Pb correlations (Figures 11a/b; Reiners et al., 2005; Campbell et al., 2005).

\section{RESULTS}

\section{Zircon U-Pb age populations}

Of the 2,163 detrital zircons analyzed, 1,899 grains yielded concordant ages (within the limits outlined above), with $\mathrm{U}-\mathrm{Pb}$ ages ranging from $\sim 37$ to $2600 \mathrm{Ma}$. To facilitate comparison of our results with datasets of Jacobsen et al. (2011) and Sharman et al. (2015), we report detrital zircon $\mathrm{U}-\mathrm{Pb}$ ages in the context of previously published age bins as shown in Table 2: $>300 \mathrm{Ma}$, 200-135 Ma (Jurassic), 135-85 Ma (Cretaceous), 85-65 Ma (latest Cretaceous), and <65 Ma (Paleogene). U-Pb analytical parameters, standards and reference material information, and the full suite of isotopic measurements, interpreted ages, and Concordia diagrams are provided in Appendix 4. U-Pb KDE diagrams are displayed in Figure 3 and $\mathrm{U}-\mathrm{Pb}$ age populations shown as 
pie charts are provided in Figure 4.

\section{General trends}

Major age peaks, although variable in prominence for each sample, cluster around $~ 1400$ and $1700 \mathrm{Ma}$, the Jurassic (200-135 Ma), the early (135-100 Ma) and late (100-85 Ma) midCretaceous, and latest Cretaceous (85-65 Ma). A few samples also produced 1100 Ma zircon ages (Figure 4). In general, samples do not contain significant numbers of Paleogene ( $<65 \mathrm{Ma})$ grains, with the exception of one Markley Sandstone sample (15VC02), which has the largest number of grains in this age bin (23\%). Likewise, most samples contain few Permian-Triassic grains (maximum of 11\%; sample 15SP01).

Spatial trends are also clear in the data, with samples collected in the northern and central parts of the study area (e.g. Salinian block and Great Valley) containing few, if any, >300 Ma age zircons; whereas, samples from the Sierra Madre and Santa Ynez Mountains, in the southern part of the study area, produced large numbers of $>300$ Ma grains (up to 64\% of the total;

Figures 4 and 5). The southern samples also contained significant Jurassic and latest Cretaceous populations, and fewer mid-Cretaceous-age zircons. By comparison, samples from the northern part of the study area, with the exceptions of the Butano (17BUT-1) and Markley (15VC02) sandstones, contained the largest numbers of mid-Cretaceous grains and generally fewer Jurassic zircons. Based on these trends, the samples are arranged into five geographic groups, shown in Figure 5, based on the geographic proximity and similarities in $\mathrm{U}-\mathrm{Pb}$ age data.

\section{Sample results}

17BUT-1 is from the early Eocene Butano Sandstone that yielded 223 concordant U-Pb ages (Table 1; Figure 1). Most (95\%) of the ages were <300 Ma, with Jurassic ages (200-135 
Ma) constituting $56 \%$ of the grain ages, the largest Jurassic population of all samples, followed by significant early mid-Cretaceous (135-100 Ma; 17\%) and late mid-Cretaceous (100-85 Ma; $18 \%$ ) age groups (Figure 4). A small number of late Cretaceous (3\%) and Permian-Triassic (2\%) zircons are also present and 5\% of the sample yielded ages $>300 \mathrm{Ma}$, primarily clustering around $\sim 1400$ and $1700 \mathrm{Ma}$ (Figures $3 \&$ 4). No Cenozoic (<65 Ma) grains were revealed.

Sample 17GS-1 yielded 87 concordant U-Pb ages from the early Eocene Greystone Fm. (Table 1; Figure 1). The majority of grains (52\%) are early mid-Cretaceous (135-100 Ma) and $27 \%$ are late mid-Cretaceous (100-85 Ma) and constitute the major age peak displayed in the KDE plot (Figures $3 \& 4$ ). The remaining grains are mostly Jurassic (200-135 Ma; 18\%) and display as a secondary, subdued peak in the KDE diagram (Figures $3 \& 4$ ). Only one late Cretaceous age (100-85 Ma) was identified $(78.1 \pm 2.8 \mathrm{Ma})$ and one $>300$ Ma grain $(1194.4 \pm$ 96.5 Ma). No Permian-Triassic or Paleogene-age zircons were revealed.

Sample 15SP01 was collected from the early Eocene German Rancho Formation (Table 1; Figure 1). U-Pb analysis yielded 82 concordant ages. The vast majority (96\%) of the U-Pb ages are $<300 \mathrm{Ma}$, with significant age peaks, as seen in the KDE plot, in the Jurassic (200-135 Ma; 25\%) and early mid-Cretaceous (135-85 Ma; 59\%; Figures 3 \& 4). A smaller peak, between 200-300 Ma, is also reflected in the KDE plot that constitutes $11 \%$ of the total grain-ages (Figures $3 \& 4$ ). Only two grains yielded latest Cretaceous ages $(80.9 \pm 4.4 \mathrm{Ma} ; 84.2 \pm 8.9 \mathrm{Ma})$ and no Cenozoic ( $<65 \mathrm{Ma}$ ) ages were obtained. Grains $>300$ Ma comprise the remaining $4 \%$ of the sample $(1050.6 \pm 57.6 \mathrm{Ma} ; 1683.3 \pm 41.8 \mathrm{Ma} ; 1835.5 \pm 81.0$; Figure 4).

Samples 15VC01 and 15VC02 are considered to be from the same unit, the Markley Fm. (Fulmer, 1956; Milam, 1985), which has a middle Eocene age (Table 1; Figure 1). Sample 15VC01 yielded 114 concordant ages, with major age peaks in the Jurassic (200-135 Ma; 29\%) 
and mid-Cretaceous (135-85 Ma; 65\%; Figures $3 \& 4$ ). Smaller grain populations include one $>300 \mathrm{Ma}$ age $(1733.9 \pm 134.3 \mathrm{Ma})$, three grains of Eocene age $(48.5 \pm 4.5 \mathrm{Ma} ; 50.4 \pm 1.9$ Ma; $53.8 \pm 2.2 \mathrm{Ma})$, two latest Cretaceous ages $(75.5 \pm 3.1 \mathrm{Ma} ; 78.0 \pm 5.8 \mathrm{Ma})$, and two Triassic ages $(218.2 \pm 6.6 \mathrm{Ma} ; 249.6 \pm 8.3 \mathrm{Ma})$. In comparison, sample 15VC02 returned significantly different results based on 85 concordant ages (Figures $3 \& 4$ ). A significant $>300$ Ma age population (18\% of the grains analyzed) is present, clustering around $\sim 1400$ and $1700 \mathrm{Ma}$ and containing two older U-Pb ages (1832.4 \pm 83.3 Ma; 2598.6 \pm 84.1 Ma; Figures $3 \& 4)$. Five notable age peaks younger than $300 \mathrm{Ma}$ are also apparent in the KDE plot: $13 \%$ Jurassic ages (200-135 Ma), 18\% of early mid-Cretaceous ages (135-100 Ma), 11\% late mid-Cretaceous ages (100-85), $14 \%$ of latest Cretaceous ages (85-65 Ma), and 27\% of Paleogene ages (<65 Ma), where the primary age peaks are early mid-Cretaceous (135-100 Ma) and latest Cretaceous (85$65 \mathrm{Ma}$; Figures $3 \& 4)$. Similar to $15 \mathrm{VC} 01$, this sample only yielded three Triassic ages $(203.0 \pm$ 9.3 Ma; $223.7 \pm 26.5 \mathrm{Ma} ; 223.8 \pm 8.1 \mathrm{Ma})$.

17IONF-2 is from the middle Eocene Ione Fm. and yielded 238 concordant ages (Table 1; Figure 1). Grain ages are distributed trimodally (Figure 3). The majority of the reported ages are early mid-Cretaceous (135-100 Ma; 38\%) and late mid-Cretaceous (100-85 Ma; 31\%) where each composes a peak on the KDE diagram (Figures 3 \& 4). A significant Jurassic (200-135 Ma) population is also present $(27 \%)$ as a broad peak (Figures $3 \& 4$ ). Only two grains yielded ages >300 Ma (1027.5 $\pm 108.9 \mathrm{Ma} ; 1845.0 \pm 101.7 \mathrm{Ma})$ and 3\% of the sample yielded latest Cretaceous ages (85-65 Ma; Figure 4). Two grains yielded Eocene ages (47.9 $\pm 3.5 \mathrm{Ma} ; 50.2 \pm$ 2.5 Ma) and two grains also yielded Triassic ages $(219.7 \pm 7.7 \mathrm{Ma} ; 243.3 \pm 8.4 \mathrm{Ma})$.

Early Eocene samples 15MD01 and 15MD02 were both taken from the Meganos Fm. in the Mt. Diablo region (Table 1; Figure 1). Both samples have age distributions made up of two 
peaks: a smaller Jurassic (200-135 Ma) and a primary mid-Cretaceous (135-85 Ma) grain ages (Figures 3 \& 4). Sample 15MD01 produced 88 concordant grains, composed of Jurassic (21\%), early mid-Cretaceous (135-100 Ma; 63\%), and late mid-Cretaceous (100-85 Ma; 15\%; Figures 3 \& 4). One grain of Triassic age $(207.2 \pm 6.9 \mathrm{Ma})$ is also present. No grains with Paleogene, latest Cretaceous, or >300 Ma ages were found in 15MD01. 15MD02 yielded 113 concordant grains, with $99 \%$ of the grains <300 Ma in age (Figure 4). Major age groups include Jurassic (200-135 Ma; 28\%), early mid-Cretaceous (135-100 Ma; 44\%), and late mid-Cretaceous (100-85 Ma; $26 \%$; Figures $3 \& 4)$. Only one grain of latest Cretaceous age $(82.7 \pm 9.3 \mathrm{Ma})$ was revealed. Unlike 15MD01, sample 15MD02 differs in that it produced one <65 Ma grain age $(44.0 \pm 5.3$ $\mathrm{Ma})$, one grain with >300 Ma ages $(1452.4 \pm 62.0 \mathrm{Ma})$ and lacks Permian or Triassic grains.

17TES-1 was collected from the late Paleocene-early Eocene Tesla Fm. and yielded a total of 108 concordant U-Pb ages (Table 1; Figure 1). Most (99\%) of the grains yielded $<300$ Ma ages, composed of two age peaks-- a smaller Jurassic peak (200-135 Ma; 25\%) and a larger peak consisting of both early mid-Cretaceous (135-100 Ma; 55\%) and late mid-Cretaceous (100$85 \mathrm{Ma} ; 15 \%$ ) ages (Figures $3 \& 4)$. Only one grain yielded an age >300 Ma (423.6 $\pm 12.3 \mathrm{Ma})$, and two grains yielded Triassic ages $(217.6 \pm 6.4 \mathrm{Ma} ; 243.4 \pm 6.6 \mathrm{Ma})$. Two grains of latest Cretaceous age (85-65 Ma) are also present $(71.7 \pm 2.8 \mathrm{Ma} ; 76.6 \pm 3.7 \mathrm{Ma})$ and no $<65 \mathrm{Ma}$ grains were revealed.

17POR-1a, from the middle Eocene Point of Rocks Sandstone in the southern part of the Great Valley, yielded 216 concordant U-Pb grain ages (Table 1; Figure 1). The majority (99\%) of the zircons are <300 Ma (Figure 4). Early mid-Cretaceous (135-100 Ma; 54\%) and late midCretaceous (100-85 Ma; 23\%) ages comprise the prominent peak in the KDE diagram (Figures 3 \& 4). A less pronounced Jurassic (200-135 Ma) peak is also present, comprising $17 \%$ dated 
grains (Figures $3 \& 4$ ). Paleogene ( $<65 \mathrm{Ma}$ ) grains comprise $2 \%$ of the data (Figure 4). Only two Proterozoic ages $(1395.3 \pm 46.2 \mathrm{Ma} ; 1518.4 \pm 50.2 \mathrm{Ma})$ and one Triassic $(221.6 \pm 13.8 \mathrm{Ma})$ age are reported for this sample.

A major shift in proportions of zircon ages occurs in the southernmost samples, most notably a significant increase in numbers of $>300$ Ma ages (Figure 4). Sample 17TSSG-1, from an early Eocene unnamed sandstone in the Sierra Madre (Table 1; Figure 1), had 86 concordant $\mathrm{U}-\mathrm{Pb}$ ages made up of four major grain populations, split between Proterozoic and $<300 \mathrm{Ma}$ age groups (Figure 3 ). The majority (39\%) of the ages are $>300 \mathrm{Ma}$ and cluster around $\sim 1400$ and $1700 \mathrm{Ma}$ (Figures 3 \& 4). Another 33\% of the grains yielded Jurassic (200-135 Ma) ages that make up one of the main $<1$ Ga peaks on the KDE diagram (Figure 4). A significant late midCretaceous (100-85 Ma; 6\%) to latest Cretaceous (85-65 Ma; 14\%) peak is also present (Figures $3 \& 4$ ). Permian-Triassic ages make up $7 \%$ of grain-ages in this sample (Figure 4). Only one early mid-Cretaceous (135-100 Ma) grain was revealed (129.9 $\pm 6.9 \mathrm{Ma})$ and no Paleogene $(<65$ Ma) grains.

Sample 17SIM-1, from the late Eocene-early Oligocene Simmler Fm. in the Cuyama Valley (Table 1; Figure 1), yielded $\mathrm{n}=113 / 117$ concordant $\mathrm{U}-\mathrm{Pb}$ ages. Similar to sample 17TSSG-1, 20\% of the zircons are $>300$ Ma ages clustering around $\sim 1400$ and 1700 Ma (Figure $3 \& 4$ ). The next most prominent age groups are Jurassic (200-135 Ma; 33\%), late midCretaceous (100-85 Ma; 24\%), and latest Cretaceous (85-65 Ma; 9\%; Figure 3). These ages groups form a bimodal age distribution, with a primary Jurassic peak and a secondary late midCretaceous to latest Cretaceous peak (100-65 Ma; Figure 3). There is also a paucity of early midCretaceous grain ages (135-100 Ma; 5\%; Figure 4) in the sample. Permian-Triassic ages comprise $9 \%$ of the zircons analyzed and no grains $<65$ Ma were obtained (Figure 4). 
The southernmost samples in this study were collected from a transect through early Eocene to early Oligocene units in the Santa Ynez Mountains (Table 1; Figure 1). The stratigraphically lowest sample, 17JUN-2, obtained from the early Eocene Juncal Fm., yielded 101 concordant $\mathrm{U}-\mathrm{Pb}$ ages, of which $16 \%$ were $>300 \mathrm{Ma}$, most of which cluster around $\sim 1400$ and $1700 \mathrm{Ma}$ (Table 1; Figures $3 \& 4$ ). Of the $>300$ Ma ages, two were middle Paleozoic (341.8 $\pm 16.5 \mathrm{Ma} ; 381.5 \pm 15.0 \mathrm{Ma})$. The majority of the analyzed grains $(69 \%)$ are early midCretaceous (135-100 Ma; 24\%), late mid-Cretaceous (100-85 Ma; 23\%), and latest Cretaceous (85-65 Ma; 22\%), and display as the major age peak on the KDE plot (Figures $3 \& 4$ ). Only $13 \%$ of the zircons are Jurassic (200-135 Ma) in age and are represented as a subdued peak (Figures 3 \& 4). Two Paleogene grains are reported $(48.1 \pm 3.5 \mathrm{Ma} ; 56.2 \pm 5.3 \mathrm{Ma})$.

Sample 17MAT-1, from the middle Eocene Matilija Sandstone, in the Santa Ynez Mountains section (Table 1; Figure 1), yielded 93 concordant U-Pb ages, with grain-age proportions differing from 17JUN-2. Cretaceous, Jurassic, and >300 Ma age groups comprise the majority of the sample's age distribution (Figure 4). Most notably, $48 \%$ of the sample is $>300$ Ma, with three dominant age peaks at $\sim 1100,1400$, and $1700 \mathrm{Ma}$ (Figures $3 \&$ 4). Jurassic (200$135 \mathrm{Ma} ; 25 \%$ ) and Cretaceous (135-100 Ma-3\%; 100-85 Ma-2\%; 85-65 Ma-18\%) age populations are also apparent as bimodal age peaks on the KDE (Figures $3 \& 4$ ). $4 \%$ of the sample yielded Triassic ages and no Paleogene (<65 Ma) zircons were recovered (Figure 3).

The late Eocene Coldwater Sandstone sample, 17CWSS-2, also comes from the Santa Ynez Mountains section and yielded 98 concordant U-Pb ages (Table 1; Figure 1). Sample 17CWSS-2 is mainly composed of >300 Ma (61\%), Jurassic (200-135 Ma; 17\%), late midCretaceous (100-85 Ma; 9\%), and latest Cretaceous (85-65 Ma; 9\%; Figure 4). A small (3\%) population of early mid-Cretaceous ages is also present (135-100 Ma; Figure 4). The >300 Ma 
ages cluster at $\sim 1400$ and $1700 \mathrm{Ma}$, with the $\sim 1400$ Ma peak being the most prominent (Figure 3). Grains with <300 Ma ages present as trimodal age peaks, with Jurassic (200-135 Ma), midCretaceous (135-185 Ma), and latest Cretaceous age (85-65 Ma) peaks (Figure 3). No Paleogene or Permian-Triassic grains were captured.

Lastly, 17SES-1 represents the latest Eocene to Oligocene Sespe Fm. in the Santa Ynez Mountains, and yielded 109 concordant $\mathrm{U}-\mathrm{Pb}$ ages (Table 1; Figure 1). The majority of grains within the sample $(60 \%)$ are $>300 \mathrm{Ma}$, with clusters around $\sim 1400$ and $1700 \mathrm{Ma}$ (Figures $3 \& 4$ ). The next major age population is Jurassic (200-135 Ma; 25\%) and constitutes the major <300 Ma peak (Figures $3 \& 4$ ). Considerably fewer Cretaceous grains were recovered compared with the other samples analyzed. Of the Cretaceous grains, 6\% yielded early mid-Cretaceous ages (135$100 \mathrm{Ma}$ ), only $2 \%$ yielded late mid-Cretaceous ages (100-85 Ma), and 6\% yielded latest Cretaceous ages (85-65 Ma), which are present as a small, but slightly bimodal age peak on the KDE diagram (Figures $3 \& 4)$. Two Triassic grains (217.2 $\pm 10.5 \mathrm{Ma} ; 21.2 \pm 10.2 \mathrm{Ma})$ and one latest Eocene grain $(36.9 \pm 3.2 \mathrm{Ma})$ were also identified.

\section{Maximum depositional ages}

Seven of the sixteen samples analyzed in this study contain Cenozoic (young) zircons that can be used to approximate the maximum depositional age (MDA) of the sampled units (Dickinson and Gehrels, 2009; Table 3). Although multiple methods for determining MDAs have been proposed, we provide both the weighted mean of the youngest age population (ideally three or more zircons that overlap within $2 \sigma$ where available) and the single youngest grain U-Pb age for each sample (Table 3; Dickinson and Gehrels, 2009). Identifying young grains whose ages overlap at the $1 \sigma$ or $2 \sigma$ level was a challenge for several of our samples, and only five of the seven had more than one young detrital zircon age. 
In general, maximum depositional ages reported in Table 3 overlap with and confirm published age estimates for the sampled units (Tables 1 and 3). Single-grain age constraints are within a few million years of the formation ages outlined in Table 1. However, comparison of the mean and single-grain ages shows the mean ages are generally older than the single-grain maximum depositional ages, a finding that is in line with conclusions from Dickinson and Gehrels (2009). Maximum depositional age constraints are outlined in Table 3 and described in detail below.

The upper Markley Sandstone (15VC02) contains the largest number of Eocene grains $(\mathrm{n}=19)$, with single-grain $(42.8 \pm 2.4 \mathrm{Ma})$ and mean maximum depositional ages $(45.2 \pm 1.1 \mathrm{Ma})$ that overlap with the published depositional age range (41.5-36.9 Ma) based on lithologic correlations of Milam (1985) (Tables $1 \& 3$ ). By comparison, the lower Markley Sandstone (15VC01) sample contains only three young grain ages, with both single grain $(48.5 \pm 4.5 \mathrm{Ma})$ and weighted mean $(51.5 \pm 1.4 \mathrm{Ma})$ maximum depositional ages that are slightly older than the 41.5 to 36.9 Ma assigned depositional age range (Milam, 1985; Tables $1 \&$ 3). Dumitru et al. (2013) identified young grains that were similar in age to ours, but only for the lower Markley Sandstone. The upper Meganos Formation (15MD02) produced one Eocene grain-age (44.0 \pm 5.3 Ma) that overlaps within error with the 56 to $47.8 \mathrm{Ma}$ age range of the unit (Cherven, 1983; Table 3).

Of the three samples with large populations $(\mathrm{n} \approx 250)$ of detrital zircon ages (Butano Sandstone, Ione Formation, and Point of Rocks Sandstone), only the Point of Rocks Sandstone and Ione Formation revealed two young grains (Table 3). The Ione Formation (17IONF-2) produced identical (i.e., within uncertainty) single-grain $(47.9 \pm 3.5 \mathrm{Ma})$ and mean maximum depositional ages (49.4 $\pm 2.0 \mathrm{Ma}$ ) that overlap with its 47 to $40.5 \mathrm{Ma}$ age assignment (Creely and 
Force, 2007; Tables $1 \& 3$ ). However, published detrital zircon ages for the Ione record younger maximum depositional ages between $43.6 \pm 2.6$ and $44.1 \pm 1.5 \mathrm{Ma}$ (Sharman et al., 2015). Our sample was collected from the base of the formation, atop the Jurassic-age basement, and thus may reflect a portion of the formation that is slightly older than previous estimates. The Point of Rocks Sandstone (17POR-1a) also revealed similar single-grain (46.7 $\pm 1.6 \mathrm{Ma})$ and mean maximum depositional ages $(47.1 \pm 1.2 \mathrm{Ma})$, both of which are consistent with the 48 to $37 \mathrm{Ma}$ depositional age assignment (Nilsen and Clarke, 1975; Table 3). This study's youngest zircon U$\mathrm{Pb}$ ages reasonably match results from a previous study with middle Eocene zircon ages (Sharman et al., 2013/2015).

The Butano Sandstone sample (17BUT-1) does not contain any Cenozoic zircons, despite the large number of grains analyzed, suggesting one of two things: (1) the unit did not receive Eocene detritus from source regions, possibly an important detail about its depositional history or (2) laboratory biases during mineral separation could have affected results (Pullen et al., 2014). Although we cannot rule out biases during mineral separation, we favor the former because neither of the other Salinian Block samples we analyzed contain significant populations of young zircon (e.g. 17GS-1; 15SP01), a result that is similar to Sharman et al. (2013). Therefore, it seems plausible that these locations, in their original depositional position, were not receiving detritus from Eocene sources.

For the Sespe Formation (17SES-1), we recovered a single $36.9 \pm 3.2$ Ma grain that is consistent with published 38 to 33 Ma age estimates based on stratigraphic relationships described by Howard (1995) (Tables $1 \&$ 3). This sample, from the Santa Ynez Mountains transect, helps to constrain the Eocene stratigraphic succession at this locale and maximum depositional age for this unit. The three samples from the Santa Ynez Mountains were assigned 
depositional ages based on the presence of benthic foraminiferaand other fossils found in each unit (Vedder, 1972; Nilsen and Clarke, 1975; Thompson, 1988). The Juncal Formation (17JUN2), considered 56 to $47.8 \mathrm{Ma}$ old (Nilsen and Clarke, 1975; Thompson, 1988), produced a $48.1 \pm$ 3.5 Ma single grain maximum depositional age and a 50.5 \pm 2.9 Ma mean maximum depositional age, based on two grain ages. Both of these overlap with the estimated depositional age of the unit (Table 3). The Coldwater (17CWSS-2) and Matilija (17MAT-1) sandstone samples do not contain grains suitable for maximum depositional age analysis (Table 3). Young grains may have been missed due to the number of grains analyzed $(n=102-106)$ for these samples. However, this result is consistent with the limited number of Eocene zircon found in other samples from the same transect and with previous detrital studies, which also lacked Eocene-age zircons for this unit (Jacobsen et al., 2011; Table 3).

\section{Zircon (U-Th)/He populations}

We obtained 159 new zircon (U-Th)/He (ZHe) ages from our samples (Appendix 5). The analyzed grains were selected from major peaks in the $\mathrm{U}-\mathrm{Pb}$ age spectra for each sample, resulting in 4-15 single-grain ZHe ages per sample (Figure 6). Although larger grain populations are desirable for detrital thermochronology (Rahl et al., 2003, Campbell et al., 2005; Reiners et al., 2005), many grains were disqualified from (U-Th)/He analysis due to their morphology and/or condition. The low number of grains per sample means that the potential for missed age populations is high (Vermeesch, 2004, Andersen, 2005), particularly for (U-Th)/He dates, which are dependent on cooling rate and likely to be more variable than crystallization ages. ZHe dates were evaluated for grain size (e.g., Reiners and Farley, 2001; Reiners et al., 2004) and radiation damage effects (e.g., Nasdala et al., 2004; Reiners et al., 2004), which are known to influence (U-Th)/He ages. No grain size versus date relationships were recognized, and although our 
analyzed grains had a wide range of $\mathrm{e}[\mathrm{U}]$ concentrations, between 10-1200 ppm, no obvious correlations with dates were observed (Figure 7). In the following section, we first aggregate ZHe dates to evaluate major cooling-age trends across our samples. We then group the results by major $\mathrm{U}-\mathrm{Pb}$-age bins and by geography.

Overall, the dataset shows a wide range in cooling ages, from 205 and $24 \mathrm{Ma}$. The majority of ages group between $\sim 88$ to $40 \mathrm{Ma}$ ( $85 \%$ of ZHe dates) with a peak at $64.7 \mathrm{Ma}$. Most (53\%) of the cooling ages reported in Appendix 5 are Cenozoic ( $<65 \mathrm{Ma}$ ), with $\sim 5 \%$ of grains Oligocene $($ mean age $=31.0 \mathrm{Ma}), \sim 27 \%$ of Eocene age $($ mean age $=47.8 \mathrm{Ma})$, and $\sim 19 \%$ of Paleocene age (mean age $=61.1 \mathrm{Ma})$. The next largest group of ages $(42 \%)$ are late Cretaceous (90-65 Ma), with a mean date of 74.3 Ma. There is also a small group ( 6\%) of midCretaceous (125-100 Ma) grain-ages, with a mean ZHe date of 111.3 Ma. One Triassic cooling date (Sample 17SIM-1, $205.8 \pm$ 16.5 Ma) was also recorded (Appendix 5).

Another instructive way to report the data is by $\mathrm{U}-\mathrm{Pb}$-age groups or bins, which can help illustrate the cooling history of potential sediment sources. Most age bins preserve latest Cretaceous and Eocene cooling peaks (Figure 6). Cenozoic zircons (U-Pb age: 37-56 Ma; n=6) reveal $\mathrm{ZHe}$ ages that range from $\sim 27$ to $49 \mathrm{Ma}$, with $33 \%$ of these grains recording Oligocene dates and 66\% Eocene ages (Figure 6). Latest Cretaceous zircons (U-Pb age: $85-65 \mathrm{Ma}$; $\mathrm{n}=13$ ) range in cooling ages from $\sim 30$ to $67 \mathrm{Ma}$, with $\sim 23 \%$ recording Oligocene, $\sim 38 \%$ Eocene, $\sim 31 \%$ Paleocene, and $\sim 8 \%$ Late Cretaceous (Figure 6). ZHe ages for late mid-Cretaceous zircons (U-Pb age: $100-85 \mathrm{Ma} ; \mathrm{n}=18$ ) range from $\sim 30$ to $81 \mathrm{Ma}$, with $\sim 6 \%$ of the grains recording Oligocene, $\sim 22 \%$ Eocene, $\sim 33 \%$ Paleocene, and $\sim 39 \%$ late Cretaceous (Figure 6). Comparatively, early mid-Cretaceous zircons (U-Pb age: $135-100 \mathrm{Ma} ; \mathrm{n}=22$ ) record similar proportions of Eocene ages $(\sim 18 \%)$, significantly fewer Paleocene $(\sim 9 \%)$, and a large number of Cretaceous ZHe ages 
( 73\%; Figure 6). The majority $(81 \%, \mathrm{n}=13 / 16)$ of Cretaceous ZHe ages for this U-Pb-age bin are latest Cretaceous (U-Pb age: 85-65 Ma) (Figure 6). Jurassic zircons (U-Pb age: 200-135 Ma; $\mathrm{n}=36$ ) range from $\sim 40$ to $112 \mathrm{Ma}$, with $25 \%$ of reported ZHe ages being Eocene, $\sim 19 \%$ Paleocene, and 56\% Cretaceous (also dominantly late Cretaceous: n=15/20; Figure 6). PermianTriassic zircons (U-Pb age: 300-200 Ma; $\mathrm{n}=21$ ) preserve no Eocene and only one Triassic and mid-Cretaceous cooling age each. This $\mathrm{U}-\mathrm{Pb}$ bin is dominated by Paleocene ( $38 \%)$ and late Cretaceous ( 52\%) cooling ages (Figure 6). Zircons with U-Pb ages $>300 \mathrm{Ma}(\mathrm{U}-\mathrm{Pb}$ age: 300 450 \& 1000-2600 Ma; $n=34)$ have ZHe dates that are mostly Eocene $(\sim 38 \%)$ and Cretaceous ( $47 \%$; dominantly latest Cretaceous), with smaller numbers of Oligocene (6\%) and Paleocene (9\%) ages (Figure 6). The three Paleozoic grains, with U-Pb ages between 300 to $450 \mathrm{Ma}$, all record mid-Cretaceous cooling ages of $\sim 105-125$ Ma (Figure 6). Precambrian grains include three significant age bins, $\sim 1100 \mathrm{Ma}, \sim 1400 \mathrm{Ma}$, and $\sim 1700 \mathrm{Ma}$, that all record bimodal cooling in the latest Cretaceous-Paleocene ( 63-76 Ma) and Eocene ( 50-53 Ma; Figure 6).

The ZHe ages can also be evaluated as geographic groups based on sample locations, shown in Figure 5. Sample groups were established from palinspastic reconstructions by Sharman et al. (2015) and from relationships observed in the U-Pb data (Figure 5). ZHe ages display spatial trends from north to south. Northern samples generally display single, primary cooling age peaks in the Cretaceous through Paleogene versus southern samples which tend to record multiple, distinct age peaks, split between the Cretaceous and Paleogene (Figure 6). Samples from both the Santa Ynez Mountains and Vacaville areas (Figure 3) are considered ineligible for further $\mathrm{ZHe}$ analysis based on the presence of reset ages. Resetting in both sample locations is likely caused by post-depositional burial of the samples and, therefore, $\mathrm{ZHe}$ ages are unreliable and do not further source region exhumation analysis. 
The largest sample group in the dataset, the Great Valley group (Figures 5 \& 8), records ZHe ages ranging from $\sim 108$ to $51 \mathrm{Ma}(\mathrm{n}=34)$. This sample group largely contains latest Cretaceous ages ( 68\%), with lesser numbers of Eocene $(\sim 6 \%)$, Paleocene $(\sim 15 \%)$ and midCretaceous ages ( 6\%). Great Valley samples primarily record continuous latest Cretaceousearly Paleogene cooling, with age peaks ranging from $\sim 72$ to $65 \mathrm{Ma}$ and smaller peaks at $\sim 82 \mathrm{Ma}$ and $58 \mathrm{Ma}$ (Figures $8 \&$ 9). The Point of Rocks Sandstone, which is deposited the furthest south in the Great Valley group, diverges from this trend and only records late Cretaceous cooling (Figures 8 \& 9). Samples from the Salinian Block ( $n=29$; Figure 5), which are now translated north of their original depositional location (Sharman et al., 2015), record ZHe dates from $\sim 51$ to $108 \mathrm{Ma}$, made up of $\sim 10 \%$ Eocene, $\sim 41 \%$ Paleocene, $\sim 35 \%$ late Cretaceous, and $\sim 14 \%$ midCretaceous grain-ages. Both the Butano Sandstone and German Rancho Fm. samples record a single late Cretaceous to Eocene (between 90 and $51 \mathrm{Ma}$ ) cooling date peak, whereas the Greystone Fm. sample records separate late Cretaceous ( 87 Ma) and Paleogene ( 62 Ma) cooling (Figures $8 \& 9$ ). Collectively, these samples document primary cooling at $\sim 62 \mathrm{Ma}$ and a less prominent cooling at $\sim 82 \mathrm{Ma}$. Samples from the Sierra Madre (n=23; Figure 5) record multiple age peaks in their KDE diagrams and also containthe most widely dispersed ZHe dates between $\sim 49$ to $206 \mathrm{Ma}$ (Figure 8). Of the ZHe ages, $4 \%$ are Eocene, $22 \%$ are Paleocene, $\sim 48 \%$ are late Cretaceous, $\sim 17 \%$ are mid-Cretaceous, and $4 \%$ are Permian (Figures $8 \& 9$ ). Both samples from the Sierra Madre display a primary age peak in the latest Cretaceous ( 64-67 Ma) and a small mid-Cretaceous peak (108-115 Ma; Figures 8 \& 9).

\section{DISCUSSION}

\section{Provenance Comparisons to Published Data}


We used multi-dimensional scaling analysis (Vermeesch, 2013) to compare published detrital datasets to the new data of this study (Appendix 5). The multi-dimensional scaling plots measure dissimilarity, reflected as points on a dimensionless scale. Samples with similar detrital age distributions group together (Figure 10). The plot includes the 14 Eocene samples of this study, but excludes the Simmler and Sespe Formations as they are both late Eocene to early Oligocene and no published data exist for either unit (Figure 10). The results show that 11 of the 14 plotted samples group with published detrital zircon age data (Figure 10).

The Markley Formation samples (15VC01; 15VC02), Juncal Formation (17JUN-2), and the Greystone Formation (17GS-1) plot in different groups than the published ages compiled from ADD REFS (Figure 10). This may be attributed to sample locality differences. For example, the Markley Formation samples (15VC01; 15VC02) were gathered near Vacaville California, while the samples from an earlier study (Dumitru et al., 2013) were obtained near San Bruno Mountain to the west. Both Markley samples plot within the same group; whereas, the previously published dataset plots in an entirely different group.

The disparities between this study's data and published data may also be controlled by the difference in dataset size. For example, the Juncal Formation sample (17JUN-2) includes $\mathrm{n}=120$ grain ages, while previously published datasets were quite limited, with $\mathrm{n}<15$ grains (Jacobsen et al., 2011). This is a known limitation of multi-dimensional scaling as described by Vermeesch (2013).

\section{Provenance Refinement}

$\mathrm{U}-\mathrm{Pb}$ analyses from this study naturally fall into the seven source-age bins taken from previous studies (Figure 3; Table 2; Jacobsen et al., 2011; Sharman et al., 2015). Overall, the provenance data are dominated by a few major sources based on previously established provenance interpretations (Figure XX; Table 2). Mid-Cretaceous grains are sourced from the 
Sierra Nevada Arc and Jurassic and Permian-Triassic zircons reflect earlier segments of the Cordilleran arc found in eastern California, the Mojave Desert, and the Mogollon Highlands (Jacobsen et al., 2011). Both late Cretaceous zircons, sourced from Laramide-aged plutons, and Proterozoic zircons, sourced from anorogenic plutons of $\sim 1400$ Ma age and Yavapai-Mazatzal basement of $\sim 1700$ Ma age, are present in potential sources in the Mogollon Highlands and eastern Mojave Desert (Bilodeau, 1986; Dickinson and Gehrels, 2008; Jacobsen et al., 2011; Dickinson et al., 2012; Sharman et al., 2015; Table 2). Sources for Eocene grains include the Idaho Batholith/Challis Volcanic Center and $~ 70$ to 50 Ma granitic plutons in southwestern Arizona and Sonora, Mexico (Haxel et al., 1984; McDowell et al., 2001; Table 2). Sources could not be further refined from the (U-Th)/He analysis for the Vacaville and Santa Ynez Mountains areas due to reset ages. However, the U-Pb results from this study mimic those of previously published studies and therefore are utilized for the Vacaville and Santa Ynez Mountain sample groups (Jacobsen et al., 2011; Dumitru et al., 2013).

\section{Paleogene sources}

Paleogene grains (<65 Ma) are present throughout the dataset but no source rocks of this age are known in California (Jacobsen et al., 2011; Cassel et al., 2012b; Sharman et al., 2015). Previous workers have shown rivers that drained the Idaho Batholith (98-53 Ma) and Challis volcanic center (51-43 Ma) during the Eocene (e.g. Dumitru et al., 2013; Figure 11). Other established drainages out of the northern Sierra Nevada are interpreted to source volcanic rocks that overlap with Idaho Batholith detritus ages ( 44-29 Ma) in northern Nevada (Cassel et al., 2012b; Dumitru et al., 2013; Henry and John, 2013; Sharman et al., 2015; Figure 11). However, a source in northwestern Nevada seems unlikely based on the U-Pb ages of Eocene grains from this study (youngest grain ages between $\sim 49-43 \mathrm{Ma}$ ), which generally pre-date these volcanic 
rocks. Also, previous work (e.g. Cassel et al., 2012b) found that only late Eocene-Oligocene samples retained grains sourced from northwestern Nevada. Therefore, the Eocene U-Pb ages from samples in Vacaville (15VC01; 15VC02) and the Great Valley (17IONF-2; 17POR-1a) are likely to have been derived from the Idaho Batholith region between 53-43 Ma (Dumitru et al., 2013; Figure 11). The ZHe ages for these samples record middle Eocene ( $n=2 ; \sim 42-40 \mathrm{Ma}$ ) cooling, which generally coincides with cooling ages in the Idaho Batholith region associated with extensional exhumation (Fayon et al., 2017). Sediment from Idaho likely travelled along the paleo-Princeton River ( 53 Ma initiation), and once it reached the forearc, dispersed southward, longitudinally along the length of the Great Valley (Dumitru et al., 2013; Sharman et al., 2015; Figure 11). Eocene sediments in the Markley (17VC01; 15VC02) and Meganos (15MD01; 15MD02) formations are likely sourced from the same area based on sample localities and similarities in $\mathrm{U}-\mathrm{Pb}$ age spectra.

In contrast, the few Eocene grains found in samples farther south likely have a different source. Only two samples, the Juncal (17JUN-2; 17SES-1) and Sespe Formations, both from the Santa Ynez Mountain area, revealed Eocene grains (Appendix 4). Previous work has shown that samples from the Santa Ynez Mountains, record larger U-Pb populations of late Cretaceous (85$65 \mathrm{Ma}$ ), Jurassic (200-135 Ma), and >300 Ma (primarily Proterozoic) grains, and fewer midCretaceous arc-related grains (135-100 Ma; Sharman et al., 2015). This distribution of ages supports interpretations that suggest sediment sources in parts of Arizona and Sonora, Mexico, inboard of the Peninsular Ranges, where plutons as young as $\sim 50 \mathrm{Ma}$ are documented (Haxel et al., 1984; McDowell et al., 2001; Jacobsen et al., 2011; Sharman et al., 2015; Figure 11). However, grains from these samples are post-depositionally reset and thus, the (U-Th)/He dates provide no further refinement to the provenance (Appendix 5). 
The single youngest grain $(36.9 \pm 3.2 \mathrm{Ma})$ from the Sespe Formation $(17 \mathrm{SES}-1)$ in the Santa Ynez Mountains may have been sourced from Cenozoic ignimbrites associated with slab rollback, likely in Nevada or Arizona (Henry et al., 2012; Best et al., 2013). Slab rollback proceeded across Nevada occurred from northeast to southwest starting in the Eocene and is timed by the ages of volcanic rocks across the Great Basin (Humphreys, 1995; Henry et al., 2012; Best et al., 2013). By 45 Ma, volcanism would have reached northeastern Nevada, where eruptions lasted through the late Oligocene (Humphreys, 1995; Henry et al., 2012; Best et al., 2013). This supposition also correlates with Cassel and coauthers'(2009, 2012b) interpretation that only late Eocene-Oligocene sediments received zircons from Cenozoic volcanic rocks in Nevada.

\section{Sierra Nevada Arc}

The most prominent U-Pb age peak present in this study's dataset is owed to the most voluminous portion of Cretaceous Sierran arc (Cassel et al., 2012b; Jacobsen et al., 2011; Sharman et al., 2015). Although all samples contain mid-Cretaceous zircons associated with arc magmatism, samples from the Great Valley contain the largest proportion of these grains (Figure 4). The decrease in this arc-related age group southward supports previous work that suggests these regions (e.g. Sierra Madre) received very little sediment from the Sierra Nevada during this time (Sharman et al., 2015). This was likely reflective of their paleogeographic position adjacent to the Mojave in the Eocene (Figure 11). For the Santa Ynez Mountains samples, palinspastic reconstructions suggest that the source for mid-Cretaceous zircons $(\sim 100-85 \mathrm{Ma})$ is likely the Peninsular Ranges batholith, (Sharman et al., 2015; Figure 11). Cooling ages for this population of grains do not further refine the interpretations of the source, as $\mathrm{ZHe}$ ages for zircons sourced from the Sierra Nevada (135-85 Ma) indicate mid- ( 112-108 Ma) to late (87-69 Ma) Cretaceous 
cooling for the 135-100 Ma arc and late Cretaceous to Paleogene ( 81-51 Ma) cooling for the 100-85 Ma arc.

One Silurian grain was obtained from the Tesla Fm. (17TES-1) in the Great Valley group and records a mid-Cretaceous cooling age with a long lag-time ( $\sim 51 \mathrm{m.y.})$, but this is the only grain with this age combination. Few grains with similar U-Pb ages were found in the dataset, and therefore this source was likely not significant in the Eocene. It seems probable this grain may have been eroded from accreted Paleozoic terranes (e.g. Klamath and/or western Sierran Terranes; Figure 11; Sharman et al., 2015) in northern California and records mid-Cretaceous cooling associated with mid-Cretaceous batholith emplacement.

\section{Mojave Desert \& the Mogollon Highlands}

The Mogollon Highlands, Mojave Desert, and areas inboard of the Sierra Nevada arc are all host to multiple source rocks that may link to the age populations present in this dataset, including >300 Ma, Permian-Triassic, Jurassic, and late Cretaceous sources (Table 2; Figure 11). Jurassic and Permian-Triassic rocks represent earlier segments of the Cordilleran arc inboard of the Sierra Nevada, in the Mojave Desert (Table 2; Jacobsen et al., 2011). Permian-Triassic and Jurassic age populations are most prominent in samples from the Salinian Block and Sierra Madre; however, all sample groups contain grains of these ages (Figure 4).

The cooling ages for Jurassic and Permian-Triassic grains in all sample groups show some overlap with cooling ages on both late Cretaceous and early Cenozoic grains (Figures 12 \& 13). However, grains from Permian-Triassic source regions record late Cretaceous to Paleocene cooling for all sample groups whereas grains from Jurassic source regions record late Cretaceous to Eocene cooling (Figure 13). The similar cooling ages of Permian-Triassic grains present in all 
sample groups suggests all sample areas may have shared a common source (Figure 13). For Jurassic grains, a slight difference in Eocene cooling ages between the Great Valley/Salinian Block and Sierra Madre samples suggests Jurassic source regions and drainages were different from north to south (Figures $12 \& 13$ ). This distinction is compounded by different cooling ages on Proterozoic and late Cretaceous-sourced grains as well (Figure 13). Late Cretaceous zircon show late Cretaceous-Paleocene cooling in the Sierra Madre, versus the Paleocene-Eocene cooling ages from Salinian Block samples (Figures 12 \& 13). Similarly, Salinian Block samples record late Cretaceous-Paleocene cooling on Proterozoic grains; whereas, samples in the Sierra Madre record mid-Cretaceous and late Cretaceous cooling (Figure 13).

Although similarities in cooling ages for Permian-Triassic grains suggests all three sample groups share a source region in the Mojave; Proterozoic, Jurassic, and late Cretaceous grains may have been sourced from different regions for Sierra Madre samples (Jacobsen et al., 2011; Figures 11 \& 12). This inference seems reasonable given the Sierra Madres samples were likely adjacent to the southern Mojave region and in position to receive sediments from sources in the Mogollon Highlands and possibly the eastern Mojave Desert (Sharman et al., 2015; Figure 11). This dataset, with different cooling dates for late Cretaceous, Jurassic, and Proterozoic zircons, adds strength to published interpretations of source region distinction between the Salinian Block and Great Valley from the Sierra Madre (Sharman et al., 2015). Similar U-Pb age distribution patterns between the Sierra Madre and the Santa Ynez Mountains samples and the paleo-depositional locations suggests they likely shared source regions and related drainages (Figure 11).

\section{Source Region Lag-time and Cooling Date Trends}

The combined U-Pb and (U-Th)/He analysis above confirm both local (e.g. Sierra 
Nevada arc), inboard (e.g. Mojave and Mogollon Highlands), and extra-regional (e.g. Idaho Batholith) sources for Eocene forearc and trench-slope sediments. The cooling ages, in conjunction with lag-time analysis, allows inferences to be made on timing and rates of exhumation in the potential source regions. For lag-time analysis, we first needed to identify syndepositional volcanic (first-generation) zircons that should be excluded from depositional lagtime analysis. It is necessary to identify such volcanic zircon, as they can convolute depositional lag-time analysis (Ruiz et al., 2004; Saylor et al., 2012). Syndepositional volcanic zircon identification was done by calculating the difference between the U-Pb and (U-Th)/He ages and comparing that with the standard (U-Th)/He uncertainty (Saylor et al., 2012). If the difference is smaller than the uncertainty and overlaps with the depositional age, it is considered syndepositional volcanic (Saylor et al., 2012). The Butano Sandstone (17BUT-1) produced one grain that falls within this criterion (U-Pb age: $108.1 \pm 3.5$; (U-Th)/He age: $108.2 \pm 8.7 \mathrm{Ma}$; Figure 6). However, this grain is older than the depositional age (i.e. not syndepositional) and is therefore likely recycled.

The majority of samples analyzed $(10 / 16 ; n=86)$ have positive lag-times (Figure 13), ranging from $\sim$-177 m.y., and are discussed in detail below. However, six samples produce negative lag-times that are likely a consequence of post-depositional resetting (Appendix 7; Figure 13). Most of these samples are from the Santa Ynez Mountains area and the Vacaville area and were in close proximity to known faults. Lag-times for these samples are therefore not conducive to the overall discussion.

\section{Mid-Cretaceous arc rocks}

Mid-Cretaceous arc-sourced grains (U-Pb age: 135-85 Ma) show variable lag-time patterns for each sample group (Figure 13). Both the Salinian Block and Great Valley groups 
show similar lag-time trends for this source region and record late Cretaceous ( 87-69 Ma) cooling ages on 135-100 Ma grains and lag-times of 14-35 m.y. (Appendix 7). Two midCretaceous $\sim 110$ Ma grains with much longer lag-times ( 60 m.y.) are present in the Salinian Block and Sierra Madre and we assess them as recycled (Appendix 7; Figure 12).

The eastern arc segment (100-85 Ma) cooled in two stages for samples in the Great Valley and Salinian Block: in the late Cretaceous and Paleocene-Eocene (Figure 13). Lag-times for the late Cretaceous cooling are generally extended ( 20-30 m.y), whereas lag-times for the Paleocene-Eocene cooling become significantly shorter ( 15-0 m.y.; Appendix 7; Figures 12 \& 13). A single grain recovered from the Meganos Fm. in the Great Valley has a (U-Th)/He date of $50.6 \pm 4.05 \mathrm{Ma}$ and $\sim 0$ m.y. lag-time, the only grain with such a short lag-time, likely sourced from the Sierra Nevada. The Sierra Madre samples, which were deposited the farther south, record long lag-times ( 30-40 m.y.; Appendix 7; Figure 13) and as previously described, likely were not receiving significant amounts of sediment from the Sierra Nevada arc in the Eocene (Figure 11).

\section{Jurassic and Permian-Triassic}

Both Jurassic and Permian-Triassic sediment sources occupy similar areas, either inboard of the Sierra Nevada, the Mojave Desert, or in the Mogollon Highlands (Table 2; Figure 11). Jurassic rocks can also be found in the northern Sierra Nevada and Klamath Mountains. The lagtimes and cooling ages for these source regions, represented in each sample group, are similar, but spatial trends do exist. Lag-times for all sample groups range from 40-0 m.y., but most are shorter than 25 m.y. (Figure 13). Two grains, one from the Sierra Madre and one grain from the Great Valley record mid-Cretaceous cooling ages and long (>50 m.y.) lag-times. Three grains, one from each sample group, record $\sim 0$ m.y. lag-times on grains with cooling dates from 58-49 
Ma (Appendix 7; Figure 13) which is the highest abundance of rapid lag-times of all source regions.

Permian-Triassic grains also show two populations of lag-times for each sample group, with lag-times of 30-40 m.y. for grains with 90-61 Ma cooling dates or 20-10 m.y. on grains with 85-58 Ma cooling dates. No $\sim 0$ m.y. lag-times are observed for Permian-Triassic rocks (Appendix 7; Figure 13). Permian-Triassic sources appear to have finished cooling by the Paleocene, but rocks of this age are sparse in California, which may have produced a bias in cooling ages rather than representing differences in cooling patterns.

\section{Late Cretaceous and Proterozoic}

Similar to Jurassic and Permian-Triassic sources, the Proterozoic and Late Cretaceous source regions occupy similar areas, although Proterozoic sources reach farther inland, possibly to the Mogollon Highlands (Figure 11). Late Cretaceous sediment source regions revealed generally rapid lag-times $\sim 11$ to 0 m.y. for grains that cooled predominantly in the Paleocene to Eocene (Appendix 7; Figure 13). One longer lag-time of 30 m.y. was produced from the late Eocene-Oligocene Simmler Formation (Sierra Madre) with a cooling age in the late Cretaceous but is likely a function of a younger depositional age (Table 1; Appendix 7).

Only the Sierra Madre and Salinian Block samples produced enough Proterozoic grains for lag-time and cooling age analysis. The single double-dated Proterozoic grain from the Ione Formation (Great Valley) is a Grenville-age grain, which is likely recycled from the Cordilleran Miogeocline, and therefore removed from further assessment. Proterozoic lag-times for the Salinian Block samples are variable, with some long ( 30-35 m.y.) and moderate ( 16-18 m.y.) lag-times for grains that cooled in either the late Cretaceous or Paleocene and likely came from 
the eastern Mojave Desert (Appendix 7; Figure 13). Grains with Paleocene (U-Th)/He age that have longer lag-times ( 16-18 m.y.) may reflect longer distance transport from the eastern Mojave (Figure 13). The Sierra Madre samples only record very long lag-times that group in two populations: (1) 35-50 m.y. for grains with late Cretaceous cooling dates and 65-80 m.y. for grains with mid-Cretaceous cooling dates (Appendix 7; Figure 13). Therefore, it appears that the Mogollon Highlands, where Proterozoic grains from the Sierra Madre samples are inferred to have been sourced from, experienced exhumation in the late Cretaceous; whereas, in the eastern Mojave, Proterozoic sources were exhumed in the Paleocene ( 63 Ma) but have longer lag-times due to larger transport distances between sources and sinks (Figures $11 \& 13$ ).

\section{Summary of Lag-time and Cooling Date Trends}

Lag-times and associated (U-Th)/He dates suggest two periods of cooling, one in the late Cretaceous, characterized by prolonged lag-times, and one in the latest Cretaceous to Eocene, with generally rapid lag-times ( $<10$ m.y.) (Figure 13$)$. The trend of the decreasing lag-times and related cooling dates from the various source regions suggests that rapid exhumation and erosion in the early Cenozoic was focused in the Mojave Desert, possibly the westernmost Mogollon Highlands, and in the eastern Sierra Nevada arc (Figure 13). The largest number of young (UTh)/He dates were sourced from Jurassic-age rocks and suggest exhumation was widespread along the western continental margin in the Eocene (Figure 13). The data also suggest that sources farther inboard, in the eastern Mojave or the eastern Mogollon Highlands, likely saw exhumation cease by the late Cretaceous or Paleocene. In the eastern Mojave, longer lag-times for grains with Paleocene (U-Th)/He cooling date may imply that transport distance was a factor. Long lag-times recovered on grains sourced from Proterozoic rocks, as seen in the Sierra Madre samples, suggest Eocene rapid exhumation did not reach the Mogollon Highlands in Arizona 
(Figure 13).

\section{Drivers of Exhumation}

Detrital zircon (U-Th)/He dates from this study suggest two-stages of cooling and/or exhumation for sediment sources inboard of the Sierra Nevada. This observation is consistent with trends recognized from low-temperature thermochronology data from the Sierra Nevada, western Great Basin, and Mojave Desert that show widespread bimodal cooling in the late Cretaceous and Eocene (e.g., e.g. Surpless et al., 2002; Stockli et al., 2002, 2003; Lee et al., 2009; Mahan et al., 2009; Ferrill et al., 2012; Gorynski et al., 2013; Walker et al., 2014; Bidgoli et al., 2015). A number of possible drivers for cooling and/or exhumation in the region have been proposed (Hodges and Walker, 1990; Applegate et al., 1992; House et al., 1997; Wood and Saleeby, 1997; Stockli et al., 2002, 2003, Yin 2002, DeCelles, 2004, Clark et al., 2005; Glazner et al., 2005; Bartley et al., 2007; Wells and Hoisch, 2008; Chapman et al., 2012; see Figures 14 $\& 15)$ and here, we summarize those and then apply them to the trends observed in our dataset.

\section{Sierra Nevada Arc}

Our data suggest that sediments derived from the Sierra Nevada arc cooled from the midto late Cretaceous, in the western arc, and from the latest Cretaceous through Eocene, in the eastern arc, a pattern that generally correlates with documented arc migration trends (Chen and Moore, 1982; Figures $11 \&$ 13). By the Paleogene, lag-times shorter than 10 m.y. suggest that rapid exhumation was focused along the eastern arc in the Eocene (Figure 13). Sierra Nevada cooling patterns have previously been proposed to be a result of a crustal refrigeration associated with Laramide flat-slab subduction at around $\sim 75$ Ma (Dumitru et al., 1991; Figures $14 \& 15$ ). Magmatic arc cooling and exhumation from $~ 80-60$ Ma has also been suggested (Stockli et al., 2003; Figure 15). In addition, rapid erosional unroofing, driven by batholith exhumation and 
related topographic relief, of the eastern Sierra Nevada magmatic arc, beginning at $~ 75-70 \mathrm{Ma}$ in the central and southern portions of the range and from $~ 90-60$ Ma in the northern Sierra Nevada, has been described (House et al., 1997; Cecil et al., 2006; Figure 14). Extensional unroofing of the southern Sierra Nevada has also been suggested, driven largely by the effects of shallow Farallon plate subduction and subduction of the Shatksy plateau in the late Cretaceous, but timing of this event is poorly constrained (Saleeby et al., 2007; Chapman et al., 2012; Blythe and Longinotti, 2013; Nadin et al., 2016; Sousa et al., 2017; Figure 14). Similarly, a suite of shear zones, documented in the central Sierra Nevada, record mid-Cretaceous cooling ages that may be reflective of arc contraction driven by plate kinematic shifts (Nadin et al., 2016; Figure 14). The only episode of tectonic exhumation within the arc during the Eocene was documented in the southern Sierra Nevada and the Sierran foothills, where middle Eocene fault activity ( 45 $40 \mathrm{Ma}$ ) near the Kern and San Joaquin rivers along the Western Sierra fault system caused $\sim 1$ km of exhumation (Sousa et al., 2016; Figure 14). Many of these events show high temporal overlap, and thus must be deciphered based on spatial relationships and the tempo of processes.

The progressive younging of cooling ages and decreasing lag-times from the western to eastern arc may point to cooling of the magmatic arc following eastern migration and cessation, although Cretaceous cooling ages could also reflect southern Sierra Nevada unroofing due to shallowing slab geometry and subduction of the Shatksy Plateau (Chen and Moore, 1982; Stockli et al., 2003; Saleeby et al., 2007; Chapman et al., 2012; Blythe and Longinotti, 2013; Nadin et al., 2016; Sousa et al., 2017; Figures $14 \&$ 15). The cooling ages and rapid lag-times from the eastern arc pre-date faulting documented along the Western Sierra fault system ( $45-40 \mathrm{Ma}$; Sousa et al., 2016/2017), are generally younger than the timing of magmatic arc cooling ( $\sim 80-60$ Ma; Stockli et al. 2002), and therefore could reflect a period of rapid erosional unroofing from 
the latest Cretaceous through early Cenozoic (House et al., 1997; Cecil et al., 2006; Nadin et al., 2016; Figure 14).

\section{Inboard Source}

Although eastern arc-sourced grains record a two-stage cooling, a broader bimodal late Cretaceous and early Cenozoic cooling pattern is also apparent for Jurassic, Permian-Triassic, Proterozoic, and late Cretaceous grains. For these potential sediment sources inboard of the Sierra Nevada, in the western Great Basin, Mojave Desert, and Mogollon Highlands, other explanations are needed for the pattern of cooling ages revealed in this study (Figure 13). Previously published studies have attributed late Cretaceous and/or early Cenozoic cooling to Laramide deformation. For example, episodes of exhumation at $\sim 66$ and $54 \mathrm{Ma}$ in the Inyo Mountains documented by Lee et al. (2009) are coincident with late Cretaceous to Paleogene dextral shear in Owen's Valley, California (Glazner, 2005; Bartley et al., 2007; Figure 14). Likewise, thermochronologic studies from from the Mojave and western Great Basin have revealed two stages of rapid cooling at $\sim 65$ and $\sim 55-50$ Ma in multiple mountain ranges (Bidgoli, 2014; Figure 14). In the Funeral Mountains, extensional unroofing occurred in the late Cretaceous ( 72-70 Ma; Applegate, 1992) and in the Black Mountains, Paleocene to early Eocene ( 61-55 Ma) thrusting has also been documented (Miller and Friedman, 1999; Figure 14). In southeastern California, similar periods of faulting and rapid exhumation have been documented along the Chocolate Mountains fault ( 60-44 Ma) and as unroofing in the Orocopia Mountains (initiation at 52-50 Ma) (Jacobsen et al., 2002; Jacobsen et al., 2007; Figure 14). In the eastern Mojave, evidence supporting a 75-67 Ma extensional event is documented in the Granite Mountains, Old Woman-Piute Mountains, New York Mountains, and the Iron Mountains that are considered the result of mantle delamination associated with Laramide shallow-slab 
subduction (Wells and Hoisch, 2008; Figure 14). Farther east, accelerated deformation has been documented in the Green River Basin during the late Paleocene and Eocene, likely driven by initiation of slab rollback at that time (Fan and Carrapa, 2014).

Lag-time and cooling age trends for inboard sediment sources regions are broadly similar to those observed in the Sierra Nevada from this study. Generally, longer lag-times are associated with grains with that cooled in the Cretaceous and rapid lag-times with grains that cooled in the early Cenozoic (Figure 13). A few grains with mid-Cretaceous cooling dates are associated with prolonged lag-times (> 60 m.y.) for these source regions (with the exception of late Cretaceous sources; Figure 13). These grains could be recycled although they primarily are found in Sierra Madre samples, suggesting it is characteristic of this sample group. MidCretaceous cooling ages were recorded on Jurassic and Proterozoic grains, likely sourced from the Mogollon Highlands. Mid-Cretaceous cooling broadly coincides with the timing of uplift and tilting of the Mogollon rift shoulder, and therefore may be related (Bilodeau, 1986).

Across Proterozoic, Permian-Triassic, and Jurassic source regions, the first major stage of cooling occurred $\sim 82$ to $77 \mathrm{Ma}$ (Figure 13). This timing overlaps with the timing of documented changes in plate convergence rates, the trajectory of the subducting Farallon slab, and the subduction of the Shatksy Plateau ( $\sim 85 \mathrm{Ma})$, as well as on the onset of flat-slab subduction $(\sim 75$ Ma) during the Laramide orogeny (Engebretson et al., 1985; Liu et al., 2010; Nadin et al., 2016; Seton et al., 2012). Therefore, we infer these events and this study's cooling ages to be related.

The second episode of cooling apparent in our dataset is latest Cretaceous to Paleogene, which is pervasive through the majority of source regions (Figure 13). Based on the spatial extent of this cooling across multiple source regions, we suggest a widespread rapid exhumation event was occurring inboard of the Sierra Nevada and south through the Mojave Desert, as well 
as possibly into parts of the Mogollon Highlands by 65 Ma (Figure 13). This episode of cooling appears to have progressed from west to east, where Jurassic and Permian-Triassic source regions, which occupy similar areas in the Mojave and western Great Basin, record late Cretaceous through Paleogene cooling (Figure 13). Proterozoic and late Cretaceous source regions which are present farther inland appear to cool later in the Paleocene (Figure 13). Thus, cooling appears to have initiated in Jurassic/Permian-Triassic source regions in the latest Cretaceous and progressed into the eastern Mojave and potentially the Mogollon Highlands by the Paleocene (Figure 13).

The cooling age data from this study inform us about the viability of different causes of cooling. Generally, cooling in the latest Cretaceous-early Cenozoic have been attributed to crustal refrigeration driven by flat-slab subduction (Dumitru et al., 1991), magmatic arc cooling (Stockli et al., 2003), or erosional unroofing (House et al., 1997). Crustal refrigeration (Dumitru, 1991) in the region would produce widespread cooling in the area of the shallow slab but cooling would be slower and monotonic, whereas data in this study suggest cooling occurred in pulses over this time period (Figure 14). Likewise, the timing of magmatic arc cooling ( 80-60 Ma; Stockli et al., 2003) broadly overlaps with cooling ages in the early Cenozoic, but the patterns of inboard cooling do not appear related. Rapid erosional unroofing has previously only been described for the arc and was likely driven by high-relief topography following crustal thickening and/or magmatic addition (House et al., 1997; Cecil et al., 2006). Alternatively, other studies from the Mojave and western Great Basin suggest Laramide-related deformation as an explanation for late Cretaceous and/or Paleogene cooling, with many showing a suspicious 65 Ma cooling episode (e.g. Surpless et al., 2002; Stockli et al., 2002, 2003; Wells and Hoisch, 2008; Lee et al., 2009; Mahan et al., 2009; Ferrill et al., 2012; Gorynski et al., 2013; Walker et 
al., 2014; Bidgoli, 2014; Bidgoli et al., 2015). We suspect the second episode of cooling in this study, which correlates with documented cooling associated with Laramide deformation in the Mojave and western Great Basin, are therefore related.

Although Laramide deformation is likely responsible for the primary cooling peaks in the latest Cretaceous-early Cenozoic in this study, this does not explain rapid, widespread cooling by the Eocene as reflected by the short ( $\sim 0$ m.y.) lag-times calculated in this study across multiple source regions (Figure 13). It has previously been proposed that rapid exhumation in the early Cenozoic as a function of climate may play a part in Sierra Nevada cooling patterns (Cecil et al., 2006), but the roles of climate, tectonics, and erosion are difficult to differentiate (Whipple, 2009). However, the locus of Laramide deformation in the early Cenozoic was likely in the continental interior (Liu et al., 2010) and the timing of effects from slab rollback, which initiated in the late Paleocene-early Eocene, likely did not reach sediment source regions until the Oligocene (Humphreys, 1995). Alternatively, the early Cenozoic is characterized as a transition from a hot, arid to hot, humid environment, which may have been conducive to enhanced erosion in forearc source regions. Previous work has identified global thermal and climatic episodes such as the Late Paleocene ( 55 Ma) Thermal Maximum (LPTM; Zachos et al., 2001) and Early ( 53$50 \mathrm{Ma}$ ) and Middle ( 42 Ma) Eocene Climatic Optimums (Zachos et al., 2001; 2008) that coincide with timing of Cenozoic cooling ages and rapid lag-times revealed in this study (Figures $14 \& 15)$. Prior to the LPTM, the climate was arid and seasonally wet as documented in paleosols in southern California which may have destabilized and eroded soil regoliths exposing source region bedrock (Torres and Gaines, 2013). By the early Eocene, warm, wet conditions prevailed and culminated by the EECO which may have quickly eroded, transported, and deposited sediments as reflected by the rapid lag-times. 
Climate-enhanced erosion in the study area is also supported by other lines of evidence such as provenance shifts previously documented in both detrital zircon and conglomerate clast provenance studies, indicating a shift from local sources to extra-regional sources during the latest Cretaceous/early Cenozoic that implies more integrated drainages and head-ward erosion inboard of the Sierra Nevada Arc (Nilsen and Clarke, 1975; Cox, 1982; Kies and Abbott, 1983; Howard, 2000; Lechler and Niemi, 2011; Jacobsen et al., 2011; Cassel et al., 2012b; Sharman et al., 2015). Similarly, documented widespread lateritic paleosol development (Allen, 1929; Batemen and Wahrhaftig, 1966; Peterson and Abbott, 1979) and increases in kaolinite development in sedimentary successions in Eocene paleovalleys in the Sierra Nevada also suggest intense chemical and physical weathering and of bedrock erosion were occurring at high altitudes (Robert and Chamley, 1991; Gibson et al., 1993; Bolle et al., 1998; Knox 1998; Schmitz et al., 2001; Thiry and Dupuis, 2000). Further evidence for widespread enhanced erosion in the early Cenozoic comes from studies in Green River Basin and Gulf of Mexico where sediments sourced from the Laramide belt also document enhanced chemical and physical erosion which coincides with the timing of the LPTM and EECO (Smith et al., 2008; Hessler et al., 2017).

Based on the compiled information, it seems reasonable that a widespread erosional event was likely at work by the Eocene and was not only constrained to the eastern Sierra Nevada, but also inboard sources in the Mojave, eastern California, and possibly parts of the Mogollon Highlands (Figure 14). Therefore, to explain early Cenozoic cooling ages and rapid lag-times by the Eocene observed in this study we suggest: 1) early Cenozoic cooling and exhumation was connected between the arc and inboard regions and related to Laramide deformation and 2) that high topographic relief developed during the prolonged Mesozoic to early Cenozoic subduction 
followed by documented global climate shifts from an arid to warm, wet climate induced widespread enhanced erosion and exhumation by the Eocene.

\section{CONCLUSIONS}

This study addresses provenance and cooling patterns via $\mathrm{U}-\mathrm{Pb} /(\mathrm{U}-\mathrm{Th}) / \mathrm{He}$ double-dating of Eocene forearc sediments that were likely in part sourced from the western Nevadaplano. U$\mathrm{Pb}$ results support previous provenance interpretations suggesting sediments were sourced from Sierra Nevada and Peninsular Ranges arcs, the Mojave Desert, Mogollon Highlands, and the Idaho Batholith. (U-Th)/He ages reveal that samples from the Salinian Block, Great Valley, and Sierra Madre all share some source regions in the Mojave. However, we found differences in cooling ages for similarly aged sources that suggest the Sierra Madre were also tapping into the eastern Mojave and Mogollon Highlands.

The majority of samples in the dataset record late Cretaceous and/or an early Cenozoic cooling, which correlates with the timing of a previously recognized two-stage cooling history. Cooling ages obtained in this study support late Cretaceous cooling driven by large-scale tectonic shifts such as subduction of the Shatsky Plateau and changes in plate convergence rates and/or trajectories. Widespread early Cenozoic exhumation in the Sierra Nevada, Mojave, western Great Basin, and Mogollon Highlands may have resulted from a combination of Laramide deformation and enhanced erosion, driven by well-documented changes early Cenozoic climate. 


\section{REFERENCES}

Allen, V.T., 1929, The Ione Formation of California: Berkeley, University of California Department of Geological Sciences Bulletin, v. 18, p. 347-448.

Almgren, A.A., and Filewicz, M.V., 1984, Benthic foraminiferal and calcareous nannofossil biostratigraphy of the Markley Canyon fill, in Almgren, A.A., and Hacker, P.D., eds., Paleogene submarine canyons of the Sacramento Valley, California: Los Angeles, Pacific Section, American Association of Petroleum Geologists, p. 115-124.

Anderson, K.S., 1998, Facies architecture of two Paleogene structurally-controlled turbidite systems, central California [Ph.D. thesis]: Stanford, Stanford University, 391 p.

Andersen, T., 2005, Detrital zircons as tracers of sedimentary provenance: limiting conditions from statistics and numerical simulation: Chemical Geology, v. 216, p. 249-270.

Applegate, J.D.R., Walker, J.D., and Hodges, K.V., 1992, Late Cretaceous extensional unroofing in the Funeral Mountains metamorphic core complex, California: Geology, v. 20, p. 519522.

Ballance, P.F., Howell, D.G., and Ort, K., 1983, Late Cenozoic wrench tectonics along the Nacimiento, South Cuyama, and La Panza faults, California, indicated by depositional history of the Simmler Formation, in Anderson, D.W., and Rymer, D.J., eds., and Sedimentation along Faults of the San Andreas System, Los Angeles, California, Society of Economic Paleontologists and Mineralogists, Pacific Section, p. 1-9.

Barth, A. P., Walker, J. D., Wooden, J. L., Riggs, N. R., and Schweickert, R. A., 2011, Birth of the Sierra Nevada magmatic arc: Early Mesozoic plutonism and volcanism in the east-central Sierra Nevada of California: Geosphere, v. 7, 877-897.

Bartley, J.M., Glazner, A.F., Coleman, D.S. Kylander-Clark, A., Mapes, R., and Friedrich, A.M., 2007, Large Laramide dextral offset across Owens Valley, California, and its possible 
relation to tectonic unroofing of the southern Sierra Nevada, in Till, A.B., Roeske, S.M., Foster, D.A., and Sample, J.C., eds., Exhumation Processes along Major Continental StrikeSlip Fault Systems: Geological Society of American Special Paper, v. 434, p.129-148.

Bartow, J.A., Lettis, W.R., Sonneman, H.S., and Switzer, J.R., Jr., 1985, Geologic map of the east flank of the Diablo Range from Hospital Creek to Poverty Flat, San Joaquin, Stanislaus, and Merced counties, California: U.S. Geological Survey Miscellaneous Investigation Series, Map I-1656.

Bartow, J. A., 1991, The Cenozoic evolution of the San Joaquin Valley, California: U.S. Geological Survey Professional Paper, v. 1501, 40 p.

Bateman, P.C. and Wahrhaftig, Clyde, 1966, Geology of the Sierra Nevada, in Bailey, E.H., ed., Geology of northern California: California Division of Mines and Geology Bulletin 190, p.107-172.

Beaulieu, J.D., 1970, Cenozoic stratigraphy of the Santa Cruz Mountains, California and inferred displacement along the San Andreas fault [Ph.D. thesis]: Stanford, Stanford University, 202 p.

Bernet, M., Zattin, M., Garver, J.I., Brandon, M.T., and Vance, J.A., 2001, Steady-state exhumation of the European Alps: Geology, v. 29, p. 35-38.

Best, M.G., Barr, D.L., Christiansen, E.H., Gromme, S., Deino, A.L., and Tingey, D.G., 2009, The Great Basin Altiplano during the middle Cenozoic ignimbrite flareup: Insights from volcanic rocks: International Geology Review, v. 51, p. 589-633.

Best, M.G., Christiansen, E.H., and Gromme, S., 2013, Introduction: The 36-18 Ma southern Great Basin, USA, ignimbrite province and flareup: Swarms of subduction-related supervolcanoes: Geosphere, v. 9, p. 260-274. 
Best, M.G., Christiansen, E.H., de Silva, S., and Lipman, P.W., 2016, Slab-rollback ignimbrite flareups in the southern Great Basin and other Cenozoic American arcs: A distinct style of arc volcanism. Geosphere, v. 12, 1097-1135.

Bidgoli, T.S., Amir, E., Walker, J.D., Stockli., D.F., Andrew, J.E., and Caskey, S.J., 2015, Lowtemperature thermochronology of the Black and Panamint mountains, Death Valley, California: Implications for geodynamic controls on Cenozoic intraplate strain: Lithosphere, v. 7, p. $473-480$.

Bilodeau, W.L., 1986, The Mesozoic Mogollon Highlands, Arizona: An Early Cretaceous rift shoulder: The Journal of Geology, v. 94, p. 724-735.

Blake, T.F., 1982, Depositional environments of the Simmler Formation in southern Cuyama Valley, Santa Barbara and Ventura Counties, California, in Ingersoll, R. V. and Woodburne, M.O., eds., Cenozoic Nonmarine Deposits of California and Arizona: Los Angeles, Pacific Section, Society of Economic Paleontologists and Mineralogists, p. 35-50.

Blythe, A.E., and Longinotti, N., 2013, Exhumation of the southern Sierra Nevada-eastern Tehachapi Mountains constrained by low-temperature thermochronology: Implications for the initiation of the Garlock fault: Lithosphere, v. 5, p. 321-327.

Bolle, M.P., Adatte, T., Keller, G., Von Salis, K., and Hunziker, J., 1998, Biostratigraphy, mineralogy, and geochemistry of the Trabakua Pass and Ermua sections in Spain: PaleoceneEocene transition: Eclogae Geologicae Helvetiae, v. 91, p. 1-25.

Bottjer, D.J., and Link, M.H., 1984, A synthesis of Late Cretaceous southern California and northern Baja California paleogeography, in Crouch, J.K., and Bachman, S.B., eds., Tectonics and Sedimentation Along the California Margin: Los Angeles, Pacific Section, SEPM (Society for Sedimentary Geology), Book 38, p. 171-188. 
Brabb, E.E., 1997, Geological map of Santa Cruz County, California: a digital database, U.S. Geological Survey, scale 1:62,500.

Campbell, I.H., Reiners, P.W., Allen, C.M., Nicolescu, S., and Upadhyay, R., 2005, He-Pb double dating of detrital zircons from the Ganges and Indus Rivers: Implication for quantifying sediment recycling and provenance studies: Earth and Planetary Science Letters, v. 237, p. 402-432.

Cassel, E.J., Calvert, A., and Graham, S.A., 2009, Age, geochemical composition, and distribution of Oligocene ignimbrites in the northern Sierra Nevada, California: Implications for landscape morphology, elevation, and drainage divide geography of the Nevadaplano: International Geology Review, v. 51, p. 723-742.

Cassel, E.J., and Graham, S.A., 2011, Paleovalley morphology and fluvial system evolution of Eocene-Oligocene sediments (“auriferous gravels"), northern Sierra Nevada, California: Implications for climate, tectonics, and topography: Geological Society of America Bulletin, v. 123, p. 1699-1719.

Cassel, E.J., Graham, S.A., Chamberlain, C.P., and Henry, C.D., 2012a, Early Cenozoic topography, morphology, and tectonics of the northern Sierra Nevada and western Basin and Range: Geosphere, v. 8, p. 229-249.

Cassel, E.J., Grove, M., and Graham, S.A., 2012b, Eocene drainage evolution and erosion of the Sierra Nevada batholith across northern California and Nevada: American Journal of Science, v. 312, p. 117-144.

Cassel, E.J., Breeker, D.O., Henry, C.D., Larson, T.E., and Stockli, D.F., 2014, Profile of a paleo-orogen: High topography across the present-day Basin and Range from 40 to 23 Ma: Geology, v. 42, p. 1007-1010. 
Cecil, M.R., Ducea, M.N., Reiners, P.W., and Chase, C.G., 2006, Cenozoic exhumation of the northern Sierra Nevada, California, from (U-Th)/He thermochronology: Geological Society of America Bulletin, v. 118, p. 1481-1488, doi: 10.1130/B25876.1.

Chapman, A.D., Saleeby, J.B., Wood, D.J., Piasecki, A., Kidder, S., Ducea, M.N., and Farley, K.A., 2012, Late Cretaceous gravitational collapse of the southern Sierra Nevada batholith, California: Geosphere, v. 8, p. 314-341.

Chapman, J.B., Ducea, M.N., DeCelles, P.G., and Profeta, L., 2015, Tracking changes in crustal thickness during orogenic evolution with $\mathrm{Sr} / \mathrm{Y}$ : An example from the North American Cordillera: Geology, v. 43, p. 919-922.

Chen, J. H., and Moore, J.G., 1982, Uranium-lead isotopic ages from the Sierra Nevada batholith, California: Journal of Geophysical Research: Solid Earth, v. 87, p. 4761-4784.

Cherven, V.B., 1983, Mesozoic through Paleogene evolution of the Sacramento basin, California, in Cherven, V.B., and Graham, S.A., Geology and sedimentology of the southwestern Sacramento basin and East Bay hills: Pacific Section, SEPM (Society for Sedimentary Geology), Field Trip Guidebook, p. 21-32.

Clark, M.K., Maheo, G., Saleeby, J., and Farley, K.A., 2005, The non-equilibrium landscape of the southern Sierra Nevada, California: GSA Today, v. 15, p. 4-10.

Clark, B.L., 1921, The stratigraphic and faunal relationships of the Meganos Group, middle Eocene of California: The Journal of Geology, v. 29, p. 125-165.

Colgan, J.P., Dumitru, T.A., Reiners, P.W., Wooden, J.L., and Miller, E.L., 2006, Cenozoic tectonic evolution of the Basin and Range Province in northwestern Nevada: American Journal of Science, v. 306, p. 616-654.

Colgan, J.P., and Henry, C.D., 2009, Rapid middle Miocene collapse of the Mesozoic orogenic plateau in north-central Nevada: International Geology Review, v. 51, p. 920-961. 
Coney, P.J., and Reynolds, S.J., 1977, Cordilleran Benioff zones: Nature, v. 270, p. 403-405.

Coney, P.J., and Harms, T.J., 1984, Cordilleran metamorphic core complexes: Cenozoic extensional relics of Mesozoic compression: Geology, v. 12, p. 550-554.

Copeland, P., Currie, C.A., Lawton, T.F., and Murphy, M.A., 2017, Location, location location: the variable lifespan of the Laramide orogeny: Geology, v. 45, p. 223-226.

Cox, B.F., 1982, Stratigraphy, sedimentology, and structure of the Goler Formation (Paleocene), El Paso Mountains, California: Implications for Paleogene tectonism on the Garlock Fault Zone [Ph.D. thesis]: Riverside, University of California, 248 p.

Creely, S., and Force, E.R., 2007, Type region of the Ione Formation (Eocene), central California: Stratigraphy, paleogeography, and relation to auriferous gravels: U.S. Geological Survey Open-File Report, 2006-1378, 65 p.

Critelli, S., and Nilsen, T.H., 1996, Petrology and diagenesis of the Eocene Butano Sandstone, La Honda basin, California: Journal of Geology, v. 104, p. 295-315, doi:10.1086/629826.

DeCelles, P.G., 2004, Late Jurassic to Eocene evolution of the Cordilleran thrust belt and foreland basin system, western U.S.A.: American Journal of Science, v. 304, p. 105-168, doi:10.2475/ajs.304.2.105.

DeGraaff-Surpless, K., Graham, S.A., Wooden, J. L., and McWilliams, M. O., 2002, Detrital zircon provenance analysis of the Great Valley Group, California: Evolution of an arcforearc system: Geological Society of America Bulletin, v. 114, p. 1564-1580.

Dibblee, T.W., 1986, Geologic map of the Santa Barbara Quadrangle, Santa Barbara County, California: Dibblee Geological Foundation Map DF-06, scale 1:24,000.

Dibblee, T. W., 2006a, Geologic map of the Sawtooth Ridge and Emigrant Hill quadrangles, Kern County, California: Dibblee Geological Foundation Map DF-266, scale 1:24,000. 
Dibblee, T. W., 2006b, Geologic map of the Miranda Pine Mountain quadrangle, San Luis Obispo, California. Dibblee Geological Foundation Map DF-265, scale 1:24,000.

Dibblee, T.W., 1982, Preliminary geologic map of the Patterson quadrangle, Stanislaus County, California: U.S. Geological Survey, Open-File Report OF-82-394, scale 1:24,000.

Dickinson, W.R., and Snyder, W.S., 1978, Plate tectonics of the Laramide orogeny: Geological Society of America Memoir 151, p. 355-366.

Dickinson, W.R., and Seely, D.R., 1979, Structure and stratigraphy of forearc regions: American Association of Petroleum Geologists Bulletin, v. 63, p. 2-31.

Dickinson, W.R., 1995, Paleogene depositional systems of the western Transverse Ranges and adjacent southernmost Coast Ranges, California, in Fritsche, A.E., ed., Cenozoic Paleogeography of the Western United States Part II: Los Angeles, Pacific Section, SEPM (Society for Sedimentary Geology), Book 75, p. 58-83.

Dickinson, W.R., 2006, Geotectonic evolution of the Great Basin: Geosphere, v. 2, p. 353-368.

Dickinson, W.R., 2008, Accretionary Mesozoic-Cenozoic expansion of the Cordilleran continental margin in California and adjacent Oregon: Geosphere, v. 4, p. 329-353.

Dickinson, W.R., and Gehrels, G.E., 2008, Sediment delivery to the Cordilleran foreland basin: Insights from $\mathrm{U}-\mathrm{Pb}$ ages of detrital zircons in Upper Jurassic and Cretaceous strata of the Colorado Plateau: American Journal of Science, v. 308, p. 1041-1082.

Dickinson, W.R., and Gehrels, G.E., 2009. Use of U-Pb ages of detrital zircons to infer maximum depositional ages of strata: a test against a Colorado Plateau Mesozoic database: Earth and Planetary Science Letters, v. 288, p. 115-125.

Dickinson, W.R., and Gehrels, G.E., 2010, Insights into North American Paleogeography and Paleotectonics from $\mathrm{U}-\mathrm{Pb}$ of detrital zircons in Mesozoic strata of the Colorado Plateau, USA: International Journal of Earth Sciences, v. 99, p. 1247-1265. 
Dickinson, W.R., Lawton, T.F., Pecha, M., Davis, S.J., Gehrels, G.E., and Young, R.A. ,2012, Provenance of the Paleogene Colton Formation (Uinta Basin) and Cretaceous-Paleogene provenance evolution in the Utah foreland: Evidence from $\mathrm{U}-\mathrm{Pb}$ ages of detrital zircons, paleocurrent trends, and sandstone petrofacies: Geosphere, v. 8, p. 854-880.

Dilek, Y., and Moores, E.M., 1999, A Tibetan model for the early Tertiary western United States: Geological Society of London Journal, v. 156, p. 929-941.

Dobson, K. J., Stuart, F. M., \& Dempster, T. J., 2008, U and Th zonation in Fish Canyon Tuff zircons: Implications for a zircon (U-Th)/He standard, Geochimica et Cosmochimica Acta, v. 72, p. $4745-4755$.

Doebbert, A.C., Carroll, A.R., and Johnson, C., 2012, The sandstone-derived provenance record of the Gualala basin, northern California, USA: Journal of Sedimentary Research, v. 82, p. 841-858.

Druschke, P., Hanson, A.D., Wells, M.L., Gehrels, G.E., and Stockli, D., 2011, Paleogeographic isolation of the Cretaceous to Eocene Sevier hinterland, east-central Nevada: Insights from $\mathrm{U}-\mathrm{Pb}$ and $(\mathrm{U}-\mathrm{Th}) / \mathrm{He}$ detrital zircon ages of hinterland strata: Geological Society of America Bulletin, v. 123, p. 1141-1160.

Ducea, M., 2001, The California arc: thick granitic batholiths, eclogitic residues, lithosphere scale thrusting, and magmatic flare-ups: GSA Today, v. 11, p. 4-10.

Dumitru, T.A., 1990, Subnormal Cenozoic geothermal gradients in the extinct Sierra Nevada magmatic arc: Consequences of Laramide and post-Laramide shallow-angle subduction: Journal of Geophysical Research: Solid Earth, v. 95, p. 4925-4941.

Dumitru, T.A., Gans, P.B., Foster, D.A., and Miller, E.L., 1991, Refrigeration of the western Cordilleran lithosphere during Laramide shallow-angle subduction: Geology, v. 19, p. 11451148. 
Dumitru, T.A., Ernst, W.G., Wright, J.E., Wooden, J.L., Wells, R.E., Farmer, L.P., and Graham, S.A., 2013, Eocene extension in Idaho generated massive sediment floods into the Franciscan trench and into the Tyee, Great Valley, and Green River basins: Geology, v. 41, p. 187-190.

Engebretson, D.C., Cox, A., and Gordon, R.G., 1985, Relative Motions between Oceanic and Continental Plates in the Pacific Basin: Geological Society of America Special Paper 206, 59 p.

Erdman, M.E., Lee, C.A, Levander, A., and Jiang, H., 2016, Role of arc magmatism and lower crustal foundering in controlling elevation history of the Nevadaplano and Colorado Plateau: A case study of pyroxenitic lower crust from central Arizona, USA: Earth and Planetary Science Letters, v. 439, p. 48-57.

Ernst, W.G., 2010, Young convergent-margin orogens, climate, and crustal thickness - A Late Cretaceous-Paleogene Nevadaplano in the American Southwest?: Lithosphere, v. 2, p. $67-$ 75.

Fan, M., and Carrapa, B., 2014, Late Cretaceous-early Eocene Laramide uplift, exhumation, and basin subsidence in Wyoming: Crustal responses to flat slab subduction: Tectonics, v. 33, p. $509-529$.

Farley, K.A., Wolf, R.A., and Silver, L.T., 1996, The effects of long alpha-stopping distances on (U-Th)/He ages: Geochimica et Cosmochimica Acta, v. 60, p. 4223-4229.

Farley, K.A., 2000, Helium diffusion from apatite: General behavior as illustrated by Durango fluorapatite: Journal of Geophysical Research: v. 105, p. 2903-2914, doi:10.1029/1999JB900348.

Farley, K.A., 2002, (U-Th)/He dating: Techniques, calibrations, and applications: Reviews in Mineralogy and Geochemistry, v. 47, p. 819-844. 
Fayon, A.K., Tikoff, B., Kahn, M., and Gaschnig, R.M., 2017, Cooling and exhumation of the southern Idaho batholith: Lithosphere, v. 9, p. 299-314.

Fedo, C.M., Sicrombe, K.N., and Rainbird, R.H., 2003, Detrital zircon analysis of the sedimentary record: Reviews in Mineralogy \& Geochemistry, v. 53, p. 277-303.

Ferrill, D.A., Morris, A.P., Stamatakos, J.A., Waiting, D.J., Donelick, R.A., and Blythe, A.E., 2012, Constraints on exhumation and extensional faulting in southwestern Nevada and eastern California, USA, from zircon and apatite thermochronology: Lithosphere, v. 4, p. 6376.

Garver, J. I., Brandon, M. T., Roden-Tice, M., and Kamp, P. J., 1999, Exhumation history of orogenic highlands determined by detrital fission-track thermochronology: Geological Society, London, Special Publications, v. 154, p. 283-304.

Gibson, T.G., Bybell, L.M., and Owens, J.P., 1993, Latest Paleocene lithological biotic events in neritic deposits from southwestern New Jersey: Paleoceanography, v. 8, p. 495-514.

Glazner, A.F., Lee, J. Bartley, J.M., Coleman, D.S., Kylander-Clark, A., Greene, D.C., and Le, K., 2005, Large dextral offset across Owens Valley, California from 148 Ma to 1872 A.D., in Stevens, C. and Cooper, J., eds., Western Great Basin Geology: Pacific Section, SEPM, v. 99, p. 1-35.

Gorynski, K.E., Stockli, D.F., and Walker, J.D., 2013, Thermochronometrically constrained anatomy and evolution of a Miocene extensional accommodation zone and tilt domain boundary: The southern Wassuk Range, Nevada: Tectonics, v. 32, p. 516-539.

Graymer, R.W., Jones, D.L., and Brabb, E.E., 1994, Preliminary geologic map emphasizing bedrock formations in Contra Costa County, California: U.S. Geological Survey, OpenFile Report 94-622, scale 1:75,000. 
Guenthner, W. R., Reiners, P. W., Ketcham, R. A., Nasdala, L., and Giester, G., 2013, Helium diffusion in natural zircon: Radiation damage, anisotropy, and the interpretation of zircon (UTh)/He thermochronology: American Journal of Science, v. 313, p. 145-198.

Hamilton, W., and Myers, W.B., 1967, The nature of batholiths. U. S. Geological Survey Professional Paper 554C, 30 p.

Haxel, G.B., Tosdal, R.M., May, D.J., and Wright, J.E., 1984, Latest Cretaceous and early Tertiary orogenesis in south-central Arizona: Thrust faulting, regional metamorphism, and granitic plutonism: Geological Society of America Bulletin, v. 95, p. 631-653.

Henry, C.D., and Faulds, J.E., 2010, Ash-flow tuffs in the Nine Hill, Nevada, paleovalley and implications for tectonism and volcanism of the western Great Basin, USA: Geosphere, v. 6, p. 339-369.

Henry, C.D., Hinz, N.H., Faulds, J.E., Colgan, J.P., John, D.A., Brooks, E.R., Cassel, E.J., Garside, L.J., Davis, D.A., and Castor, S.B., 2012, Eocene-Early Miocene paleotopography of the Sierra Nevada-Great Basin-Nevadaplano based on widespread ash-flow tuffs and paleovalleys: Geosphere, v. 8, p. 1-27.

Henry, C.D., and John, D.A., 2013, Magmatism, ash-flow tuffs, and calderas of the ignimbrite flareup in the western Nevada volcanic field, Great Basin, USA: Geosphere, v. 9, p. 9511008.

Hessler, A.M., Zhang, J., Covault, J., and Ambrose, W., 2017, Continental weathering coupled to Paleogene climate changes in North America: Geology, v. 45, p. 911-914.

Hodges, K.V. and Walker, J.D., 1992, Petrologic Constraints on the Unroofing History of the Funeral Mountain Metamorphic Core Complex, California: Journal of Geophysical Research, v. 95, p. $8437-8445$. 
Hoisch, T.D., and Simpson, C., 1993, Rise and tilt of metamorphic rocks in the lower plate of a detachment fault in the Funeral Mountains, Death Valley, California: Journal of Geophysical Research: Solid Earth, v. 98, p. 6805-6827.

Horne, A.M., Matthijs, C.S., Hodges, K.V., Tripathy-Lang, A., and Hourigan, J.K., 2016, Integrated single crystal laser ablation $\mathrm{U} / \mathrm{Pb}$ and (U-Th)/He dating of detrital accessory minerals - Proof-of-concept studies of titanites and zircons from the Fish Canyon tuff: Geochimica et Cosmochimica Acta, v. 178, p. 106-123.

Horton T.W., Sjostrom, D.J., Abruzzese, M.J., Poage, M.A., Waldbauer, J.R., Hren, M., Wooden, J., and Chamberlain, C.P., 2004, Spatial and temporal variation of Cenozoic surface elevation in the Great Basin and Sierra Nevada: American Journal of Science, v. 304, p. 862888.

Hourigan, J. K., Reiners, P. W., and Brandon, M. T., 2005, U-Th zonation-dependent alphaejection in (U-Th)/He chronometry: Geochimica et Cosmochimica Acta, v. 69, p. 3349-3365.

House, M.A., Wernicke, B.P., Farley, K.A., and Dumitru, T.A., 1997, Cenozoic thermal evolution of the central Sierra Nevada, California, from (U-Th)/He thermochronometry: Earth and Planetary Science Letters, v. 151, p. 167-179.

House, M.A., Wernicke, B.P., and Farley, K.A., 2001, Paleo-geomorphology of the Sierra Nevada, California, from (U-Th)/He ages in apatite: American Journal of Science, v. 301, p. 77-102.

Howard, J.L., McLean, H., and Zink, L.L., 1995, Conglomerates of the upper middle Eocene to lower Miocene Sespe Formation along the Santa Ynez fault: Implications for the geologic history of the eastern Santa Maria basin area, California: U.S. Geological Survey Bulletin 1995-H, 37 p. 
Howard, J.L., 2000, Provenance of quartzite clasts in the Eocene-Oligocene Sespe Formation: Paleogeographic implications for southern California and the ancestral Colorado River: Geological Society of America Bulletin, v. 112, p. 1635-1649.

Howell, D.G., and Vedder, J.G., 1978, Late Cretaceous paleogeography of the Salinian block, California, in Howell, D.G., and McDougall, K.A., eds., Mesozoic paleogeography of the western United States: Society of Economic Paleontologists and Mineralogists Pacific Coast Paleogeography Symposium 2, p. 523-534.

Humphreys, E.D., 1995, Post-Laramide removal of the Farallon slab, western United States: Geology, v. 23, p. 987-990.

Ingersoll, R.V., 1979, Evolution of the Late Cretaceous forearc basin, northern and central California: Geological Society of America Bulletin, v. 90, p. 813-826.

Ingersoll, R.V., 1983, Petrofacies and provenance of late Mesozoic forearc basin, northern and central California: American Association of Petroleum Geologists Bulletin, v. 67, p. 11251142.

Jackson, S.E., Pearson, N.J., Griffin, W.L., and Belousova, E.A., 2004, The application of laser ablation-inductively coupled plasma-mass spectrometry to in situ U-Pb zircon geochronology: Chemical Geology, v. 211, p. 47-69.

Jacobson, C.E., Grove, M., Stamp, M.M., Vućić, A., Oyarzabal, F.R., Haxel, G.B., Tosdal, R.M., and Sherrod, D.R., 2002, Exhumation history of the Orocopia Schist and related rocks in the Gavilan Hills area of southeasternmost California, in Barth, A., ed., Contributions to Crustal Evolution of the Southwestern United States: Geological Society of America Special Paper 365, p 129-154. ućí

Jacobson, C.E., Grove, M., Vućić, A., Pedrick, J.N., and Ebert, K.A., 2007, Exhumation of the Orocopia Schist and associated rocks of southeastern California: Relative roles of erosion, 
synsubduction tectonic denudation, and middle Cenozoic extension in Cloos, M., Carlson, W.D., Gilbert, M.C., Liou, J.G., and Sorensen, S.S., eds., Convergent Margin Terranes and Associated Regions: A Tribute to W.G. Ernst: Geological Society of America Special Paper 419, p. 1-37.

Jacobson, C.E., Grove, M., Pedrick, J.N., Barth, A.P., Marsaglia, K.M., Gehrels, G.E., and Nourse, J.A., 2011, Late Cretaceous-early Cenozoic tectonic evolution of the southern California margin inferred from provenance of trench and forearc sediments: Geological Society of America Bulletin, v. 123, p. 485-506.

Jennings, C.W., 1958, Geologic map of California, Olaf P. Jenkins edition, San Luis Obispo Sheet: California Div. of Mines.

Jiao, Z.S. and Fritsche, A.E., 1994, Depositional environments and paleogeography of the Coldwater Formation, upper Sespe Creek, Ventura County, California: SEPM, Pacific Section, Guidebook, v. 74, p. 57-78.

Jones, C.H., Farmer, G.L., and Unruh, J., 2004, Tectonics of Pliocene removal of lithosphere of the Sierra Nevada, California: Geological Society of America Bulletin, v.116, p. 1408-1422. Kanter, L.R., 1988, Paleolatitude of the Butano Sandstone, California, and its implications for the kinematic histories of the Salinian terrane and the San Andreas fault: Journal of Geophysical Research: Solid Earth, v. 93, p. 11699-11710.

Kidder, S., Ducea, M., Gehrels, G., Patchett, P.J., and Vervoort, J., 2003, Tectonic and magmatic development of the Salinian Coast Ridge belt, California: Tectonics, v. 22.

Kies, R.P., and Abbott, P.L., 1983, Rhyolite clast populations and tectonics in the California continental borderland: Journal of Sedimentary Petrology, v. 53, p. 461-476.

Kimbrough, D.L., Smith, D.P., Mahoney, B.J., Moore, T.E., Grove, M., Gastil, R.G., OrtegaRivera, A., and Fanning, C.M., 2001, Forearc-basin sedimentary response to rapid Late 
Cretaceous batholith emplacement in the Peninsular Ranges of southern and Baja California: Geology, v. 29, p. 491-494.

Knox, R.W.O., 1998, Kaolinite influx within Paleocene-Eocene boundary strata of western Europe: Newsletters on Stratigraphy, v. 36, p. 49-53.

Koch, P.L., Zachos, J.C., and Gingerich, P.D., 1992, Correlation between isotope records in marine and continental carbon reservoirs near the Palaeocene/Eocene boundary: Nature, v. 358, p. 319-322.

Kosler, J., Fonneland, H., Sylvester, P., Tubrett, M., and Pederson, R., 2002, U-Pb dating of detrital zircons for sediment provenance studies - a comparison of laser ablation ICPMS and SIMS techniques: Chemical Geology, v. 182, p. 605-618.

Lechler, A.R. and Niemi, N.A., 2011, Sedimentologic and isotopic constraints on the Paleogene paleogeography and paleotopography of the southern Sierra Nevada, California: Geology, v. 39, p. 379-382

Lee, J., Stockli, D.F., Owen, L.A., Finkel, R.C., and Kislitsyn, R., 2009, Exhumation of the Inyo Mountains, California: Implications for the timing of extension along the western boundary of the Basin and Range Province and distribution of dextral fault slip rates across the eastern California shear zone: Tectonics, v. 28, TC100, doi: 10.1029/2008TC002295.

Lerch, D.W., Klemperer, S.L., Glen, J.M.G., Ponce, D.A., Miller, E.L., and Colgan, J.P., 2007, Crustal structure of the northwestern Basin and Range Province and its transition to unextended volcanic plateaus: Geochemistry, Geophysics, Geosystems, v. 8, p. 1-21.

Lindgren, W., 1911, The tertiary gravels of the Sierra Nevada of California: U.S. Geological Survey Professional Paper, v. 73, 226 p.

Lipman, P.W., 1992, Magmatism in the Cordilleran United States; Progress and problems, in Burchfield, B.L., Zoback, M.L., and Lipman, P., eds., The Cordilleran Orogen: Conterminous 
U.S.: Boulder Colorado, Geological Society of America, The Geology of North America, v. G-3, p. 107-168.

Liu, L., Gurnis, M., Seton, M., Saleeby, J., Müller, R.D., and Jackson, J.M., 2010, The role of oceanic plateau subduction in the Laramide orogeny: Nature Geoscience, v. 3, p. 353-357.

Long, S.P., 2012, Magnitudes and spatial patterns of erosional exhumation in the Sevier hinterland, eastern Nevada and western Utah, USA: Insights from a Paleogene paleogeologic map: Geosphere, v. 8, p. 881-901.

Long, S.P., Thomson, S.N., Reiners, P.W., and Di Fiori, R.V., 2015, Synorogenic extension localized by upper-crustal thickening: An example from the Late Cretaceous Nevadaplano: Geology, v. 43, p. 351-354.

Long, S.P. and Soignard, E., 2016, Shallow-crustal metamorphism during Late Cretaceous anataxis in the Sevier hinterland plateau: Peak temperature conditions from the Grant Range, eastern Nevada, U.S.A.: Lithosphere, v. 8, p. 150-164.

Mahan, K.H., Guest, B., Wernicke, B., and Niemi, N.A., 2009, Low-temperature thermochronologic constraints on the kinematic history and spatial extent of the Eastern California shear zone: Geosphere, v. 5, p. 483-495.

Maheo, G., Saleeby, J., Saleeby, Z., and Farley, K.A., 2009, Tectonic control on southern Sierra Nevada topography, California: Tectonics, v. 28, 22 p.

Mattinson, J.M., 1990, Petrogenesis and evolution of the Salinian magmatic arc, in Anderson, J.L., ed., The nature and origin of Cordilleran magmatism: Geological Society of America Memoir 174, p. 237-250.

McDougall, K., 1998, Paleogene foraminifera of the Gualala Block and their relation to local and global events, in Elder, W.P., ed., Geology and Tectonics of the Gualala Block, Northern California: Pacific Section, SEPM (Society for Sedimentary Geology, Book 84. p. 169-188. 
McDowell, F.W., Roldán-Quintana, J., and Connelly, J. N., 2001, Duration of Late Cretaceousearly Tertiary magmatism in east-central Sonora, Mexico. Geological Society of America Bulletin, v. 113, p. 521-531.

McLaughlin, R.J., Clark, J.C., Brabb, E.E., Helley, E.J., and Wentworth, C.M., 2004, Geologic map of the Loma Prieta region, California: U.S. Geological Survey Professional Paper 1550-E, 3 plates.

McLean, N.M., Bowring, J.F., and Gehrels, G., 2016, Algorithms and software for U-Pb geochronology by LA-ICPMS: Geochemistry, Geophysics, Geosystems, v. 17, p. 2480-2496.

McQuarrie, N. and Wernicke, B.P., 2005, An animated tectonic reconstruction of southwestern North America since 36 Ma: Geosphere, v. 1, p. 147-172.

Michael, N.A., Carter, A., Whittaker, A.C., and Allen, P.A., 2014, Erosion rates in the source region of an ancient sediment routing system: comparison of depositional volumes with thermochronometric estimates: Journal of the Geological Society, London, v. 171, p. 401412.

Milam, R.W., 1985, Biostratigraphy and sedimentation of the Eocene and Oligocene Kreyenhagen Formation, central California [Ph.D. thesis]: Stanford, Stanford University, 240 p.

Miller, M.G., and Friedman, R.M., 1999, Early Tertiary magmatism and probable Mesozoic fabrics in the Black Mountains, Death Valley, California: Geology, v. 27, p. 19-22.

Miller, C.M., 2012, Detrital thermochronology of the Alpine foreland basin in Central Switzerland: Insights into tectonic and erosion history of the North Central Alps: [M.S. Thesis]: Lawrence, Kansas, University of Kansas, 162 p.

Mix, H.T., Mulch, A., Kent-Corson, M.L., and Chamberlain, C.P., 2011, Cenozoic migration of topography in the North American Cordillera: Geology, v. 39, p. 87-90. 
Mix, H.T., Ibarra, D.E., Mulch, A., Graham, S.A., and Chamberlain, C P., 2016, A hot and high Eocene Sierra Nevada. Geological Society of America Bulletin, v. 128, p. 531-542.

Molnar, P., and England, P., 1990, Late Cenozoic uplift of mountain ranges and global climate change: chicken or egg?: Nature, v. 346, p. 29-34.

Molnar, P., 2010, Deuterium and oxygen isotopes, paleoelevations of the Sierra Nevada, and Cenozoic climate: Geological Society of America Bulletin, v. 122, p. 1106-1115.

Moxon, I.W., and Graham, S.A., 1987, History and controls of subsidence in the Late Cretaceous-Tertiary Great Valley forearc basin, California: Geology, v. 15, p. 626-629.

Moxon, I.W., 1988, Sequence stratigraphy of the Great Valley basin in the context of convergent margin tectonics, in Graham, S.A., and Olson, H.C., eds., Studies of the geology of the San Joaquin basin: Los Angeles, Society of Economic Paleontologists and Mineralogists, Pacific Section, Field Trip Guidebook, v. 60, p. 3-28.

Mulch, A., Graham, S.A., and Chamberlain, C.P., 2006, Hydrogen isotopes in Eocene river gravels and paleoelevation of the Sierra Nevada: Science, v. 313, p. 87-89.

Nadin, E.S., Saleeby, J., and Wong, M., 2016, Thermal evolution of the Sierra Nevada batholith, California, and implications for strain localization: Geosphere, v. 12, p. 377-399.

Nasdala, L., Reiners, P.W., Garver, J.I., Kennedy, A.K., Stern, R.A., Balan, E., and Wirth, R., 2004, Incomplete retention of radiation damage in zircon from Sri Lanka: American Mineralogist, v. 89, p. 219-231.

Nilsen, T.H., and Clark, S.H., 1975, Sedimentation and Tectonics in the Early Tertiary Continental Borderland of Central California: Geological Survey Professional Paper 925, 64 p. 
Peterson, G.L. and Abbott, P.L., 1979, Mid-Eocene climatic change, southwestern California and northwestern Baja California: Palaeogeography, Palaeoclimatology, Palaeoecology, v. 26, p. 73-87.

Poage, M.A., and Chamberlain, C.P., 2002, Stable isotopic evidence for a pre-Middle Miocene rain shadow in the western Basin and Range: Implications for the paleotopography of the Sierra Nevada: Tectonics, v. 21, 4 p.

Pullen, A., Ibáñez-Mejía, M., Gehrels, G.E., Ibáñez-Mejía, J.C., and Pecha, M., 2014, What happens when $n=1000$ ? Creating large-n geochronological datasets with LA-ICP-MS for geologic investigations: Journal of Analytical Atomic Spectrometry, v. 29, p. 971-980.

Rahl, J.M., Reiners, P.W., Campbell, I.H., Nicolescu, S., and Allen, C.M., 2003, Combined single-grain (U-Th)/He and U/Pb dating of detrital zircons from the Navajo Sandstone, Utah: Geology, v. 31, p. 761-764.

Rahl, J. M., Ehlers, T. A., and van der Pluijm, B. A., 2007, Quantifying transient erosion of orogens with detrital thermochronology from syntectonic basin deposits: Earth and Planetary Science Letters, v. 256, p. 147-161.

Reiners, P.W., and Farley, K.A., 2001, Influence of crystal size on apatite (U-Th)/He thermochronology: an example from the Bighorn Mountains, Wyoming. Earth and Planetary Science Letters, v. 188, p. 413-420.

Reiners, P.W., Farley, K.A., and Hickes, H.J., 2002, He diffusion and (U-Th)/He thermochronometry of zircon: Initial results from Fish Canyon Tuff and Gold Butte: Tectonophysics, v. 349, p. 247-308.

Reiners, P.W., Spell, T.L., Nicolescu, S., and Zanetti, K.A., 2004, Zircon (U-Th)/He thermochronometry: He diffusion and comparisons with 40Ar/39Ar dating: Geochimica et Cosmochimica Acta, v. 68, p. 1857-1887. 
Reiners, P.W., 2005, Zircon (U-Th)/He Thermochronometry: Reviews in Mineralogy \& Geochemistry, v. 58, p. 151-179.

Reiners, P.W., Campbell, I.H., Nicolescu, S., Allen, C.M., Hourigan, J.K., Garver, J.I., Mattinson, J.M., and Cowan, D.S., 2005, (U-Th)/(He-Pb) Double dating of detrital zircons: American Journal of Science, v. 305, p. 259-311.

Robert, C., and Chamley, H., 1991, Development of early Eocene warm climates, as inferred from clay mineral variations in oceanic sediments: Palaeogeography, Palaeoclimatology, Palaeoecology, v. 89, p. 315-331.

Ross, D.C., 1978, The Salinian block - a Mesozoic granitic orphan in the California coast ranges, in Mesozoic paleogeography of the western United States: SEPM Pacific Sec., Pacific Coast Paleogeography Symposium 2, p. 509-522.

Ruiz, G.M.H., Seward, D., and Winkler, W., 2004, Detrital thermochronology-a new perspective on hinterland tectonics, an example from the Andean Amazon Basin, Ecuador: Basin Research, v. 16, p. 413-430.

Saleeby, J., Farley, K.A., Kistler, R.W., and Fleck, R.J, 2007, Thermal evolution and exhumation of deep-level batholithic exposures, southernmost Sierra Nevada, California, in Cloos, M., Calrson, W.D., Gilbert, M.C., Liou, J.G., and Sorensen, S.S., eds., Convergent Margin Terranes and Associated Regions: A Tribute to W.G. Ernst: Geological Society of America Special Paper 419, P. 39-66.

Saylor, J.E., Stockli, D.F., Horton, B.K., Nie, J., and Mora, A., 2012, Discriminating rapid exhumation from syndepostional volcanism using detrital zircon double dating: Implications for the tectonic history of the Eastern Cordillera, Colombia, GSA Bulletin, v. 124, p. 762779. 
Schemmann, K., Unruh, J.R., and Moores, E.M., 2008, Kinematics of Franciscan Complex exhumation: New insights from the geology of Mount Diablo, California: Geological Society of America Bulletin, v. 120, p. 543-555.

Schmidt, C.J., Chase, R.B., and Erslev, E.A., 1993, Laramide basement deformation in the Rocky Mountain foreland of the western United States: Geological Society of America Special Paper 280, V. 280, p. 1993.

Schmitz, M.D., and Bowring, S.A., 2001, U-Pb zircon and titanite systematics of the Fish Canyon Tuff: An assessment of high-precision U-Pb geochronology and its application to young volcanic rocks: Geochimica et Cosmochimica Acta, v. 65, p. 2571-2587.

Schmitz, B., Pujalte, V., and Nunez-Betelu, K., 2001, Climate and sea-level perturbations during the Initial Eocene Thermal Maximum: Evidence from siliciclastic units in the Basque Basin (Ermua, Zumaia and Trabakua Pass), northern Spain: Palaeogeography, Palaeoclimatology, Palaeoecology, v. 165, p. 299-320.

Schott, R.C., and Johnson, C.M., 1998, Late Cretaceous to Eocene Gualala basin provenance constraints from conglomerate clasts: implications for the origin and early evolution of the Salinian block, in Elder, W.P., ed., Geology and Tectonics of the Gualala Block, Northern California: SEPM, Pacific Section, Book 84. p. 75-94.

Seiders, V.M., and Cox, B.T., 1992, Place of origin of the Salinian block, California, as based on clast compositions of Upper Cretaceous and lower Tertiary conglomerates: U.S. Geological Survey Professional Paper 1526, 80 p.

Seton, M., et al., 2012, Global continental and ocean basin reconstructions since 200 Ma: Earth-Science Reviews, v. 113, p. 212-270.

Sharman, G.R., Graham, S.A., Grove, M., and Hourigan, J.K., 2013, A reappraisal of the early slip history of the San Andreas fault, central California, USA: Geology, v. 41, p. 727-730. 
Sharman, G.R., Graham, S.A., Grove, M., Kimbrough, D.L., and Wright, J.E., 2015, Detrital zircon provenance of the Late Cretaceous-Eocene California forearc: Influence of Laramide low-angle subduction on sediment dispersal and paleogeography: Geological Society of America Bulletin, v. 127, p. 38-60.

Sharman, G.R., Covault, J.A., Stockli, D.F., Wroblewski, A.F.J., and Bush, M.A., 2017, Early Cenozoic drainage reorganization of the United States Western Interior-Gulf of Mexico sediment routing system: Geology, v. 45, p. 187-190.

Short, W.R., Jr., 1986, Geology of the Santa Teresa Hills, Santa Clara County, California [M.S. thesis]: San Jose, California State University, 112 p.

Silver, L.T., and Chappell, B.W., 1988, The Peninsular Ranges Batholith: an insight into the evolution of the Cordilleran batholiths of southwestern North America: Earth and Environmental Science Transactions of The Royal Society of Edinburgh, v. 79, p. 105-121.

Sims, J.D., Fox Jr, K.F., Bartow, J.A., and Helley, E.J, 1973, Preliminary Geologic Map of Solano County and parts of Napa, Contra Costa, Marin, and Yolo Counties, California: U.S. Geological Survey Miscellaneous Field Studies, MF-484, scale 1:62,500.

Sircombe, K.N., and Stern, R.A., 2002, An investigation of artificial biasing in detrital zircon U$\mathrm{Pb}$ geochronology due to magnetic separation in sample preparation: Geochimica et Cosmochimica Acta, v. 66, p. 2379-2397.

Sláma, J., Košler, J., Condon, D.J., Crowley, J.L., Gerdes, A., Hanchar, J.M., Horstwood, M.S. A., Morris, G.A., Nasdala, L., Norberg, N., Schaltegger, U., Schoene, B., Tubrett, M.N., and Whitehouse, M.J., 2008, Plešovice zircon-a new natural reference material for U-Pb and $\mathrm{Hf}$ isotopic microanalysis: Chemical Geology, v. 249, p. 1-35.

Smith, M.E., Carroll, A.R., and Mueller, E.R., 2008, Elevated weathering rates in the Rocky Mountains during the early Eocene climatic optimum: Nature Geoscience, v. 1, p. 370-374. 
Smith, M.E., Carroll, A.R., Jicha, B.R., Cassel, E.J., and Scott, J.J., 2014, Paleogeographic record of Eocene Farallon slab rollback beneath western North America: Geology, v. 42, p. 1039-1042.

Snell, K.E., Koch, P.L., Druschke, P., Foreman, B.Z., and Eiler, J.M., 2014, High elevation of the 'Nevadaplano' during the Late Cretaceous: Earth and Planetary Science Letters, v. 386, p. 52-63.

Sousa, F.J., Saleeby, J., Farley, K.A., Unruh, J.R., and Lloyd, M.K., 2017, The southern Sierra Nevada pediment, central California: Geosphere, v. 13, p. 82-101.

Stauffer, P.H., 1967, Grain-flow deposits and their implications, Santa Ynez Mountains, California: Journal of Sedimentary Research, v. 37, p. 487-508.

Stockli, D.F., Surpless, B.E., and Dumitru, T.A., 2002, Thermochronological constraints on the timing and magnitude of Miocene and Pliocene extension in the central Wassuk Range, western Nevada: Tectonics, v. 21, p. 10-1 - 10-17.

Stockli, D.F., T.A. Dumitru, M.O. McWilliams, and K.A. Farley, 2003, Cenozoic tectonic evolution of the White Mountains, California and Nevada: Geological Society of America Bulletin, v. 115, p. 788-816.

Surpless, B.E., Stockli, D.F., Dumitru, T.A., and Miller, E.L., 2002, Two-phase westward encroachment of Basin and Range extension into the northern Sierra Nevada: Tectonics, v. 21, p. 2-1 - 2-13.

Sullivan, R., and Sullivan, M.D., 2012, Sequence stratigraphy and incised valley architecture of the Domengine Formation, Black Diamond Mines Regional Preserve and the southern Sacramento basin, California, U.S.A.: Journal of Sedimentary Research, v. 82, p. 781800, doi: $10.2110 /$ jsr.2012.66. 
Sylvester, A.G., and Darrow, A.C., 1979, Structure and neotectonics of the western Santa Ynez fault system in southern California: Tectonophysics, v. 52, p. 389-405.

Thiry, M., and Dupuis, M., 2000, Use of clay minerals for paleoclimatic reconstructions: Limits of the method with special reference to the Paleocene-lower Eocene interval: GFF, v. 122, p. $166-167$.

Thompson, T.J., 1988, Outer-fan lobes of the lower to middle Eocene Juncal Formation, San Rafael Mountains, California, in Filewicz, M.V., and Squires, R.L., eds., Paleogene Stratigraphy, West Coast of North America: Los Angeles, Pacific Section, SEPM (Society for Sedimentary Geology), v. 58, p. 113-127.

Throckmorton, C.K., 1988, Geology and paleontology of the Tesla Formation, Alameda and San Joaquin counties, central California: U.S. Geological Survey Open File ReportN 88-59, 104 p. Torres, M.A. and Gaines, R.R., 2013, Paleoenvironmental and Paleoclimatic Interpretations of the Late Paleocene Goler Formation, Southern California, USA, Based on Paleosol Geochemistry: Journal of Sedimentary Research, v. 83, p. 591-605.

Turner, D.L., 1970, Potassium-argon dating of Pacific Coast foraminiferal stages, in Bandy, O.L., ed., Radiometric Dating and Paleontologic Zonation: Geological Society of America Special Paper, v. 124, p. 91-129.

Vedder, J.G., 1972, Revision of stratigraphic names for some Eocene formations in Santa Barbara and Ventura counties, California: U.S. Geological Survey Bulletin 1374-D, p. D1-D12.

Vedder, J.G. and McLean, H., 1989, Geologic map of Miranda Pine Mtn. quadrangle and part of Taylor Canyon quadrangle, California: U.S. Geological Survey Open-File Report 89-469, scale 1:24,000. 
Vedder, J.G., McLean, H., Stanley, R.G., and Wiley, T.J., 1991, Paleogeographic implications of an erosional remnant of Paleogene rocks southwest of the Sur-Nacimiento fault zone, southern Coast Ranges, California: Geological Society of America Bulletin 103, p. 941-952.

Vermeesch, P., 2004, How many grains are needed for a provenance study?: Earth and Planetary Science Letters, v. 224, p. 441-451.

Vermeesch, P., 2012, On the visualization of detrital age distributions, Chemical Geology: v. 312, p. 190-194.

Vermeesch, P., 2013, Multi-sample comparison of detrital age distributions: Chemical Geology, v. 341, p. $140-146$.

Vermeesch, P., Resentini, A., and Garzanti, E., 2016, An R package for statistical provenance analysis: Sedimentary Geology, v. 336, p. 14-25.

Wakabayashi, J., and Sawyer, T.L., 2001, Stream incision, tectonics, uplift and evolution of topography of the Sierra Nevada, California: The Journal of Geology, v. 109, p. 539-562.

Walker, J.D., Bidgoli, T.S., Didericksen, B.D., Stockli, D.F., and Andrew, J.E., 2014, Middle Miocene to recent exhumation of the Slate Range, eastern California, and implications for the timing of extension and the transition to transtension: Geosphere, v. 10, p. 276-291.

Wang, C.Y., Campbell, I.H., Reiners, P.W., and Allen, C.M., 2014, Detrital zircon U-Pb-He double dating: A method of quantifying long- and short-term exhumation rates in collisional orogens: Science China Earth Sciences, v. 57, p. 2702-2711.

Wells, M.L., Dallmeyer, R.D., and Allmendinger, R.W., 1990, Late Cretaceous extension in the hinterland of the Sevier thrust belt, northwestern Utah and southern Idaho: Geology, v. 18, p. 929-933.

Wells, M.L., 1997. Alternating contraction and extension in the hinterlands of orogenic belts: an example from the Raft River Mountains: Utah. Geol. Soc. Am. Bull. 109, p. 107-126. 
Wells, M.L. and Hoisch, T.D., 2008, The role of mantle delamination in widespread Late Cretaceous extension and magmatism in the Cordilleran orogen, western United States: Geological Society of America Bulletin, v. 120, p. 515-530.

Wentworth, C.M., Jones, D.L., and Brabb, E.E., 1998, Geology and regional correlation of the Cretaceous and Paleogene rocks of the Gualala block, California in Elder, W.P., ed., Geology and tectonics of the Gualala Block, Northern California: Pacific Section, Society of Economic Paleontologists and Mineralogists of western North America: U.S. Geological Survey Bulletin 18, 26 p.

Wernicke, B., Clayton, R.W., Ducea, N.N., Jones, C.H., Park, S.K., Ruppert, S.D., Saleeby, J.B., Snow, J.K., Squires, L.J., Fliedner, M.M., Jiracek, G.R., Keller, G.R., Klemperer, S.L., Luetgert, J.H., Malin, P.E., Miller, K.C., Mooney, W.D., Oliver, H.W., and Phinney, R.A., 1996, Origin of high mountains in the continents: the southern Sierra Nevada: Science, v. 271, p. 190-193.

Whipple, K.X., 2009, The influence of climate on the tectonic evolution of mountain belts: Nature geoscience, v. 2, p. 97-104.

Willett, S.D., Hovius, N., Brandon, M.T., and Fisher, D.M. eds., 2006, Tectonics, climate, and landscape evolution: Geological Society of America Special Paper 398.

Wilson, D.S., McCrory, P.A., and Stanley, R.G., 2005, Implications of volcanism in coastal California for the Neogene deformation history of western North America: Tectonics, v. 24, TC3008.

Wissink, G.K., Wilkinson, B.H., and Hoke, G.D., 2018, Pairwise sample comparisons and multidimensional scaling of detrital zircon ages with examples from the North American platform, basin, and passive margin settings: Lithosphere, v. 10, p. 478-491. 
Wood, D.J., and Saleeby, J.B., 1997, Late Cretaceous-Paleocene extensional collapse and disaggregation of the southernmost Sierra Nevada batholith: International Geology Review, v. 39, p. 973-1009.

Wolfe, J.A., Forest, C.E., and Molnar, P., 1998, Paleobotanical evidence of Eocene and Oligocene paleoaltitudes in midlatitude western North America: Geological Society of America Bulletin, v. 110, p. 664-678.

Wolfe, M.R., and Stockli, D.F., 2010, Zircon (U-Th)/He thermochronometry in the KTB drill hole, Germany, and its implications for bulk He diffusion kinetics in zircon: Earth and Planetary Science Letters, v. 295, p. 69-82.

Wotzlaw, J.F., Schaltegger, U., Frick, D.A., Dungan, M.A., Gerdes, A., and Günther, D., 2013, Tracking the evolution of large-volume silicic magma reservoirs from assembly to supereruption: Geology, v. 41,p. 867-870.

Xu, J., Stockli, D.F., and Snedden, J.W., 2017, Enhanced provenance interpretation using combined $\mathrm{U}-\mathrm{Pb}$ and $(\mathrm{U}-\mathrm{Th}) / \mathrm{He}$ double dating of detrital zircon grains from lower Miocene strata, proximal Gulf of Mexico Basin, North America: Earth and Planetary Science Letters, v. 475 , p. 44-57.

Yin, A., 2002, Passive-roof thrust model for the emplacement of the Pelona-Orocopia Schist in southern California, United States: Geology, v. 30, p. 183-186.

Yonkee, W.A., and Weil, A.B., 2015, Tectonic evolution of the Sevier and Laramide belts within the North American Cordillera orogenic system. Earth-Science Reviews: v. 150, p. 531-593.

Zachos, J., Pagani, M., Sloan, L., Thomas, E., and Billups, K., 2001, Trends, rhythms, and aberrations in global climate 65 Ma to present: Science, v. 292, p. 686-693.

Zachos, J.C., Dickens, G.R., and Zeebe, R.E., 2008, An early Cenozoic perspective on greenhouse warming and carbon-cycle dynamics: Nature, v. 451, p. 279-283. 
PAGE LEFT BLANK INTENTIONALLY 


\section{FIGURES}
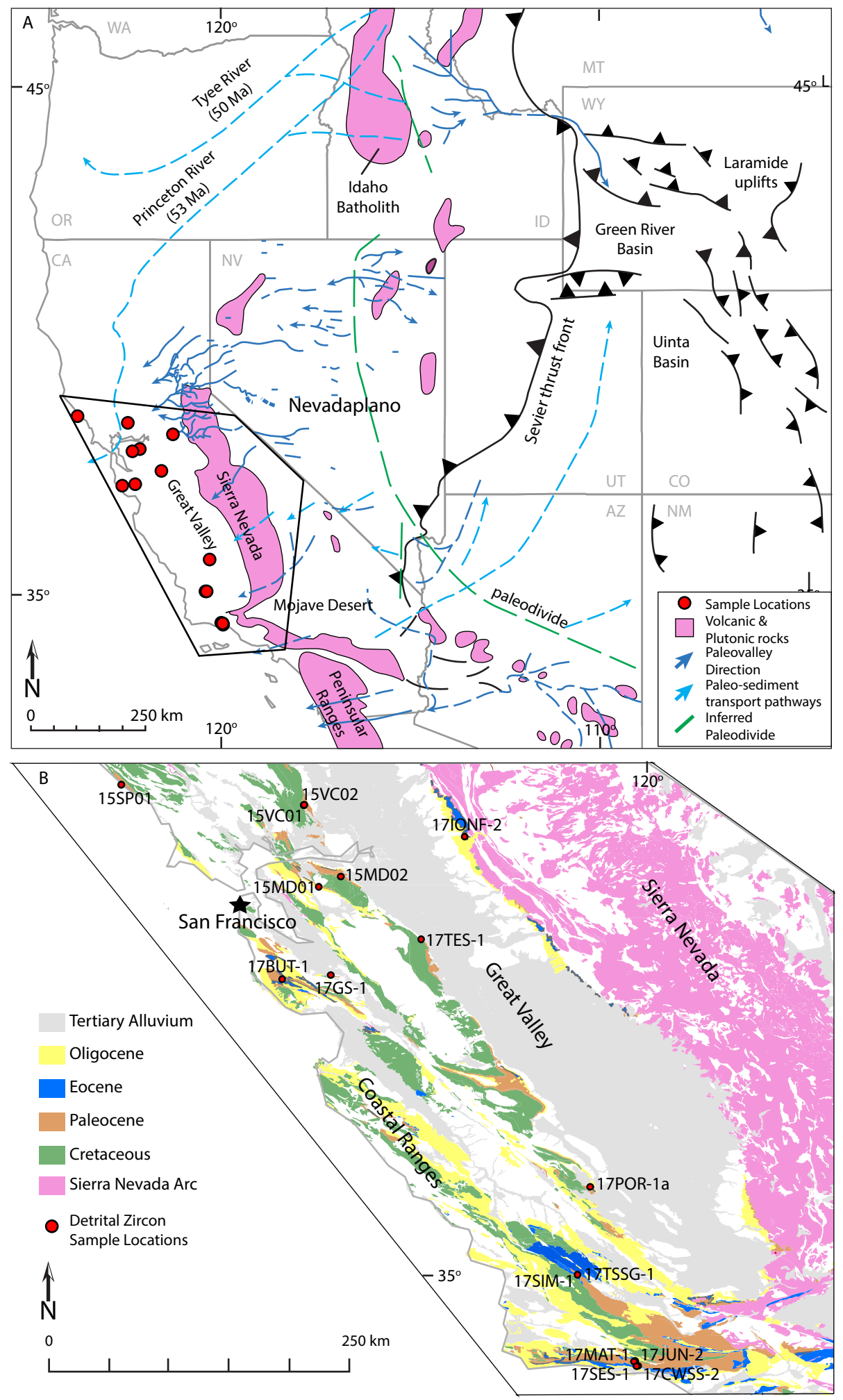
Figure 1. (A) Simplified map showing the major elements of the North America Cordillera in the western United States, including the Sevier and Laramide deformation fronts, magmatic arc, Great Valley forearc basin, metamorphic core complex belt, and the inferred positions of the early Cenozoic Nevadaplano and related paleodivides and paleodrainages. Study area in the Great Valley forearc is outlined in black and sample locations are shown as red circles. Modified from Wells and Hoisch (2008), Henry et al. (2012), and Dumitru et al. (2013). (B) Generalized geologic map showing ages of units in the study area and sample locations. Map data from compilation of Sharman et al. (2015). 


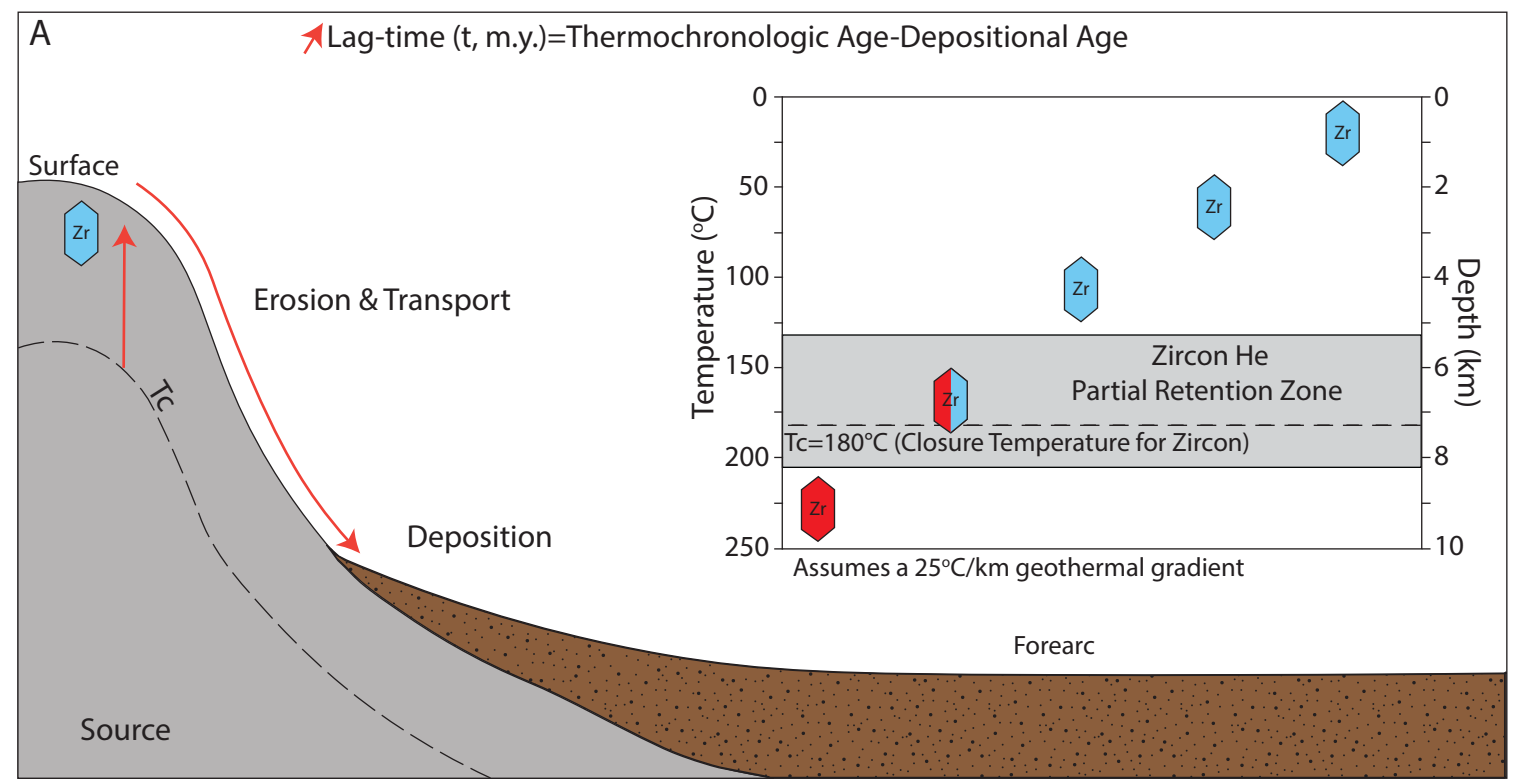

B

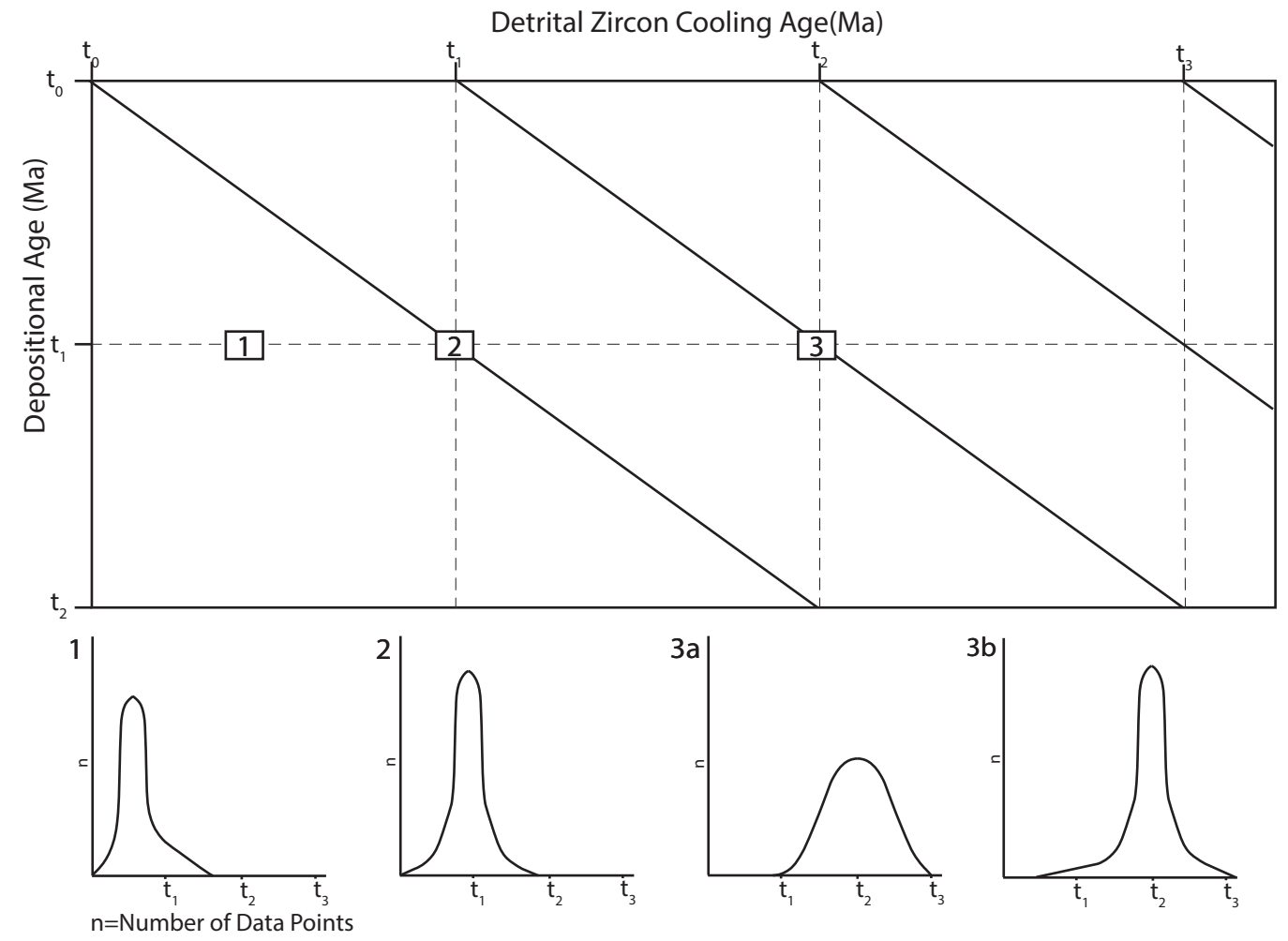


Figure 2. (A) Schematic diagram illustrating the processes from exhumation of a zircon grain to its ultimate deposition in a basin. Depositional lag-time is the difference in time between when the zircon is cooled above its closure temperature (Tc) and eroded, transported, and when it is deposited in the adjacent forearc (Ruiz et al., 2004; Saylor et al., 2012 Michael et al., 2014). Inset figure show the relationship between the depth and temperature and their roles in estimating the zircon closure temperature/partial retention zone (Reiners et al, 2002; Reiners et al., 2004; Wolfe and Stockli, 2010). (B) Graphs illustrate depositional lag-times and related cooling age distributions with 3 different positions on the plot explained in KDE graphs below. Box 1 indicates the zircon is post-depositionally reset and the ZHe age is younger than the depositional age. Time 2 indicates a short lag-time scenario, where the depositional age and cooling age are the same and the lag-time is $\sim 0$. This is further supported by the peak pattern in the KDE for time 2 below, suggesting a quick and significant cooling over that interval. Times $3 \mathrm{a}$ and $3 \mathrm{~b}$ are presented to show variations in cooling patterns that can be associated with lag-times. Time 3 shows the cooling age is older than the depositional age, resulting in a longer lag-time $(>0)$. Diagram 3a shows a protracted cooling history over this interval, while $3 \mathrm{~b}$ is also possible, where a long lag-time is associated with an earlier pulse of rapid cooling. 


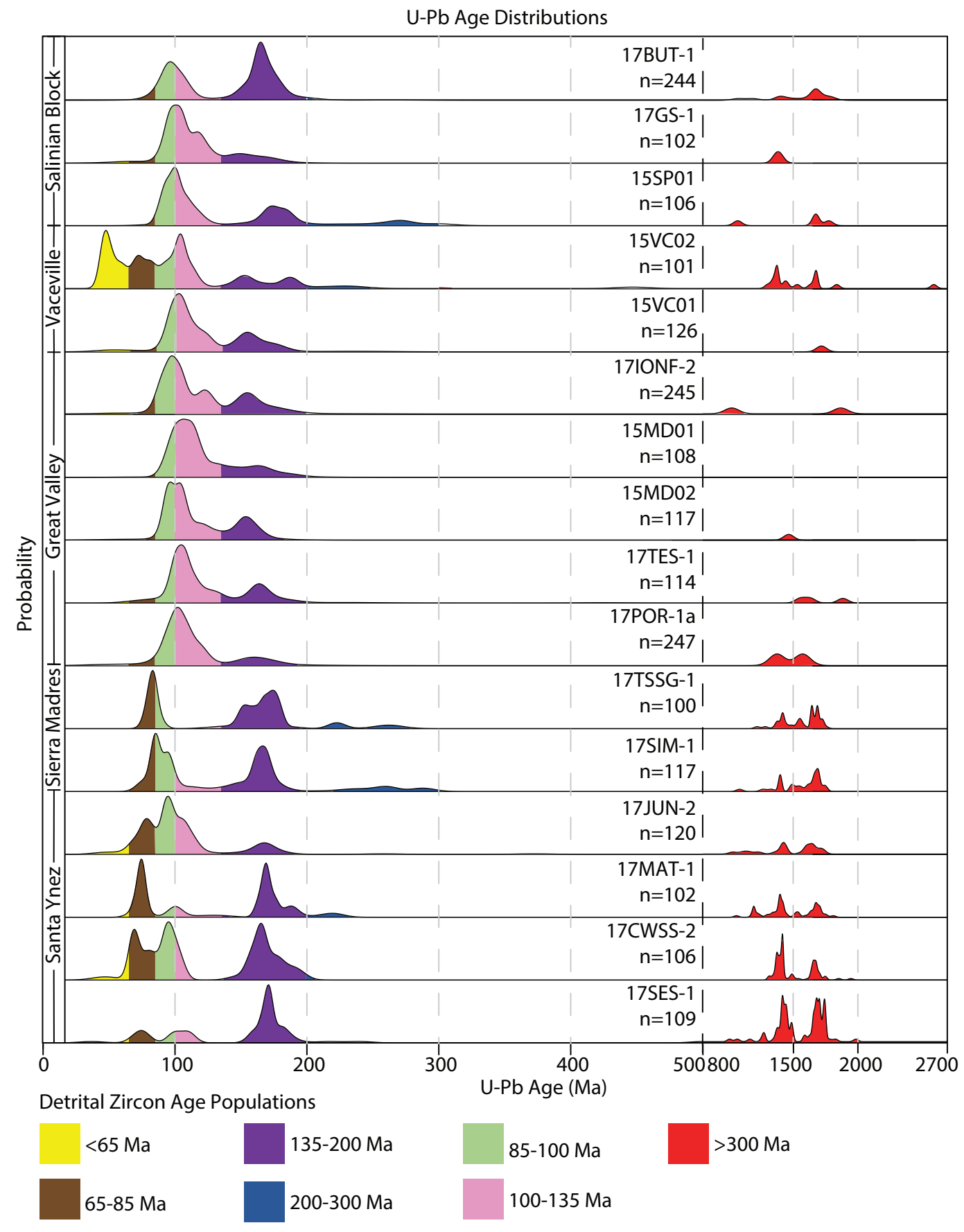


Figure 3. Kernel density estimate (KDE) plots of detrital zircon U-Pb age distributions. Samples are grouped by geography. Colors correspond to age bins from Jacobsen et al. (2011) and Sharman et al. (2015). Note that the proportions of Jurassic (purple) and >300 Ma (red) age populations increase to the south, while samples farther north record larger populations of Cretaceous ages (Sierra Nevada arc ( 135-85 Ma) related ages. 


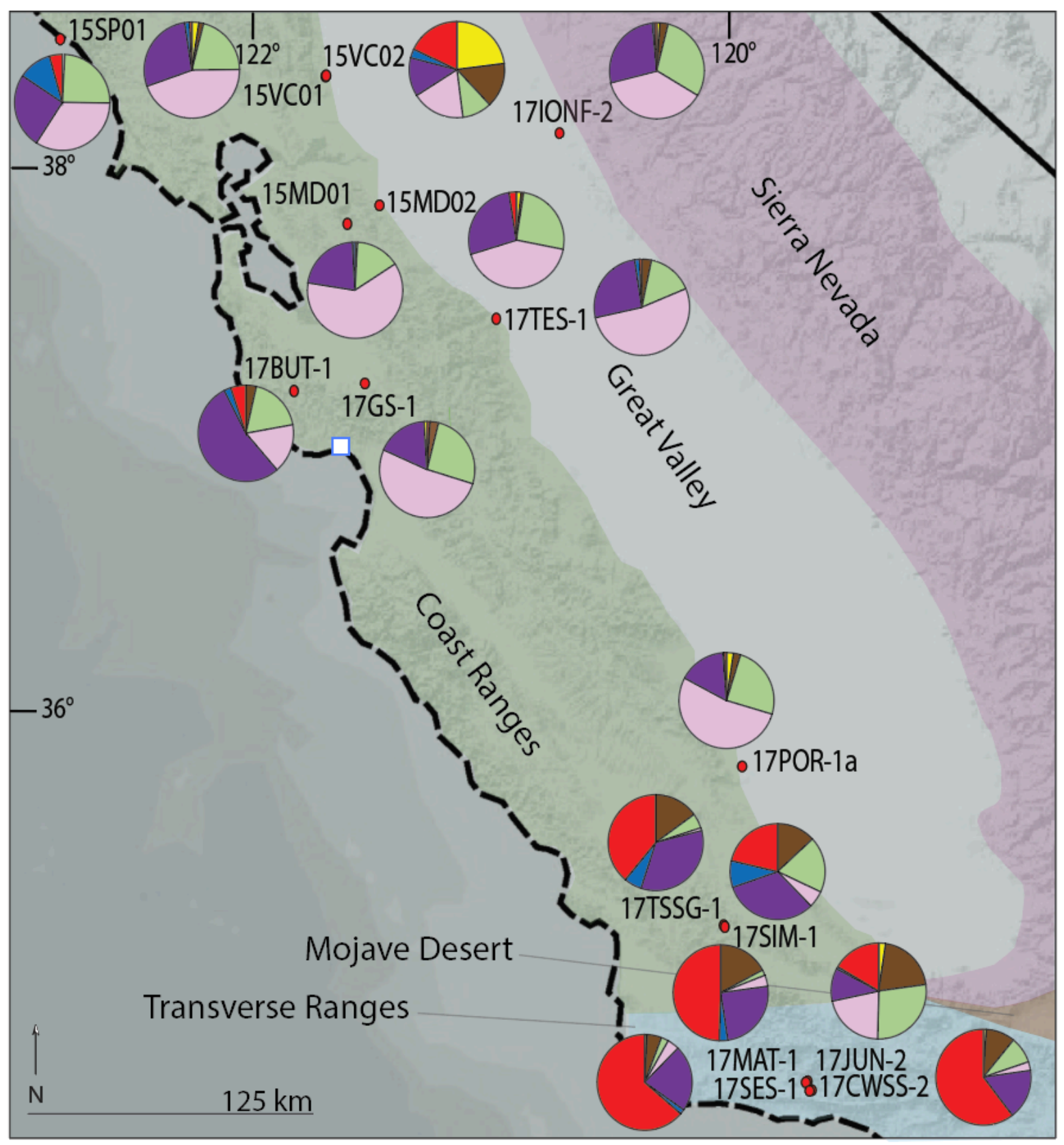

Detrital Zircon Age Populations

\begin{tabular}{|l|l}
\hline $65 \mathrm{Ma}$ & $135-200 \mathrm{Ma}$ \\
\hline $65-85 \mathrm{Ma}$ & $200-300 \mathrm{Ma}$ \\
$85-100 \mathrm{Ma}$ & $>300 \mathrm{Ma}$ \\
$100-135 \mathrm{Ma}$ &
\end{tabular}


Figure 4. Pie charts showing the proportion of different $\mathrm{U}-\mathrm{Pb}$ zircon ages in samples and their locations. Large geographic variability is observed in the proportion of Cretaceous (135-85 Ma) versus Jurassic (135-200 Ma) and >300 Ma age grains in samples. 


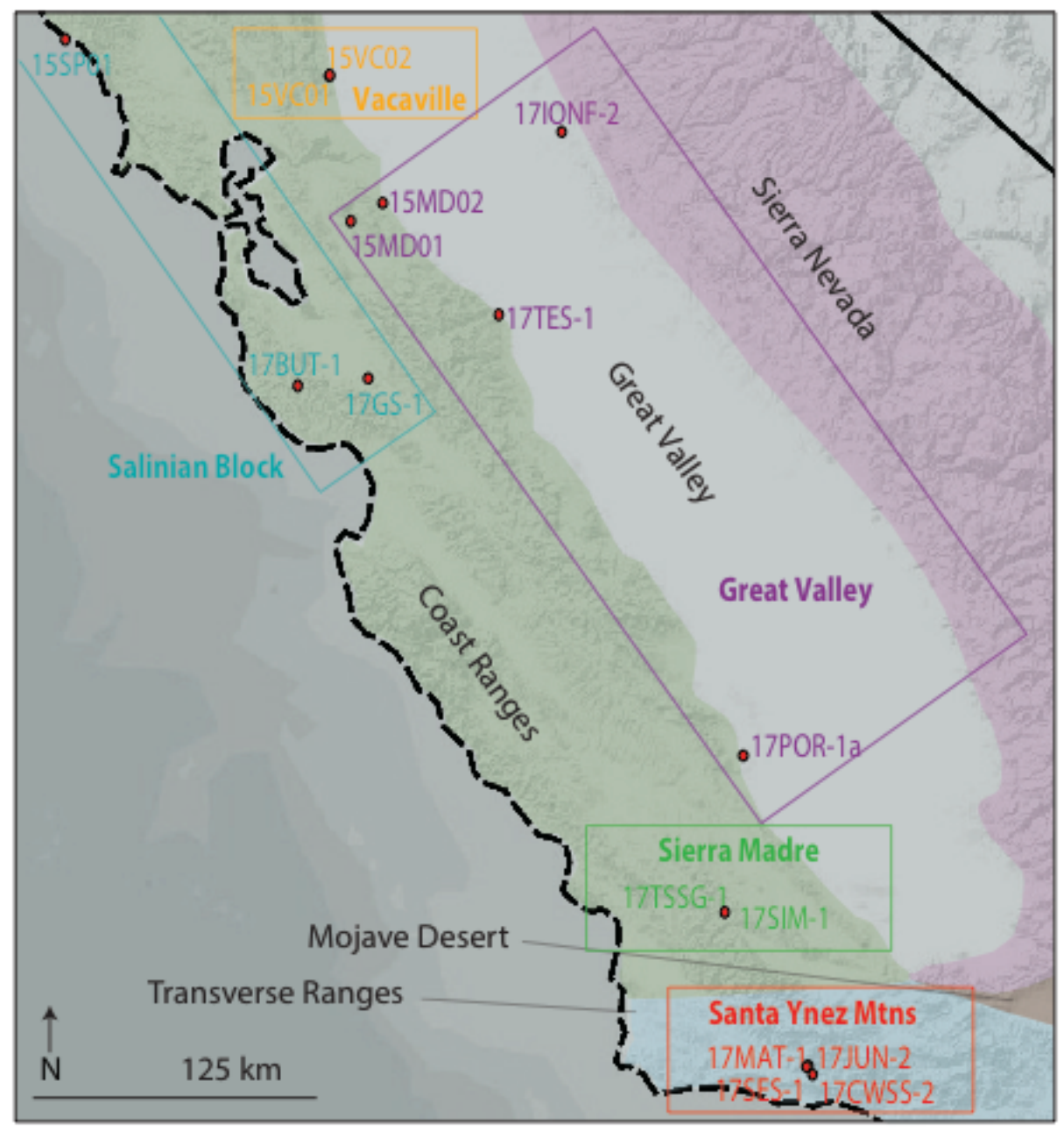

Figure 5. Map showing sample groups based on similarities in $\mathrm{U}-\mathrm{Pb}$ age distributions and geographic position. The Salinian Block, Sierra Madres, and Santa Ynez Mountains samples have been translated along the San Andreas fault and are north of their original depositional location. The Salinian Block and Sierra Madres samples were deposited west of the Mojave, while the Santa Ynez Mountains samples would have been deposited near the northern extent of the Peninsular Ranges batholith. 

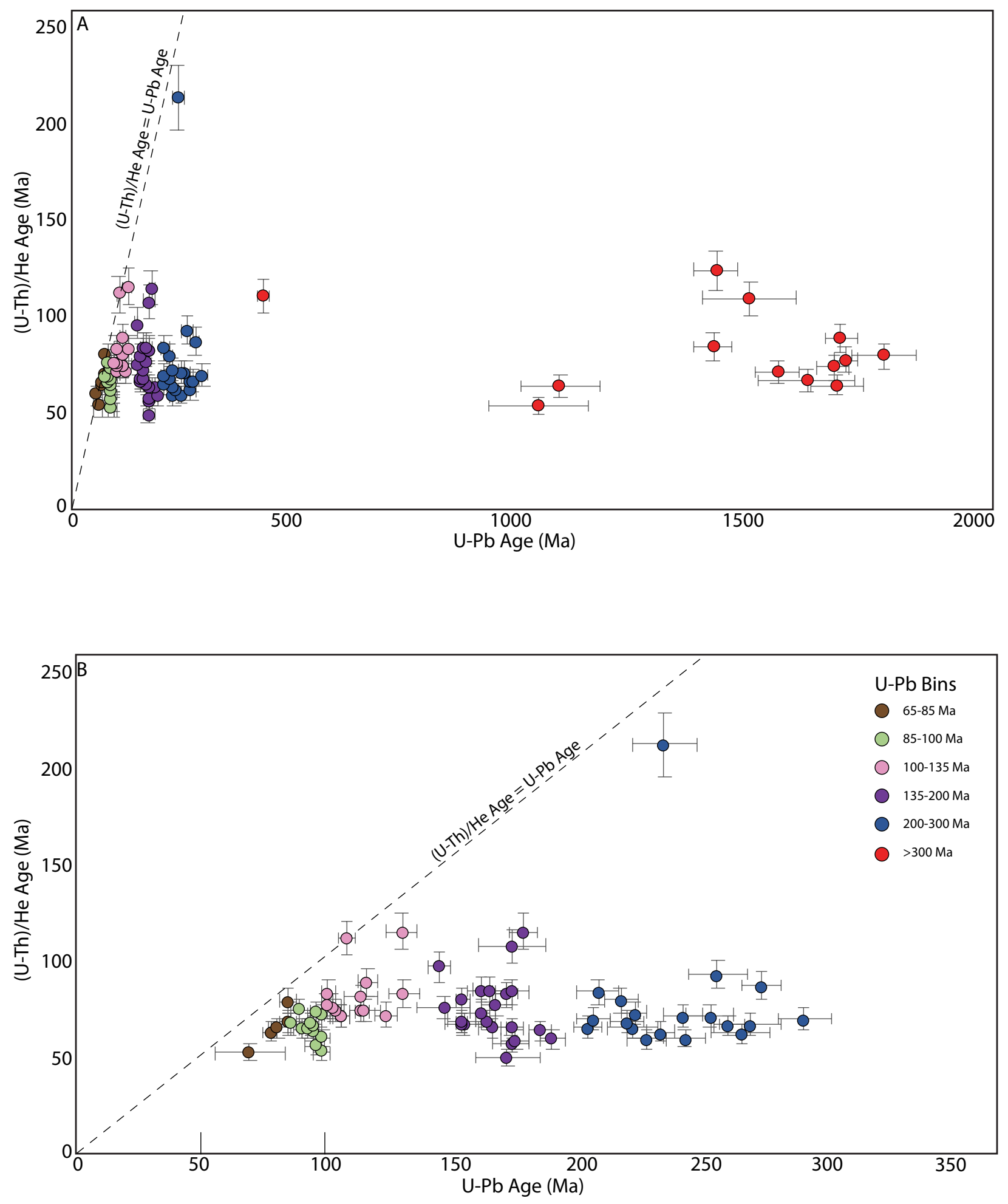

Figure 6. (A) U-Pb vs. He age plot of double-dated zircon grains colored by age bin. (B) Same data rescaled to show grains younger than $350 \mathrm{Ma}$. 

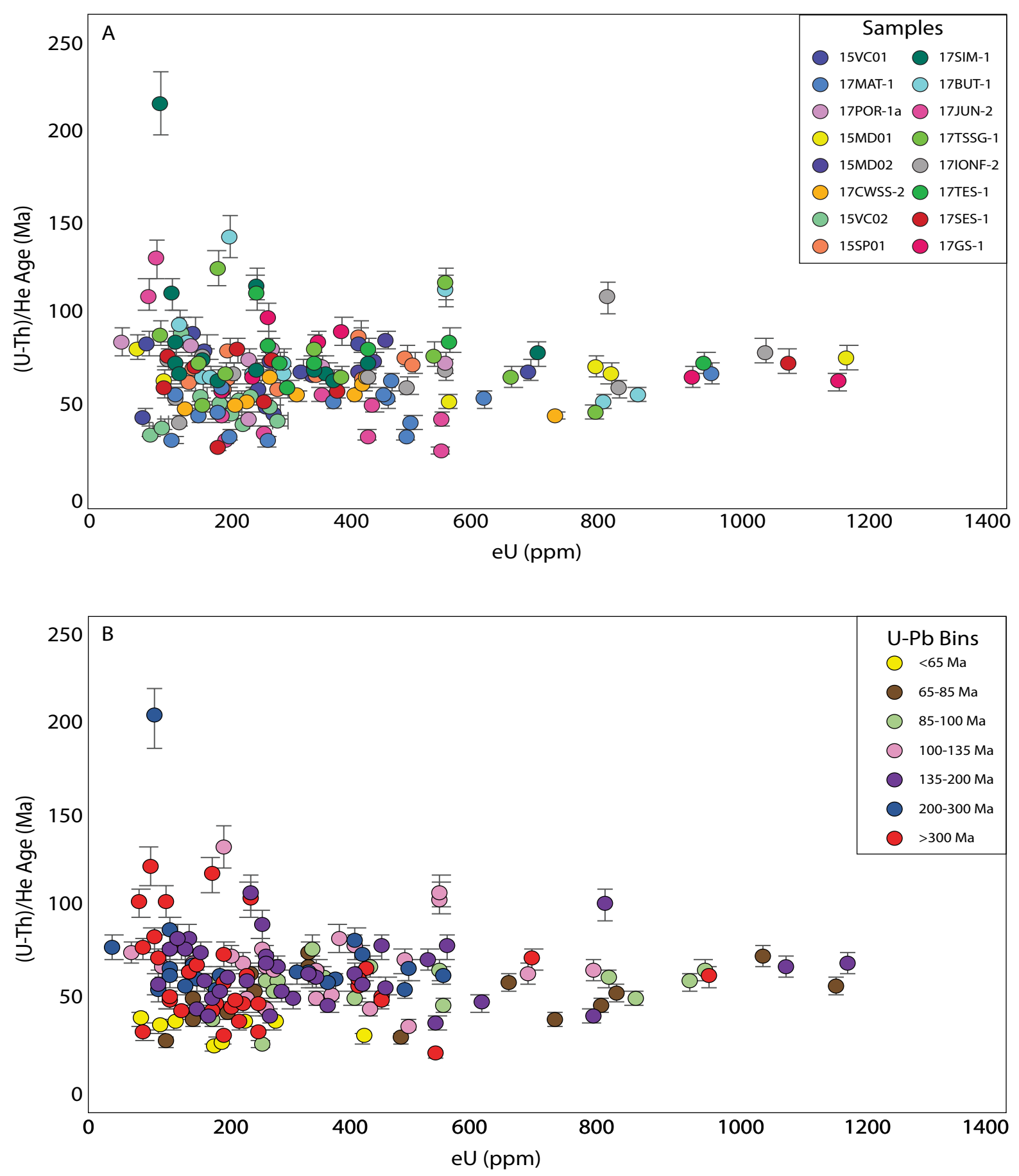

Figure 7. (A) (U-Th)/He dates for each sample plotted against equivalent Uranium (eU) concentrations, a proxy for radiation damage effects on dates. (B) Same data colored by U-Pb age bin from Jacobsen et al., (2011) and Sharman et al. (2015). No correlations were identified. 


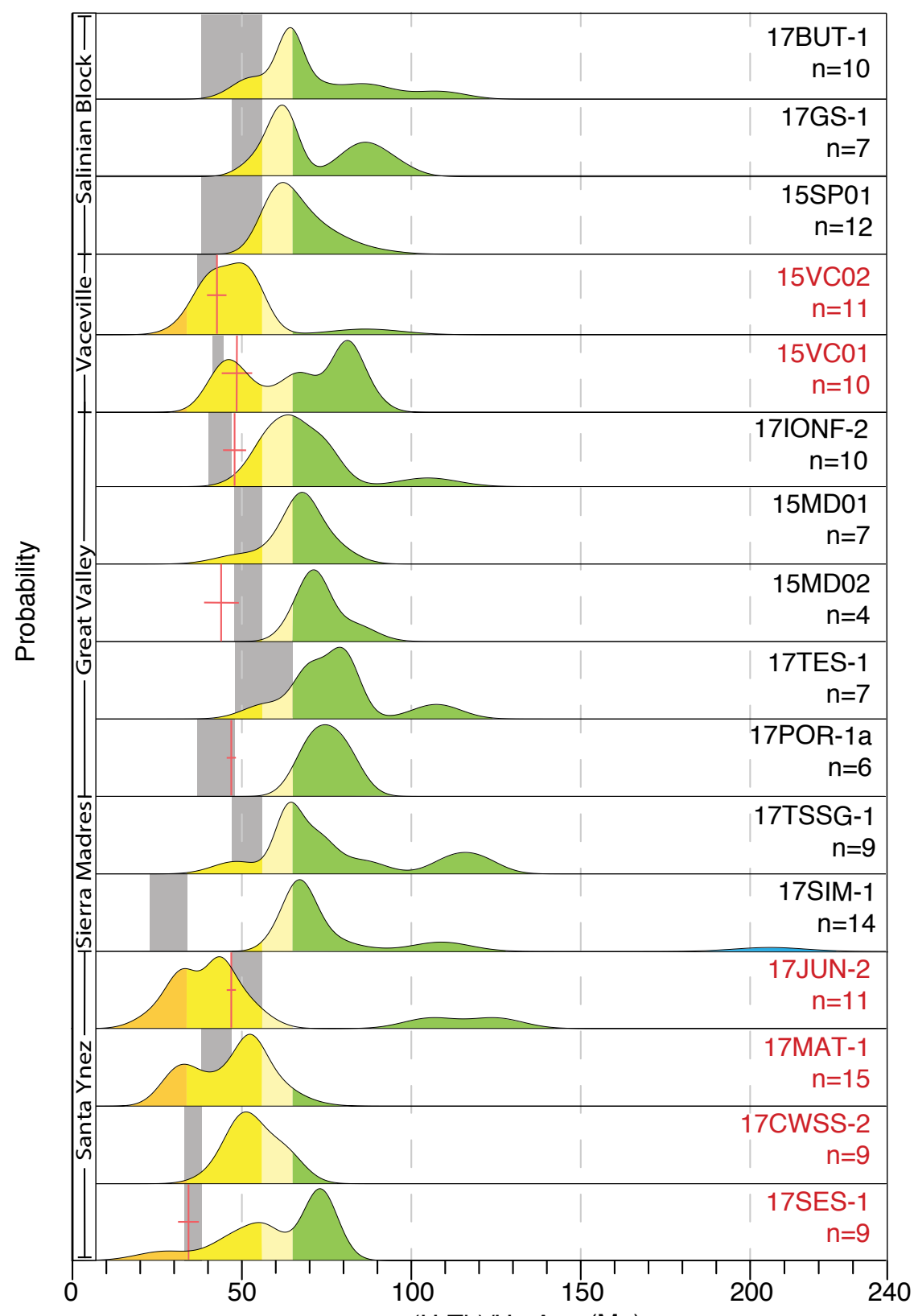

(U-Th)/He Age (Ma)

\section{Oligocene}

Eocene

Paleocene

\section{Cretaceous}

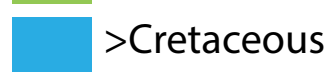

*Red type indicates reset samples

*Red crosses represent the single youngest $\mathrm{U}-\mathrm{Pb}$ age with associated uncertainty representing the MDA

*Grey boxes represent estimated depositional age ranges from literature 
Figure 8. Kernel density estimate (KDE) diagrams of detrital zircon (U-Th)/He date distributions. Samples are grouped by geographic location. Red crosses represent maximum depositional ages obtained in this study, taken from the youngest U-Pb date. Post-depositionally reset samples are indicated by red labels and are not considered further for interpretation. The majority of samples display multiple cooling age peaks which are generally similar between geographic? sample groups. 


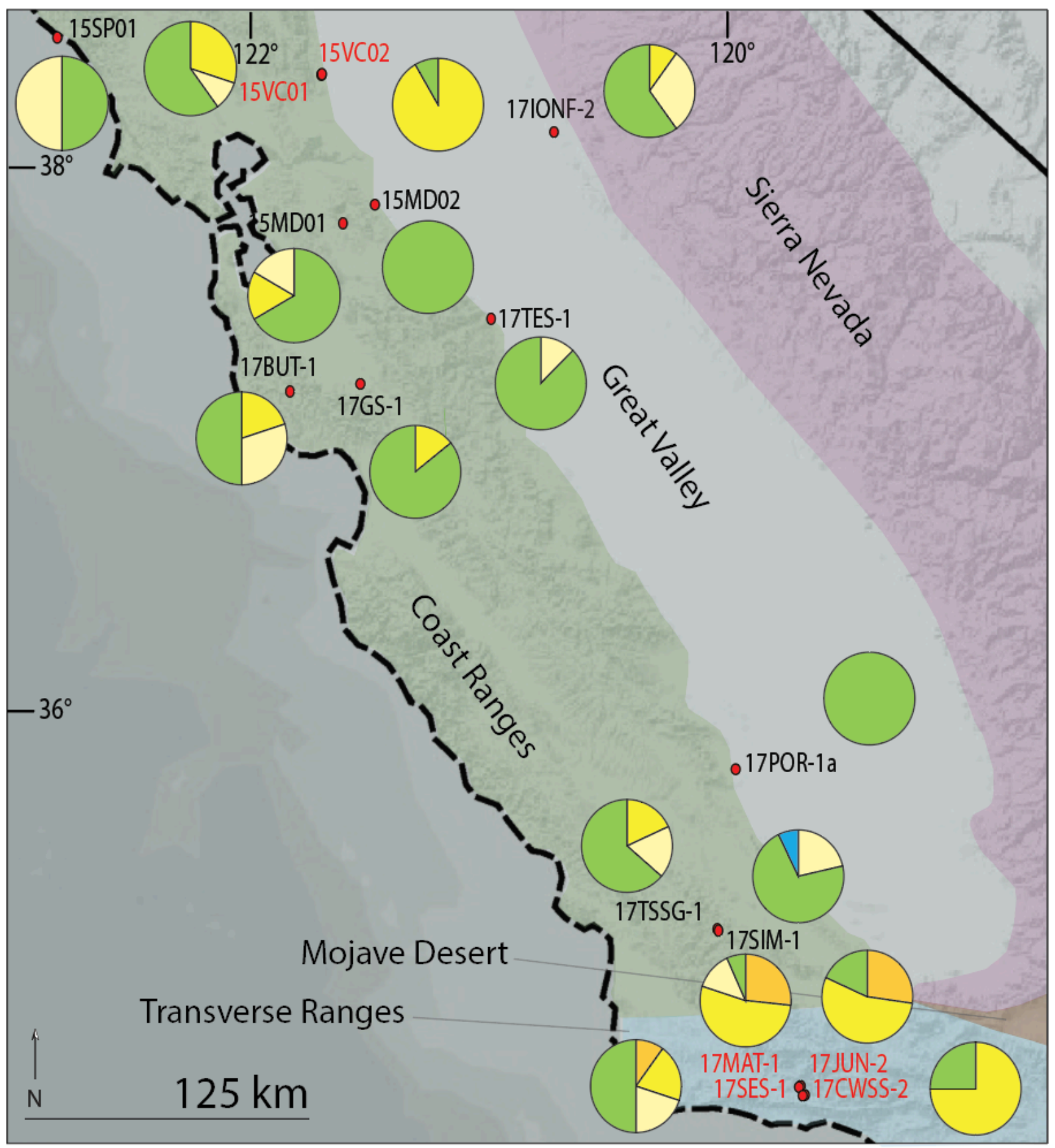

Detrital Zircon Cooling Ages Populations

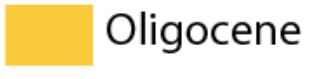

Eocene

Paleocene
Cretaceous

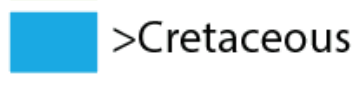

*Red type indicates reset samples 
Figure 9. Pie charts showing the proportion of different (U-Th)/He dates in samples and their locations. Most samples record both Cretaceous (green) and Cenozoic (yellow) cooling dates, but in variable proportions. 


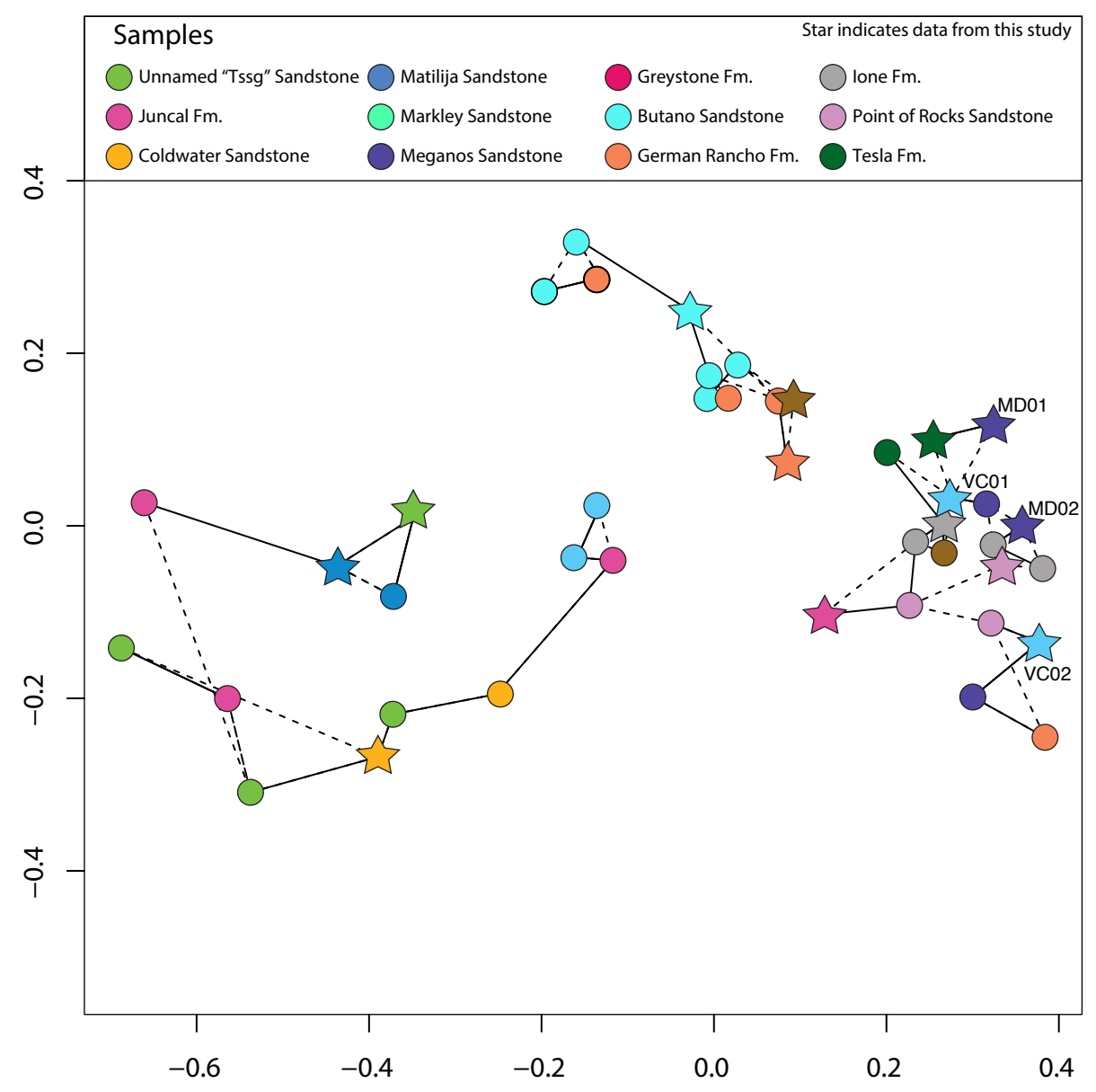

Figure 10. Komogorov-Smirnov-based multidimensional scaling relationships (Vermeesch, 2013) between $\mathrm{U}-\mathrm{Pb}$ zircon data from Eocene samples of this study (stars) and published data (circles) from Jacobsen et al. (2011) and Sharman et al. (2013; 2015). Samples that group together are least dissimilar. Samples with solid tie-lines show their 'primary neighbor' or most similar neighbor. Samples with dashed tie-lines are 'secondary neighbors'. Information on sources and grain counts of published data is provided in Appendix 6. 

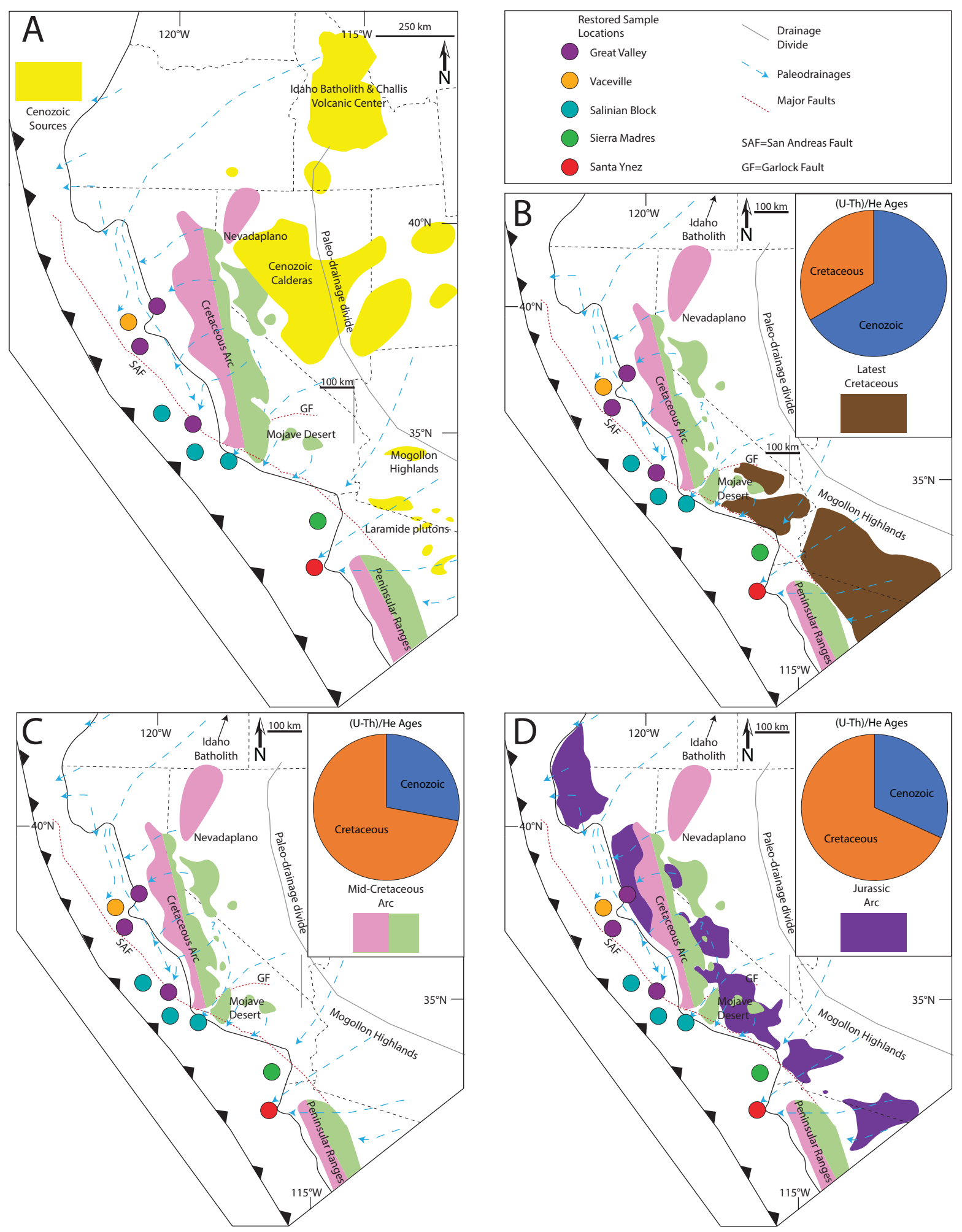

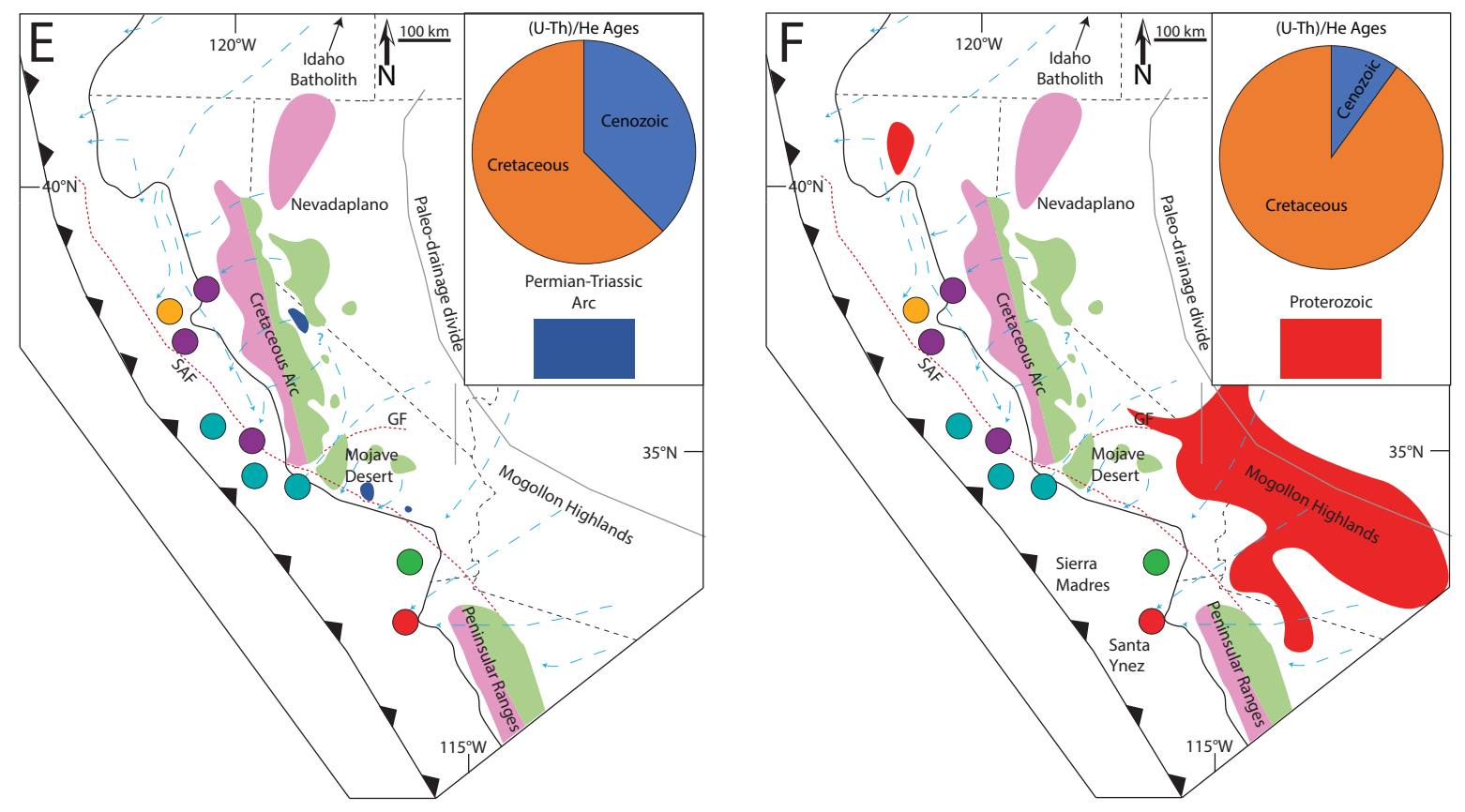

Figure 11. Paleogeographic reconstruction of samples, paleodrainages, and inferred source regions along the California continental margin in the Eocene based on previously published studies (Jacobsen et al., 2011; Cassel et al., 2012b; Sharman et al., 2015). Samples are colored by groups shown in Figure 5. Pie diagrams show the proportion of Cretaceous and Eocene (U$\mathrm{Th}) / \mathrm{He}$ dates for $\mathrm{U}-\mathrm{Pb}$ source region. 
(U-Th)/He Age (Ma)

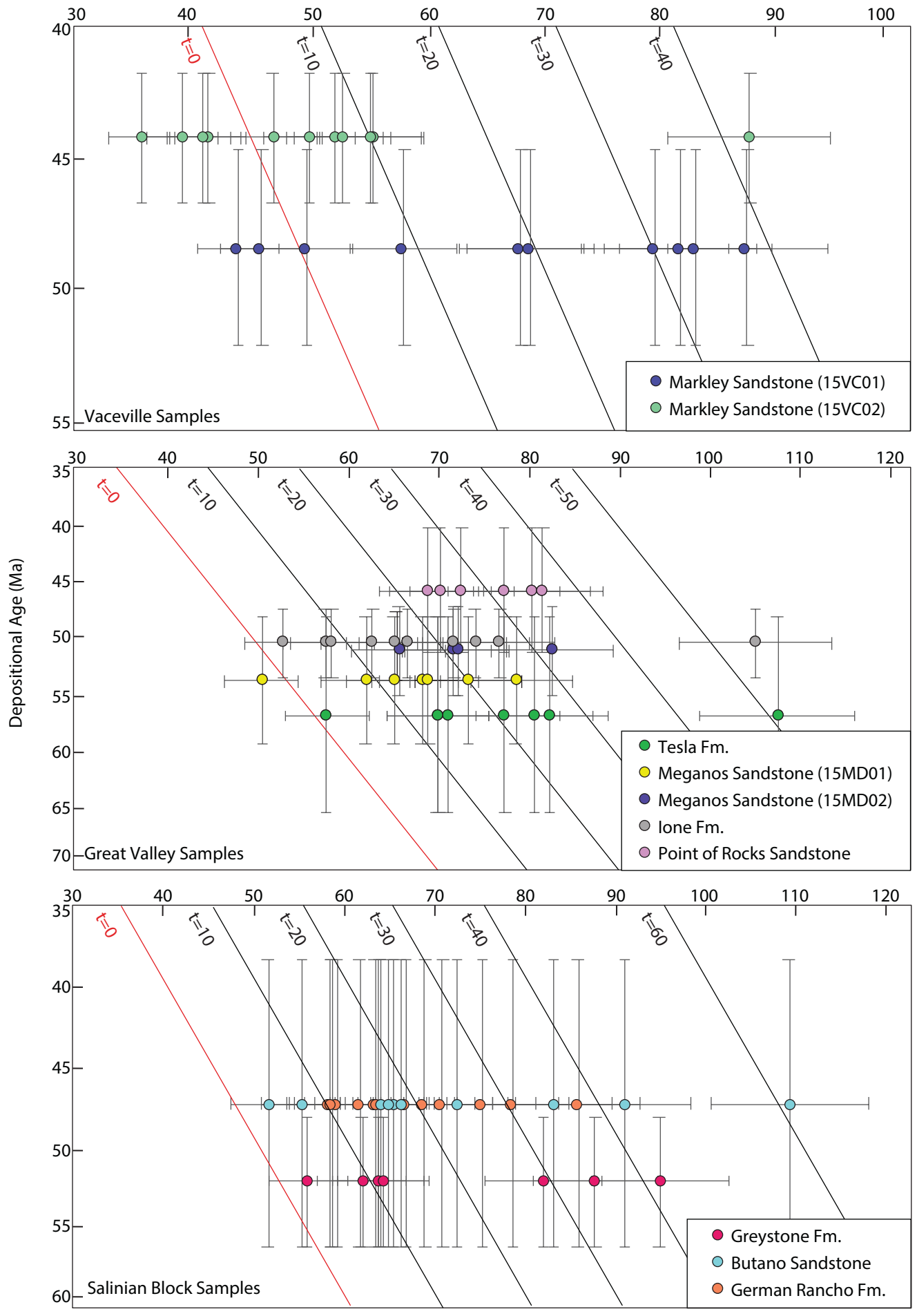




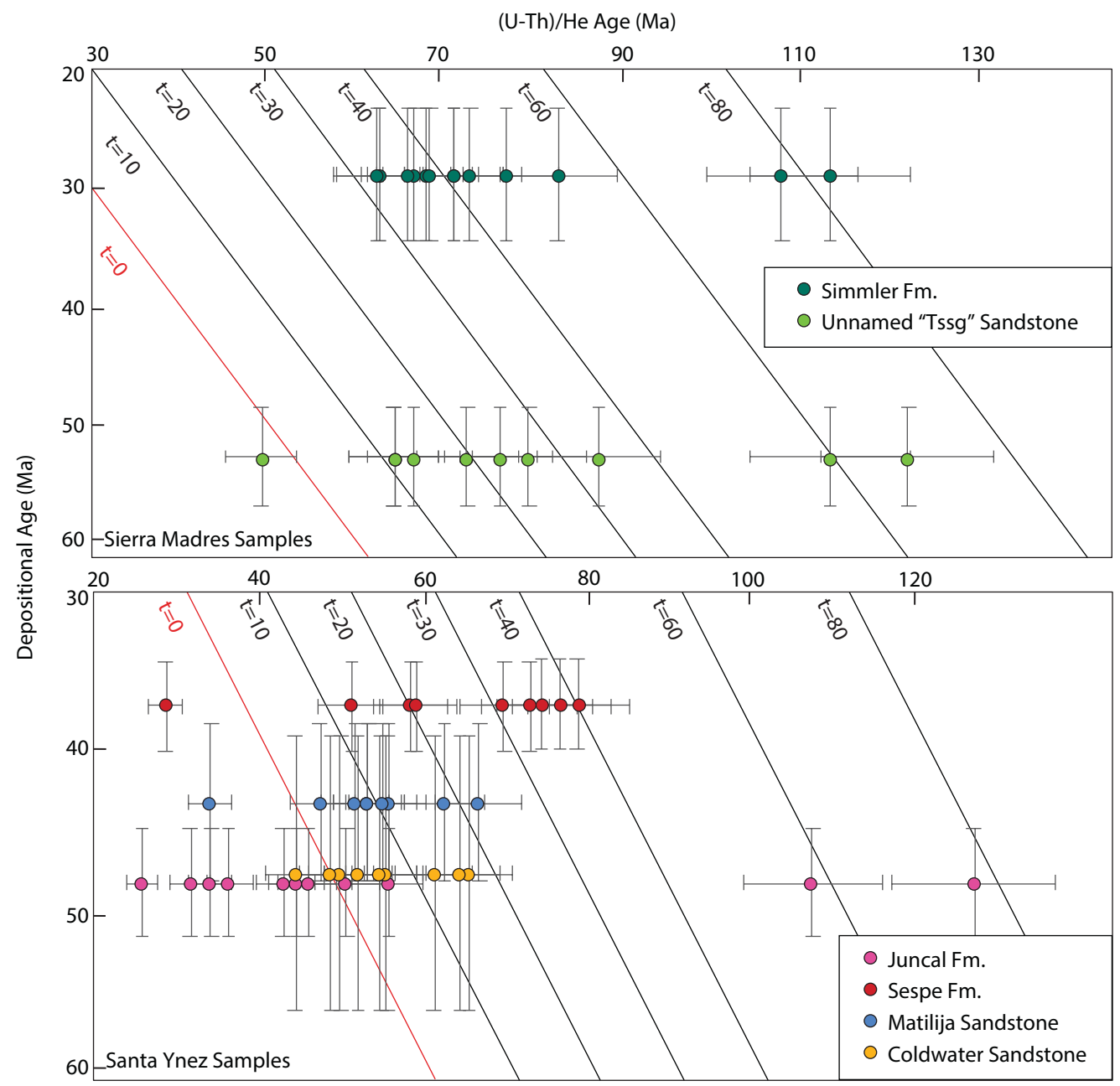

Figure 12. Depositional lag-time plots organized by sample group. Error bars are the uncertainty on depositional age of the unit and the standard (U-Th)/He age error. Depositional age uncertainty is large for most samples with no young grains for maximum depositional age constraints. Solid lines represent lag-times in million years (m.y.). The red ' $t=0$ ' dashed line indicates that depositional age and cooling age are the same. Note that many samples show a spread between long lag-times and very short lag-times ( $\mathrm{t}=0 \mathrm{~m} . \mathrm{y}$.$) .$ 

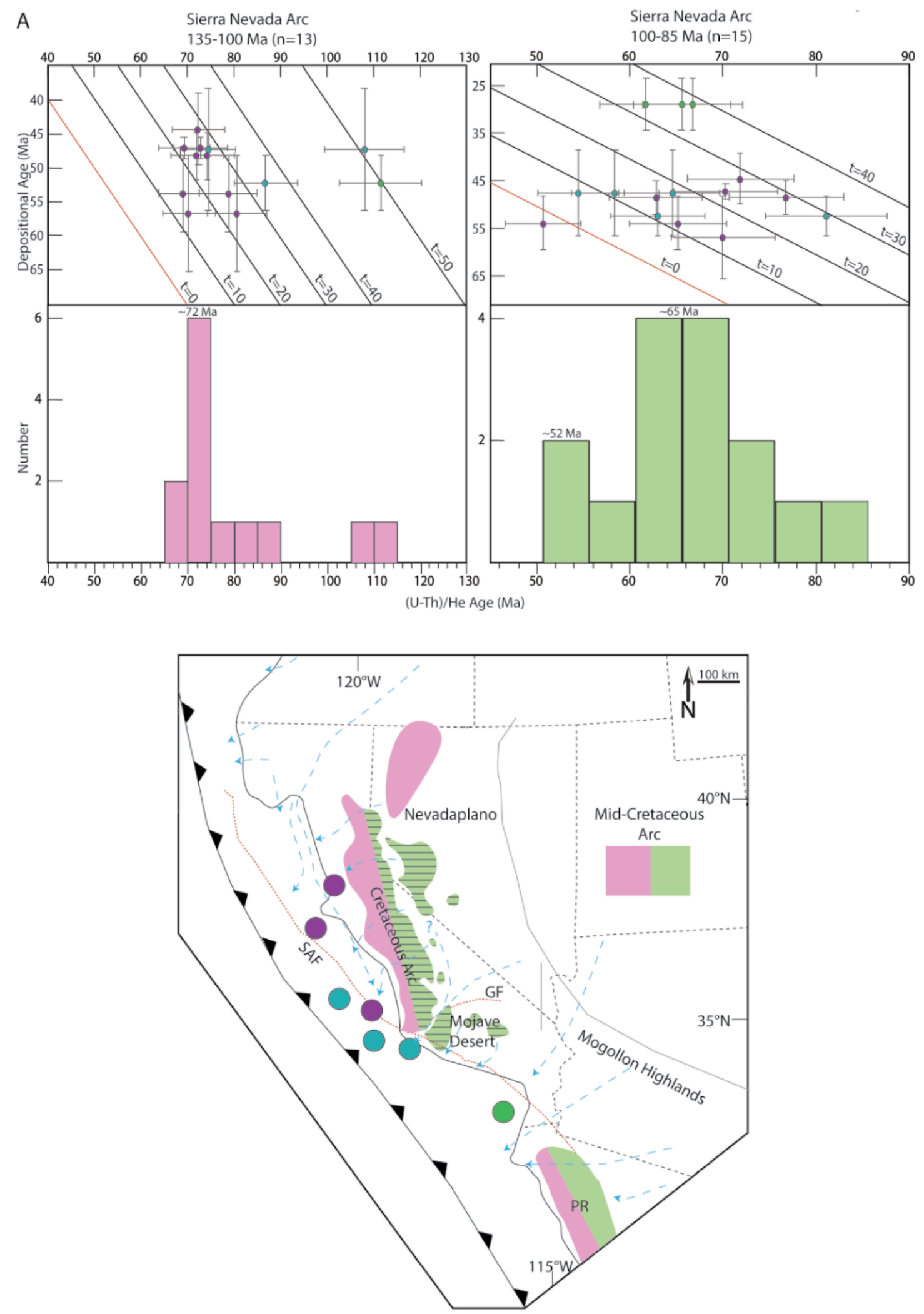

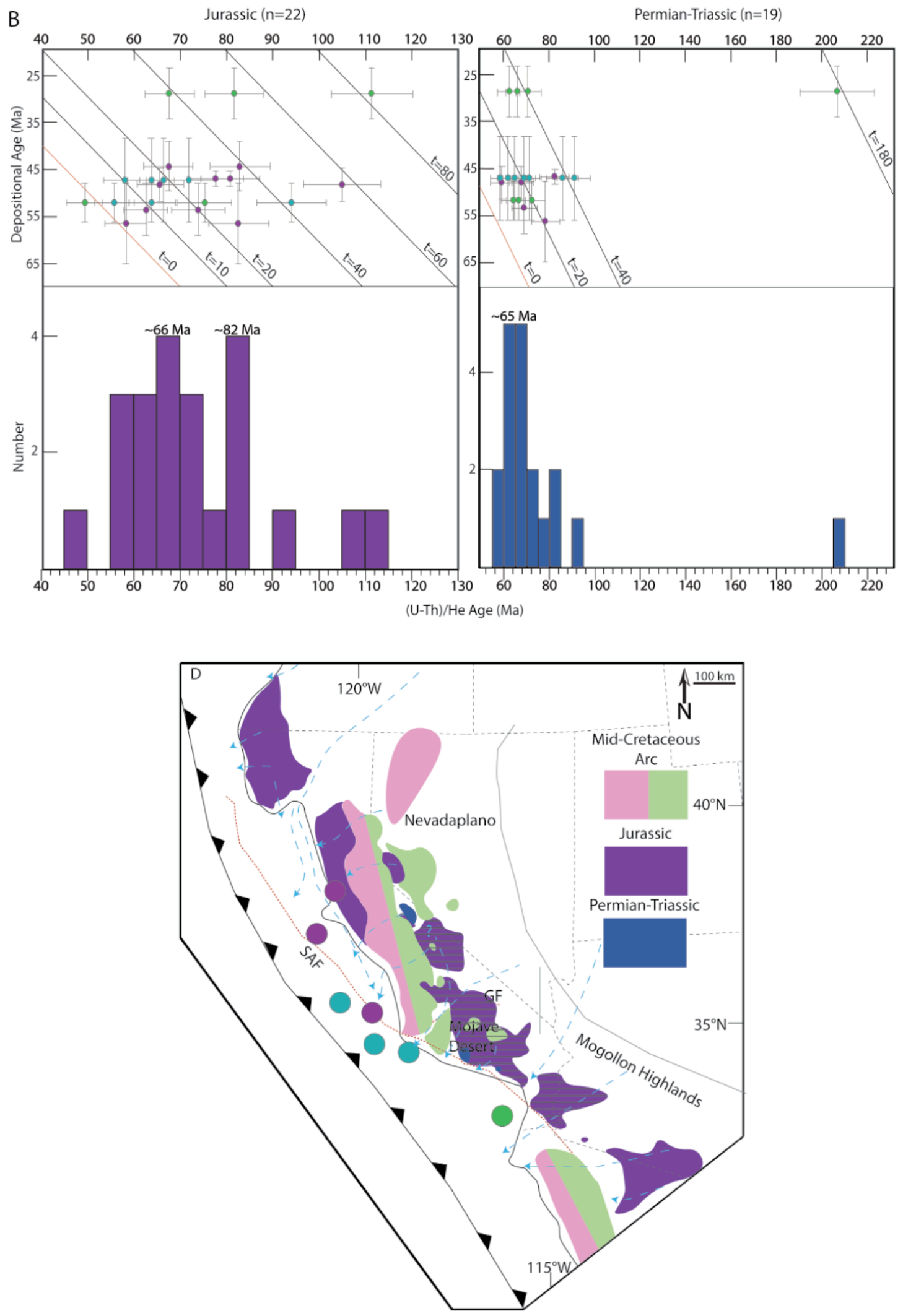

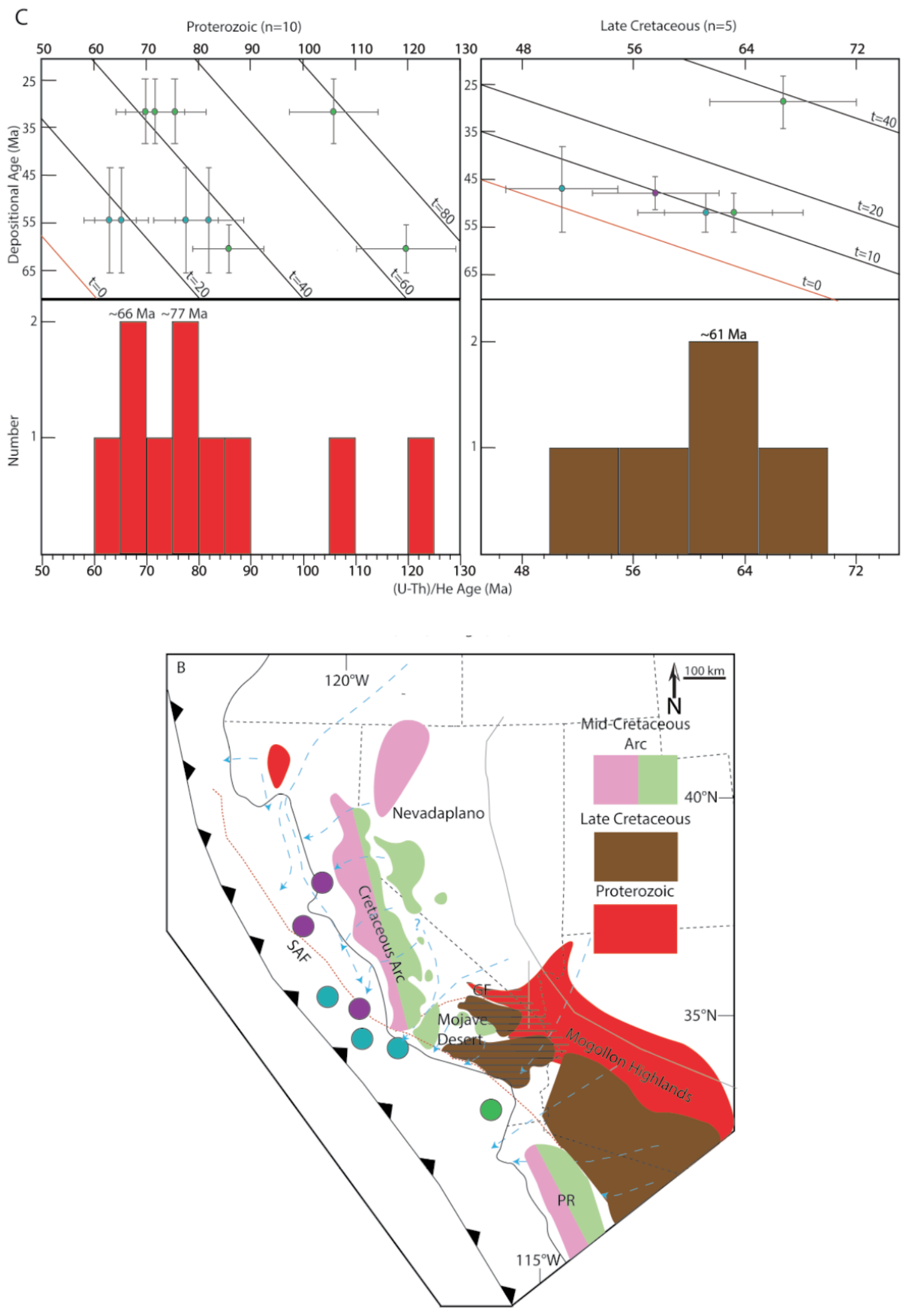


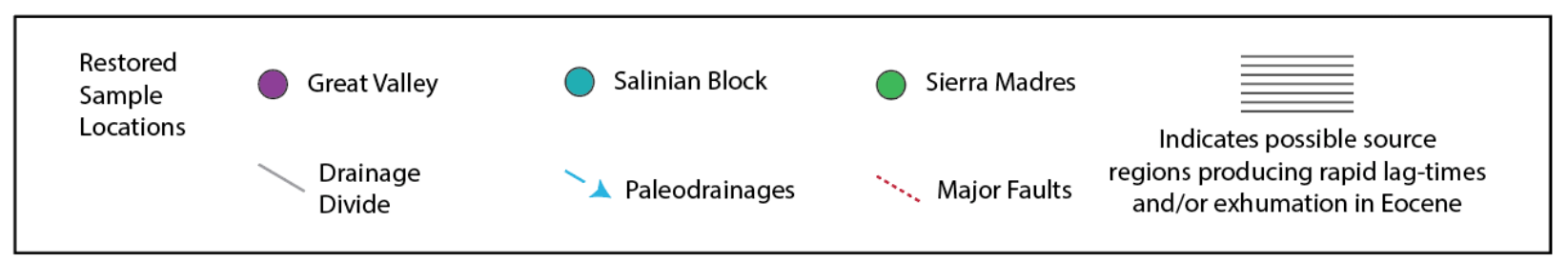

Figure 13: Lag-times colored by sample group with associated cumulative (U-Th)/He histograms showing major cooling peaks both grouped by $\mathrm{U}-\mathrm{Pb}$ age bin. Maps show interpreted source regions for each $\mathrm{U}-\mathrm{Pb}$ age bin. Striped areas on maps indicate area $\mathrm{U}-\mathrm{Pb}$ age source areas that may have produced short lag-times in the Eocene $(<10$ m.y.). For the Proterozoic age rocks, stripes represent areas that may have had $<20$ m.y. between cooling and deposition. Patterns from lag-time and cooling ages indicate that certain source regions were exhuming rapidly in the early Cenozoic, specifically inboard of the Sierra Nevada arc, the Mojave Desert, and the Mogollon Highlands. Abbreviated features: SAF-San Andreas Fault; GF-Garlock Fault; PRPeninsular Ranges. 


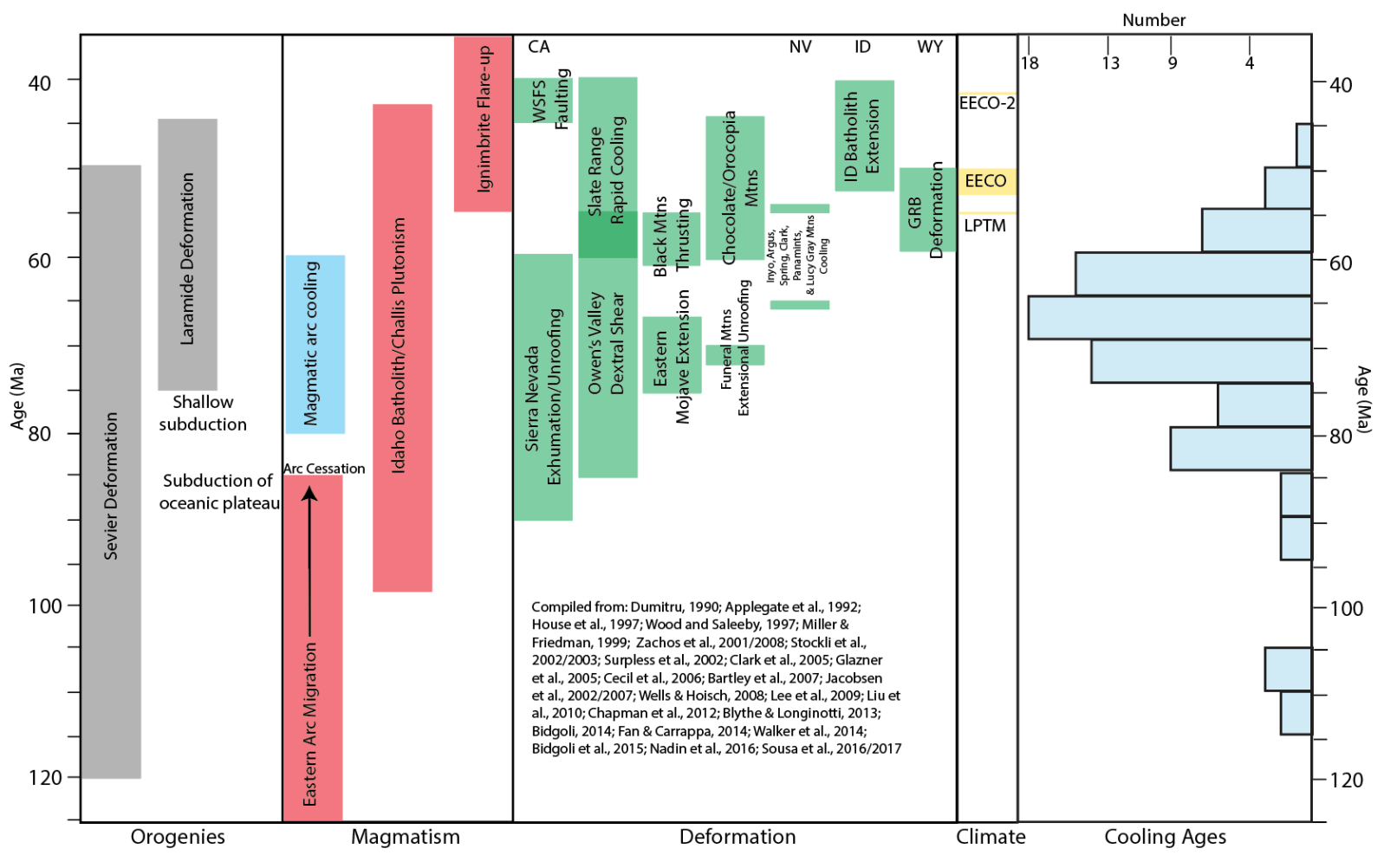

Figure 14. Timing of documented events in the late Cretaceous through Eocene, beginning with (left to right) development of the Sevier and Laramide orogenies, major magmatic episodes, documented deformation/cooling in the western Great Basin, Mojave, and Sierra Nevada, major climate shifts, and a cumulative histogram of all non-reset cooling ages. 


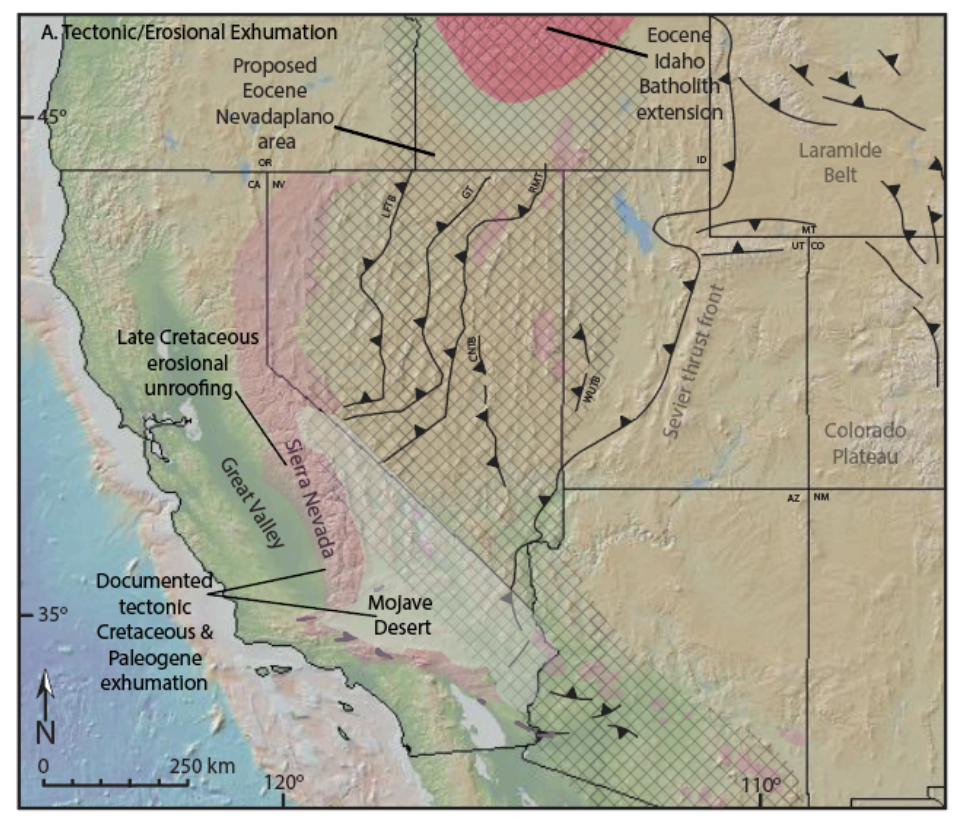

B. Mantle-Driven Exhumation

Cretaceous

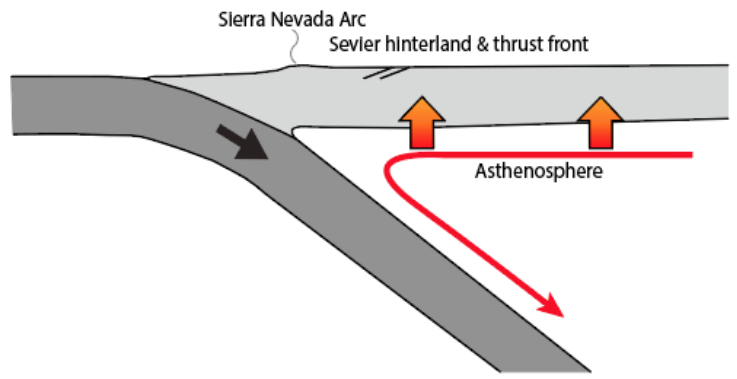

Late Cretaceous-Paleocene

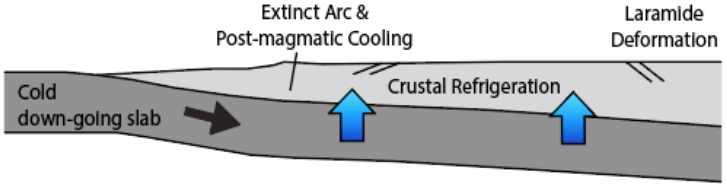

Late Paleocene-Eocene

Slab-rollback and/or break off

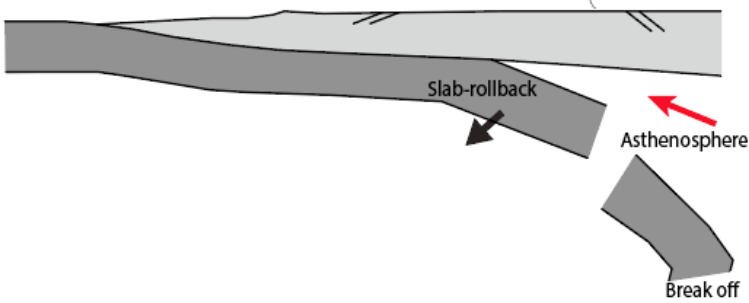

C. Climate-Driven Erosion

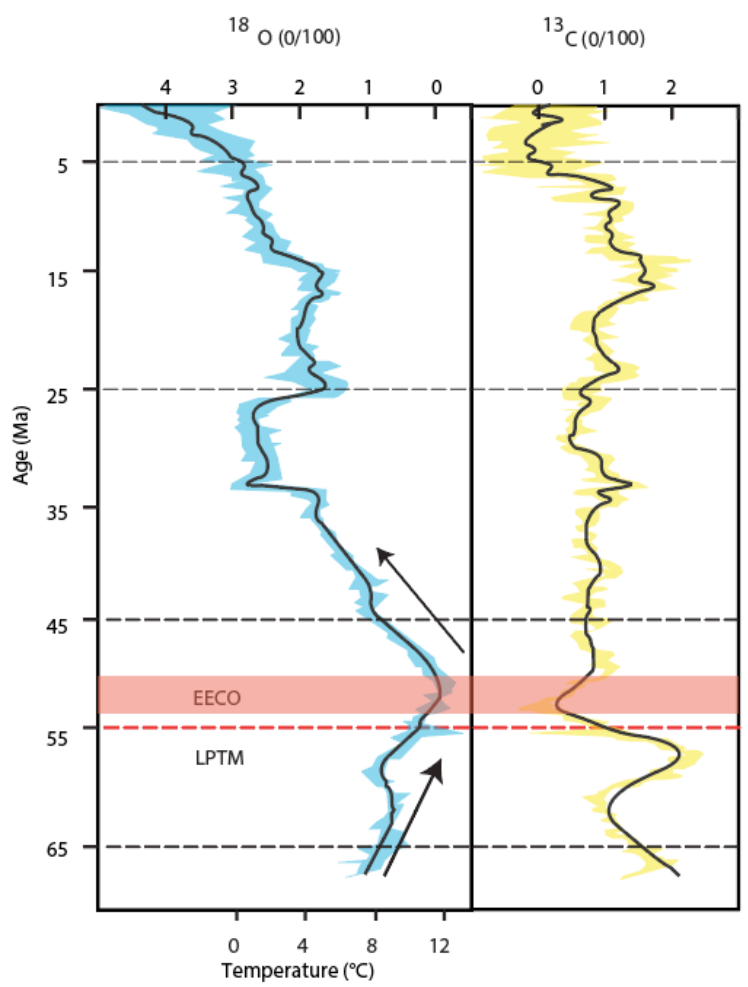


Figure 15. Potential drivers of late Cretaceous to Eocene cooling observed in the (U-Th)/He data. (A) Tectonic and erosional exhumation in the western U.S. associated with Sevier-Laramide orogenies. Cross pattern indicates potential extent of the Nevadaplano at 50 Ma based on Copeland et al. (2017). Red area indicates area of Eocene extension in Idaho Batholith. White area indicates region where two-stage cooling has been previously documented (see Discussion) (B) The generalized cross-section illustrating asthenospheric processes associated during normal subduction followed by expelling of the mantle wedge and refrigeration of the crust during flattening of the subducting slab (Dumitru, 1991). Slab-rollback and/or break-off then occurred in Wyoming by the Eocene. (C) Global climate change during the early Cenozoic, represented by the global oxygen and carbon isotope curves (Zachos et al., 2001; Zachos et al., 2008). Two of the more pronounced events are marked as the Early Eocene Climatic Optimum (EECO) and Late Paleocene Thermal Maximum (LPTM). 


\section{TABLES}

Table 1. Location, name, and age of samples.

\begin{tabular}{|c|c|c|c|c|c|}
\hline Sample & Formation & $\begin{array}{l}\text { Depositional Age } \\
\text { (Ma) }\end{array}$ & Locality & Longitude & Lattitude \\
\hline $15 S P 01$ & $\begin{array}{l}\text { German Rancho } \\
\text { Formation }\end{array}$ & $\begin{array}{c}56-38 \mathrm{Ma} \\
(\mathrm{Mean}=47 \mathrm{Ma})\end{array}$ & Salt Point & -123.332622 & 38.571463 \\
\hline $15 \mathrm{VCO} 2$ & $\begin{array}{c}\text { Markley sandstone } \\
\text { (Possibly Upper Markley } \\
\text { Sandstone) }\end{array}$ & $\begin{array}{c}41.5-36.9 \\
(M e a n=38.75)\end{array}$ & Vacaville & -122.039849 & 38.429267 \\
\hline $15 \mathrm{VCO1}$ & $\begin{array}{c}\text { Markley Sandstone } \\
\text { (Lower Markley } \\
\text { Sandstone) }\end{array}$ & $\begin{array}{c}41.5-36.9 \\
(\text { Mean=38.75) }\end{array}$ & Vacaville & -122.042807 & 38.426885 \\
\hline $17 I O N F-2$ & Ione Formation (Lower) & $\begin{array}{c}47-40.5 \\
(\text { Mean=43.75) }\end{array}$ & $\begin{array}{l}\text { Sierran } \\
\text { Foothills }\end{array}$ & -120.9049943 & 38.20211139 \\
\hline $15 M D 02$ & $\begin{array}{l}\text { Meganos Formation } \\
\text { (Upper "D" Member?) }\end{array}$ & $\begin{array}{c}56-47.8 \\
(\mathrm{Mean}=51.9)\end{array}$ & $\begin{array}{l}\text { Mount } \\
\text { Diablo }\end{array}$ & -121.779395 & 37.921399 \\
\hline $15 M D 01$ & $\begin{array}{l}\text { Meganos Formation } \\
\text { (Lower "A" Member?) }\end{array}$ & $\begin{array}{c}56-47.8 \\
(\mathrm{Mean}=51.9)\end{array}$ & $\begin{array}{l}\text { Mount } \\
\text { Diablo }\end{array}$ & -121.935215 & 37.850267 \\
\hline 17TES-1 & Tesla Formation & $\begin{array}{c}65-47.8 \\
(M e a n=56.4)\end{array}$ & $\begin{array}{l}\text { Del Puerto } \\
\text { Canyon }\end{array}$ & -121.2107313 & 37.47993263 \\
\hline $17 G S-1$ & $\begin{array}{l}\text { Greystone Formation } \\
\text { (Informal) }\end{array}$ & $\begin{array}{c}56-47.8 \\
(\text { Mean=51.9) }\end{array}$ & $\begin{array}{c}\text { Santa } \\
\text { Theresa Hills }\end{array}$ & -121.8525195 & 37.22507035 \\
\hline $17 B U T-1$ & Butano Formation & $\begin{array}{c}56-38 \\
(\text { Mean=47) }\end{array}$ & $\begin{array}{l}\text { Santa Cruz } \\
\text { Mtns }\end{array}$ & -122.1952415 & 37.19731759 \\
\hline $17 P O R-1 a$ & $\begin{array}{l}\text { Point of Rocks } \\
\text { Sandstone }\end{array}$ & $\begin{array}{c}48-37 \\
(\text { Mean=42.5) }\end{array}$ & $\begin{array}{l}\text { Temblor } \\
\text { Ranges }\end{array}$ & -120.0166172 & 35.72718334 \\
\hline 17SIM-1 & $\begin{array}{l}\text { Simmler Formation } \\
\text { (Sandstone) }\end{array}$ & $\begin{array}{c}33.9-23 \\
(\mathrm{Mean}=28.45)\end{array}$ & $\begin{array}{l}\text { Cuyama } \\
\text { Valley }\end{array}$ & -120.0855768 & 35.11088231 \\
\hline 17TSSG-1 & $\begin{array}{l}\text { Sierra Madre Unnamed } \\
\text { Sandstone }\end{array}$ & $\begin{array}{c}56-47.8 \\
(\text { Mean=51.9) }\end{array}$ & $\begin{array}{l}\text { Cuyama } \\
\text { Valley }\end{array}$ & -120.1057363 & 35.10769195 \\
\hline $17 J U N-2$ & Juncal Formation & $\begin{array}{c}56-47.8 \\
(\text { Mean=51.9) }\end{array}$ & $\begin{array}{l}\text { Santa Ynez } \\
\text { Mtns }\end{array}$ & -119.6995586 & 34.49751598 \\
\hline 17MAT-1 & Matilija Sandstone & $\begin{array}{c}47.8-38 \\
(M e a n=42.9)\end{array}$ & $\begin{array}{l}\text { Santa Ynez } \\
\text { Mtns }\end{array}$ & -119.7062963 & 34.49410283 \\
\hline $17 C W S S-2$ & Coldwater Sandstone & $\begin{array}{c}38-33 \\
(\text { Mean=35.5) }\end{array}$ & $\begin{array}{l}\text { Santa Ynez } \\
\text { Mtns }\end{array}$ & -119.6766847 & 34.46407701 \\
\hline 17SES-1 & $\begin{array}{l}\text { Sespe Formation } \\
\text { (Sandstone) }\end{array}$ & $\begin{array}{c}38-33 \\
(\text { Mean=35.5) }\end{array}$ & $\begin{array}{l}\text { Santa Ynez } \\
\text { Mtns }\end{array}$ & -119.6883309 & 34.46072883 \\
\hline
\end{tabular}


Table 2. U-Pb Bin information

\begin{tabular}{|c|c|c|c|}
\hline & Age Bin & $\begin{array}{c}\text { Approximate Age Range } \\
\text { (Ma) }\end{array}$ & Inferred Source Region(s) \\
\hline \multirow[t]{2}{*}{ Cenozoic } & Paleogene & $65-43$ & $\begin{array}{c}\text { Idaho Batholith \& Challis Volcanic } \\
\text { center }\end{array}$ \\
\hline & $\begin{array}{l}\text { Latest Cretaceous- } \\
\text { Paleogene }\end{array}$ & $85-50$ & $\begin{array}{l}\text { Laramide Plutons or Idaho } \\
\text { Batholih }\end{array}$ \\
\hline \multirow[t]{4}{*}{$\begin{array}{l}\text { Cordilleran } \\
\quad \text { Arc }\end{array}$} & Late mid-Cretaceous & $100-85$ & $\begin{array}{c}\text { Eastern Cretaceous Cordilleran } \\
\text { Arc }\end{array}$ \\
\hline & Early mid-Cretaceous & $135-100$ & $\begin{array}{l}\text { Western Cretaceous Cordilleran } \\
\text { Arc }\end{array}$ \\
\hline & Jurassic & $200-135$ & Jurassic Cordilleran Arc \\
\hline & Permian-Triassic & $300-200$ & Early Cordilleran Arc \\
\hline \multirow{3}{*}{$\begin{array}{l}>300 \mathrm{Ma} \\
\quad \text { (Mainly } \\
\text { Proterozoic) }\end{array}$} & Neo-Mesoproterozoic & $910-1310$ & Grenville \\
\hline & Mesoproterozoic & $1310-1580$ & Anorogenic granitic plutons \\
\hline & Late Paleoproterozoic & $1580-1855$ & Yavapai-Mazatzal Province \\
\hline
\end{tabular}


Table 3: Maximum Depositional Age Results

\begin{tabular}{|c|c|c|c|c|c|c|}
\hline Sample & Formation & $\begin{array}{c}\text { Depositional Age } \\
\text { (Ma) }\end{array}$ & $\begin{array}{l}\text { Eocene } \\
\text { Grain } \\
\text { Counts }\end{array}$ & $\begin{array}{c}\text { Youngest } \\
\text { Single } \\
\text { Grain } \\
\text { U-Pb } \\
\text { Age (Ma) } \\
\end{array}$ & $\begin{array}{c}\text { Mean of } \\
\text { Youngest } \\
\text { U-Pb Ages } \\
\text { (Ma) }\end{array}$ & $\begin{array}{c}\text { Overlap } \\
\text { with } \\
\text { estimated } \\
\text { depositional } \\
\text { age? } \\
\end{array}$ \\
\hline $15 S P 01$ & German Rancho Fm. & $\begin{array}{c}56-38 \\
\text { (Mean of 47) }\end{array}$ & - & - & - & - \\
\hline $15 \mathrm{VCO2}$ & $\begin{array}{l}\text { Markley } \\
\text { Sandstone }\end{array}$ & $\begin{array}{c}41.5-36.9 \\
\text { (Mean of 39.2) }\end{array}$ & 19 & $42.8 \pm 2.4$ & $45.2 \pm 1.1$ & yes \\
\hline $15 \mathrm{VCO1}$ & $\begin{array}{l}\text { Markley } \\
\text { Sandstone }\end{array}$ & $\begin{array}{c}41.5-36.9 \\
(\text { Mean=39.2) }\end{array}$ & 3 & $48.5 \pm 4.5$ & $51.5 \pm 1.4$ & no \\
\hline $17 I O N F-2$ & $\begin{array}{l}\text { Ione Fm. } \\
\text { (Lower) }\end{array}$ & $\begin{array}{c}47-40.5 \\
(M e a n=43.75)\end{array}$ & 2 & $47.9 \pm 3.5$ & $49.4 \pm 2.0$ & yes \\
\hline $15 M D 02$ & $\begin{array}{l}\text { Meganos Fm. } \\
\text { (Upper "D" Member?) }\end{array}$ & $\begin{array}{c}56-47.8 \\
(\text { Mean=51.9) }\end{array}$ & 1 & $44.0 \pm 5.3$ & - & yes \\
\hline $15 M D 01$ & $\begin{array}{l}\text { Meganos Fm. } \\
\text { (Lower "A" Member?) }\end{array}$ & $\begin{array}{c}56-47.8 \\
(\text { Mean=51.9) }\end{array}$ & - & - & - & - \\
\hline 17TES-1 & Tesla Fm. & $\begin{array}{c}65-47.8 \\
(\mathrm{Mean}=56.4)\end{array}$ & - & - & - & - \\
\hline $17 G S-1$ & $\begin{array}{l}\text { Greystone Fm } \\
\text { (Informal) }\end{array}$ & $\begin{array}{c}56-47.8 \\
(\text { Mean=51.9) }\end{array}$ & - & - & - & - \\
\hline $17 B U T-1$ & Butano Fm. & $\begin{array}{c}56-38 \\
(\mathrm{Mean}=47)\end{array}$ & - & - & - & - \\
\hline 17POR-1a & $\begin{array}{l}\text { Point of Rocks } \\
\text { Sandstone }\end{array}$ & $\begin{array}{c}48-37 \\
(\mathrm{Mean}=42.5)\end{array}$ & 4 & $46.7 \pm 1.6$ & $47.1 \pm 1.2$ & yes \\
\hline 17SIM-1 & $\begin{array}{l}\text { Simmler Fm. } \\
\text { (Sandstone) }\end{array}$ & $\begin{array}{c}33.9-23 \\
(\mathrm{Mean}=28.45)\end{array}$ & - & - & - & - \\
\hline $17 T S S G-1$ & $\begin{array}{l}\text { Sierra Madre } \\
\text { Unnamed Sandstone }\end{array}$ & $\begin{array}{c}56-47.8 \\
(\text { Mean=51.9) }\end{array}$ & - & - & - & - \\
\hline $17 J U N-2$ & Juncal Fm. & $\begin{array}{c}56-47.8 \\
(\mathrm{Mean}=51.9)\end{array}$ & 2 & $48.1 \pm 3.5$ & $50.5 \pm 2.9$ & yes \\
\hline $17 M A T-1$ & $\begin{array}{l}\text { Matilija } \\
\text { Sandstone }\end{array}$ & $\begin{array}{c}47.8-38 \\
(\mathrm{Mean}=42.9)\end{array}$ & - & - & - & - \\
\hline $17 C W S S-2$ & $\begin{array}{l}\text { Coldwater } \\
\text { Sandstone }\end{array}$ & $\begin{array}{c}38-33 \\
(\mathrm{Mean}=35.5)\end{array}$ & - & - & - & - \\
\hline 17SES-1 & $\begin{array}{l}\text { Sespe Fm. } \\
\text { (Sandstone) }\end{array}$ & $\begin{array}{c}38-33 \\
(M e a n=35.5)\end{array}$ & 1 & $36.9 \pm 3.2$ & - & yes \\
\hline
\end{tabular}

*See Dickinson and Gehrels, 2010 for explanations of maximum depositional ages using U-Pb ages 


\section{APPENDICES}

\section{Appendix 1. Sample Information}

The sandstone formations/units sampled for this study were all between Late Paleocene to Late Eocene in age. Samples were obtained from the Great Valley, Sierran Foothills, Sierra Madre, and the Santa Ynez Mountains. Based on published reconstructions, many of the samples were deposited further south in the Eocene, either on the Salinian/Gualala Block or in the western Transverse Ranges (Jacobsen et al., 2011; Sharman et al., 2015). Here we describe the units in their preset-day north to south configuration and briefly summarize previous provenance work done for the units. Sample locations and age information are listed in Table 1 and are displayed in Figure 1.

\section{Great Valley}

The Great Valley forearc, composed of both the Sacramento and San Joaquin basins, developed in the late Jurassic and continued to subside and accumulate sediment through the Paleogene (Ingersoll, 1979/1983; Bartow, 1991; DeGraaf and Surpless, 2002; DeCelles, 2004). Basin development is associated with accretion of the Klamath Mountains and Sierran Foothills terranes and later with Franciscan subduction (Dickinson and Seely, 1979; DeCelles, 2004). Late Jurassic to Cretaceous sediments, known as the Great Valley Group, rest on the late Jurassic Coast Range ophiolite and increase in thickness towards the west (Ingersoll, 1983; Moxon and Graham, 1987; DeCelles, 2004). In the east, upper Cretaceous sediments lie on Sierran arc basement rocks and are unconformably overlain by Paleogene units (Moxon and Graham, 1987; Moxon, 1988). The Paleogene units, which represents shelf and upper-slope environments, are thickest in the center of the basin and thin to the west and east (Moxon and Graham, 1987; 
Moxon, 1988). Sediments in the Great Valley form an east-dipping homocline due to later uplift of the western side of the forearc basin (DeGraaf and Surpless, 2002).

The Markley Sandstone has a middle Eocene assignment which is based on previous lithologic correlation with the Kreyenhagen Shale and with unpublished subsurface correlations and was deposited in the Markley submarine canyon (Almgren and Filewicz, 1984; Milam, 1985; Dumitru et al., 2013). The Markley Formation includes an upper sandstone, middle Sidney Flat shale, and a lower sandstone and represents continental slope sediments (Milam, 1985). The formation lacks biostratigraphic indicators, and Dumitru et al., (2013) used 44.6-41.5 Ma for the lower sandstone and 41.5-39.5 for the upper sandstone. Samples were taken near Vacaville, California, north of Mt. Diablo where these units have been uplifted and exposed in a series of folds (Sims et al., 1973). Published provenance interpretations suggest this area received detritus from the Idaho Batholith along the Princeton River and Jurassic-Cretaceous Sierra Nevada batholith arc rocks (Sharman et al., 2015).

The Ione Formation is a complex and poorly understood fluvial and marine succession with characteristic detrital and authigenic kaolinite which onlap the western Sierran Foothills (Allen, 1929; Creely and Force, 2007; Cassel et al., 2011). The Ione is thought to be a combination of fluvial, estuarine, and marginal marine facies (Creely and Force, 2007) and is typically interpreted to be correlated with the famous 'auriferous gravels' which are deposited in paleochannels in the northern Sierra Nevada (Allen, 1929; Cassel et al., 2011). We sampled this unit from the lower fluvial portion, overlying the deeply weathered Jurassic bedrock, near Comanche Lake which is in the vicinity of its type locality, Ione, California (Creely and Force, 2007). The Ione Formation is assigned to the middle Eocene, based on molluscan fauna and a correlation with the middle Eocene Domengine Sandstone in the Great Valley subsurface and Coastal Ranges (Creely and Force, 2007). Previous provenance interpretations for the Ione 
Formation infer sources from local rocks in the Sierran Foothills and the Sierra Nevada (Sharman et al., 2015).

Both of the Meganos Sandstone samples were taken from the Mt. Diablo area (one each from the western and eastern flanks). This region, just south of San Francisco Bay, is highly folded and faulted, which primarily occurred in the late Cenozoic, and is cored by the Franciscan complex (Clark, 1921; Schemmann et al., 2008). The Mt. Diablo area is an anticline cut by other major strike-slip faults (Schemmann et al., 2008). The Meganos Formation is assigned a Late Paleocene to early middle Eocene age and was originally deposited in a submarine canyon in the Sacramento basin (Cherven, 1983; Moxon, 1990; Sullivan and Sullivan, 2012). The formation is divided into upper and lower sandstones (Graymer, 1994) where the lower "A" member (unit “Tma" of Graymer et al., 1994) is Late Paleocene to early Eocene and the upper "D" member (unit "Tmd" of Graymer et al., 1994) is Early Eocene in age (Clark, 1921; Nilsen and Clarke, 1975). The age assignments were given by Clark (1921) based on molluscan fauna (Squires, 1988). Previous provenance studies record Cretaceous and Jurassic arc rocks as a major source and the Idaho Batholith to the northeast (Sharman et al., 2015).

The Tesla Formation, sampled in Del Puerto Canyon on the west side of the Great Valley in the Diablo Range, was deposited on a shallow-marine shelf environment near the Stockton Arch (Nilsen and Clarke, 1975; Bartow, 1985). Tesla deposits are considered marginal marine and/or deltaic facies which overlie upper Cretaceous marine sediments (Throckmorton, 1982; Bartow, 1985). The sample in this study was taken on Del Puerto Canyon Road in an area that has been faulted and uplifted in the late Cenozoic (unit "Tt" of Bartow, 1985; unit "Tte1" of Dibblee,1982; Throckmorton, 1982). It is internally folded locally to the south, but the folds die out as the Tesla thins to the north (Bartow, 1985). In the summary given by Throckmorton (1982), the basal Tesla is most likely as old as Paleocene, although Bartow (1985) records sparse 
megafossil fauna and diatom assemblages of Paleocene age. The Tesla reaches as far as the middle Eocene based on marine fauna in the upper portions of the formation (Throckmorton, 1982; Bartow, 1985). The Sierra Nevada batholith and Jurassic arc rocks are the primary sources for the Tesla Formation based on previously published interpretations (Sharman et al., 2015).

The Point of Rocks sandstone of the Kreyenhagen Formation was sampled further to the south in the Temblor Range of the San Joaquin basin (Sharman et al., 2013). Outcrops of the Point of Rocks Sandstone occur east of the San Andreas Fault in a highly faulted and folded section of the western San Joaquin valley, although most of it is interpreted to be buried (Dibblee, 2006a). In the sample locality, the Point of Rocks is exposed as an east plunging syncline which terminates where it is faulted, juxtaposing the Point of Rocks next to the Cretaceous Panoche Formation (Dibblee, 2006a). The Point of Rocks was deposited, similar to the Butano Sandstone, as deep-sea fan and turbidite sequences (Seiders and Cox, 1992). Paleocurrent indicators indicate a north-northwest direction (Seiders and Cox, 1992). Foraminiferal fauna recorded in the Point of Rocks show it is between middle and late Eocene (Nilsen and Clarke, 1975). Published provenance interpretations for the Point of Rocks sandstone includes sources from the Idaho Batholith, which travelled the trench-slope from the north to the San Joaquin Valley, and more local sources from the Jurassic and Cretaceous Sierra Nevada arc (Sharman et al., 2013).

\section{Salinian Block Forearc}

The Salinian, San Francisco, and Gualala Blocks are Proterozoic-Mesozoic basement terranes which have since been translated north along the San Andreas Fault since the Eocene (Ross, 1978; Howell and Vedder, 1978; Mattinson, 1990; Jacobsen et al., 2011). Originally the blocks were situated near the southern Sierra Nevada and Mojave Desert regions but now lie in northern and central California due to translation north along major strike-slip faults (principally 
the San Andreas Fault) in the Cenozoic (Ross, 1978; Howell and Vedder, 1978; Mattinson, 1990; Wentworth et al., 1998; Kidder et al., 2003; Sharman et al., 2015). These blocks acted as depocenters which accumulated sediments continuously from the Cretaceous through Paleogene, and are now incorporated/uplifted into the Coast Ranges in California (Mattinson, 1990; Jacobsen et al., 2011). Herein, we describe the following units as part of the "Salinian Block".

North of San Francisco is the submarine fan deposits of the German Rancho Formation (Anderson, 1998; Elder, 1998; Wentworth et al., 1998). This formation was sampled at Salt Point State Park and crops out in fold limbs of the Gualala block (Wentworth et al., 1998; Anderson, 1998). The Gualala Basin in the Eocene was located further south, prior to translation along the San Andreas Fault, and likely was a deep-sea basin at the time of deposition (Doebbert et al., 2012). Age assignment of the German Rancho Formation was designated by Paleocene-Eocene foraminifera and megafossils, however the youngest foraminifera found in the formation is middle Eocene (Wentworth et al., 1998; Doebbertt et al., 2012). Initial age constraints relied on an overlying basalt K/Ar age ( $23 \mathrm{Ma})$ which indicates the German Rancho must be younger (Turner, 1970; Doebbertt et al., 2012). In the basal conglomerate, Wentworth et al., 1998 reports Paleocene megafossils, although this is only exposed in one area and McDougall (1998) interprets the megafossils to be reworked. The revised age, based on planktic foraminifera, is early to early middle Eocene (McDougall, 1998). The German Rancho Formation based on published provenance studies and northewestern directed paleocurrent data suggest sources from the Mojave block, Sierra Nevada batholith, and the Salinian block (Farmer and Miller, 1983; Elder, 1998; Doebbert et al., 2012).

The Greystone Formation (informal; Short, 1986) sampled in this study came from Loma Chiquita Ridge of the San Francisco Bay block and is exposed west of the San Andreas Fault in 
anticline and syncline ridges (unit Te2 of McLaughlin et al., 2004). The Greystone represents a deep-sea trench-slope basin environment (Beaulieu, 1970). We group the Greystone Formation with the Salinian Block samples due to similarities their original depositiona locations as well as Cenozoic strike-slip displacement history placing them in central or northern California presently. In the sample location, the Greystone is present with an inferred faulted contact with Jurassic Coast Range ophiolitic rocks, although this contact is buried, where the Jurassic Coast Ranges ophiolite rocks are thrusted (McLaughlin et al., 2004). The Greystone Formation does not have any reliable biostratigraphic indicators within it, and previously recorded fossils (summarized in Short, 1986) are interpreted as reworked. Rather, its stratigraphic position above upper Cretaceous Great Valley equivalents, petrographic analysis, and correlation with similar sandstone in the region give it a middle Eocene age (Short, 1986). There is no upper contact for further depositional age constraints as it is covered with Quaternary alluvium (Short, 1986; McLaughlin et al., 2004). The provenance of the Greystone Formation from published studies indicates a local source, almost entirely from the Jurassic and Cretaceous Sierra Nevada batholith (Sharman et al., 2015).

The Butano Sandstone, sampled in the Santa Cruz Mountains south of San Francisco, is a series of turbidite and submarine fan deposits situated on the Salinian Block west of the San Andreas Fault (Seiders and Cox, 1982; Kanter, 1988; Brabb et al., 1997; Sharman et al., 2013). The Butano, based on planktic foraminiferal and nannofossils, is considered early to middle Eocene (Seiders and Cox 1992). We sampled the upper Butano in the vicinity of the Butano Anticline (unit Tbu of Brabb et al., 1997). On the east and west flanks are upper Eocene to Oligocene shales and sandstones, and the Butano was originally deposited in La Honda basin (Nilsen and Clarke, 1975; Kanter, 1988; Brabb et al., 1997). Paleocurrent data suggests the Butano sandstone, when it was positioned further south, records north-northwest-northeast 
transport directions (Critelli and Nilsen, 1996). Published provenance interpretations of the Butano Sandstone indicates sources from the Mojave, Sierra Nevada Batholith and Jurassic arc rocks east of the magmatic arc (Sharman et al., 2013).

\section{Sierra Madre}

In the Cuyama Valley of the Sierra Madre, we sampled two units: an unnamed Eocene sandstone (unit “Tus" from Vedder et al., 1989; unit "Tssg” from Dibblee, 2006b) and the Late Eocene-Oligocene Simmler Formation. The Cuyama Valley lies west of the San Andreas fault and east of the Nacimento Fault zone in a zone of folds and large northwest trending faults (Jennings, 1958; Vedder et al., 1991; Dibblee, 2006b). Although we separate the Sierra Madre from the Salinian Block samples, this area is a remnant of the southernmost Salinian Block (Jacobsen et al., 2011; Sharman et al., 2015). The unnamed Eocene unit is considered a part of a sand-rich turbidite sequence and paleocurrent indicators suggest west-southwest transport directions (Seiders and Cox, 1992). The age assignment for the unnamed Eocene sandstone is early Eocene based on correlations with units in the La Panza Range (Seiders and Cox, 1992). Previous provenance for the unnamed Eocene sandstone indicates sources primarily from the Mojave and Mogollon Highlands (Sharman et al., 2015). The unnamed Eocene sandstone in the sample area is uplifted as a large anticline with the Simmler Formation depositionally overlying it on the west side, and as a faulted contact on the east side of the fold (Dibblee, 2006b). The Simmler Formation, a non-marine succession of sandstone and conglomerate, is dated by the Oligocene age of an interfingering basalt and the erosional contact with the early Eocene units below (Blake, 1982; Balance et al., 1983; Vedder et al., 1991; Wilson et al., 2000). Provenance data and paleocurrent analysis suggests a northward transport direction for the Simmler Formation and local sources based on conglomerate clast compositions (Bartow, 1978; Blake, 1982; Balance et al., 1983). 


\section{Santa Ynez}

The last four samples are representative of an early to late Eocene transect from the Santa Ynez Mountains of the Transverse Ranges, just north of Santa Barbara, California. In the sample area, the units were faulted, folded, and overturned along the major east-west trending Santa Ynez fault (Sylvester and Darrow, 1979; Dibblee, 1986). The section is marine until the late Eocene Sespe Formation where it becomes fluvial and were originally deposited in the Transverse Ranges forearc basin, which has been disrupted by significant Neogene deformation and rotations (Stauffer, 1967; Bottjer and Link, 1984; Dickinson et al., 1995).

At the base of the section, the early to middle Eocene Juncal Formation unconformably overlies Upper Cretaceous marine strata, representing the resurgence of sedimentation after a prolonged erosional hiatus (Nilsen and Clarke, 1975; Thompson, 1988). The Juncal Formation is the remnants of a submarine fan and consists of thick sandstones and sections of shale and thin turbidite facies (Stauffer, 1967; Vedder, 1972; Thompson, 1988). The age of the Juncal Formation is based on nannofossil, benthic and planktonic formainifera indicates early to middle Eocene (Nilsen and Clarke, 1975; Thompson, 1988). Also, a regional bed of molluscan fauna near the base of the formation indicates an early Eocene depositional age (Thompson, 1988). Paleocurrent data from the Juncal Formation shifts from southwest at the base to west-southsoutheast near the top of the formation (Nilsen and Clarke, 1975).

Overlying the Juncal Formation is a progradational-retrogradation-progradational sequence (Thompson, 1988). The Matilija Sandstone, with depositional contacts above and below, is a massive section of sandstone with minimal mud and represents shallow marine and mid-fan deposits (Stauffer, 1967; Vedder, 1972; Nilsen and Clarke, 1975; Thompson, 1988). Age assignments, based on molluscan fauna, megafossils, and microfossils summarized by Vedder (1972), place the Matilija in the middle to late Eocene. Paleocurrent data for the Matilija 
indicates transport to the west and south (Nilsen and Clarke, 1975). A shale unit (Cozy Dell Shale) separates the Matilija Sandstone from the Coldwater Sandstone. The Coldwater Sandstone is the uppermost marine unit in the Eocene and interfingers with the Cozy Dell Shale (Stauffer, 1967; Jiao and Fritsche, 1994). The Coldwater Sandstone is described as a fossiliferous marine sandstone of late Eocene age based on benthic foraminifera and molluscan fauna (Staufer, 1967; Vedder, 1972; Nilsen and Clarke, 1975). Considered representative of shelf and marginal marine environments, it is transitional into the overlying Sespe Formation, which marks the end of the marine succession (Jiao and Fritsche, 1994; Dickinson, 1995). Generally, the provenance of the marine section from the Santa Ynez indicates primary sources from the Mojave and Mogollon Highlands, with little input from the Sierra Nevada arc (Sharman et al., 2015).

The Sespe Formation in the sample locality likely is transitional from a marine to terrestrial unit, and therefore is likely late Eocene in the sample location (Stauffer, 1967). Howard (1995) summarizes biostratigraphic data for the age of the Sespe Formation, with terrestrial vertebrates documented in the middle of the formation, Oligocene fauna upsection, and an ash bed is present in parts which has a K/Ar age of $27.8 \pm 0.28 \mathrm{Ma}$. The majority of the Sespe Formation is terrestrial conglomerates, although the base of the formation as mapped by Dibblee (1986), includes what is likely is the transitional portion between the Coldwater Sandstone and the basal Sespe Formation. The sample section for this study was a small section of thinly bedded pink sandstone (unit "Tspss" of Dibblee, 1986). Paleocurrent data for the Sespe Formation suggest west and south transport directions (Howard, 1995). Previous provenance work, using conglomerate clast analysis, suggests that the Sespe Formation by the Oligocene was tapping the Yavapai-Mazatzal terrane of Arizona, the Mojave, and Sonora, Mexico regions (Howard, 2000). 
Appendix 2. Analytical Parameters

\begin{tabular}{|c|c|}
\hline Laboratory \& Sample Preparation & \\
\hline Laboratory name & $\begin{array}{l}\text { The University of Kansas, Isotope Geochemistry } \\
\text { Laboratories }\end{array}$ \\
\hline Sample type/mineral & Zircon \\
\hline Sample preparation & Standard mineral separation, tape mounts \\
\hline Laser ablation system & \\
\hline Make, Model \& type & $\begin{array}{l}\text { Arf excimer } 193 \mathrm{~nm} \text {, Photon Machines Analyte G2, } \\
\text { ATLEX300 }\end{array}$ \\
\hline Ablation cell \& volume & Helex 2, two-volume cell \\
\hline Laser wavelength (nm) & 193 \\
\hline Pulse width (ns) & 5 \\
\hline Fluence $\left({\left.\mathrm{J} . \mathrm{cm}^{-2}\right)}^{2}\right.$ & 2 \\
\hline Repetition rate $(\mathrm{Hz})$ & 10 \\
\hline Spot size (um) & 20 \\
\hline Carrier gas & $\mathrm{He}, 1.01 \mathrm{l} / \mathrm{min}, \mathrm{Ar}, 1.1 \mathrm{l} / \mathrm{min}$ \\
\hline Ablation duration (secs) & 25 \\
\hline ICP-MS Instrument & \\
\hline Make, Model \& type & Thermo Element2 magnetic sector field ICP-MS \\
\hline RF power $(\mathrm{W})$ & $1115-1160$ \\
\hline Make-up gas flow (1/min) & Ar, $1.11 / \mathrm{min}$ \\
\hline sampling depth (z position of torch) & $-3.5--4.0$ \\
\hline Detection system & single detector, counting \& analog \\
\hline Masses measured & $\mathrm{Pb} 206, \mathrm{~Pb} 207, \mathrm{~Pb} 208, \mathrm{Th} 232, \mathrm{U} 238$ \\
\hline Integration time per peak (ms) & $1-5 \mathrm{~ms}$ \\
\hline Total method time & 44 \\
\hline Gas blank (s) & 21 \\
\hline IC Dead time (ns) & 2 \\
\hline $\mathrm{UO}+/ \mathrm{U}+(\%)$ & $0.1-0.25$ \\
\hline $238+/ 232 \mathrm{Th}+$ & $0.5-0.6$ \\
\hline Data Processing & \\
\hline Reference Material info & GJ1* (Jackson et al. 2004) \\
\hline $238 \mathrm{U} / 238 \mathrm{U}$ & 137.88 \\
\hline Data processing package used / Correction for LIEF & ET_Redux \\
\hline Common- $\mathrm{Pb}$ correction, composition and uncertainty & $\mathrm{N} / \overline{\mathrm{A}}$ \\
\hline Uncertainty level \& propagation & Age uncertainties are reported as $\pm 2 \sigma$ \\
\hline Reproducibility (\%) & See Appendix $2^{*}$ \\
\hline Quality control / Validation & $\begin{array}{l}\text { Plesovice (Slama et al. 2008, Kosler et al. 2013) } \\
\text { Fish Canyon Tuff (e.g. Wotzlaw et al. 2013) }\end{array}$ \\
\hline
\end{tabular}


Appendix 3. U-Pb Secondary Reference Material Values for the Analytical Sessions

\begin{tabular}{|c|c|c|}
\hline \multicolumn{1}{|c|}{ Sample Run } & Plešovice & Fish Canyon Tuff \\
\hline 17MAT-1/17GS-1 & $342.2 \pm 1.6(\mathrm{MSWD}=1.6)$ & $28.82 \pm 0.45(\mathrm{MSWD}=1.9)$ \\
\hline 15VC01/15VC02 & $338.3 \pm 3.1 \mathrm{Ma}(\mathrm{MSWD}=1.3)$ & $28.79 \pm 0.49 \mathrm{Ma}(\mathrm{MSWD}=1.1)$ \\
\hline 17TES-1/17SES-1 & $343.8 \pm 3.1(\mathrm{MSWD}=0.98)$ & $29.12 \pm 0.49(\mathrm{MSWD}=1.8)$ \\
\hline 17POR-1a & $341.0 \pm 2.3(\mathrm{MSWD}=0.62)$ & $28.42 \pm 0.35(\mathrm{MSWD}=1.3)$ \\
\hline 17IONF-2 & $343.6 \pm 2.9(\mathrm{MSWD}=0.50)$ & $28.77 \pm 0.35(\mathrm{MSWD}=1.9)$ \\
\hline 15MD01/15SP1 & $338.3 \pm 2.1(\mathrm{MSWD}=1.6)$ & $29.12 \pm 0.37(\mathrm{MSWD}=1.4)$ \\
\hline 15MD02 & $343.9 \pm 3.2(\mathrm{MSWD}=1.3)$ & $28.39 \pm 0.59(\mathrm{MSWD}=1.5)$ \\
\hline 17BUT-1 & $341.1 \pm 3.0(\mathrm{MSWD}=0.69)$ & $28.12 \pm 0.42(\mathrm{MSWD}=0.69)$ \\
\hline 17SIM-1/17CWSS-2 & $337.3 \pm 2.5(\mathrm{MSWD}=1.0)$ & $28.89 \pm 0.45(\mathrm{MSWD}=0.72)$ \\
\hline 17JUN-2/17TSSG-1 & $341.8 \pm 2.6(\mathrm{MSWD}=0.77)$ & $28.61 \pm 0.40(\mathrm{MSWD}=1.6)$ \\
\hline Accepted Ages: & $337.13 \pm 0.37 \mathrm{Ma}($ Slama et al., 2008) & $28.402 \pm 0.023 \mathrm{Ma}$ Wotzlaw et al., 2013 \\
\hline
\end{tabular}

Appendix 4. U-Pb Zircon Data \& Concordia Plots 


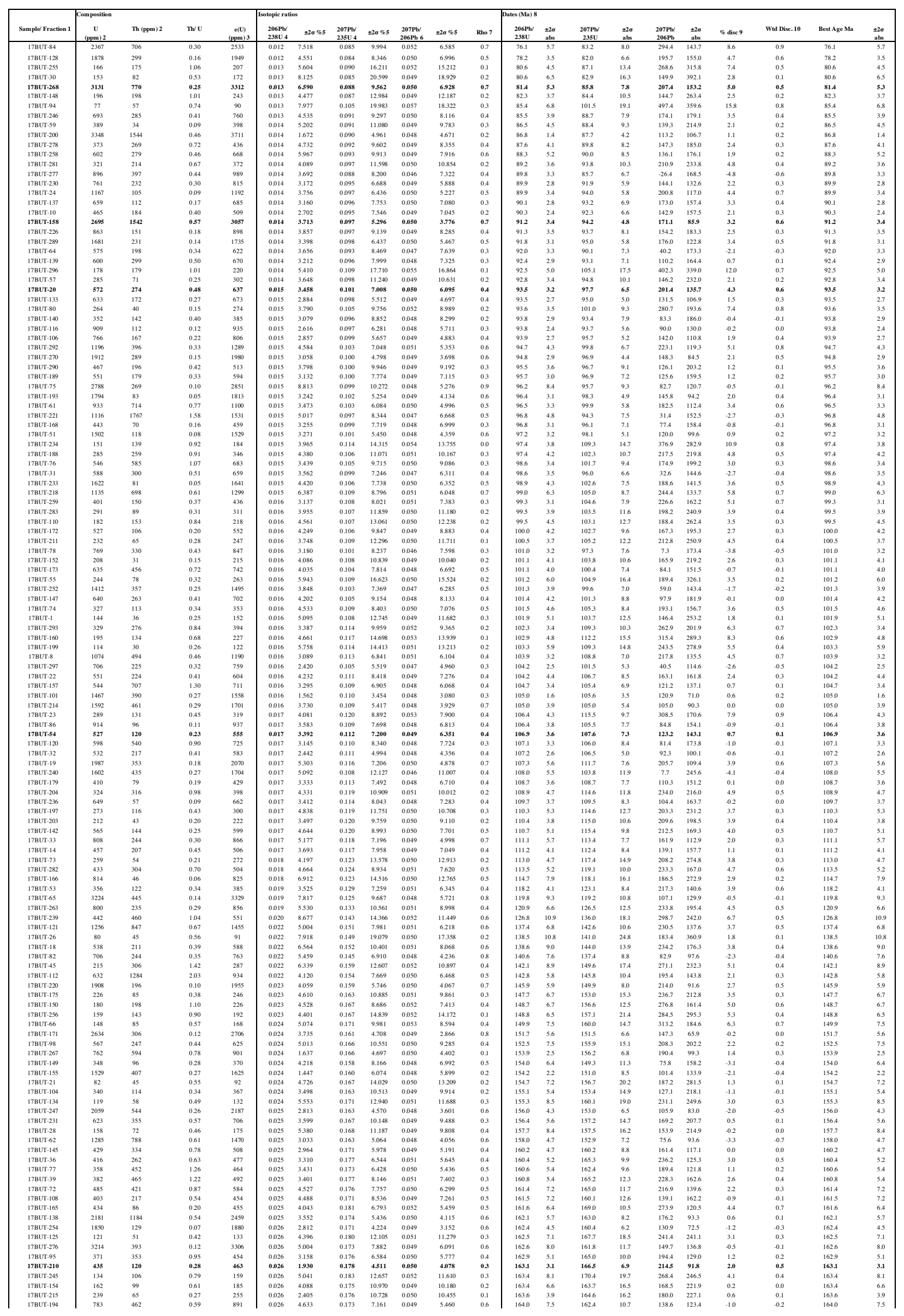




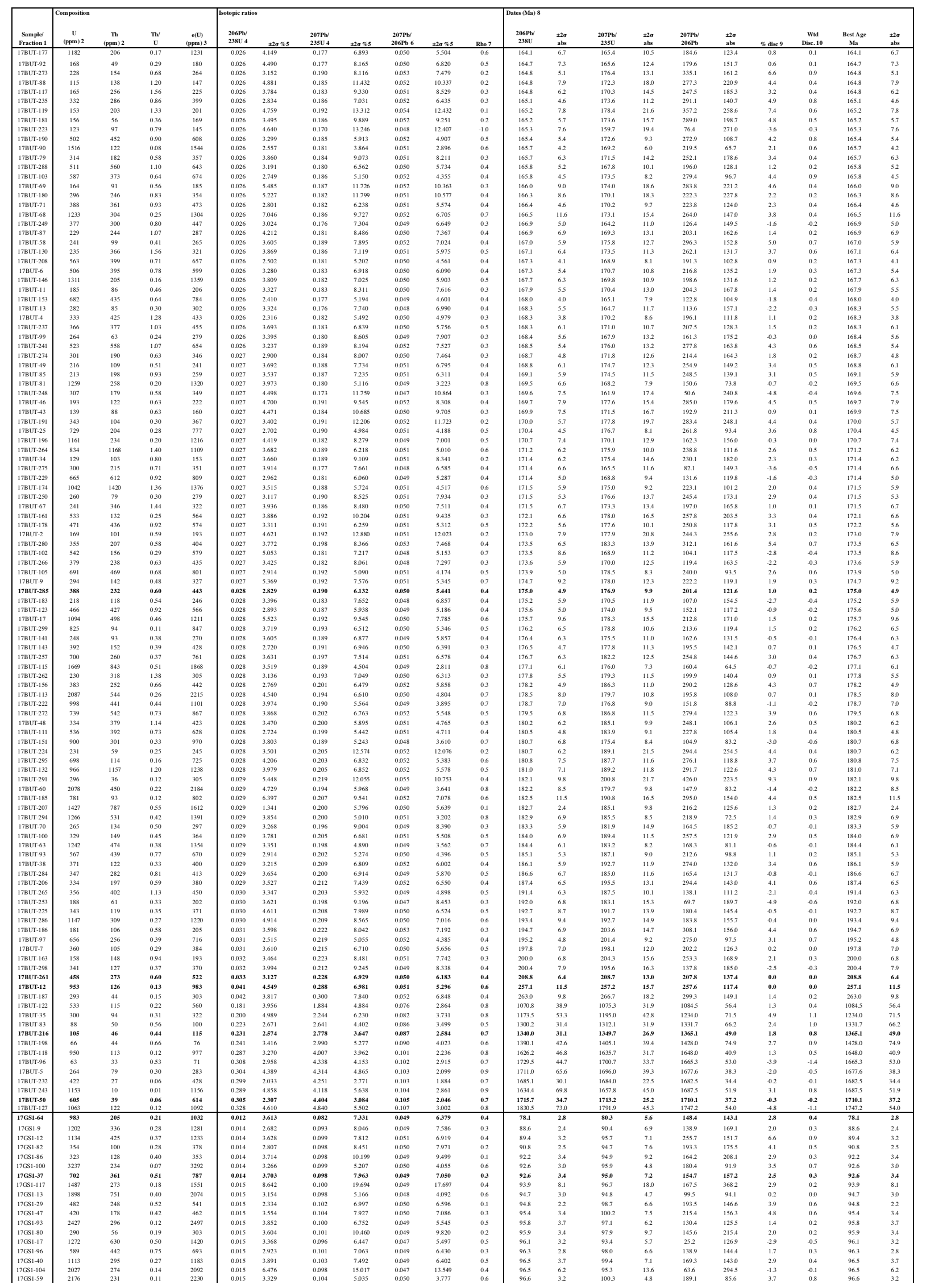




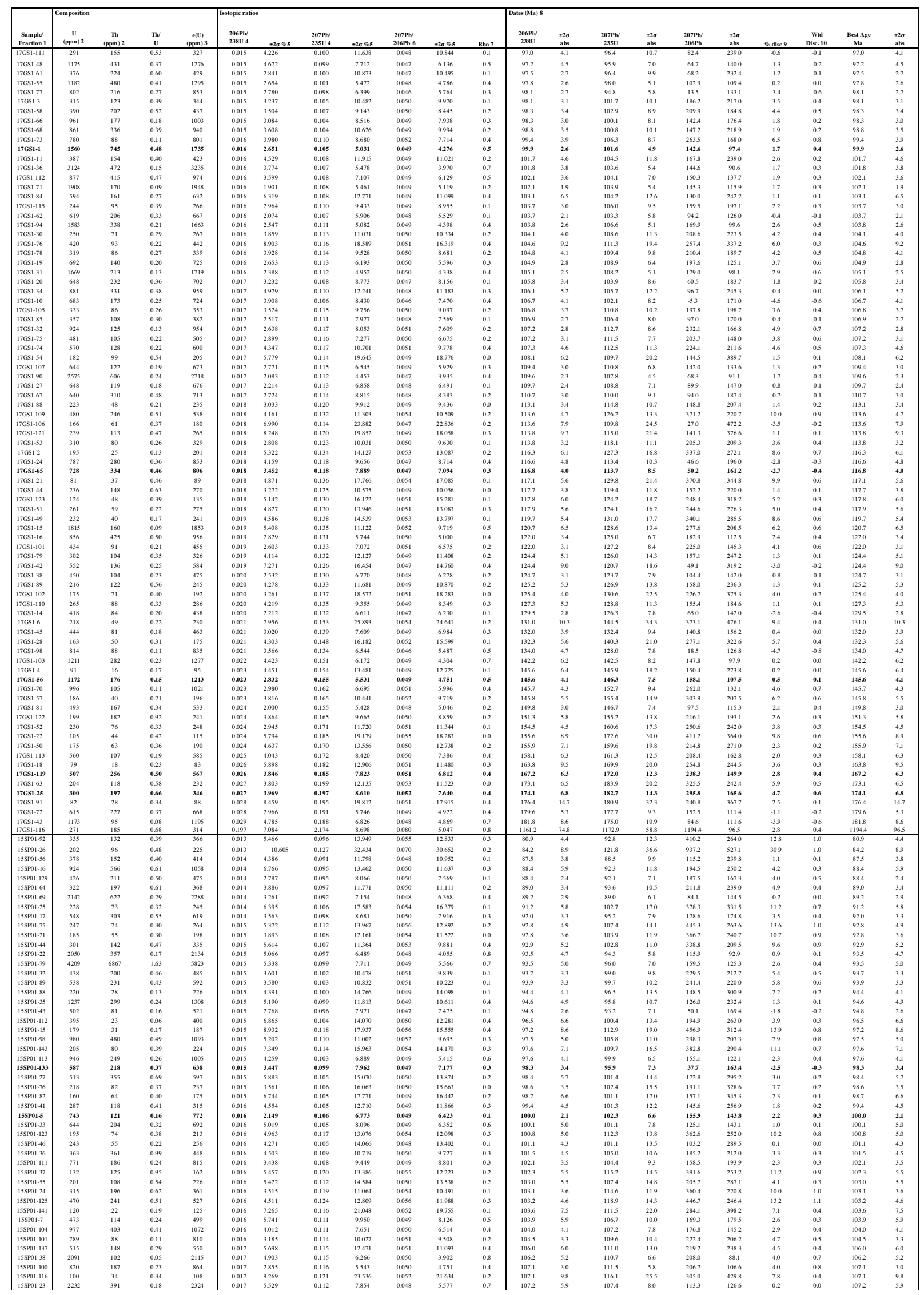




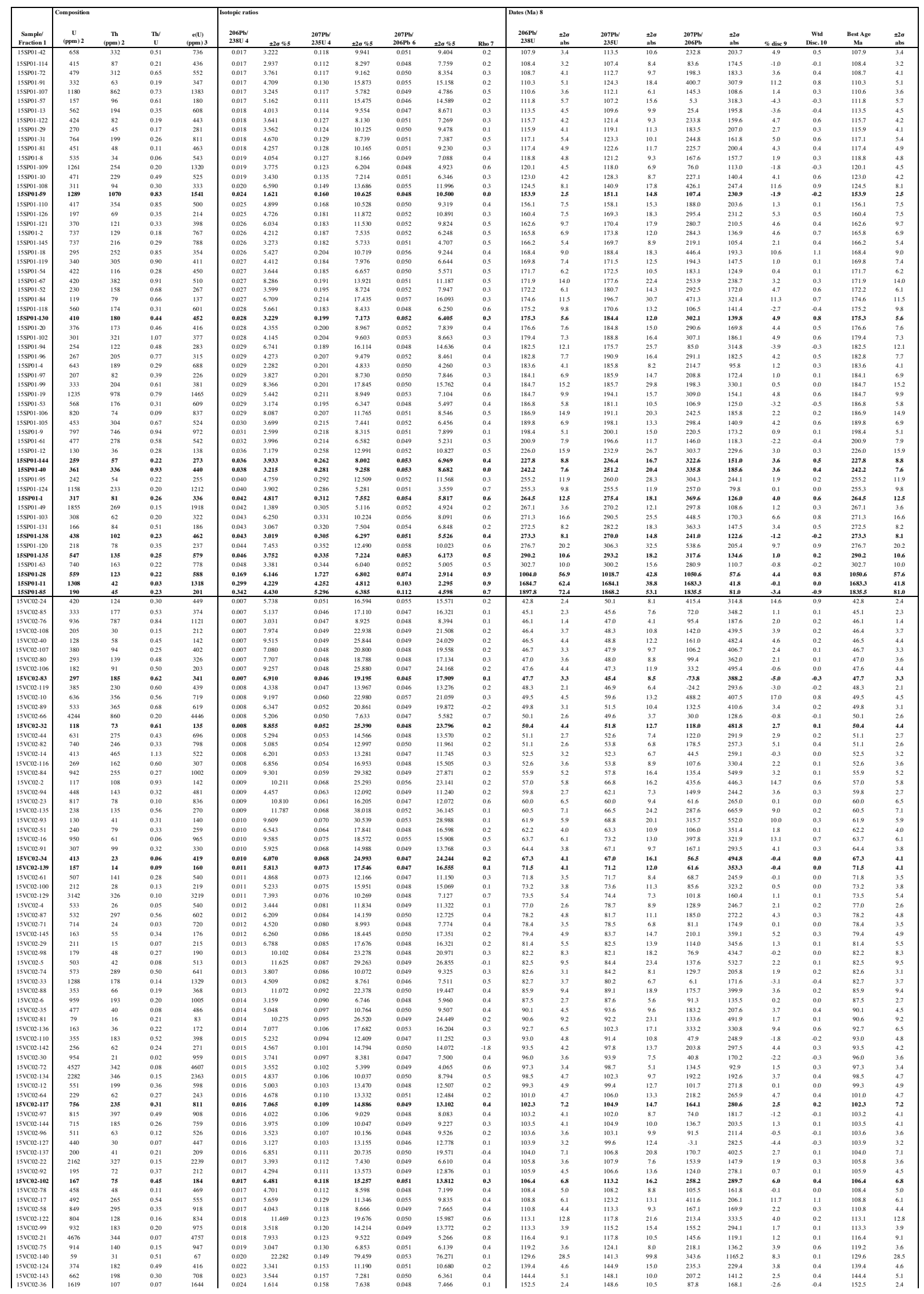




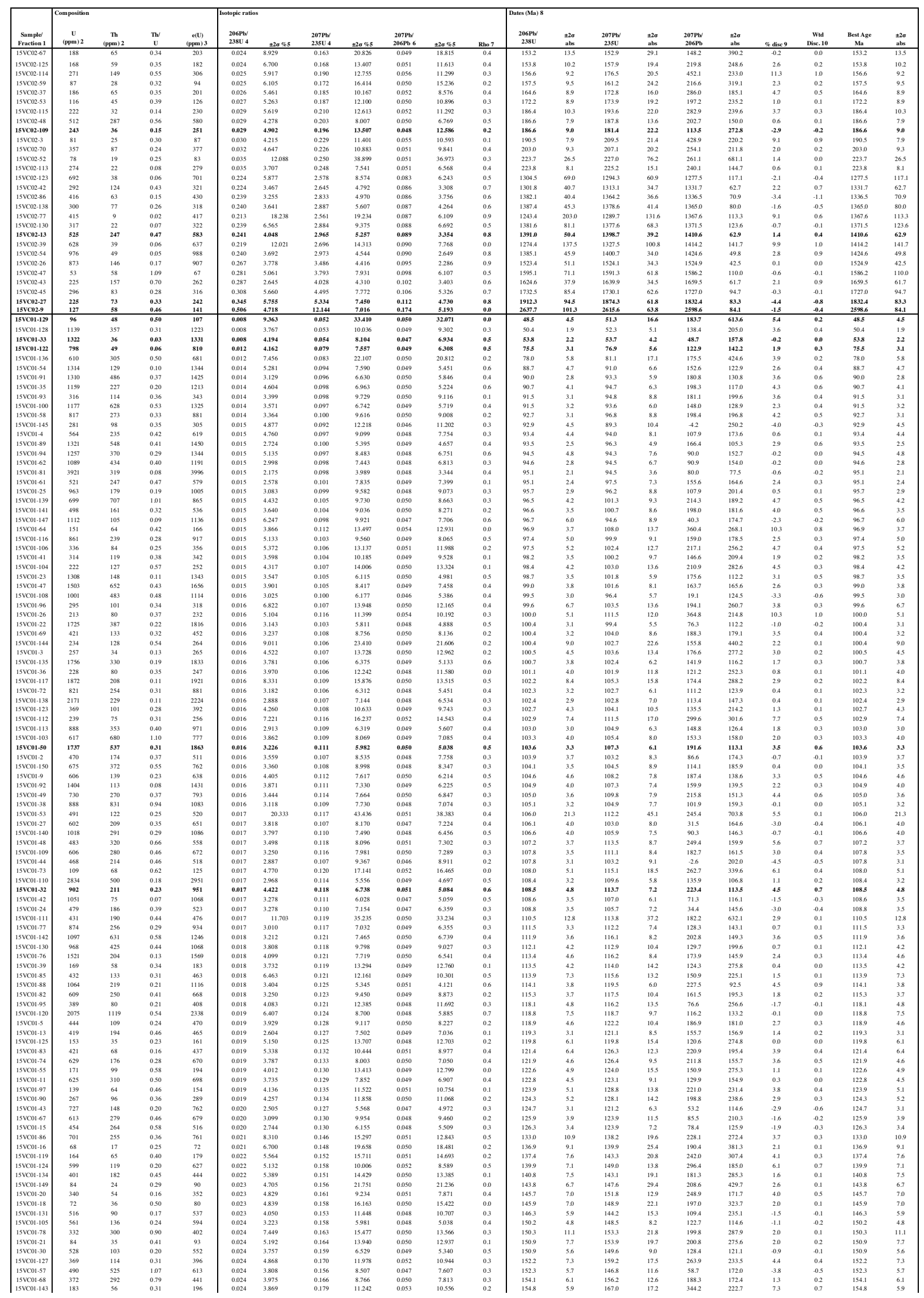




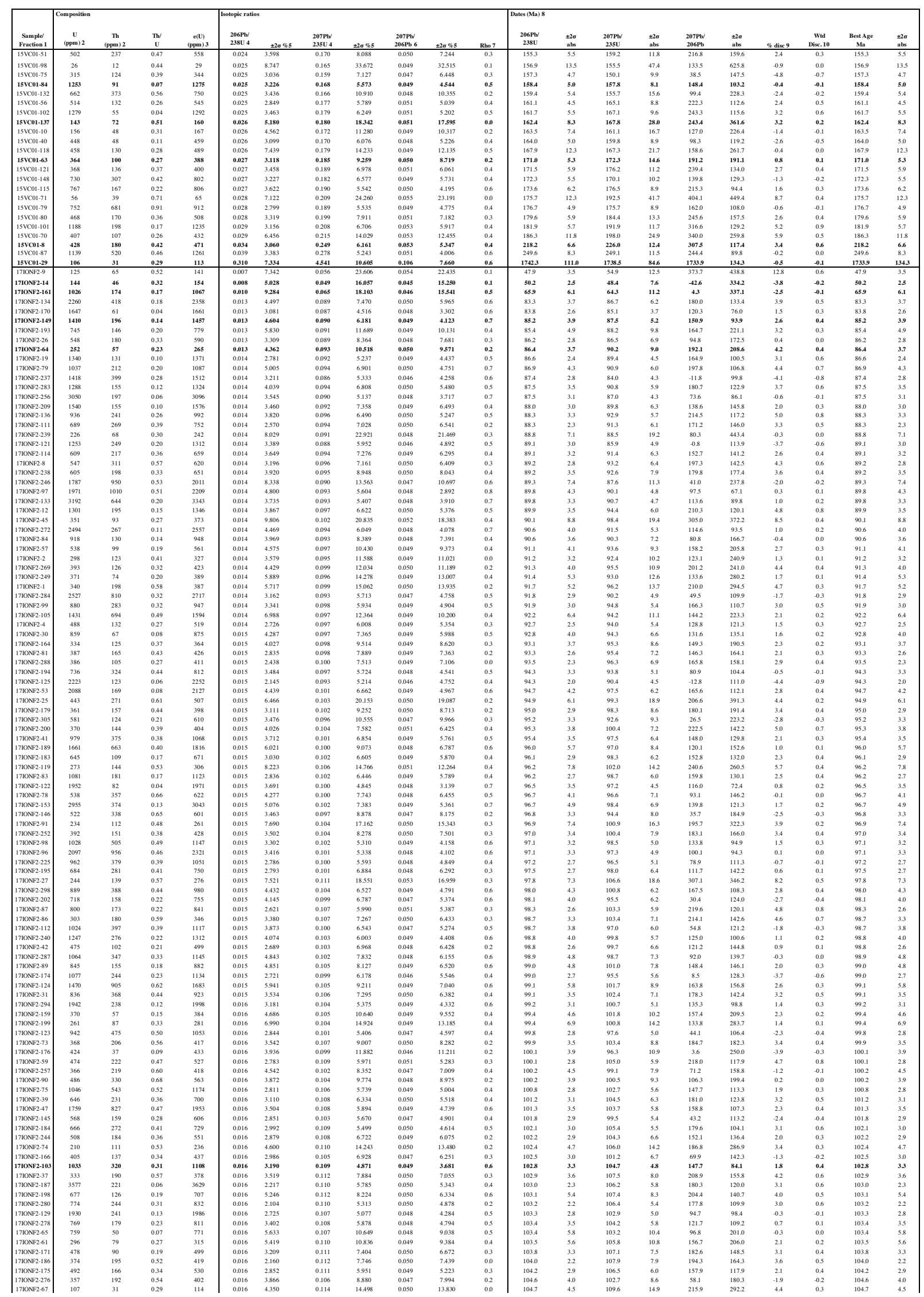




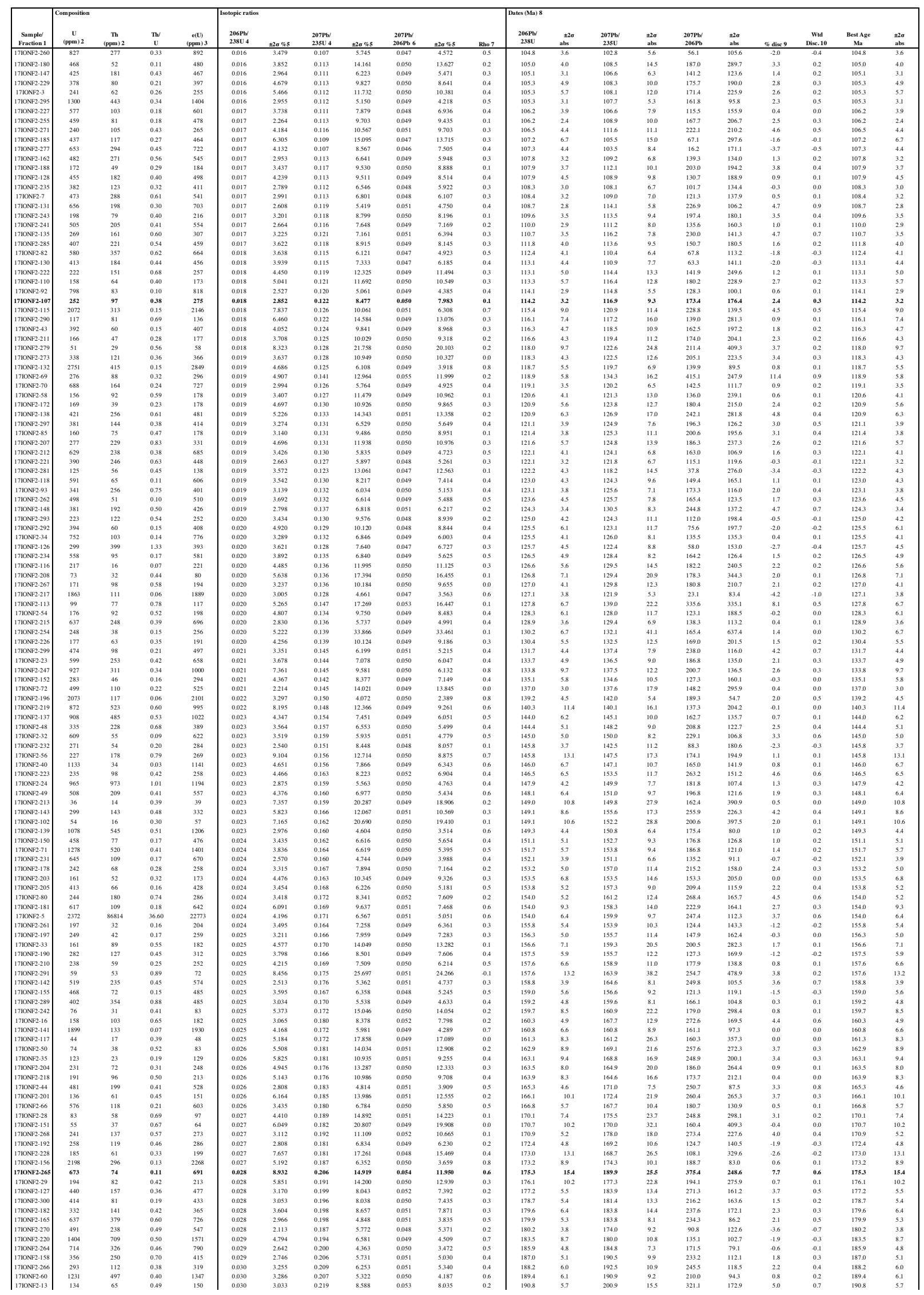




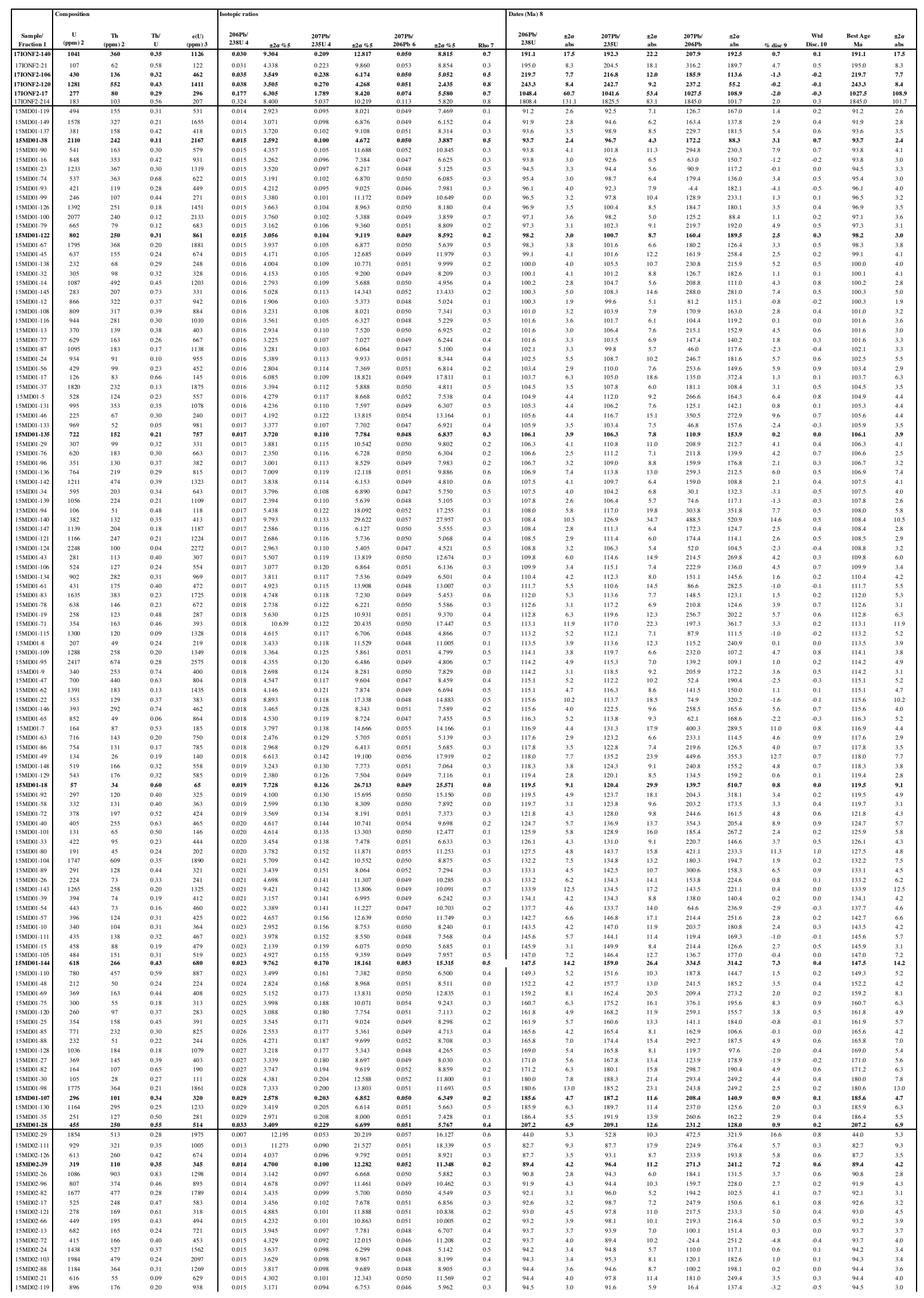




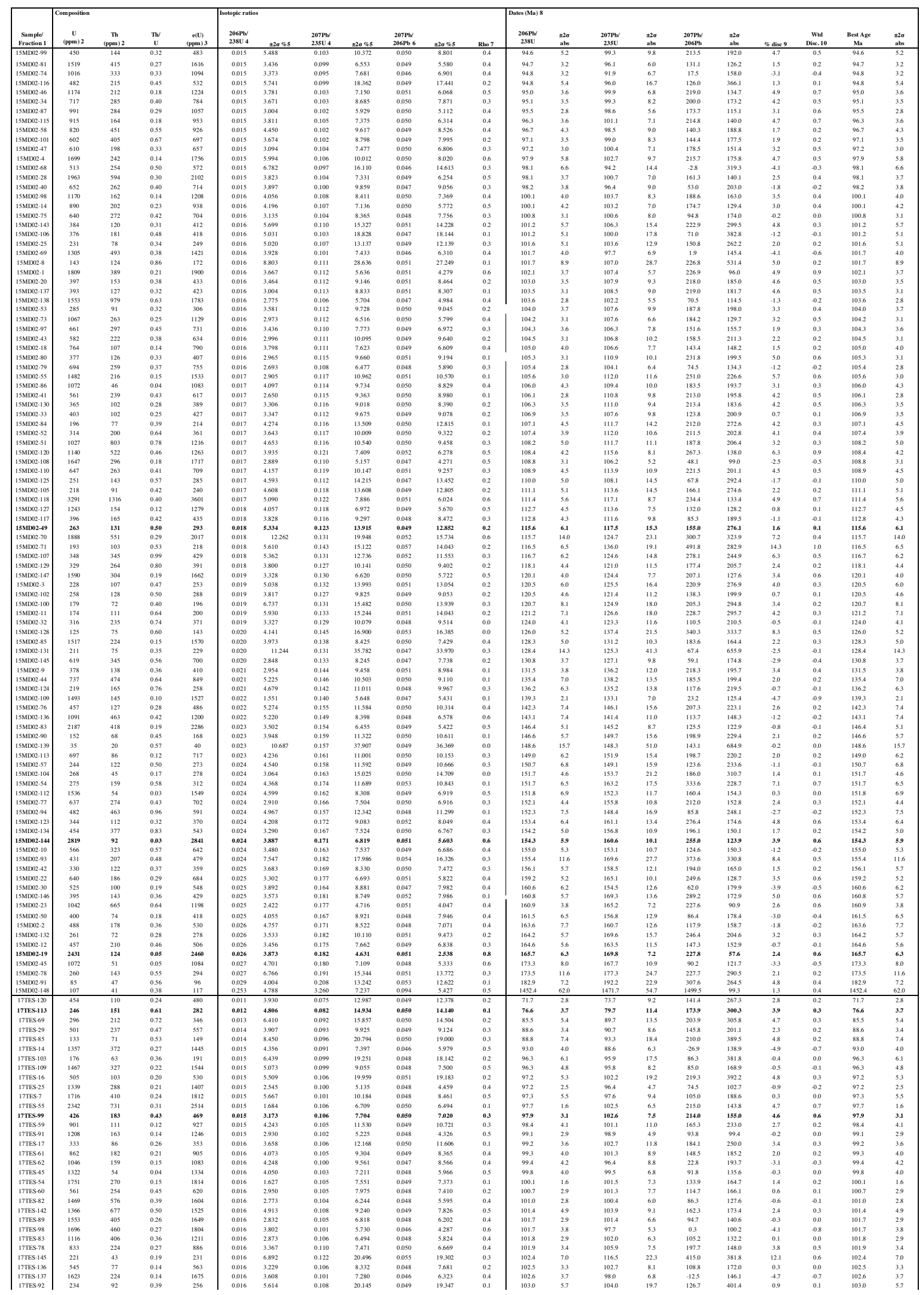




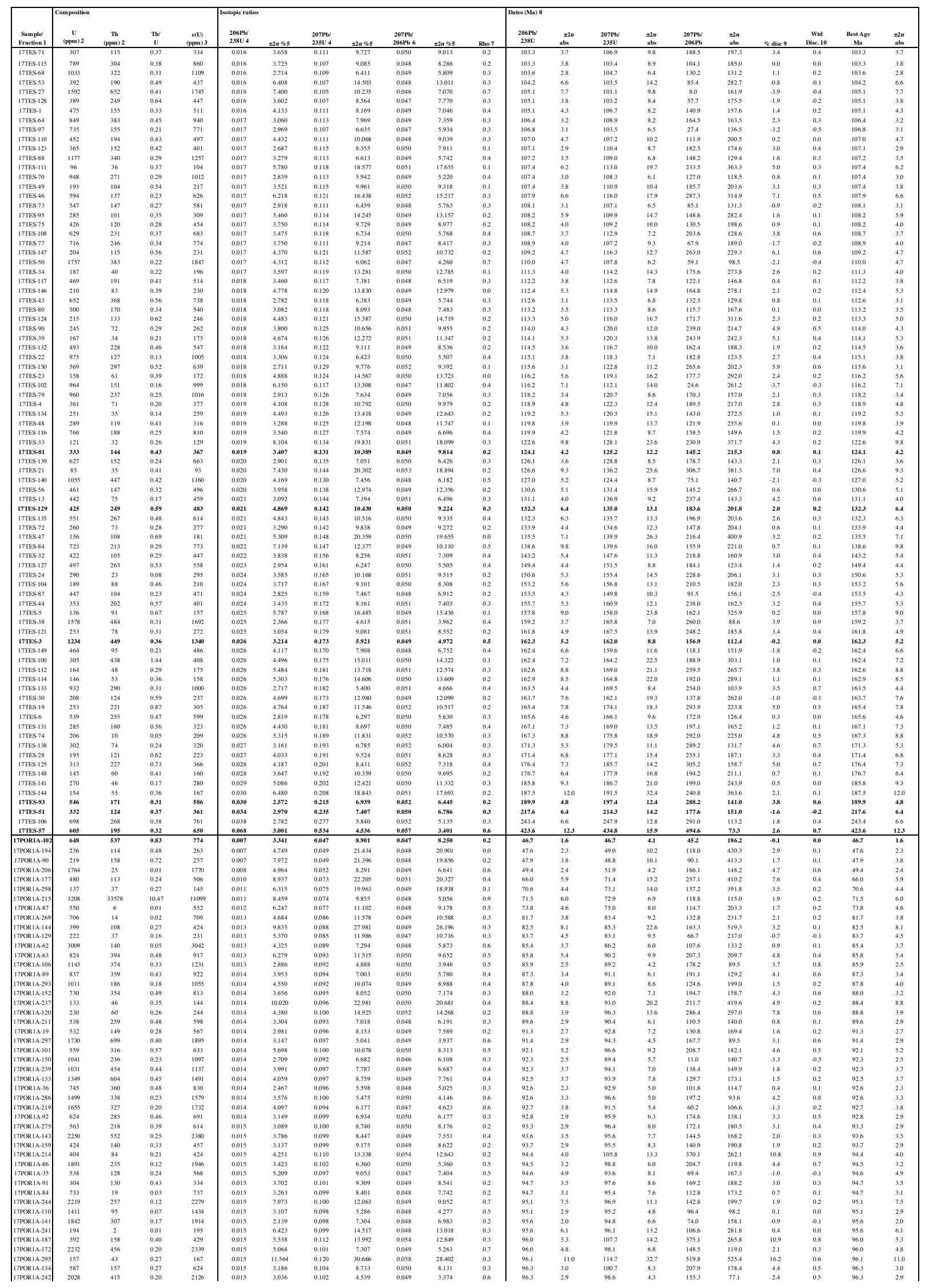




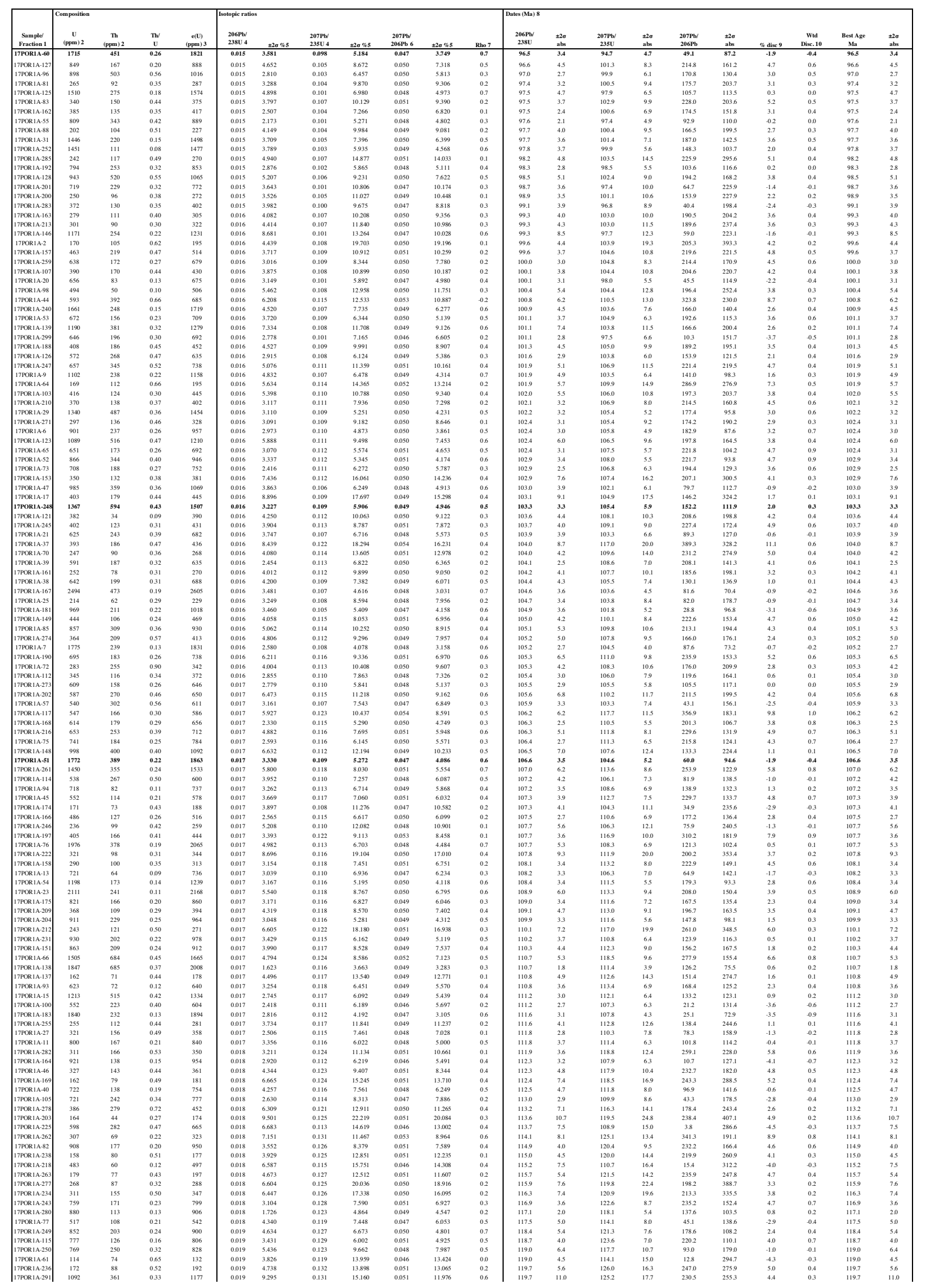




\begin{tabular}{|c|c|c|c|c|c|c|c|c|c|c|c|c|c|c|c|c|c|c|c|c|}
\hline 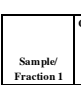 & $\underset{\text { pomm } 12}{\mathrm{u}}$ & 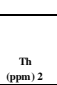 & 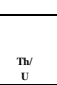 & 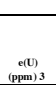 & 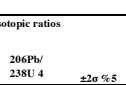 & 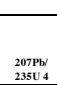 & & 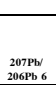 & & & 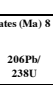 & 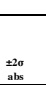 & 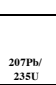 & 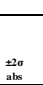 & 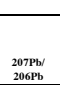 & 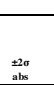 & & 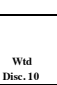 & $\begin{array}{c}\text { Best Age } \\
\text { Mag }\end{array}$ & 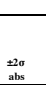 \\
\hline 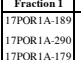 & 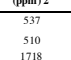 & $\begin{array}{l}131 \\
141\end{array}$ & $\begin{array}{l}026 \\
0.00\end{array}$ & 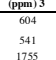 & 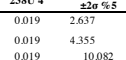 & 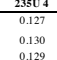 & 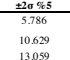 & 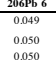 & 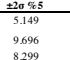 & $\begin{array}{l}0.3 \\
0.3\end{array}$ & 1000 & 52 & 1242 & 124 & $\begin{array}{l}18033 \\
2059 \\
2059\end{array}$ & 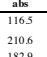 & 34 & 0.3 & 1200. & 52 \\
\hline 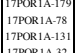 & $\begin{array}{c}1718 \\
113 \\
1,33 \\
133\end{array}$ & $\begin{array}{l}154 \\
65 \\
5 s\end{array}$ & $\begin{array}{l}0.009 \\
\text { of } \\
\text { o.3 }\end{array}$ & 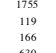 & 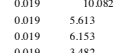 & $\begin{array}{l}0.129 \\
\text { o.132 } \\
0.139\end{array}$ & 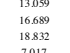 & $\begin{array}{l}0.050 \\
\text { o.055 } \\
0.054\end{array}$ & 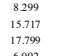 & $\begin{array}{l}0.8 \\
0.02 \\
02\end{array}$ & 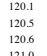 & $\begin{array}{l}120 \\
6.7 \\
73 \\
73\end{array}$ & 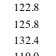 & $\begin{array}{l}1,109 \\
1969 \\
231.1\end{array}$ & 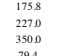 & 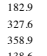 & $\begin{array}{l}22 \\
42 \\
89 \\
89\end{array}$ & $\begin{array}{l}0.2 \\
0.3 \\
0.5\end{array}$ & 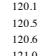 & $\begin{array}{l}120 \\
67 \\
73 \\
73\end{array}$ \\
\hline 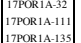 & 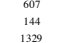 & 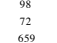 & $\begin{array}{l}0.160 \\
\text { ofs } \\
\text { ons }\end{array}$ & 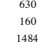 & 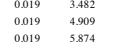 & 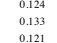 & 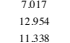 & 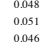 & 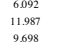 & 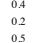 & 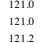 & 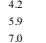 & 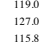 & 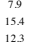 & 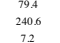 & 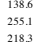 & $\begin{array}{ll}-17 \\
47 \\
46\end{array}$ & 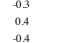 & 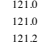 & $\begin{array}{l}42 \\
50 \\
70\end{array}$ \\
\hline 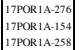 & $\begin{array}{c}556 \\
355 \\
356 \\
356\end{array}$ & $\begin{array}{l}1.99 \\
110 \\
110\end{array}$ & $\begin{array}{l}0.25 \\
0.25 \\
0.29\end{array}$ & 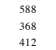 & 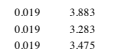 & $\begin{array}{l}0.130 \\
0.134 \\
0.126\end{array}$ & 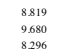 & $\begin{array}{l}0.050 \\
0.051 \\
0.048\end{array}$ & $\begin{array}{l}7918 \\
9.106 \\
7.533\end{array}$ & $\begin{array}{l}0.3 \\
0.1 \\
0.3\end{array}$ & $\begin{array}{l}1212 \\
21213 \\
2113 \\
213\end{array}$ & $\begin{array}{l}4.7 \\
39 \\
42\end{array}$ & 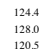 & $\begin{array}{l}1033 \\
116 \\
94\end{array}$ & 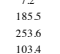 & 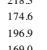 & $\begin{array}{l}26 \\
52 \\
58\end{array}$ & $\begin{array}{l}0.3 \\
0.3 \\
0.6\end{array}$ & $\begin{array}{l}1212 \\
1212 \\
1213\end{array}$ & $\begin{array}{l}317 \\
397 \\
3.7\end{array}$ \\
\hline 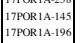 & $\begin{array}{l}213 \\
113 \\
113\end{array}$ & $\begin{array}{l}110 \\
\text { 115 } \\
83\end{array}$ & $\begin{array}{l}\text { ofs } \\
\text { os } \\
0.37\end{array}$ & 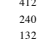 & 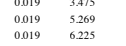 & 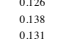 & 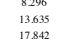 & 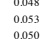 & 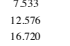 & $\begin{array}{l}0.03 \\
03 \\
02\end{array}$ & 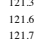 & $\begin{array}{l}42 \\
63 \\
75\end{array}$ & $\begin{array}{l}125.5 \\
132 \\
1249\end{array}$ & $\begin{array}{l}9.4 \\
1.60 \\
208\end{array}$ & 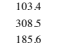 & 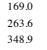 & $\begin{array}{l}\text { 年7 } \\
2.3 \\
25\end{array}$ & $\begin{array}{l}0.1 \\
0.6 \\
0.2\end{array}$ & $\begin{array}{l}1213 \\
121.1 \\
121.7\end{array}$ & $\begin{array}{l}42 \\
63 \\
75 \\
75\end{array}$ \\
\hline 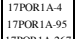 & $\begin{array}{l}5.4 \\
162 \\
162\end{array}$ & $\begin{array}{l}21 \\
66 \\
66\end{array}$ & $\begin{array}{l}\text { ont } \\
\text { oat }\end{array}$ & $\begin{array}{l}5,59 \\
177\end{array}$ & 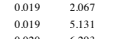 & $\begin{array}{l}0.123 \\
0.136 \\
0.136\end{array}$ & $\begin{array}{l}6013 \\
15319 \\
\text { 15319 }\end{array}$ & $\begin{array}{l}0.047 \\
0.051\end{array}$ & $\begin{array}{l}5.577 \\
1.434\end{array}$ & $\begin{array}{l}0.1 \\
0.1 \\
0.1\end{array}$ & $\begin{array}{l}124 \\
1224 \\
124\end{array}$ & $\begin{array}{l}25 \\
6.3 \\
6.3\end{array}$ & $\begin{array}{l}{ }_{1179} \\
1298\end{array}$ & $\begin{array}{l}6.7 \\
185 \\
185\end{array}$ & $\begin{array}{l}2801 \\
2313\end{array}$ & 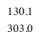 & $\begin{array}{l}3.8 \\
42 \\
42\end{array}$ & $\begin{array}{l}-0.7 \\
0.3\end{array}$ & $\begin{array}{l}122,4 \\
1244\end{array}$ & $\begin{array}{l}25 \\
63 \\
63\end{array}$ \\
\hline 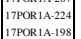 & 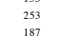 & 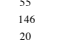 & $\begin{array}{l}\text { ofs } \\
\text { oss } \\
\text { oul }\end{array}$ & 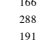 & 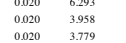 & $\begin{array}{l}0.137 \\
0.137 \\
0.130\end{array}$ & 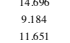 & 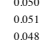 & 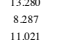 & 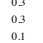 & 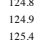 & $\begin{array}{l}78 \\
49 \\
47\end{array}$ & 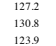 & $\begin{array}{l}174 \\
112 \\
1,3\end{array}$ & 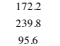 & 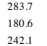 & $\begin{array}{l}19 \\
4.5 \\
.12\end{array}$ & $\begin{array}{l}0.5 \\
0.5 \\
0.1 \\
0.1\end{array}$ & 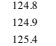 & $\begin{array}{l}78 \\
49 \\
47\end{array}$ \\
\hline 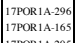 & 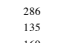 & 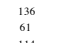 & $\begin{array}{l}0.47 \\
0.45\end{array}$ & $\begin{array}{l}318 \\
140 \\
140\end{array}$ & 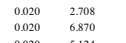 & 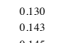 & 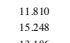 & 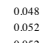 & 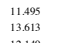 & $\begin{array}{l}0,1 \\
04\end{array}$ & 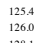 & $\begin{array}{l}34 \\
86\end{array}$ & 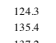 & $\begin{array}{l}1037 \\
192\end{array}$ & 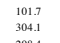 & 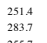 & $\begin{array}{l}-100 \\
70 \\
70\end{array}$ & $\begin{array}{l}-0.1 \\
0.5\end{array}$ & $\begin{array}{l}121544 \\
12600\end{array}$ & $\begin{aligned} 3.5 \\
86 \\
86\end{aligned}$ \\
\hline 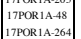 & $\begin{array}{l}482 \\
4828 \\
785\end{array}$ & $\begin{array}{l}139 \\
3.14 \\
3.4\end{array}$ & 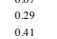 & $\begin{array}{l}\text { sis } \\
\text { sit2 } \\
\text { s.t. }\end{array}$ & 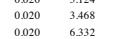 & 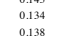 & 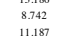 & 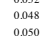 & 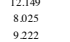 & 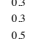 & 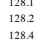 & $\begin{array}{l}63 \\
64\end{array}$ & $\begin{array}{l}1327 \\
1275 \\
\text { and }\end{array}$ & 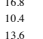 & 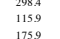 & 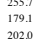 & 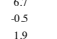 & 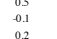 & 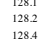 & $\begin{array}{l}0.5 \\
4.4 \\
80\end{array}$ \\
\hline 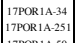 & $\begin{array}{l}203 \\
116 \\
116\end{array}$ & $\begin{array}{l}72 \\
42 \\
42\end{array}$ & 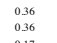 & $\begin{array}{l}220 \\
125 \\
125 \\
\end{array}$ & $\begin{array}{ll}0.0211 \\
0021 \\
0.021\end{array}$ & $\begin{array}{l}0.146 \\
0.135 \\
0.15\end{array}$ & 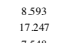 & $\begin{array}{l}0.0051 \\
0052 \\
0.52\end{array}$ & 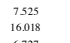 & $\begin{array}{l}0.3 \\
02\end{array}$ & $\begin{array}{l}1824 \\
182,4 \\
1864\end{array}$ & $\begin{array}{l}54 \\
86\end{array}$ & 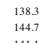 & $\begin{array}{l}1100 \\
2300\end{array}$ & $\begin{array}{l}24200 \\
2820 \\
2820\end{array}$ & $\begin{array}{l}10488 \\
30202 \\
3.02\end{array}$ & $\begin{array}{l}42 \\
57\end{array}$ & $\begin{array}{l}0.5 \\
0.4 \\
0.4\end{array}$ & 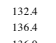 & $\begin{array}{l}5.4 \\
865\end{array}$ \\
\hline & & & & & 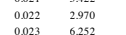 & 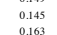 & $\begin{array}{l}7548 \\
5,41\end{array}$ & $\begin{array}{l}0.050 \\
0.447\end{array}$ & $\begin{array}{l}6.727 \\
4.642 \\
4.642\end{array}$ & & $\begin{array}{l}1869 \\
1,242 \\
1.24\end{array}$ & 42 & 1375 & 7.1 & $\begin{array}{l}2108 \\
540 \\
305\end{array}$ & 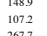 & $\begin{array}{l}29 \\
.36 \\
.36\end{array}$ & $\begin{array}{l}0.4 \\
0.7\end{array}$ & $\begin{array}{l}\frac{1369}{1342} \\
142.4\end{array}$ & $\begin{array}{l}46 \\
42 \\
42\end{array}$ \\
\hline 羊 & 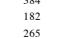 & $\begin{array}{l}190 \\
1001 \\
1.1\end{array}$ & 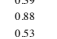 & $\begin{array}{l}419 \\
2198 \\
2.89\end{array}$ & 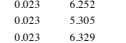 & 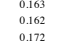 & 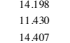 & 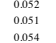 & 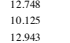 & $\begin{array}{l}0.04 \\
0.3 \\
02\end{array}$ & 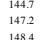 & $\begin{array}{l}89 \\
7,7 \\
0,3\end{array}$ & 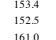 & 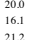 & 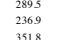 & 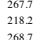 & $\begin{array}{l}56 \\
35 \\
79\end{array}$ & $\begin{array}{l}0.04 \\
03 \\
0.6\end{array}$ & 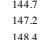 & 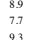 \\
\hline 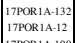 & $\begin{array}{l}737 \\
337\end{array}$ & $\begin{array}{l}31 \\
234 \\
254\end{array}$ & $\begin{array}{l}0.42 \\
0.44 \\
0.45\end{array}$ & $\begin{array}{l}800 \\
457 \\
457\end{array}$ & 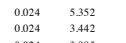 & $\begin{array}{l}0.170 \\
0,172 \\
0.12\end{array}$ & 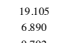 & $\begin{array}{l}0.0052 \\
00522 \\
0.52\end{array}$ & 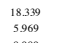 & $\begin{array}{l}02 \\
04 \\
04\end{array}$ & 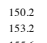 & $\begin{array}{l}79 \\
52\end{array}$ & 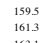 & $\begin{array}{l}2788 \\
102\end{array}$ & 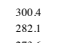 & $\begin{array}{l}3719 \\
\text { sil. }\end{array}$ & $\begin{array}{l}58 \\
50 \\
50\end{array}$ & $\begin{array}{l}0.3 \\
0.8\end{array}$ & 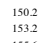 & $\begin{array}{l}79 \\
52 \\
52\end{array}$ \\
\hline 它 & 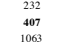 & 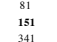 & $\begin{array}{l}0.035 \\
\text { os } \\
\text { ang }\end{array}$ & 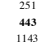 & 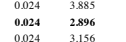 & $\begin{array}{l}0.174 \\
0.113 \\
\text { ond }\end{array}$ & 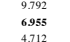 & 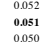 & 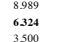 & $\begin{array}{l}0.3 \\
0.3 \\
0.6\end{array}$ & 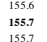 & $\begin{array}{ll}60 \\
45 \\
40\end{array}$ & 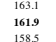 & 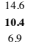 & 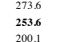 & 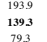 & $\begin{array}{l}46 \\
38 \\
3,5\end{array}$ & $\begin{array}{l}0.0 \\
0.6 \\
0.4\end{array}$ & 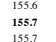 & $\begin{array}{ll}60 \\
45 \\
40\end{array}$ \\
\hline 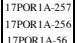 & $\begin{array}{ll}6090 \\
67 \\
207\end{array}$ & 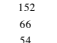 & 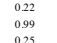 & 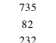 & 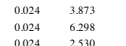 & $\begin{array}{l}0.167 \\
\text { ortr } \\
0.17\end{array}$ & 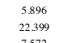 & 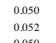 & 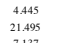 & $\begin{array}{l}0.6 \\
0.1\end{array}$ & 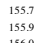 & $\begin{array}{l}60 \\
97 \\
97\end{array}$ & 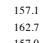 & $\begin{array}{l}851 \\
331 \\
331\end{array}$ & 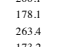 & 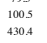 & 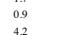 & 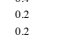 & 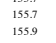 & 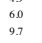 \\
\hline 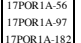 & $\begin{array}{ll}2109 \\
\text { 198 } \\
\text { s.t. }\end{array}$ & 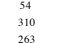 & $\begin{array}{ll}0.25 \\
1506 \\
\text { ond }\end{array}$ & 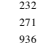 & 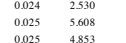 & 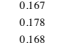 & 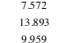 & 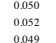 & 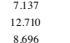 & $\begin{array}{l}0.1 \\
0.3 \\
0.5\end{array}$ & 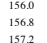 & $\begin{array}{l}39 \\
87 \\
75\end{array}$ & 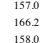 & 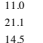 & 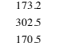 & 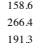 & $\begin{array}{l}0.7 \\
57 \\
0.5\end{array}$ & $\begin{array}{l}0.1 \\
0.1 \\
0.4\end{array}$ & 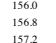 & $\begin{array}{l}39 \\
87 \\
75\end{array}$ \\
\hline 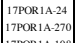 & $\begin{array}{l}742 \\
\text { 12919 }\end{array}$ & $\begin{array}{l}400 \\
200 \\
200\end{array}$ & $\begin{array}{l}0.57 \\
0.54\end{array}$ & $\begin{array}{l}7.83 \\
\text { s.t56 }\end{array}$ & $\begin{array}{ll}0.0255 \\
0.025 \\
0.025 & 4726 \\
3\end{array}$ & 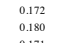 & $\begin{array}{l}7.7808 \\
6.152 \\
6.52\end{array}$ & 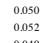 & 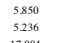 & $\begin{array}{l}06 \\
0.5 \\
0.5\end{array}$ & 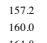 & $\begin{array}{l}77 \\
5.15 \\
5.1\end{array}$ & $\begin{array}{l}1608 \\
1676 \\
1676\end{array}$ & 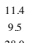 & $\begin{array}{l}21166 \\
2773 \\
273\end{array}$ & 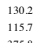 & $\begin{array}{l}22 \\
46 \\
46\end{array}$ & $\begin{array}{l}0.3 \\
0.8 \\
0.8\end{array}$ & $\begin{array}{l}15127 \\
16000 \\
1000\end{array}$ & $\begin{array}{l}77 \\
51 \\
51.1\end{array}$ \\
\hline 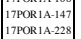 & 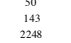 & 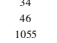 & 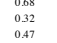 & 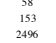 & 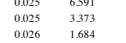 & 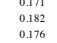 & 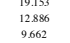 & 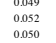 & 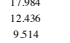 & $\begin{array}{l}01 \\
0.1 \\
01\end{array}$ & 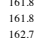 & $\begin{array}{l}103 \\
5.4 \\
27\end{array}$ & 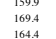 & $\begin{array}{l}2109 \\
1996 \\
1.46\end{array}$ & 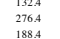 & 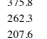 & $\begin{array}{l}-12 \\
45 \\
10\end{array}$ & $\begin{array}{l}0.1 \\
0.4 \\
0.1\end{array}$ & 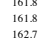 & $\begin{array}{l}1 \\
5.43 \\
27\end{array}$ \\
\hline & $\begin{array}{l}671 \\
345\end{array}$ & 100 & $\begin{array}{l}0.05 \\
0.22 \\
0.25\end{array}$ & $\begin{array}{l}680 \\
3011 \\
311\end{array}$ & & 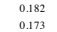 & $\begin{array}{l}9.9770 \\
6.562\end{array}$ & $\begin{array}{l}0.051 \\
0.048 \\
0.48\end{array}$ & $\begin{array}{l}8955 \\
59957 \\
5907\end{array}$ & $\begin{array}{l}0.4 \\
0.3\end{array}$ & $\begin{array}{l}1684 \\
\text { cisi }\end{array}$ & & 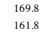 & $\begin{array}{l}153 \\
98 \\
98\end{array}$ & $\begin{array}{l}2595 \\
1169 \\
1169\end{array}$ & 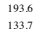 & & & 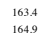 & 6.7 \\
\hline 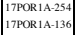 & $\begin{array}{l}1366 \\
326\end{array}$ & $\begin{array}{l}83 \\
151 \\
151\end{array}$ & $\begin{array}{l}0.61 \\
0.46 \\
0.04\end{array}$ & 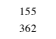 & 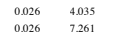 & $\begin{array}{l}0.178 \\
0.135 \\
0.135\end{array}$ & $\begin{array}{l}13.121 \\
19.13 \\
13\end{array}$ & $\begin{array}{l}0.055 \\
0.552 \\
0.52\end{array}$ & $\begin{array}{l}127960 \\
1.7580\end{array}$ & $\begin{array}{l}00 \\
0.3 \\
0.3\end{array}$ & $\begin{array}{l}1603 \\
1058 \\
1058\end{array}$ & $\begin{array}{l}6.69 \\
119\end{array}$ & 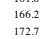 & $\begin{array}{l}1999 \\
1999\end{array}$ & 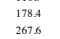 & 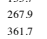 & $\begin{array}{l}0.5 \\
40\end{array}$ & $\begin{array}{l}0.0 \\
0.2 \\
0.20\end{array}$ & $\begin{array}{l}1653 \\
1658 \\
158\end{array}$ & 6.6. \\
\hline 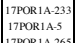 & 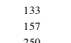 & 步 & $\begin{array}{l}0.052 \\
\text { os } \\
\text { sis }\end{array}$ & 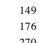 & 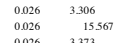 & $\begin{array}{l}0.192 \\
\text { ortr } \\
0.71\end{array}$ & 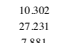 & $\begin{array}{l}0.0938 \\
0.047 \\
0.45\end{array}$ & 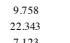 & $\begin{array}{l}0.1 \\
0.6\end{array}$ & 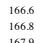 & $\begin{array}{l}5.5 \\
256 \\
256\end{array}$ & 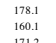 & 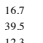 & $\begin{array}{l}342 \\
622 \\
6221\end{array}$ & $\begin{array}{l}2.772 \\
\text { tors }\end{array}$ & $\begin{array}{l}6.5 \\
42 \\
42\end{array}$ & $\begin{array}{l}0.7 \\
0.02 \\
0.02\end{array}$ & 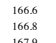 & $\begin{array}{l}\frac{54}{256} \\
256\end{array}$ \\
\hline 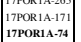 & $\begin{array}{l}7868 \\
386\end{array}$ & $\begin{array}{l}800 \\
100 \\
194\end{array}$ & $\begin{array}{l}0.27 \\
0.27 \\
0.717\end{array}$ & 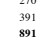 & 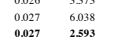 & 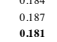 & 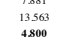 & 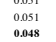 & 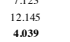 & $\begin{array}{l}0.4 \\
0.5 \\
0.5\end{array}$ & 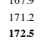 & $\begin{array}{l}102 \\
102 \\
44\end{array}$ & 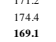 & $\begin{array}{l}215 \\
215 \\
74\end{array}$ & 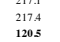 & 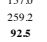 & $\begin{array}{l}1.8 \\
.21 \\
2.1\end{array}$ & $\begin{array}{ll}0.1 \\
0.5 \\
0.5\end{array}$ & 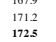 & $\begin{array}{l}\frac{102}{102} \\
44\end{array}$ \\
\hline 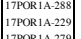 & 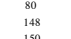 & $\begin{array}{l}28 \\
{ }_{33}^{28} \\
\end{array}$ & $\begin{array}{l}0.035 \\
036 \\
0.56\end{array}$ & $\begin{array}{l}870 \\
100 \\
100\end{array}$ & 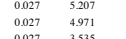 & 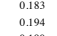 & $\begin{array}{l}1,5373 \\
12381\end{array}$ & $\begin{array}{l}0.049 \\
0.052\end{array}$ & 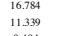 & $\begin{array}{l}0.1 \\
0.3\end{array}$ & 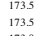 & $\begin{array}{l}89 \\
8.5 \\
\end{array}$ & $\begin{array}{l}1003 \\
18022 \\
1802\end{array}$ & $\begin{array}{l}2727 \\
202\end{array}$ & $\begin{array}{l}1262 \\
270.1 \\
2\end{array}$ & 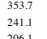 & $\begin{array}{l}-19 \\
3.8 \\
3.8\end{array}$ & $\begin{array}{l}-0.1 \\
0.3\end{array}$ & $\begin{array}{l}17755 \\
1735 \\
135\end{array}$ & $\begin{array}{l}8.9 \\
85\end{array}$ \\
\hline 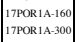 & 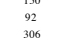 & 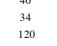 & 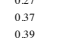 & 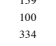 & 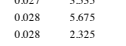 & 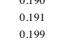 & 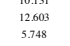 & 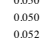 & 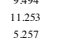 & 列 & 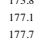 & 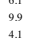 & 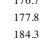 & 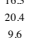 & 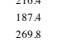 & 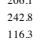 & $\begin{array}{l}\substack{0.4 \\
36} \\
3.0\end{array}$ & $\begin{array}{l}0.0 \\
0.7 \\
07\end{array}$ & 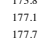 & 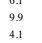 \\
\hline 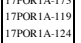 & 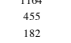 & $\begin{array}{l}161 \\
161 \\
112\end{array}$ & 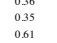 & 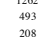 & 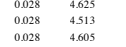 & $\begin{array}{l}0.197 \\
\text { o.920 } \\
\text { ond }\end{array}$ & 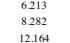 & 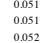 & 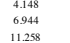 & $\begin{array}{l}0.0 \\
0.5 \\
03\end{array}$ & 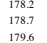 & 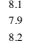 & 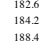 & 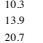 & 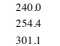 & 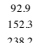 & 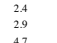 & $\begin{array}{ll}0.4 \\
0.4 \\
0.4\end{array}$ & 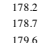 & $\begin{array}{l}81 \\
78 \\
8\end{array}$ \\
\hline 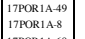 & $\begin{array}{l}1068 \\
1008\end{array}$ & $\begin{array}{l}70 \\
328 \\
328\end{array}$ & $\begin{array}{l}0.42 \\
030 \\
0.020\end{array}$ & $\begin{array}{l}185 \\
11155 \\
1175\end{array}$ & $\begin{array}{l}0.028 \\
0.030 \\
0.350\end{array}$ & $\begin{array}{l}0.193 \\
0206 \\
0.03\end{array}$ & 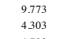 & $\begin{array}{l}\text { out9 } \\
\text { ouss }\end{array}$ & 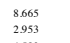 & $\begin{array}{l}0.3 \\
0.7\end{array}$ & $\begin{array}{l}1804 \\
1807 \\
1876\end{array}$ & $\begin{array}{l}80 \\
58 \\
58\end{array}$ & $\begin{array}{l}17922 \\
19000 \\
1000\end{array}$ & 望, & 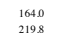 & $\begin{array}{l}1009 \\
1009\end{array}$ & 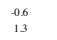 & $\begin{array}{l}0.1 \\
0.3 \\
0.0\end{array}$ & 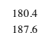 & $\begin{array}{l}80 \\
58 \\
58\end{array}$ \\
\hline 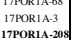 & 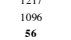 & $\begin{array}{l}205 \\
3195 \\
11\end{array}$ & 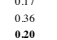 & 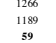 & 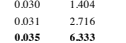 & 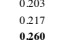 & 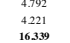 & 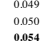 & 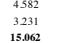 & $\begin{array}{l}0.2 \\
0.6 \\
0.2\end{array}$ & 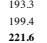 & $\begin{array}{l}27 \\
5.3 \\
138\end{array}$ & $\begin{array}{l}1880 \\
19972 \\
1927\end{array}$ & $\begin{array}{l}82 \\
76 \\
76\end{array}$ & $\begin{array}{l}1293 \\
20372 \\
2037\end{array}$ & $\begin{array}{l}1045 \\
773 \\
303\end{array}$ & $\begin{array}{l}-28 \\
0.2 \\
0.28\end{array}$ & 然. & $\begin{array}{l}193.3 \\
1994 \\
0904\end{array}$ & $\begin{array}{l}27 \\
53 \\
132\end{array}$ \\
\hline & 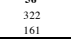 & $\begin{array}{l}120 \\
120 \\
134\end{array}$ & $\begin{array}{l}8.37 \\
0.37 \\
083\end{array}$ & 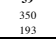 & 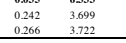 & 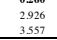 & 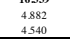 & 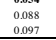 & 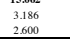 & & 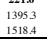 & 1662 & & $\begin{array}{l}3.563 \\
3.63 \\
3.45\end{array}$ & 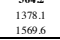 & 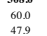 & 然 & $0 . A$ & 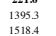 & 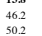 \\
\hline 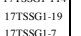 & 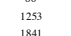 & $\begin{array}{l}600 \\
610 \\
510\end{array}$ & 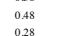 & 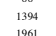 & & . 0084 & 6.388 & & & 0.4 & 778 & 23 & 81.6 & so & & & 4.7 & vis & 778 & 23 \\
\hline 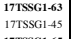 & $\begin{array}{l}782 \\
516 \\
516\end{array}$ & $\begin{array}{l}315 \\
235 \\
235\end{array}$ & 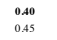 & 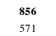 & 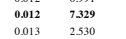 & 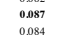 & 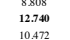 & 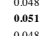 & $\begin{array}{l}\frac{3371}{10.421} \\
0.41\end{array}$ & 整. & 79.5 & s.8 & $\begin{array}{l}8 \\
803 \\
843\end{array}$ & $\begin{array}{l}6.83 \\
10.3 \\
03\end{array}$ & $\begin{array}{l}1725 \\
2225 \\
223\end{array}$ & 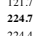 & $\begin{array}{l}16 \\
5.7 \\
1.7\end{array}$ & 列 & & 35 \\
\hline & $\begin{array}{l}1222 \\
445 \\
450\end{array}$ & $\begin{array}{l}313 \\
313\end{array}$ & $\begin{array}{l}0.21 \\
0,70\end{array}$ & 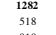 & $\begin{array}{l}0.013 \\
0.013 \\
0.013\end{array}$ & 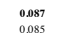 & 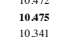 & 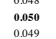 & 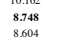 & $\begin{array}{l}\text { of } \\
\text { of } \\
0.5\end{array}$ & $\begin{array}{l}\text { sit } \\
\text { silu } \\
\text { sit }\end{array}$ & $\begin{array}{l}2.6 \\
46 \\
46\end{array}$ & 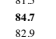 & $\begin{array}{l}8.5 \\
885 \\
8_{22}\end{array}$ & 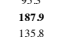 & 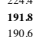 & 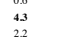 & 然 & $\begin{array}{l}\text { s.1. } \\
\text { s.1.1. } \\
\text { s.t. }\end{array}$ & 等 \\
\hline 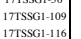 & 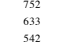 & $\begin{array}{l}233 \\
239 \\
230\end{array}$ & $\begin{array}{l}0.038 \\
\text { os } \\
\text { ses }\end{array}$ & 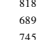 & 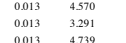 & $\begin{array}{l}\text { ous } \\
\text { ous } \\
\text { ons }\end{array}$ & 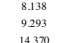 & 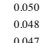 & 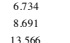 & $\begin{array}{l}0.05 \\
0.07 \\
0.3\end{array}$ & $\begin{array}{l}8.1 \\
8322 \\
832\end{array}$ & $\begin{array}{l}37 \\
27 \\
3.0\end{array}$ & 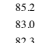 & 尊, & 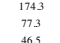 & $\begin{array}{l}1,1009 \\
1994 \\
1904\end{array}$ & $\begin{array}{l}3.7 \\
0.22 \\
0.2\end{array}$ & $\begin{array}{l}0.5 \\
0.0 \\
0.0\end{array}$ & $\begin{array}{l}821 \\
8322\end{array}$ & $\begin{array}{l}3.7 \\
2.7 \\
2.7\end{array}$ \\
\hline 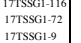 & 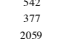 & 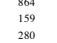 & 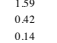 & 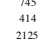 & 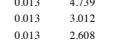 & 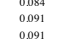 & 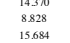 & 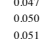 & 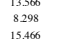 & $\begin{array}{l}0.1 \\
0.1 \\
0.1\end{array}$ & 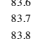 & $\begin{array}{l}35 \\
25 \\
22 \\
22\end{array}$ & 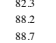 & 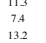 & $\begin{array}{l}203 \\
2102 \\
21213 \\
213\end{array}$ & 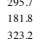 & $\begin{array}{l}\text { s. } \\
\text { so } \\
5,5\end{array}$ & $\begin{array}{l}01 \\
0.6 \\
0.4\end{array}$ & 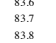 & $\begin{array}{l}39 \\
25 \\
25 \\
22\end{array}$ \\
\hline 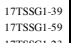 & 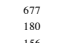 & 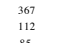 & $\begin{array}{l}0.54 \\
0.62 \\
0.52\end{array}$ & $\begin{array}{l}763 \\
207 \\
207\end{array}$ & 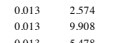 & 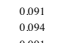 & 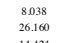 & $\begin{array}{l}0.0950 \\
00551 \\
0.51\end{array}$ & 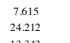 & $\begin{array}{l}0.2 \\
0.12\end{array}$ & 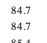 & $\begin{array}{l}22 \\
83 \\
83\end{array}$ & 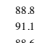 & $\begin{array}{l}68 \\
225 \\
225\end{array}$ & $\begin{array}{l}2007 \\
2012 \\
2012\end{array}$ & $\begin{array}{l}1678 \\
4775 \\
4725\end{array}$ & 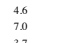 & $\begin{array}{l}0.6 \\
03 \\
03\end{array}$ & $\begin{array}{l}847 \\
847 \\
847\end{array}$ & $\begin{array}{l}22 \\
83 \\
83\end{array}$ \\
\hline & $\infty$ & $\begin{array}{c}36 \\
36 \\
59\end{array}$ & $\begin{array}{l}0.60 \\
0.600 \\
0.200\end{array}$ & $\begin{array}{l}60 \\
0.08 \\
308\end{array}$ & 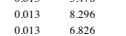 & 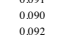 & 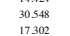 & 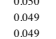 & 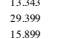 & $\begin{array}{l}0.1 \\
0.1 \\
0.3\end{array}$ & $\begin{array}{l}8.87 \\
860 \\
864\end{array}$ & 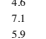 & 88.6 & $\begin{array}{l}223 \\
223 \\
174\end{array}$ & $\begin{array}{l}1725 \\
165 \\
1610\end{array}$ & 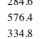 & $\begin{array}{l}3.7 \\
15 \\
30\end{array}$ & . & 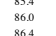 & 势: \\
\hline 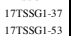 & $\begin{array}{l}461 \\
467 \\
467\end{array}$ & 1.188 & $\begin{array}{l}0.30 \\
0.48 \\
0.48\end{array}$ & 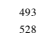 & $\begin{array}{ll}0.014 \\
0.014\end{array}$ & 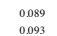 & $\begin{array}{l}7.1828 \\
1.1378\end{array}$ & 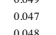 & 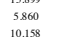 & $\begin{array}{l}0.5 \\
0.4\end{array}$ & 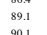 & 3.7 & $\begin{array}{l}870 \\
8700 \\
0.02\end{array}$ & 80 & 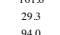 & 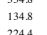 & 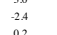 & $\begin{array}{l}0.4 \\
0.40 \\
0.04\end{array}$ & $\begin{array}{ll}8 \\
801 \\
8012\end{array}$ & $\begin{array}{l}59 \\
3.7 \\
36\end{array}$ \\
\hline 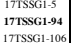 & 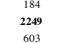 & $\begin{array}{l}506 \\
500 \\
200 \\
200\end{array}$ & $\begin{array}{l}0.23 \\
0.22 \\
0.48\end{array}$ & 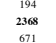 & 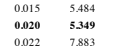 & 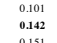 & 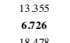 & 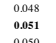 & 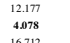 & $\begin{array}{l}0.8 \\
0.8 \\
0.8\end{array}$ & $\begin{array}{l}9292 \\
1299 \\
1299\end{array}$ & 6.9. & 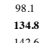 & $\begin{array}{l}12.4 \\
8.5 \\
8.5\end{array}$ & 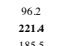 & 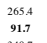 & $\begin{array}{l}0.1 \\
3.6 \\
3.6\end{array}$ & $\begin{array}{l}0.0 \\
0.0 \\
0.0\end{array}$ & $\begin{array}{l}9827 \\
1999 \\
1929\end{array}$ & $\begin{array}{c}53 \\
69 \\
69 \\
9\end{array}$ \\
\hline 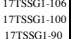 & $\begin{array}{ll}6.013 \\
122 \\
763\end{array}$ & $\begin{array}{l}240 \\
208 \\
\end{array}$ & 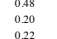 & 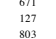 & 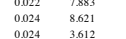 & $\begin{array}{l}0.167 \\
0.167 \\
0.167\end{array}$ & 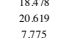 & 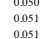 & 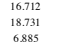 & $\begin{array}{l}0.04 \\
0.3 \\
0.4\end{array}$ & 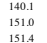 & $\begin{array}{l}1,199 \\
129 \\
5.4\end{array}$ & 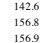 & $\begin{array}{l}2.23 \\
20,5 \\
112\end{array}$ & 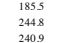 & 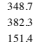 & $\begin{array}{l}18 \\
3.7 \\
3.5\end{array}$ & $\begin{array}{ll}0.1 \\
0.2 \\
0.5\end{array}$ & 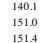 & $\begin{array}{l}109 \\
129 \\
\text { s. }\end{array}$ \\
\hline 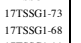 & $\begin{array}{l}160 \\
307 \\
307\end{array}$ & $\begin{array}{l}239 \\
197 \\
107\end{array}$ & $\begin{array}{l}154 \\
1.44 \\
104\end{array}$ & 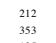 & 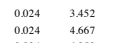 & $\begin{array}{l}0.162 \\
0.1720 \\
0.020\end{array}$ & 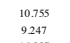 & $\begin{array}{l}\text { ons } \\
\text { oass } \\
\text { oss }\end{array}$ & $\begin{array}{l}10198 \\
1083 \\
7983\end{array}$ & $\begin{array}{l}0.0 \\
04\end{array}$ & $\begin{array}{l}1520 \\
15232 \\
1523\end{array}$ & $\begin{array}{l}52 \\
70 \\
70\end{array}$ & 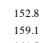 & $\begin{array}{l}151 \\
1.35 \\
135\end{array}$ & $\begin{array}{l}1068 \\
2620 \\
2020\end{array}$ & 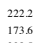 & $\begin{array}{l}0.5 \\
43 \\
43\end{array}$ & $\begin{array}{l}\text { o. } \\
\text { o. } \\
\text { of }\end{array}$ & $\begin{array}{l}1522 \\
1252 \\
1232\end{array}$ & $\frac{52}{10}$ \\
\hline 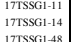 & 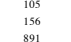 & $\begin{array}{l}85 \\
110 \\
100 \\
102\end{array}$ & $\begin{array}{l}0.081 \\
0.70 \\
\text { ond }\end{array}$ & $\begin{array}{l}125 \\
181 \\
1212\end{array}$ & $\begin{array}{l}0.024 \\
0.024 \\
0.025\end{array}$ & 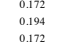 & 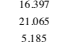 & 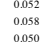 & 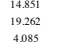 & $\begin{array}{l}0.4 \\
0.4 \\
0.5\end{array}$ & 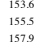 & 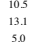 & 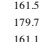 & $\begin{array}{l}2.242 \\
3.42 \\
37\end{array}$ & 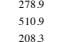 & 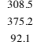 & $\begin{array}{l}495 \\
135 \\
20\end{array}$ & $\begin{array}{l}0.7 \\
0.7 \\
0.4\end{array}$ & 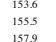 & 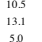 \\
\hline 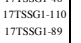 & $\begin{array}{l}274 \\
103 \\
12\end{array}$ & 167. & $\begin{array}{l}0.91 \\
0.97\end{array}$ & $\begin{array}{l}313 \\
132 \\
123\end{array}$ & $\begin{array}{ll}0.025 \\
0.025 \\
0.025 & 3488 \\
8.958\end{array}$ & $\begin{array}{l}0.165 \\
0.193 \\
0.193\end{array}$ & 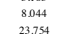 & $\begin{array}{l}\text { ous } \\
\text { ouss } \\
\text { ousc }\end{array}$ & 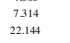 & 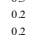 & 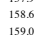 & $\begin{array}{l}52 \\
5135 \\
135\end{array}$ & 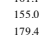 & $\begin{array}{l}115 \\
1383 \\
353\end{array}$ & 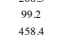 & 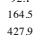 & 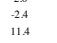 & $\begin{array}{l}0.5 \\
0.5 \\
0.5\end{array}$ & 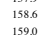 & 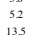 \\
\hline 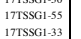 & 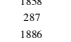 & $\begin{array}{l}105 \\
258 \\
216 \\
210\end{array}$ & 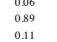 & $\begin{array}{l}1287 \\
347 \\
1496\end{array}$ & 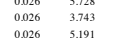 & 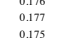 & $\begin{array}{ll}8.231 \\
12321 \\
69333\end{array}$ & 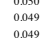 & 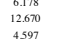 & $\begin{array}{l}0.2 \\
0.7 \\
0.7\end{array}$ & $\begin{array}{l}1683 \\
1653 \\
\text { 1659 }\end{array}$ & $\begin{array}{l}9.1 \\
601 \\
85\end{array}$ & 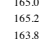 & $\begin{array}{l}1 \\
1099 \\
104\end{array}$ & $\begin{array}{l}127 \\
1467 \\
136\end{array}$ & 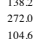 & 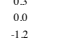 & 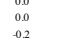 & $\begin{array}{l}104 \\
165 \\
\text { 165. }\end{array}$ & $\begin{array}{ll}93 \\
601 \\
85\end{array}$ \\
\hline & $\underset{\substack{19 \\
73}}{2}$ & $\begin{array}{l}699 \\
{ }_{580}^{6}\end{array}$ & $\begin{array}{l}0.76 \\
0.78 \\
0.85\end{array}$ & 然7 & $\begin{array}{ll}0.026 \\
0.2026\end{array}$ & $\begin{array}{l}0.179 \\
0.173 \\
0.77\end{array}$ & $\begin{array}{l}22,992 \\
5.9966\end{array}$ & $\begin{array}{l}0.000 \\
\text { ons }\end{array}$ & $\begin{array}{l}21.198 \\
4.684 \\
4\end{array}$ & 整 & 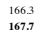 & $\begin{array}{l}12.4 \\
.0 .0\end{array}$ & & $\begin{array}{l}342 \\
8.8 \\
8.8\end{array}$ & 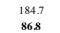 & $\begin{array}{l}4006 \\
\text { sing }\end{array}$ & $\begin{array}{l}.0 .7 \\
.0 .2\end{array}$ & & $\begin{array}{l}166 \\
160\end{array}$ & 124 \\
\hline 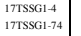 & $\begin{array}{l}4329 \\
{ }_{232}\end{array}$ & $\begin{array}{l}314 \\
322 \\
32\end{array}$ & $\begin{array}{l}0,738 \\
139 \\
139\end{array}$ & $\begin{array}{l}503 \\
307\end{array}$ & $\begin{array}{ll}0.027 \\
0.027\end{array}$ & $\begin{array}{l}0.1877 \\
0.223\end{array}$ & $\begin{array}{l}9.177 \\
1.5688\end{array}$ & $\begin{array}{l}\text { osis } \\
\text { oass }\end{array}$ & 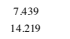 & $\begin{array}{l}0.5 \\
0.4\end{array}$ & $\begin{array}{l}168.7 \\
108.8 \\
170 .\end{array}$ & 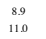 & 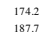 & $\begin{array}{l}1466 \\
20.5\end{array}$ & 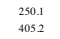 & $\begin{array}{l}1.227 \\
12033\end{array}$ & $\begin{array}{l}32 \\
9.2 \\
90\end{array}$ & $\begin{array}{l}0.4 \\
0.6\end{array}$ & $\begin{array}{l}\frac{1687}{107} \\
170.8\end{array}$ & 89.9 \\
\hline 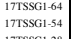 & $\begin{array}{l}288 \\
349 \\
349\end{array}$ & $\begin{array}{l}\text { 年 } \\
363\end{array}$ & $\begin{array}{l}0.63 \\
\text { ias }\end{array}$ & $\begin{array}{l}261 \\
4344 \\
434\end{array}$ & $\begin{array}{l}0.027 \\
0.027 \\
0.23659\end{array}$ & $\begin{array}{l}0.1778 \\
0.180 \\
0.180\end{array}$ & 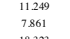 & 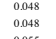 & $\begin{array}{l}1.06868 \\
6947\end{array}$ & $\begin{array}{l}0.2 \\
0.4\end{array}$ & 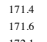 & $\begin{array}{l}74 \\
62 \\
62\end{array}$ & $\begin{array}{l}1.588 \\
\text { lis8 }\end{array}$ & $\begin{array}{l}1.7 .1 \\
12.1 \\
2.1\end{array}$ & 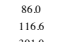 & $\begin{array}{l}2156,1 \\
156,1\end{array}$ & $\begin{array}{l}.34 \\
.22\end{array}$ & 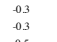 & 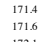 & $\begin{array}{l}7.4 \\
6.2\end{array}$ \\
\hline & in & & 0.67 & 128 & $\begin{array}{l}0.027 \\
0.0483 \\
7.0787\end{array}$ & 0.182 & 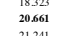 & 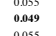 & 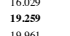 & 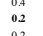 & $\begin{array}{l}1212 \\
1224 \\
120\end{array}$ & 12127 & $\begin{array}{l}17878 \\
1698 \\
1092\end{array}$ & $\begin{array}{l}3.98 \\
31.8\end{array}$ & $\begin{array}{l}39.4 .13 \\
135.4\end{array}$ & $\begin{array}{l}3929 \\
399 \\
390\end{array}$ & & & 1072 & 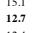 \\
\hline 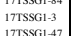 & $\begin{array}{l}1356 \\
3.675\end{array}$ & $\begin{array}{ll}821 \\
121 \\
4800\end{array}$ & 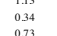 & $\begin{array}{l}\frac{384}{384} \\
770 \\
770\end{array}$ & 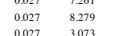 & 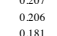 & 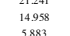 & $\begin{array}{l}\text { ouss } \\
\text { ouss } \\
\text { ous }\end{array}$ & 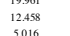 & 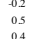 & 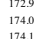 & 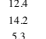 & 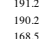 & 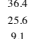 & 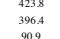 & 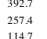 & $\begin{array}{l}96 \\
8.5 \\
3.3\end{array}$ & $\begin{array}{l}0.05 \\
0.6 \\
0.6\end{array}$ & 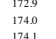 & 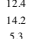 \\
\hline 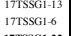 & $\begin{array}{l}226 \\
63 \\
63\end{array}$ & $\begin{array}{l}133 \\
65 \\
65\end{array}$ & $\begin{array}{l}0.59 \\
1.04\end{array}$ & $\begin{array}{l}257 \\
78 \\
78\end{array}$ & $\begin{array}{l}0.027 \\
0.028\end{array}$ & $\begin{array}{l}0.197 \\
02222 \\
0.27\end{array}$ & 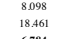 & $\begin{array}{l}0.050 \\
\text { o.sis }\end{array}$ & $\begin{array}{l}7.5399 \\
17517\end{array}$ & $\begin{array}{l}0.2 \\
0.2\end{array}$ & $\begin{array}{l}1745 \\
1764 .\end{array}$ & 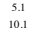 & 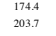 & $\begin{array}{l}1329 \\
1335\end{array}$ & $\begin{array}{l}1730.9 \\
533.7\end{array}$ & $\begin{array}{l}1.167 .1 \\
3434\end{array}$ & $\begin{array}{l}0.1 \\
13.4 \\
13.4\end{array}$ & $\begin{array}{l}0.08 \\
0.8\end{array}$ & 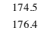 & $\begin{array}{l}5.1 \\
\text { sil. } \\
10.1\end{array}$ \\
\hline 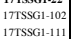 & $\begin{array}{l}307 \\
307 \\
544\end{array}$ & $\begin{array}{c}201 \\
201 \\
498\end{array}$ & $\begin{array}{l}0.65 \\
0.09 \\
0.01\end{array}$ & $\begin{array}{l}355 \\
351 \\
601\end{array}$ & $\begin{array}{lll}0.02828 \\
0.028\end{array}$ & 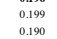 & $\begin{array}{l}8.980 \\
5880 \\
5810\end{array}$ & 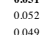 & $\begin{array}{l}8.026 \\
8276 \\
4276\end{array}$ & 年 & 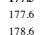 & 67 & 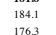 & $\begin{array}{l}148 \\
148 \\
044\end{array}$ & 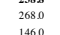 & 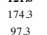 & $\begin{array}{l}24 \\
35 \\
3.13\end{array}$ & 0.4 & 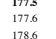 & $\begin{array}{l}7.7 \\
6.7 \\
60\end{array}$ \\
\hline 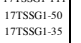 & 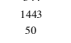 & $\begin{array}{l}580 \\
27 \\
27\end{array}$ & 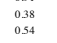 & $\begin{array}{l}\operatorname{lis}_{56} \\
56\end{array}$ & 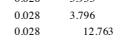 & 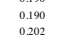 & 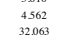 & $\begin{array}{l}\text { ous } \\
\text { ous } \\
\text { ons }\end{array}$ & $\begin{array}{l}2529 \\
25413 \\
20413\end{array}$ & $\begin{array}{l}08 \\
03 \\
03\end{array}$ & 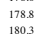 & 67 & 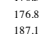 & 勇: & 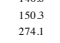 & 5625 & $\begin{array}{l}-11 \\
-16 \\
36\end{array}$ & 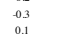 & 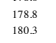 & 226 \\
\hline & 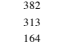 & 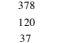 & $\begin{array}{ll}0.099 \\
\text { os } \\
\text { ond }\end{array}$ & 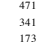 & 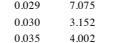 & 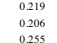 & 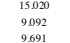 & 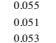 & 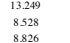 & 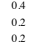 & 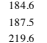 & 12.9 & 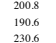 & 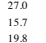 & $\begin{array}{l}3.395 \\
2294 \\
2.44\end{array}$ & 272.5 & $\begin{array}{ll}81 \\
16 \\
48\end{array}$ & $\begin{array}{l}0.8 \\
0.62 \\
0.6\end{array}$ & & 12.9 \\
\hline 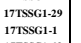 & $\begin{array}{l}3736 \\
331\end{array}$ & 密9 & $\begin{array}{l}0.02 \\
0.000\end{array}$ & $\begin{array}{l}\frac{3810}{384} \\
434\end{array}$ & $\begin{array}{l}0.035 \\
0.0356 \\
0.036\end{array}$ & 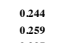 & 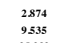 & $\begin{array}{l}\text { ofosi } \\
\text { ous }\end{array}$ & 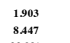 & 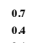 & 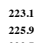 & $\begin{array}{l}4,7 \\
9,8 \\
9,8\end{array}$ & 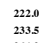 & $\begin{array}{l}5,87 \\
5197\end{array}$ & $\begin{array}{l}21122 \\
3103 \\
303\end{array}$ & $\begin{array}{l}435 \\
1817 \\
1817\end{array}$ & 然 & 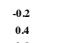 & 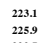 & , 9.7 \\
\hline & 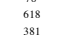 & 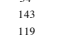 & 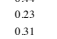 & $\begin{array}{l}652 \\
692 \\
409\end{array}$ & 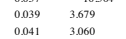 & 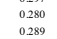 & 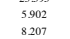 & 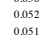 & 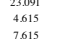 & 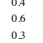 & 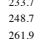 & 90 & 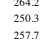 & $\begin{array}{l}5174 \\
1130 \\
185\end{array}$ & 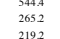 & 1. 1027 & $\begin{array}{l}106 \\
0.6 \\
.16\end{array}$ & & 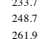 & 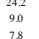 \\
\hline 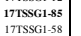 & 128 & & & & & & & & $\begin{array}{l}7.76 \\
703\end{array}$ & & & & & $\begin{array}{l}261 \\
2018 \\
208\end{array}$ & & & & & & \\
\hline
\end{tabular}




\begin{tabular}{|c|c|c|c|c|c|c|c|c|c|c|c|c|c|c|c|c|c|c|c|c|c|}
\hline 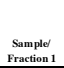 & (promer) & 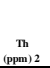 & 勇 & 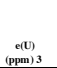 & 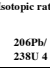 & & $\begin{aligned} 202 p \mathrm{w} \\
2 \\
255 \mathrm{U}\end{aligned}$ & & 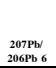 & & & 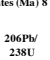 & $\begin{array}{l}\text { that } \\
\text { athe }\end{array}$ & 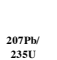 & 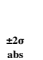 & 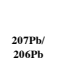 & 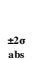 & & 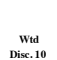 & 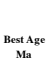 & 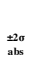 \\
\hline$\pi$ & $\begin{array}{l}1311 \\
310 \\
310\end{array}$ & & & $\begin{array}{l}1.186 \\
3.99\end{array}$ & & & & & & & 0.8 & & & & 327 & & & & & & \\
\hline 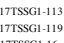 & 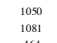 & $\begin{array}{l}202 \\
1118 \\
118\end{array}$ & $\begin{array}{l}0.19 \\
0.11\end{array}$ & 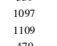 & & & $\begin{array}{l}2,2616 \\
2,913\end{array}$ & $\begin{array}{l}\text { s.2312 } \\
\text { s.186 }\end{array}$ & $\begin{array}{l}\text { oos8 } \\
0.908\end{array}$ & 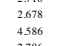 & $\begin{array}{l}0.9 \\
0.8\end{array}$ & 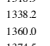 & 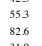 & 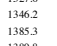 & 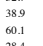 & 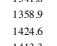 & $\begin{array}{l}5,808 \\
s, 11\end{array}$ & $\begin{array}{l}1,5 \\
4,5\end{array}$ & $\begin{array}{l}\text { of } \\
\text { o. }\end{array}$ & 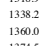 & 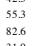 \\
\hline 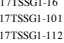 & 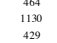 & 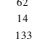 & 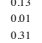 & 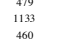 & & $\begin{array}{l}62808 \\
20856\end{array}$ & 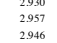 & 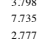 & 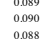 & 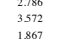 & $\begin{array}{l}89 \\
097 \\
07\end{array}$ & 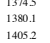 & 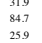 & 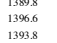 & 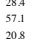 & 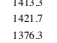 & 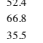 & $\begin{array}{l}210 \\
2.20\end{array}$ & $\begin{array}{l}0.5 \\
.0 .5 \\
-1.1\end{array}$ & 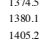 & 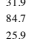 \\
\hline & & 224 & $\begin{array}{l}0.46 \\
0.23\end{array}$ & $\begin{array}{l}5366 \\
5127\end{array}$ & & & 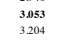 & $\begin{array}{l}3567 \\
0.455\end{array}$ & $\begin{array}{l}0.0909 \\
\text { o.9093 }\end{array}$ & $\begin{array}{l}2.5279 \\
4,499\end{array}$ & $\begin{array}{l}0.7 \\
0.9\end{array}$ & $\begin{array}{l}142424 \\
1.2429\end{array}$ & $\begin{array}{l}321 \\
3200 \\
1060\end{array}$ & $\begin{array}{l}142121 \\
1.452\end{array}$ & 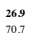 & $\begin{array}{l}141465 \\
1.452\end{array}$ & 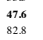 & $\begin{array}{l}.06 \\
.0 .6 \\
42\end{array}$ & $\begin{array}{l}-.03 \\
.03\end{array}$ & $\begin{array}{l}14242 \\
1.2329\end{array}$ & $\begin{array}{l}32.1 \\
1060\end{array}$ \\
\hline 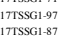 & 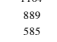 & $\begin{array}{l}461 \\
3854\end{array}$ & $\begin{array}{l}0.52 \\
0.52\end{array}$ & 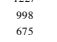 & & $\begin{array}{c}30191 \\
3.148 \\
3\end{array}$ & 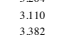 & 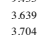 & 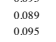 & $\begin{array}{l}20393 \\
19951\end{array}$ & $\begin{array}{l}\text { os } \\
\text { os }\end{array}$ & 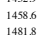 & $\begin{array}{l}393 \\
\text { 393 } \\
415\end{array}$ & 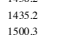 & $\begin{array}{l}2786 \\
28.6\end{array}$ & 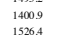 & 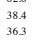 & $\begin{array}{l}41 \\
421\end{array}$ & 年 & 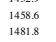 & $\begin{array}{l}3,393 \\
4.15\end{array}$ \\
\hline 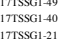 & 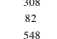 & ${ }_{45}$ & 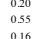 & 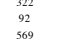 & & 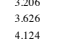 & 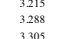 & 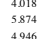 & 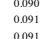 & 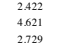 & $\begin{array}{l}08 \\
0.8 \\
0.68\end{array}$ & 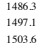 & $\begin{array}{l}\text { s24 } \\
\text { s88 } \\
\text { sis }\end{array}$ & 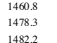 & $\begin{array}{l}3 \\
\text { sal } \\
4.77\end{array}$ & 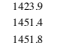 & 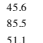 & $\begin{array}{c}44 \\
3.32 \\
3.6\end{array}$ & 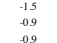 & 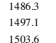 & $\begin{array}{l}424 \\
483 \\
8\end{array}$ \\
\hline & & & $\begin{array}{l}0.12 \\
0.26\end{array}$ & $\begin{array}{l}647 \\
497\end{array}$ & & $\begin{array}{l}4,599 \\
9890\end{array}$ & $\begin{array}{l}3499 \\
3,409\end{array}$ & $\begin{array}{r}5201 \\
11001\end{array}$ & $\begin{array}{l}0.044 \\
0.004\end{array}$ & $\begin{array}{l}2.2429 \\
6324\end{array}$ & $\begin{array}{l}0.9 \\
0.9 \\
0.8\end{array}$ & $\begin{array}{l}15252 \\
15252\end{array}$ & $\begin{array}{l}621 \\
1.21\end{array}$ & $\begin{array}{l}115157 \\
1\end{array}$ & $\begin{array}{l}40.1 \\
\text { to. }\end{array}$ & $\begin{array}{l}15066 \\
15348\end{array}$ & $\begin{array}{l}452 \\
1420\end{array}$ & $\begin{array}{l}-10 \\
108\end{array}$ & $\begin{array}{l}-0.3 \\
0.1\end{array}$ & $\begin{array}{l}152222 \\
1 \\
125222\end{array}$ & 62.1 \\
\hline 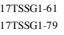 & $\begin{array}{l}368 \\
368\end{array}$ & 75 & $\begin{array}{l}020 \\
0.090 \\
0.00\end{array}$ & $\begin{array}{l}386 \\
3.85\end{array}$ & & $\begin{array}{l}53510 \\
45110\end{array}$ & $\begin{array}{l}3649 \\
3.459\end{array}$ & $\begin{array}{l}7579 \\
5,582\end{array}$ & $\begin{array}{l}\text { o.0949 } \\
\text { o.906 }\end{array}$ & $\begin{array}{l}53619 \\
3.619\end{array}$ & $\begin{array}{l}0.7 \\
0.78\end{array}$ & 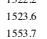 & $\begin{array}{l}122 \\
7222 \\
6020\end{array}$ & 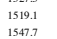 & $\begin{array}{c}580 \\
580 \\
494\end{array}$ & 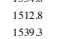 & 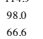 & $\begin{array}{l}0.7 \\
0.707\end{array}$ & $\begin{array}{l}0.1 \\
0.12\end{array}$ & $\begin{array}{l}1253.5 \\
1555,7\end{array}$ & $\begin{array}{l}722 \\
6220\end{array}$ \\
\hline 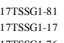 & 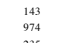 & $\begin{array}{l}13 \\
425\end{array}$ & $\begin{array}{l}\text { sog } \\
\text { o.t }\end{array}$ & $\begin{array}{l}160 \\
1074\end{array}$ & & $\begin{array}{l}46252 \\
3242\end{array}$ & $\begin{array}{l}3.668 \\
38 s 1\end{array}$ & $\begin{array}{l}6.859 \\
\text { s.729 }\end{array}$ & 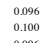 & $\begin{array}{l}4,48938 \\
1843\end{array}$ & $\begin{array}{l}07 \\
09\end{array}$ & $\begin{array}{l}1.7566 \\
1,843\end{array}$ & 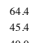 & 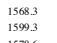 & $\begin{array}{l}513 \\
2906\end{array}$ & 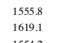 & $\begin{array}{l}8.856 \\
3359\end{array}$ & 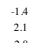 & $\begin{array}{l}\text { s. } \\
\text { o. } \\
0.8\end{array}$ & $\begin{array}{l}151767 \\
158,3\end{array}$ & $\begin{array}{l}6.45 \\
454\end{array}$ \\
\hline 7 & $\begin{array}{l}235 \\
\text { ssis } \\
\text { sis }\end{array}$ & 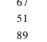 & $\begin{array}{l}\text { o. } \\
\text { o. } \\
\text { o.1 }\end{array}$ & $\begin{array}{l}217 \\
\text { ong } \\
6010\end{array}$ & & & 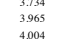 & 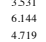 & 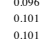 & 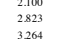 & $\begin{array}{l}\text { of } \\
\text { os } \\
0.7\end{array}$ & 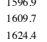 & 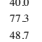 & 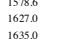 & 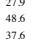 & 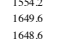 & 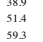 & $\begin{array}{l}28 \\
2.2 \\
15\end{array}$ & $\begin{array}{l}\text { of } \\
\text { os } \\
\text { os }\end{array}$ & 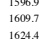 & $\begin{array}{l}77^{707} \\
478\end{array}$ \\
\hline & & & & & & & 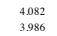 & $\begin{array}{l}4.432 \\
4.497\end{array}$ & & $\begin{array}{l}2.444 \\
53303\end{array}$ & $\begin{array}{l}0.8 \\
0.8\end{array}$ & $\begin{array}{l}162121 \\
10245\end{array}$ & $\begin{array}{l}5.1 \\
2.09\end{array}$ & 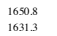 & $\begin{array}{l}345 \\
435.7\end{array}$ & $\begin{array}{l}16747 \\
1 \\
127272\end{array}$ & $\begin{array}{l}4.45 \\
4.55\end{array}$ & $\begin{array}{l}25 \\
\text { 2. }\end{array}$ & $\begin{array}{l}0.8 \\
0.3\end{array}$ & $\begin{array}{l}1.62 .21 \\
10345\end{array}$ & $\begin{array}{l}5.1 .1 \\
20.9\end{array}$ \\
\hline 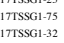 & $\begin{array}{l}\text { sit } \\
\text { sites }\end{array}$ & ${ }_{20}^{29}$ & $\begin{array}{l}\text { ous } \\
0.02 \\
0.07\end{array}$ & 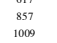 & & $\begin{array}{c}3.328 \\
5,5 s 5\end{array}$ & 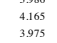 & 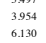 & 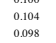 & $\begin{array}{l}2.1368 \\
2.593\end{array}$ & 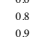 & 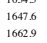 & 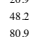 & 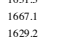 & $\begin{array}{l}319 \\
3196\end{array}$ & 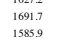 & $\begin{array}{l}380 \\
3898 \\
477\end{array}$ & $\begin{array}{l}26 \\
26 \\
49\end{array}$ & $\begin{array}{l}\text { of } \\
\text { o. }\end{array}$ & 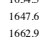 & $\begin{array}{l}882 \\
8802\end{array}$ \\
\hline 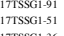 & 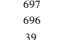 & 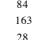 & $\begin{array}{l}0.12 \\
0.25 \\
0725\end{array}$ & 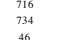 & & 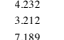 & 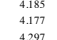 & 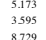 & $\begin{array}{l}0.103 \\
0.101\end{array}$ & 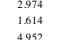 & $\begin{array}{l}0.8 \\
0.9\end{array}$ & 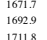 & 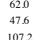 & 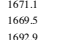 & $\begin{array}{l}4.45 \\
2990\end{array}$ & 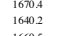 & $\begin{array}{l}5.909 \\
2907\end{array}$ & 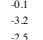 & $\begin{array}{l}\text { o. } \\
\text { - } \\
\text { s. }\end{array}$ & 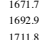 & $\begin{array}{l}620 \\
4776\end{array}$ \\
\hline 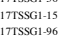 & $\begin{array}{l}373 \\
2375\end{array}$ & $\begin{array}{l}102 \\
752\end{array}$ & $\begin{array}{l}0.27 \\
0.27 \\
0.25\end{array}$ & $\begin{array}{l}397 \\
3.13\end{array}$ & & & $\begin{array}{l}4,278 \\
4 \\
4\end{array}$ & $\begin{array}{l}3.183 \\
4.253\end{array}$ & $\begin{array}{l}0.1020 \\
0.106\end{array}$ & $\begin{array}{l}2.1116 \\
3893\end{array}$ & $\begin{array}{l}0.7 \\
0.5\end{array}$ & 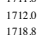 & $\begin{array}{l}357 \\
3.77\end{array}$ & $\begin{array}{l}1.68922 \\
1.7279\end{array}$ & $\begin{array}{l}259 \\
3.676\end{array}$ & $\begin{array}{l}16009 \\
1732\end{array}$ & $\begin{array}{l}387 \\
387\end{array}$ & $\begin{array}{l}.3 .1 \\
0.8\end{array}$ & $\begin{array}{l}-1.4 \\
0.4\end{array}$ & $\begin{array}{l}1712121 \\
117188\end{array}$ & $\begin{array}{l}3577 \\
3.77\end{array}$ \\
\hline 7 & $\begin{array}{l}147 \\
837\end{array}$ & $\begin{array}{l}49 \\
52\end{array}$ & $\begin{array}{l}0.34 \\
0.64\end{array}$ & 1189 & & $\begin{array}{l}2.671 \\
2.741\end{array}$ & 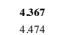 & $\begin{array}{l}34288 \\
3308\end{array}$ & $\begin{array}{l}0.104 \\
0.106\end{array}$ & $\begin{array}{l}2.1498 \\
2.063\end{array}$ & $\begin{array}{l}0.7 \\
0.7 \\
0.7\end{array}$ & 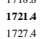 & 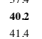 & 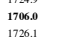 & 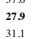 & 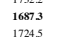 & 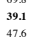 & $\begin{array}{l}-20 \\
-20 \\
-02\end{array}$ & 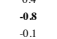 & 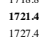 & 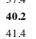 \\
\hline 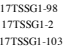 & 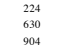 & 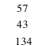 & $\begin{array}{l}0.25 \\
\text { oog } \\
\text { oil }\end{array}$ & 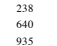 & 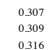 & $\begin{array}{l}3.356 \\
39250 \\
2,8989\end{array}$ & 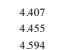 & 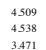 & $\begin{array}{l}0.1040 \\
0.105 \\
0.105\end{array}$ & $\begin{array}{l}2.777 \\
2.287 \\
1981\end{array}$ & $\begin{array}{l}0.8 \\
0.8 \\
0.9 \\
0.8\end{array}$ & 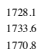 & $\begin{array}{l}537.7 \\
5533 \\
474\end{array}$ & $\begin{array}{l}171736 \\
1.726 \\
1.742\end{array}$ & $\begin{array}{l}366 \\
3.60 \\
3.785\end{array}$ & 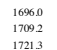 & $\begin{array}{l}502 \\
4015 \\
4.15\end{array}$ & $\begin{array}{l}-19 \\
-1.4 \\
-1.9\end{array}$ & $\begin{array}{l}-0.6 \\
-0.04 \\
-0.4\end{array}$ & 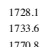 & 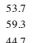 \\
\hline & & & 0.62 & $\frac{133}{691}$ & & 4091 & $\frac{4460}{0.976}$ & & $\frac{0.106}{0.948}$ & $\frac{3.185}{8826}$ & & 17822 & $\frac{662}{3.0}$ & $\frac{17685}{748}$ & 7.0 & $\frac{172491}{119.1}$ & $\frac{574}{1958}$ & & & $\frac{1783.4}{73.4}$ & \\
\hline 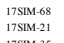 & $\begin{array}{l}1,763 \\
4,55\end{array}$ & $\begin{array}{l}{ }_{529}^{29} \\
{ }^{2}\end{array}$ & $\begin{array}{l}0.24 \\
1.17\end{array}$ & $\begin{array}{l}18645 \\
5,55\end{array}$ & & & $\begin{array}{l}0.075 \\
0.080 \\
0.080\end{array}$ & $\begin{array}{c}5.284 \\
98587\end{array}$ & $\begin{array}{l}\text { oost } \\
\text { oats }\end{array}$ & $\begin{array}{l}4611 \\
9.151\end{array}$ & 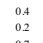 & $\begin{array}{l}744 \\
76,3\end{array}$ & $\begin{array}{l}198 \\
28\end{array}$ & $\begin{array}{l}735.5 \\
785\end{array}$ & $\begin{array}{l}37 \\
{ }_{74}\end{array}$ & $\begin{array}{l}21263 \\
1453\end{array}$ & $\begin{array}{l}1067 ? \\
2017\end{array}$ & $\begin{array}{l}-13 \\
28\end{array}$ & $\begin{array}{l}-9.3 \\
0.3\end{array}$ & 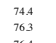 & $\begin{array}{l}19 \\
28\end{array}$ \\
\hline 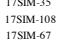 & 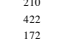 & $\begin{array}{l}100 \\
270 \\
148\end{array}$ & $\begin{array}{l}\text { os } \\
\text { ost } \\
\text { osto }\end{array}$ & 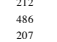 & & 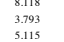 & 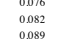 & 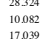 & 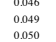 & 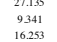 & $\begin{array}{l}0.7 \\
0.27 \\
0.1\end{array}$ & 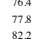 & $\begin{array}{l}62 \\
29 \\
42\end{array}$ & 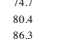 & $\begin{array}{l}202 \\
78 \\
180\end{array}$ & $\begin{array}{l}17273 \\
15202\end{array}$ & 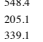 & $\begin{array}{l}2.2 \\
32 \\
48\end{array}$ & $\begin{array}{l}0.1 \\
0.1 \\
03\end{array}$ & $\begin{array}{l}7.8 \\
778 \\
872\end{array}$ & 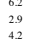 \\
\hline 17smM & $\begin{array}{l}2661 \\
\text { ais } \\
\text { ats }\end{array}$ & $\begin{array}{l}263 \\
147\end{array}$ & $\begin{array}{l}0.10 \\
0.23\end{array}$ & $\begin{array}{l}2062 \\
6190\end{array}$ & & $\begin{array}{l}2.2949 \\
6094\end{array}$ & 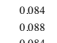 & $\begin{array}{l}80284 \\
12818\end{array}$ & $\begin{array}{l}\text { oogt7 } \\
\text { oat9 }\end{array}$ & 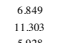 & $\begin{array}{l}0.5 \\
0.2\end{array}$ & $\begin{array}{l}822 \\
8228\end{array}$ & 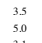 & $\begin{array}{l}8,9 \\
\text { sis }\end{array}$ & $\begin{array}{l}6.63 \\
105\end{array}$ & $\begin{array}{l}773.3 \\
1091\end{array}$ & $\begin{array}{l}1.552 \\
2.446\end{array}$ & 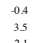 & 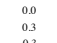 & $\begin{array}{l}822 \\
8282 \\
882\end{array}$ & $\begin{array}{l}3.5 \\
500\end{array}$ \\
\hline 1) & $\begin{array}{l}300 \\
3090 \\
1095\end{array}$ & $\begin{array}{l}192 \\
152 \\
5102\end{array}$ & $\begin{array}{l}\text { osi } \\
\text { os } \\
\text { ond }\end{array}$ & 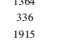 & & 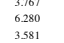 & 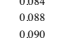 & 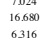 & 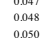 & 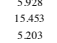 & $\begin{array}{l}02 \\
02 \\
0.5\end{array}$ & 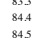 & $\begin{array}{l}53 \\
53 \\
30\end{array}$ & 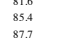 & $\begin{array}{l}136 \\
136\end{array}$ & 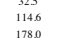 & 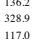 & $\begin{array}{l}21 \\
12 \\
37\end{array}$ & $\begin{array}{l}0.1 \\
0.1 \\
0.6\end{array}$ & 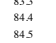 & 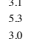 \\
\hline & & $\begin{array}{l}79 \\
1997\end{array}$ & $\begin{array}{l}0.07 \\
0.29\end{array}$ & $\begin{array}{l}1157 \\
{ }_{116}\end{array}$ & & & 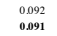 & $\begin{array}{l}68848 \\
1110606\end{array}$ & $\begin{array}{l}0.050 \\
0.550\end{array}$ & $\begin{array}{l}5.500083 \\
10.683\end{array}$ & $\begin{array}{l}0.6 \\
0.0 .1\end{array}$ & $\begin{array}{l}850 \\
s=1\end{array}$ & $\begin{array}{l}{ }_{4}^{40} \\
38\end{array}$ & $\begin{array}{l}8.83 \\
883,3\end{array}$ & $\begin{array}{c}5_{98}^{9} \\
{ }_{98}\end{array}$ & $\begin{array}{l}2029.9 \\
1334\end{array}$ & $\begin{array}{l}12120 \\
23199\end{array}$ & $\begin{array}{l}48 \\
{ }_{35}\end{array}$ & $\begin{array}{l}0.7 \\
0.7\end{array}$ & $\begin{array}{l}850 \\
8: 1\end{array}$ & $\begin{array}{l}40 \\
38\end{array}$ \\
\hline 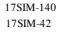 & $\begin{array}{l}8088 \\
1002\end{array}$ & $\begin{array}{l}448 \\
152\end{array}$ & $\begin{array}{l}\begin{array}{l}0.50 \\
0.15\end{array} \\
0.0\end{array}$ & $\begin{array}{l}914 \\
1037 \\
103\end{array}$ & & $\begin{array}{l}4_{3,774} \\
3\end{array}$ & 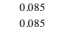 & $\begin{array}{l}12.170 \\
7,754\end{array}$ & $\begin{array}{l}0.0 .966 \\
0.046\end{array}$ & $\begin{array}{l}121200 \\
6.807 \\
6\end{array}$ & $\begin{array}{l}0.2 \\
0.4\end{array}$ & $\begin{array}{l}\frac{852}{85} \\
8 \leq 5\end{array}$ & $\begin{array}{l}40 \\
{ }_{32}^{4}\end{array}$ & $\begin{array}{l}8.4 \\
s_{229}\end{array}$ & $\begin{array}{l}96 \\
62\end{array}$ & $\begin{array}{l}32 \\
103\end{array}$ & $\begin{array}{l}20977 \\
15611\end{array}$ & .3.3. & $\begin{array}{l}-0.3 \\
-0.0\end{array}$ & $\begin{array}{l}852 \\
855\end{array}$ & ${ }_{32}^{40}$ \\
\hline 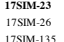 & $\begin{array}{l}461 \\
3500 \\
454\end{array}$ & 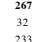 & $\begin{array}{l}\text { oss } \\
\text { os } \\
\text { os }\end{array}$ & $\begin{array}{l}524 \\
385 \\
38 \pi\end{array}$ & & 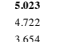 & 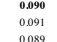 & 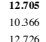 & 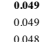 & 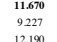 & $\begin{array}{l}0.1 \\
0.3 \\
0.1\end{array}$ & 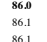 & 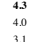 & 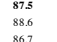 & $\begin{array}{l}10.08 \\
88 \\
15\end{array}$ & 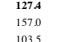 & 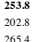 & $\begin{array}{l}1,7 \\
28 \\
07\end{array}$ & $\begin{array}{l}0.1 \\
0.1 \\
0.3\end{array}$ & $\begin{array}{l}860 \\
8060 \\
\text { sol }\end{array}$ & $\begin{array}{l}43 \\
4 \\
4\end{array}$ \\
\hline 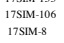 & $\begin{array}{l}409 \\
4098\end{array}$ & $\begin{array}{l}276 \\
2762\end{array}$ & $\begin{array}{l}0.59 \\
0.606\end{array}$ & $\begin{array}{l}3.44 \\
439\end{array}$ & & $\begin{array}{l}2.2555 \\
48 s 02\end{array}$ & $\begin{array}{l}0.094 \\
0.0929\end{array}$ & 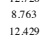 & $\begin{array}{l}\text { oosos } \\
\text { osag }\end{array}$ & $\begin{array}{l}83191 \\
1147\end{array}$ & $\begin{array}{l}00 \\
02\end{array}$ & $\begin{array}{l}870 \\
874\end{array}$ & $\begin{array}{l}{ }_{42}^{42} \\
42\end{array}$ & 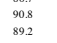 & $\begin{array}{l}76 \\
106\end{array}$ & $\begin{array}{l}19312 \\
1372\end{array}$ & 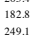 & $\begin{array}{l}42 \\
{ }_{20}^{20}\end{array}$ & $\begin{array}{l}0.5 \\
0.5\end{array}$ & $\begin{array}{l}870 \\
877\end{array}$ & $\begin{array}{l}24 \\
{ }_{24}^{4}\end{array}$ \\
\hline 1) & $\begin{array}{l}569 \\
317 \\
1717\end{array}$ & 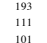 & $\begin{array}{l}\text { o34 } \\
\text { os } \\
\text { ous }\end{array}$ & 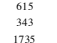 & & & 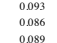 & 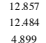 & 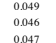 & 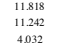 & 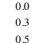 & 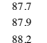 & $\begin{array}{l}44 \\
4 \\
4 \\
24\end{array}$ & 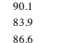 & 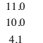 & 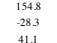 & 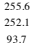 & $\begin{array}{l}27 \\
4.8 \\
-18\end{array}$ & $\begin{array}{l}02 \\
0.04 \\
0.40\end{array}$ & $\begin{array}{l}877 \\
8879 \\
889\end{array}$ & 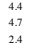 \\
\hline 1) & $\begin{array}{l}11106 \\
14160\end{array}$ & $\begin{array}{l}4.3 \\
222\end{array}$ & $\begin{array}{l}037 \\
0.370 \\
0.07\end{array}$ & 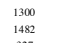 & & 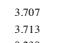 & $\begin{array}{l}0.0055 \\
0.094\end{array}$ & 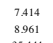 & $\begin{array}{l}\text { oolis } \\
\text { oats }\end{array}$ & $\begin{array}{l}6.42121 \\
8.155\end{array}$ & $\begin{array}{l}0.4 \\
0.5\end{array}$ & $\begin{array}{l}8088 \\
0907\end{array}$ & $\begin{array}{l}\text { 勇3 } \\
33\end{array}$ & $\begin{array}{l}917 \\
y_{14}\end{array}$ & $\begin{array}{l}65 \\
78 \\
78\end{array}$ & $\begin{array}{l}141.14 \\
1076\end{array}$ & $\begin{array}{l}1.442 \\
1821\end{array}$ & $\begin{array}{l}21 \\
07 \\
07\end{array}$ & $\begin{array}{l}0.3 \\
0.1 \\
0.1\end{array}$ & $\begin{array}{l}898 \\
0907\end{array}$ & $\begin{array}{l}33 \\
33 \\
33\end{array}$ \\
\hline 1) & 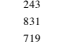 & 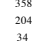 & 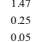 & 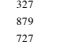 & & 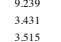 & $\begin{array}{l}0.0990 \\
0.096 \\
0.0\end{array}$ & 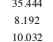 & 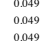 & 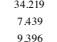 & $\begin{array}{l}0.0 \\
0.02 \\
02\end{array}$ & 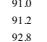 & $\begin{array}{l}8.1 \\
3.1 \\
3.2\end{array}$ & $\begin{array}{l}939 \\
\text { sis } \\
\text { s.7 }\end{array}$ & $\begin{array}{l}3.13 \\
73 \\
0,3\end{array}$ & 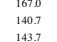 & 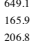 & 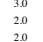 & $\begin{array}{l}0.7 \\
0.3 \\
0.3\end{array}$ & 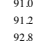 & $\begin{array}{l}8.1 \\
3.1 \\
3.2\end{array}$ \\
\hline 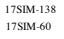 & $\begin{array}{l}\begin{array}{l}325 \\
441\end{array} \\
4\end{array}$ & $\begin{array}{l}232 \\
210\end{array}$ & $\begin{array}{l}0.72 \\
0.48\end{array}$ & $\begin{array}{l}379 \\
490 \\
490\end{array}$ & & $\begin{array}{l}1.155 \\
4.399\end{array}$ & $\begin{array}{l}0.0998 \\
0.101\end{array}$ & 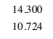 & $\begin{array}{l}0.048 \\
0.048\end{array}$ & 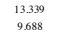 & $\begin{array}{l}01 \\
0.1 \\
0.3\end{array}$ & $\begin{array}{l}938 \\
948\end{array}$ & $\begin{array}{l}48 \\
43 \\
43\end{array}$ & $\begin{array}{l}948 \\
949\end{array}$ & $\begin{array}{l}1299 \\
1000\end{array}$ & $\begin{array}{l}120204 \\
1,444\end{array}$ & $\begin{array}{l}28744 \\
21176\end{array}$ & $\begin{array}{l}11 \\
32 \\
32\end{array}$ & $\begin{array}{l}0.1 \\
0.9 \\
0.3\end{array}$ & $\begin{array}{l}938 \\
948\end{array}$ & $\begin{array}{l}48 \\
43\end{array}$ \\
\hline & $\begin{array}{l}727 \\
3,27\end{array}$ & & $\begin{array}{l}8.09 \\
0.17\end{array}$ & 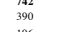 & & & $\begin{array}{l}\text { oulus } \\
\text { o.102 }\end{array}$ & 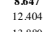 & 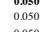 & 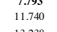 & $\begin{array}{l}0.3 \\
0.3\end{array}$ & & $\begin{array}{l}38 \\
38\end{array}$ & $\begin{array}{l}992 \\
9887\end{array}$ & $\begin{array}{l}81 \\
11.1\end{array}$ & $\begin{array}{l}2307.7 \\
1758 .\end{array}$ & $\begin{array}{l}17175 \\
2381\end{array}$ & 3.2 & $\begin{array}{l}0.5 \\
0.3\end{array}$ & 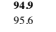 & $\begin{array}{l}35 \\
38\end{array}$ \\
\hline r. & 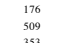 & $\begin{array}{l}85 \\
228\end{array}$ & 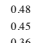 & $\begin{array}{l}106 \\
5620 \\
562\end{array}$ & & 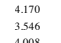 & $\begin{array}{l}0.094 \\
0.098\end{array}$ & 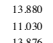 & 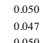 & 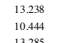 & $\begin{array}{l}0.0 \\
02\end{array}$ & $\begin{array}{l}9.65 \\
\text { o.68 }\end{array}$ & $\begin{array}{l}40 \\
{ }_{34}^{0}\end{array}$ & $\begin{array}{l}10003 \\
\text { os }\end{array}$ & $\begin{array}{l}132 \\
1000\end{array}$ & 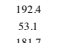 & 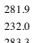 & $\begin{array}{l}38 \\
-18 \\
18\end{array}$ & $\begin{array}{l}0.3 \\
0.02\end{array}$ & $\begin{array}{l}905 \\
0.08\end{array}$ & $\begin{array}{l}40 \\
3.4\end{array}$ \\
\hline 1) & $\begin{array}{l}531 \\
571 \\
201\end{array}$ & 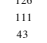 & $\begin{array}{l}0.9 \\
0.919 \\
0.21\end{array}$ & 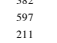 & & 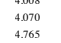 & 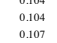 & 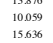 & 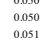 & 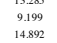 & $\begin{array}{l}02 \\
02 \\
00\end{array}$ & 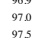 & $\begin{array}{l}30 \\
39 \\
46\end{array}$ & 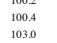 & $\begin{array}{l}96 \\
162\end{array}$ & $\begin{array}{c}\text { isos } \\
20220\end{array}$ & 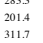 & $\begin{array}{l}3.3 \\
33 \\
53\end{array}$ & $\begin{array}{l}0.4 \\
0.4 \\
0.4\end{array}$ & $\begin{array}{l}970 \\
97,5\end{array}$ & 89 \\
\hline 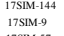 & & 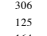 & $\begin{array}{l}0.17 \\
0.08\end{array}$ & $\begin{array}{l}18700 \\
15890\end{array}$ & & & 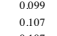 & $\begin{array}{l}5.533 \\
6427\end{array}$ & $\begin{array}{l}\text { out7 } \\
\text { oaso }\end{array}$ & $\begin{array}{l}424651 \\
5,431\end{array}$ & $\begin{array}{l}0.6 \\
0.5\end{array}$ & $\begin{array}{l}979 \\
9919\end{array}$ & $\begin{array}{l}3.4 \\
344\end{array}$ & $\begin{array}{l}960 \\
1034\end{array}$ & $\begin{array}{l}50 \\
63 \\
63\end{array}$ & $\begin{array}{l}4999.7 \\
2047\end{array}$ & $\begin{array}{l}9.88 \\
21214\end{array}$ & $\begin{array}{l}-199 \\
42\end{array}$ & $\begin{array}{l}-0.4 \\
0.74\end{array}$ & $\begin{array}{l}979 \\
9919\end{array}$ & 3.4 \\
\hline 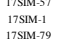 & $\begin{array}{l}871 \\
2311\end{array}$ & $\begin{array}{l}164 \\
1104\end{array}$ & $\begin{array}{l}0.19 \\
0.05\end{array}$ & $\begin{array}{l}910 \\
213\end{array}$ & & $\begin{array}{l}5.4665 \\
3,38\end{array}$ & $\begin{array}{l}0.107 \\
0.107\end{array}$ & 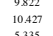 & 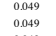 & $\begin{array}{l}8.1860 \\
9871\end{array}$ & $\begin{array}{l}0.5 \\
0.1\end{array}$ & $\begin{array}{l}1017 \\
10217\end{array}$ & $\begin{array}{l}5.5 \\
344\end{array}$ & $\begin{array}{l}10393 \\
01032\end{array}$ & $\begin{array}{l}96 \\
1002\end{array}$ & $\begin{array}{l}140999 \\
1298\end{array}$ & $\begin{array}{l}\text { 18411 } \\
2171\end{array}$ & $\begin{array}{l}1.6 \\
1.1\end{array}$ & $\begin{array}{l}0.2 \\
0.1\end{array}$ & $\begin{array}{l}1017.7 \\
1022 .\end{array}$ & $\begin{array}{l}5.5 \\
3.4\end{array}$ \\
\hline 1) & 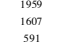 & 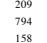 & $\begin{array}{l}\text { out } \\
\text { o.49 } \\
\text { of }\end{array}$ & 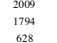 & & 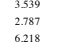 & $\begin{array}{l}0.111 \\
0.114 \\
0103\end{array}$ & 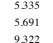 & 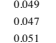 & 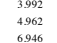 & $\begin{array}{l}06 \\
0.96 \\
0.6\end{array}$ & 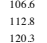 & 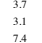 & 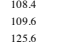 & $\begin{array}{l}55 \\
\text { sis } \\
100\end{array}$ & 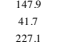 & 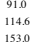 & $\begin{array}{l}17 \\
2.9 \\
42\end{array}$ & $\begin{array}{l}0.00 \\
0.03 \\
0.5\end{array}$ & 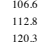 & $\begin{array}{l}37 \\
37 \\
71 \\
7\end{array}$ \\
\hline 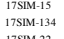 & 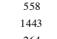 & $\begin{array}{l}268 \\
518\end{array}$ & $\begin{array}{l}\text { oft8 } \\
0.36\end{array}$ & 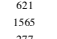 & & $\begin{array}{l}3.305 \\
10652\end{array}$ & $\begin{array}{l}0.132 \\
0.49 \\
0.40\end{array}$ & $\begin{array}{l}7.4121 \\
\text { cilso }\end{array}$ & $\begin{array}{l}\text { oforis } \\
\text { oats }\end{array}$ & $\begin{array}{l}6.712 \\
5909\end{array}$ & $\begin{array}{l}0.3 \\
0.1\end{array}$ & $\begin{array}{l}11066 \\
19393\end{array}$ & $\begin{array}{l}{ }_{2.1}^{4.1} \\
23\end{array}$ & 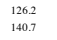 & $\begin{array}{l}8.8 \\
80 \\
80\end{array}$ & $\begin{array}{l}11898 \\
1663\end{array}$ & $\begin{array}{l}1.100 \\
1325\end{array}$ & 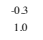 & $\begin{array}{l}0.0 \\
02 \\
02\end{array}$ & 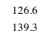 & ${ }_{23}$ \\
\hline 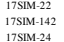 & 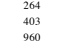 & $\begin{array}{c}278 \\
208 \\
688\end{array}$ & $\begin{array}{l}0.22 \\
0.522 \\
0.72\end{array}$ & 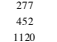 & & 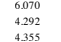 & 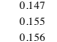 & 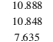 & 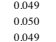 & 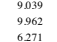 & $\begin{array}{l}0.5 \\
0.5 \\
0.5\end{array}$ & 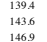 & $\begin{array}{l}8.7 \\
6.7 \\
6,1\end{array}$ & 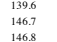 & 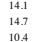 & 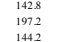 & 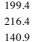 & 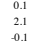 & 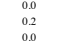 & 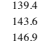 & $\begin{array}{l}61 \\
6.3\end{array}$ \\
\hline 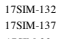 & $\begin{array}{l}799 \\
476\end{array}$ & ${ }_{81}^{119}$ & $\begin{array}{l}\begin{array}{l}1.20 \\
0.17\end{array} \\
0.0\end{array}$ & $\begin{array}{l}102 \\
405 \\
405\end{array}$ & & $\begin{array}{l}4.2989 \\
4.851\end{array}$ & $\begin{array}{l}0.066 \\
0.162\end{array}$ & $\begin{array}{l}101312 \\
\text { o:29 }\end{array}$ & $\begin{array}{l}0.051 \\
0.055\end{array}$ & $\begin{array}{l}93777 \\
8.466\end{array}$ & $\begin{array}{l}03 \\
0.3 \\
04\end{array}$ & $\begin{array}{l}1002 \\
1315\end{array}$ & 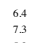 & $\begin{array}{l}1561.1 \\
15282\end{array}$ & 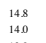 & $\begin{array}{l}24676 \\
1426\end{array}$ & $\begin{array}{l}2027 \\
0.027\end{array}$ & $\begin{array}{l}38 \\
38 \\
08\end{array}$ & $\begin{array}{l}0.4 \\
0.1 \\
0.1\end{array}$ & $\begin{array}{l}1502 \\
1015\end{array}$ & 13 \\
\hline 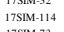 & 321 & 324 & $\begin{array}{l}0.62 \\
0.31\end{array}$ & (3) & & & $\begin{array}{l}0.1698 \\
0.163\end{array}$ & $\begin{array}{l}9.129 \\
13047\end{array}$ & 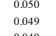 & $\begin{array}{l}\frac{8}{21245} \\
1243\end{array}$ & $\begin{array}{l}0.3 \\
02 \\
0.25\end{array}$ & $\begin{array}{l}1.1344 \\
1540\end{array}$ & $\begin{array}{l}5.8 \\
6.0\end{array}$ & $\begin{array}{l}1.443 \\
1,33\end{array}$ & $\begin{array}{l}180.8 \\
18.4\end{array}$ & 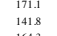 & $\begin{array}{l}18380 \\
8884\end{array}$ & $\begin{array}{l}0.7 \\
.0 .5\end{array}$ & $\begin{array}{l}0.1 \\
0.00\end{array}$ & $\begin{array}{l}15344 \\
1540\end{array}$ & 5.8 \\
\hline trism: & $\begin{array}{l}2101 \\
149 \\
409\end{array}$ & $\begin{array}{l}118 \\
142 \\
472\end{array}$ & $\begin{array}{l}0.59 \\
0.96 \\
0.84\end{array}$ & 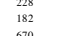 & & 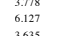 & $\begin{array}{l}0.109 \\
0.177\end{array}$ & 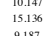 & $\begin{array}{l}\text { oras } \\
\text { ossi }\end{array}$ & 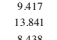 & $\begin{array}{l}02 \\
0.2\end{array}$ & $\begin{array}{l}1.1779 \\
1005\end{array}$ & $\begin{array}{l}59 \\
9.7 \\
98\end{array}$ & 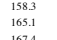 & $\begin{array}{l}1.188 \\
228\end{array}$ & $\begin{array}{l}16193 \\
2315 \\
213\end{array}$ & 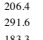 & $\begin{array}{l}0.3 \\
2.8 \\
28\end{array}$ & $\begin{array}{l}x_{0.0} \\
02\end{array}$ & $\begin{array}{l}101790 \\
1005\end{array}$ & 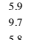 \\
\hline 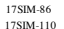 & $\begin{array}{l}245 \\
\text { ats }\end{array}$ & & 1.28 & 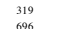 & & & $\begin{array}{l}0,180 \\
0.87 \\
0\end{array}$ & 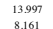 & $\begin{array}{l}0.052 \\
\text { osese }\end{array}$ & 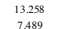 & $\begin{array}{l}0.1 \\
{ }_{0.3}\end{array}$ & 10166 & 72 & $\begin{array}{l}1882 \\
1085\end{array}$ & 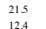 & $\begin{array}{l}2624 \\
2024\end{array}$ & $\begin{array}{l}2789 \\
1840\end{array}$ & 39. & $\begin{array}{l}0.3 \\
0.3\end{array}$ & & \\
\hline $1 \mathrm{rsm}, \mathrm{se}$ & 377 & $\frac{272}{272}$ & 0 & $\frac{4+1}{4+1}$ & & & 0.175 & 606080 & $\begin{array}{l}00080 \\
0.08\end{array}$ & $\begin{array}{l}\text { 2alk9 } \\
\text { sate }\end{array}$ & $\begin{array}{l}0.3 \\
0.3\end{array}$ & $\begin{array}{l}1021 \\
1024\end{array}$ & $\begin{array}{l}5.2 \\
4.8\end{array}$ & $\begin{array}{l}1656.6 \\
163,7\end{array}$ & $\begin{array}{l}1024 \\
1000\end{array}$ & $\begin{array}{l}2157 \\
1817\end{array}$ & $\begin{array}{l}10488 \\
1330\end{array}$ & $\begin{array}{l}2.1 \\
0.8\end{array}$ & $\begin{array}{l}0.3 \\
0.1\end{array}$ & $\begin{array}{l}1621 \\
1624\end{array}$ & $\begin{array}{l}52 \\
48\end{array}$ \\
\hline 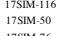 & 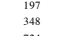 & $\begin{array}{l}1506 \\
208\end{array}$ & $\begin{array}{l}0.979 \\
0.000\end{array}$ & $\begin{array}{l}233 \\
\text { 2397 }\end{array}$ & & $\begin{array}{l}\text { ans? } \\
3.567\end{array}$ & $\begin{array}{l}0.179 \\
0.172\end{array}$ & $\begin{array}{l}10,795 \\
0.332\end{array}$ & $\begin{array}{l}\text { oosi } \\
\text { out9 }\end{array}$ & $\begin{array}{l}9.9938 \\
8.645\end{array}$ & $\begin{array}{l}0.2 \\
0.3\end{array}$ & $\begin{array}{l}1627 \\
16822\end{array}$ & $\begin{array}{l}6.6 \\
5.7\end{array}$ & $\begin{array}{l}16727 \\
161.1\end{array}$ & $\begin{array}{l}1.65 \\
1399\end{array}$ & $\begin{array}{l}2321 \\
1838 \\
182\end{array}$ & $\begin{array}{l}2151727 \\
1914\end{array}$ & $\begin{array}{l}2.7 \\
-1.0\end{array}$ & $\begin{array}{l}0.3 \\
-0.13\end{array}$ & $\begin{array}{l}1272 \\
1632\end{array}$ & 5.7 \\
\hline 17) & $\begin{array}{l}724 \\
147 \\
677\end{array}$ & 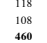 & 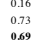 & 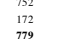 & & 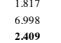 & 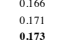 & 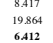 & 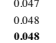 & 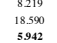 & 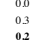 & 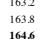 & 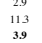 & 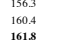 & 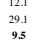 & 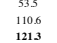 & 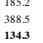 & 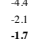 & 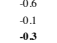 & 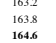 & 3.9 \\
\hline 1,sMM-s & & & 0.23 & 497 & & & 0.186 & 6.164 & & 4908 & & & & & 111.7 & & & 40 & 00 & & \\
\hline IrSM & $\begin{array}{l}520 \\
5,208\end{array}$ & 261 & $\begin{array}{l}0.50 \\
\text { o. }\end{array}$ & $\begin{array}{l}582 \\
\text { sis }\end{array}$ & & & $\begin{array}{l}0,1738 \\
0.188 \\
0.18\end{array}$ & $\begin{array}{l}6.343 \\
\text { sust }\end{array}$ & $\begin{array}{llll}\text { outs } \\
\text { ost }\end{array}$ & 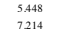 & 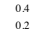 & 1672.1 & ${ }_{4 t}$ & 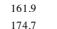 & $\begin{array}{l}9.4 \\
10.5\end{array}$ & $\begin{array}{l}870 \\
2003\end{array}$ & 1243 & 32 & .0.5. & 1672.1 & ${ }_{54}$ \\
\hline IISTM-37. & $\begin{array}{l}256 \\
4 \\
483\end{array}$ & $\begin{array}{l}1,44 \\
4\end{array}$ & $\begin{array}{l}0.000 \\
0.00\end{array}$ & $\begin{array}{l}292, \\
40,3\end{array}$ & & $\begin{array}{l}5.719 \\
2068\end{array}$ & $\begin{array}{l}0.194 \\
0.189\end{array}$ & 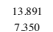 & $\begin{array}{l}0.0533 \\
0.040\end{array}$ & $\begin{array}{l}12.59 \\
6.844\end{array}$ & 0.3 & $\begin{array}{l}10000 \\
10020\end{array}$ & $\begin{array}{l}9.5 \\
45\end{array}$ & $\begin{array}{l}11999 \\
11922\end{array}$ & 22.6 & $\begin{array}{l}3255 \\
21254\end{array}$ & 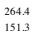 & $\begin{array}{c}6.1 \\
17\end{array}$ & $\begin{array}{l}0.5 \\
0.5\end{array}$ & $\begin{array}{l}10090 \\
10900\end{array}$ & 95 \\
\hline 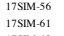 & $\begin{array}{l}1216 \\
577 \\
57\end{array}$ & $\begin{array}{l}309 \\
6379\end{array}$ & $\begin{array}{l}0.25 \\
1.1 .1\end{array}$ & 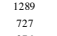 & & $\begin{array}{l}2.675 \\
4.996\end{array}$ & $\begin{array}{l}0.0177 \\
0.185\end{array}$ & $\begin{array}{l}5,711 \\
\text { solo }\end{array}$ & $\begin{array}{l}\text { outs } \\
\text { oser }\end{array}$ & $\begin{array}{l}50688 \\
7.918\end{array}$ & $\begin{array}{l}0.4 \\
0.4\end{array}$ & $\begin{array}{l}170404 \\
1705\end{array}$ & $\begin{array}{l}45 \\
6.9\end{array}$ & $\begin{array}{l}1058 \mathrm{~s} \\
11222\end{array}$ & $\begin{array}{l}8.7 \\
140\end{array}$ & $\begin{array}{l}101016 \\
1988\end{array}$ & $\begin{array}{l}1,5177 \\
1442\end{array}$ & $\begin{array}{l}2.7 \\
1.0\end{array}$ & $\begin{array}{l}.0 .5 \\
0.1\end{array}$ & $\begin{array}{l}104 \\
1005\end{array}$ & \\
\hline 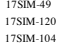 & $\begin{array}{l}260 \\
227 \\
3.97\end{array}$ & $\begin{array}{l}212 \\
2135 \\
195\end{array}$ & 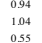 & 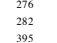 & & 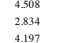 & 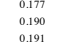 & 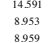 & $\begin{array}{l}\text { outs } \\
\text { oshis } \\
\text { osal }\end{array}$ & 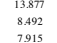 & $\begin{array}{l}0.0 \\
0.0 \\
0.5\end{array}$ & 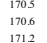 & $\begin{array}{l}76 \\
4.6 \\
7.8\end{array}$ & 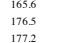 & $\begin{array}{l}2.21 \\
1.44 \\
145\end{array}$ & 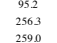 & $\begin{array}{l}18+33 \\
1043\end{array}$ & $\begin{array}{l}-30 \\
3.3 \\
3.3\end{array}$ & 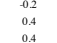 & 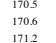 & \\
\hline 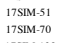 & $\begin{array}{l}1147 \\
1114\end{array}$ & $\begin{array}{l}1115 \\
11158\end{array}$ & $\begin{array}{l}0.97 \\
0.12\end{array}$ & $\begin{array}{l}\text { tuts } \\
\text { Itar }\end{array}$ & & $\begin{array}{l}2.857 \\
1517\end{array}$ & $\begin{array}{l}0.187 \\
0.189 \\
0.197\end{array}$ & $\begin{array}{l}5.500 \\
85500\end{array}$ & $\begin{array}{l}\text { oseso } \\
\text { oses }\end{array}$ & 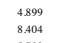 & 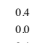 & $\begin{array}{l}1715 \\
17131 \\
1730\end{array}$ & 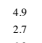 & $\begin{array}{l}1718 \mathrm{~s} \\
1760\end{array}$ & $\begin{array}{l}90 \\
0.97\end{array}$ & 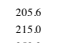 & $\begin{array}{l}10088 \\
10858\end{array}$ & 1.6 & $\begin{array}{l}0.3 \\
0.2 \\
0.2\end{array}$ & 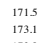 & 2.7 \\
\hline 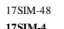 & 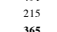 & 27 & 0.91 & 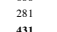 & & & 0 & 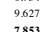 & 00050 & 8965 & 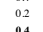 & & & $=$ & 135 & 2018 & 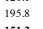 & 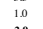 & 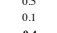 & 1738 & \\
\hline trss & $\begin{array}{l}1092 \\
0.942\end{array}$ & 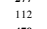 & $\begin{array}{l}0.11 \\
0.11\end{array}$ & $\begin{array}{l}1000 \\
1000\end{array}$ & & & 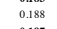 & 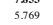 & $\begin{array}{l}\text { outs } \\
\text { outs }\end{array}$ & 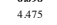 & 告 & 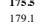 & & 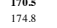 & $\begin{array}{l}1,22 \\
9_{2}\end{array}$ & 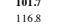 & 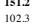 & 2.29 & $\begin{array}{l}-20 \\
0.04\end{array}$ & 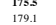 & \\
\hline & 827 & 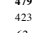 & $\begin{array}{l}0.87 \\
0.80\end{array}$ & $\begin{array}{l}957 \\
628\end{array}$ & & & $\begin{array}{l}0.197 \\
0201\end{array}$ & & 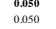 & 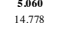 & ${ }_{4}^{4}$ & $\begin{array}{l}18085 \\
1844\end{array}$ & & 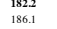 & $\begin{array}{l}9.7 \\
2773\end{array}$ & 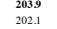 & (1) & 0.7 & $\begin{array}{l}0.2 \\
0.02\end{array}$ & $\begin{array}{l}18085 \\
1849\end{array}$ & \\
\hline trism & 256 & & 0.59 & 291 & & $85622^{2}$ & 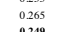 & 285816 & $\begin{array}{l}0035 \\
\end{array}$ & 24385 & 02 & $\begin{array}{l}12203 \\
2020\end{array}$ & 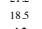 & $\begin{array}{l}21280 \\
2386,\end{array}$ & 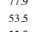 & $\begin{array}{l}45853 \\
4206\end{array}$ & $\begin{array}{l}7699.9 \\
467.8\end{array}$ & & $\begin{array}{l}0.3 \\
0.3\end{array}$ & 20200 & \\
\hline trst & $\begin{array}{l}3799 \\
279\end{array}$ & $\begin{array}{l}578 \\
178 \\
6\end{array}$ & $\begin{array}{l}0.14 \\
0.64\end{array}$ & $\begin{array}{l}4212 \\
3212\end{array}$ & & 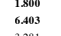 & $\begin{array}{l}0.219 \\
0.276\end{array}$ & $\begin{array}{l}5.9400 \\
120692\end{array}$ & $\begin{array}{l}\text { ofols } \\
\text { oals }\end{array}$ & $\begin{array}{l}5.1 .187 \\
\text { 1.0.959 }\end{array}$ & 量 & 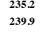 & $\begin{array}{l}4.2 \\
15.1\end{array}$ & $\begin{array}{l}24256 \\
247,7\end{array}$ & $\begin{array}{l}1010 \\
275\end{array}$ & $\begin{array}{l}121272 \\
321.1\end{array}$ & 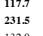 & $\begin{array}{l}4.2 \\
3.1\end{array}$ & $\begin{array}{l}-0.99 \\
0.3\end{array}$ & $\begin{array}{l}2332 \\
{ }_{23}^{2399}\end{array}$ & \\
\hline 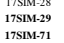 & 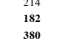 & $\begin{array}{l}122 \\
122 \\
220\end{array}$ & $\begin{array}{l}0.02 \\
0.028 \\
0.58\end{array}$ & 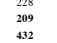 & & 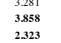 & 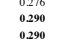 & 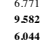 & 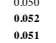 & 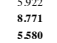 & $\begin{array}{l}0.2 \\
0.27 \\
0.2\end{array}$ & 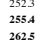 & $\begin{array}{l}9,7 \\
60.0\end{array}$ & 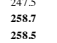 & 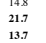 & 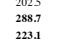 & 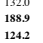 & $\begin{array}{l}.19 \\
1.3 \\
.1 .5\end{array}$ & $\begin{array}{l}0.3 \\
0.02 \\
.0 .3\end{array}$ & 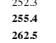 & \\
\hline 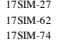 & 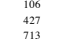 & $\begin{array}{l}1883 \\
203\end{array}$ & $\begin{array}{c}0,43 \\
028\end{array}$ & $\begin{array}{l}1140 \\
7 \\
700\end{array}$ & & 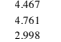 & $\begin{array}{l}0.281 \\
02921 \\
0.313\end{array}$ & $\begin{array}{l}8889 \\
52293\end{array}$ & 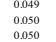 & 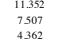 & $\begin{array}{l}0_{02}^{2} \\
03 \\
0.5\end{array}$ & 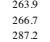 & $\begin{array}{l}12.4 \\
84\end{array}$ & 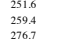 & $\begin{array}{l}2.868 \\
2017 \\
127\end{array}$ & 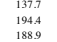 & $\begin{array}{l}1658 \\
1058\end{array}$ & 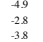 & $\begin{array}{l}\text { s. } \\
\text { of } \\
0.8\end{array}$ & 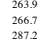 & \\
\hline
\end{tabular}




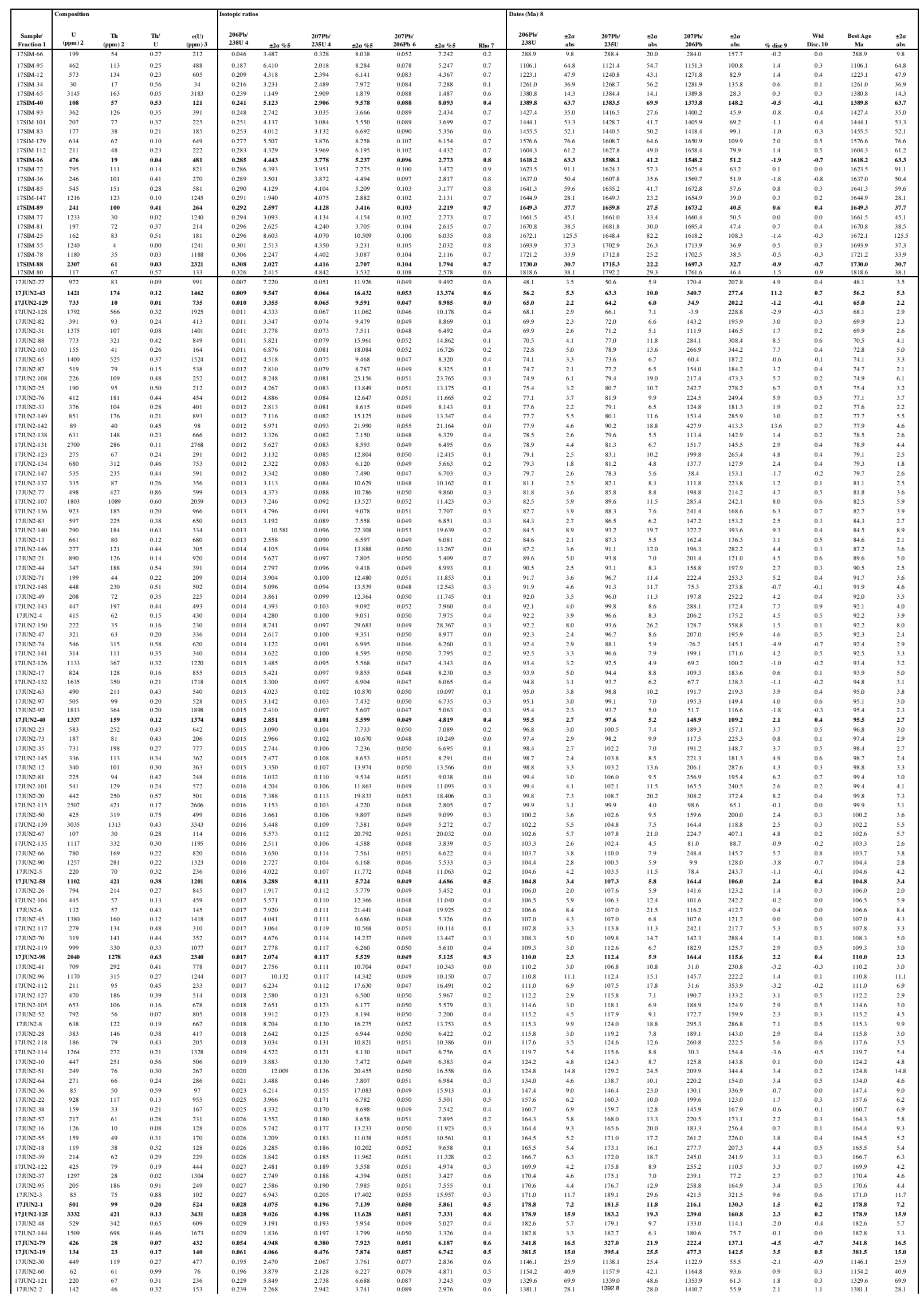




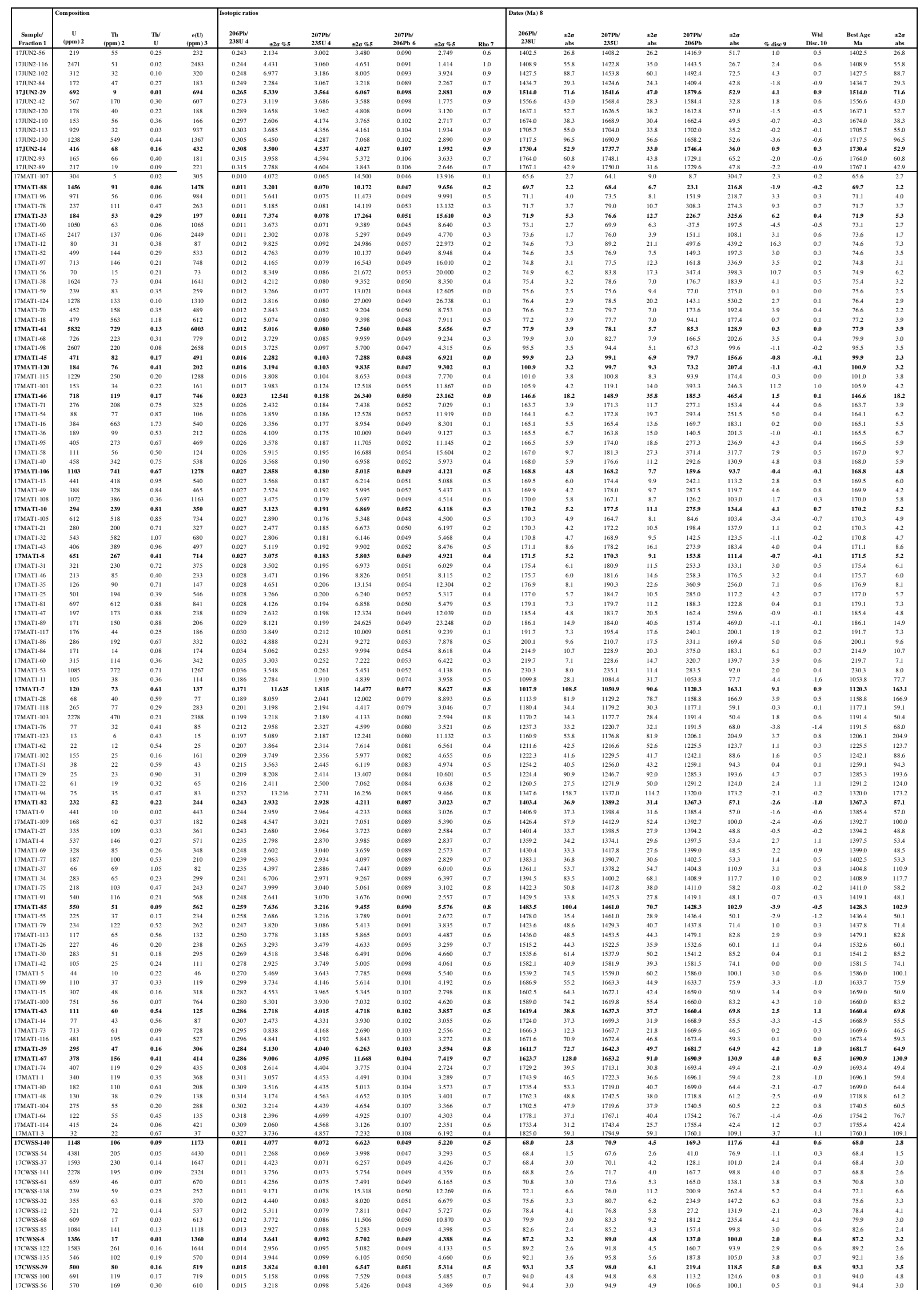




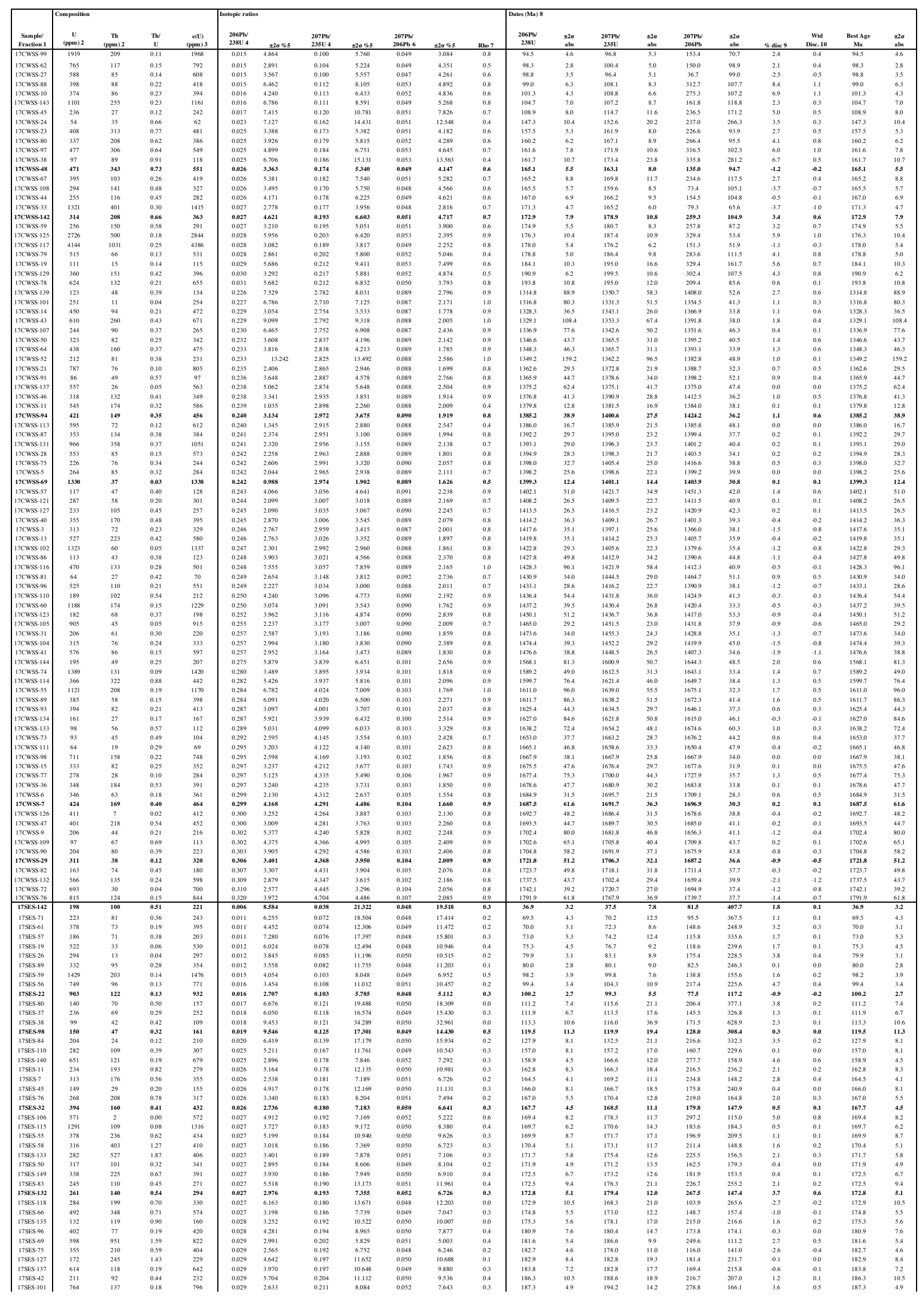




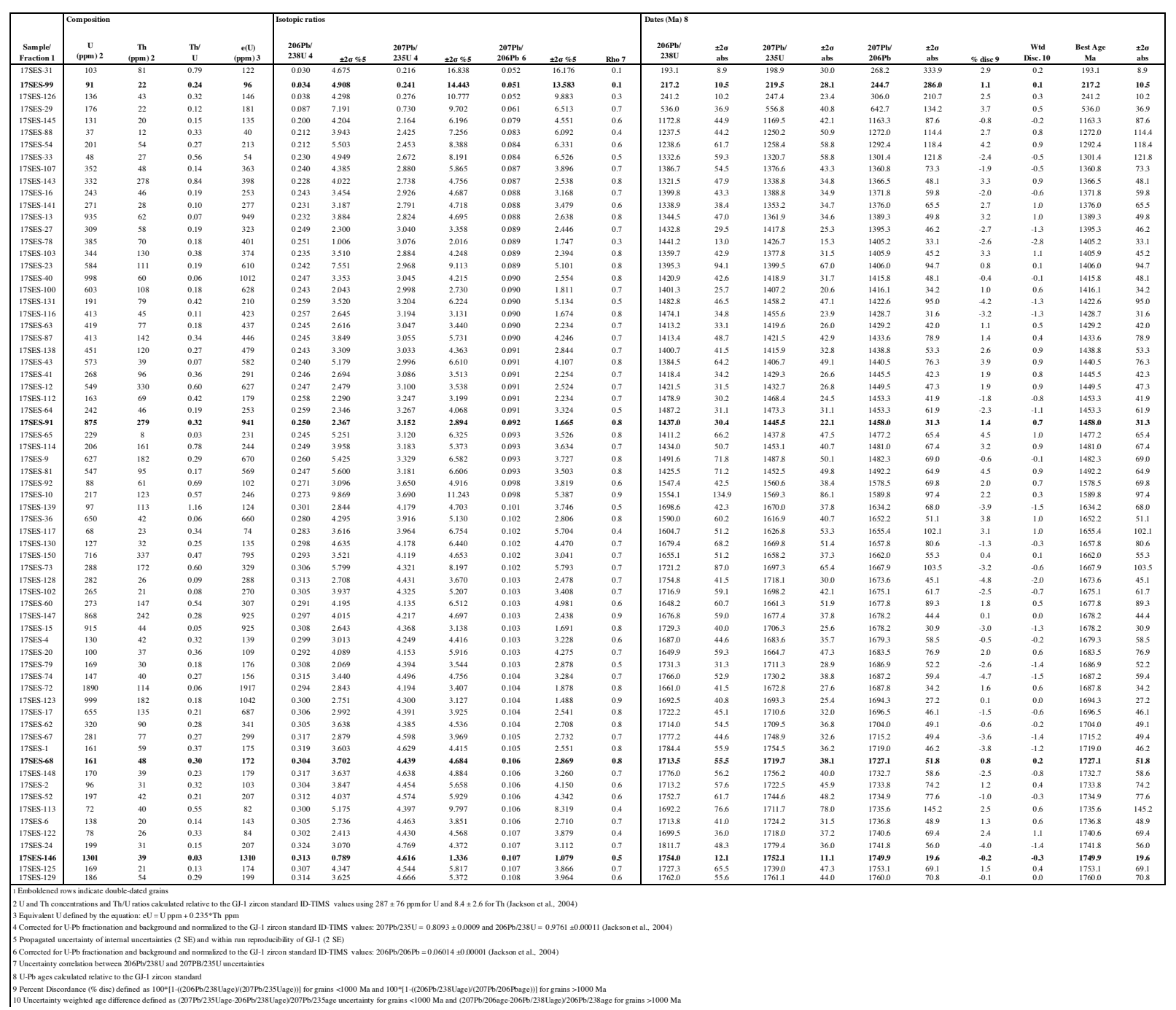



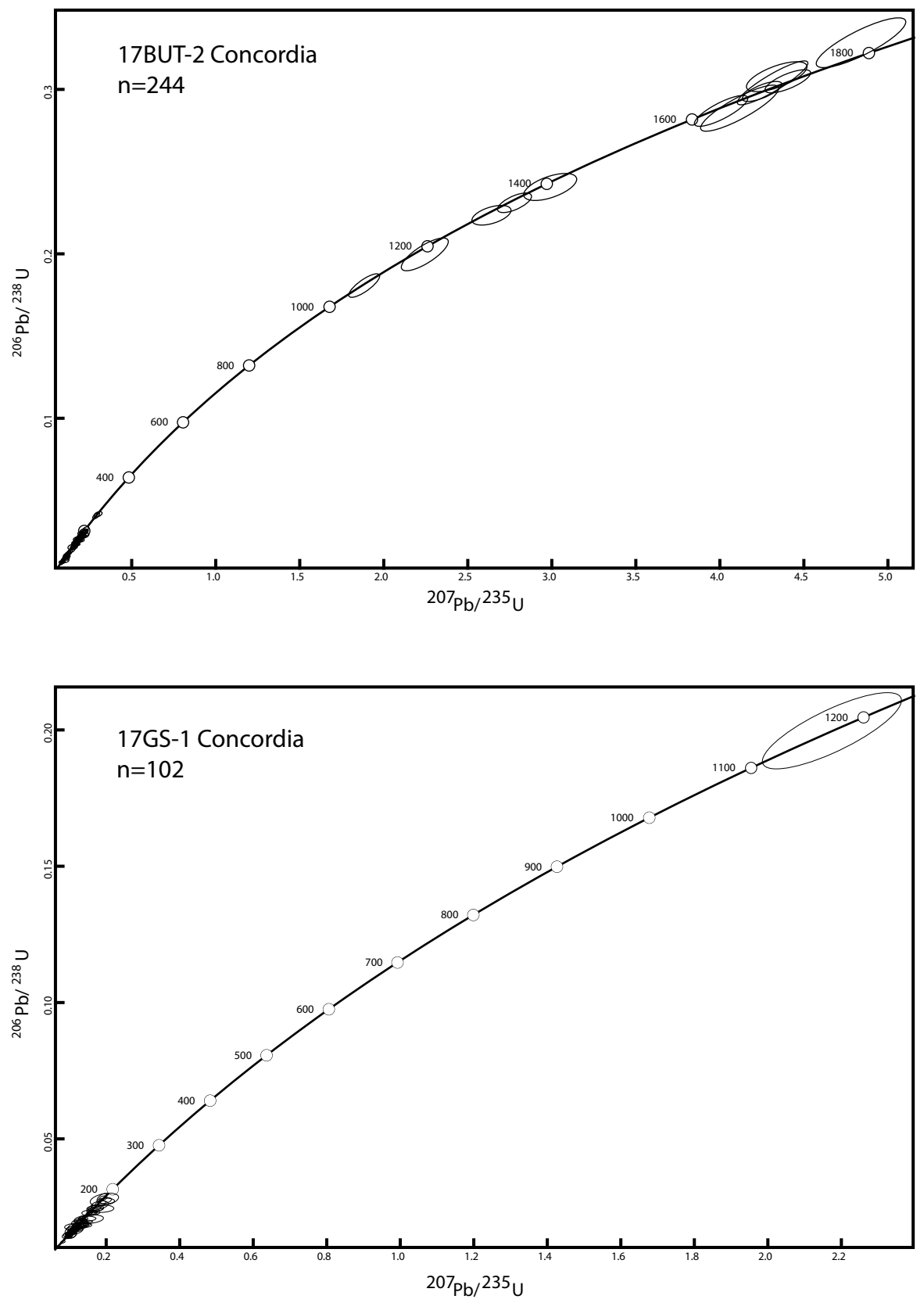

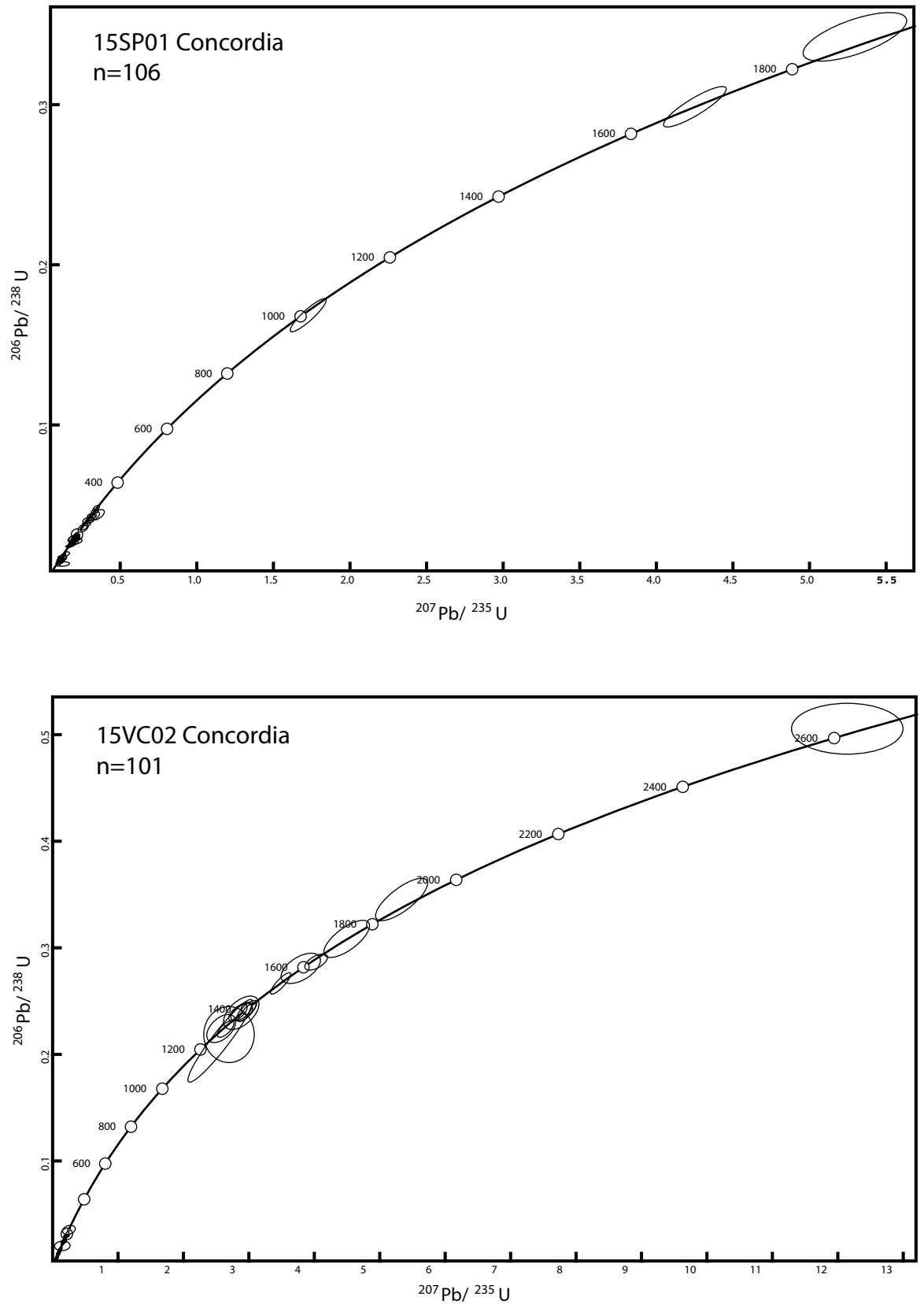

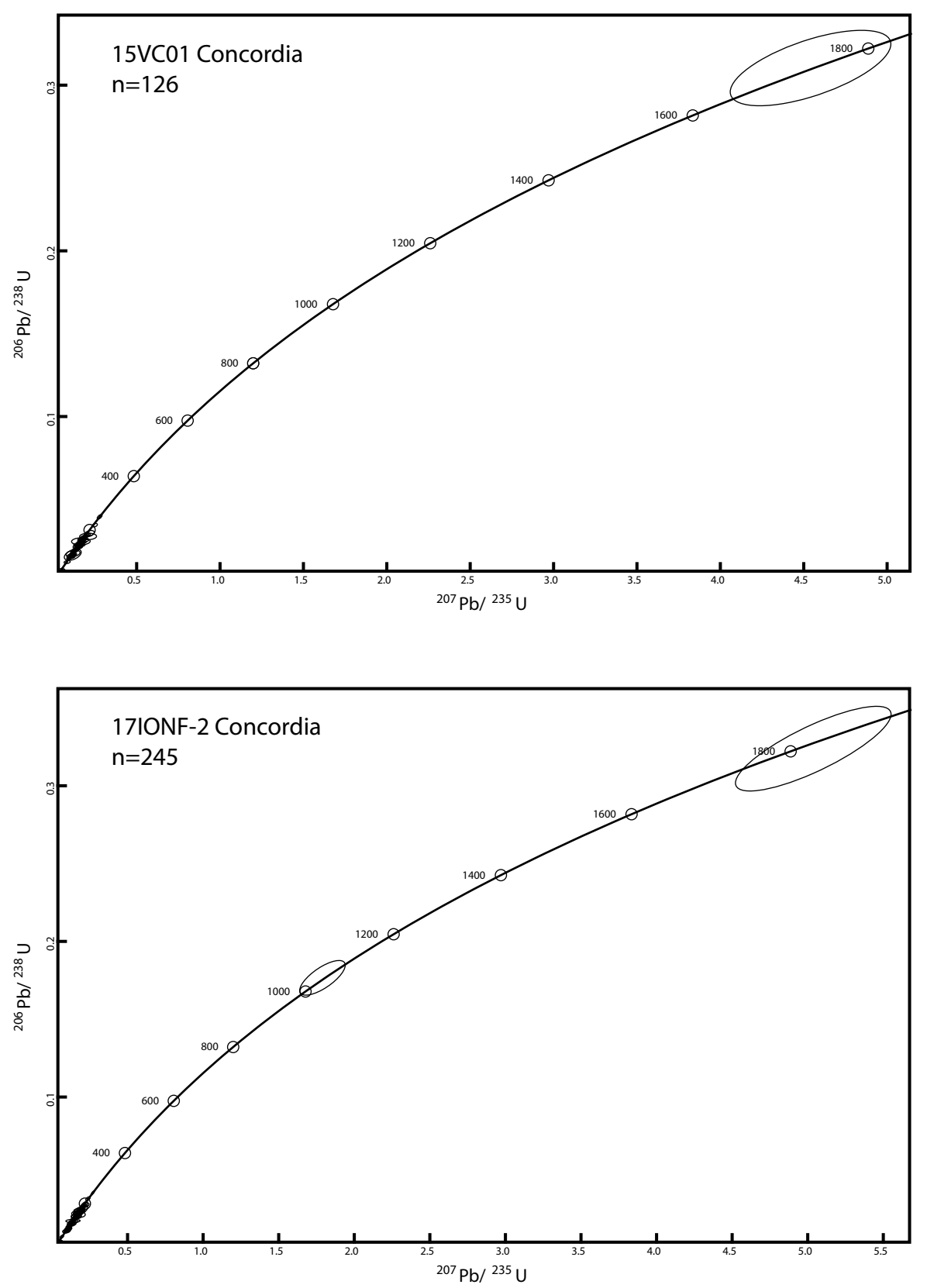

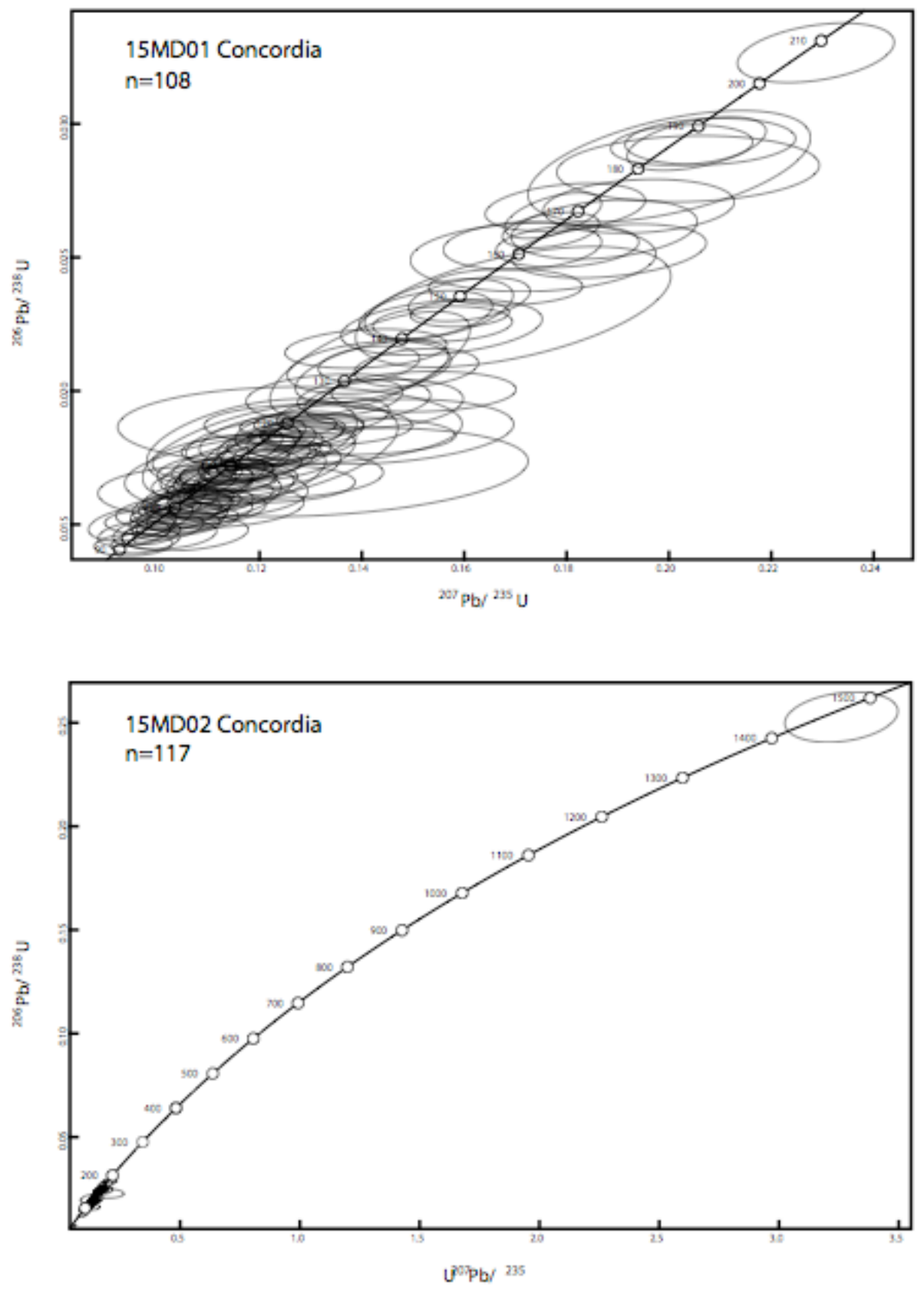

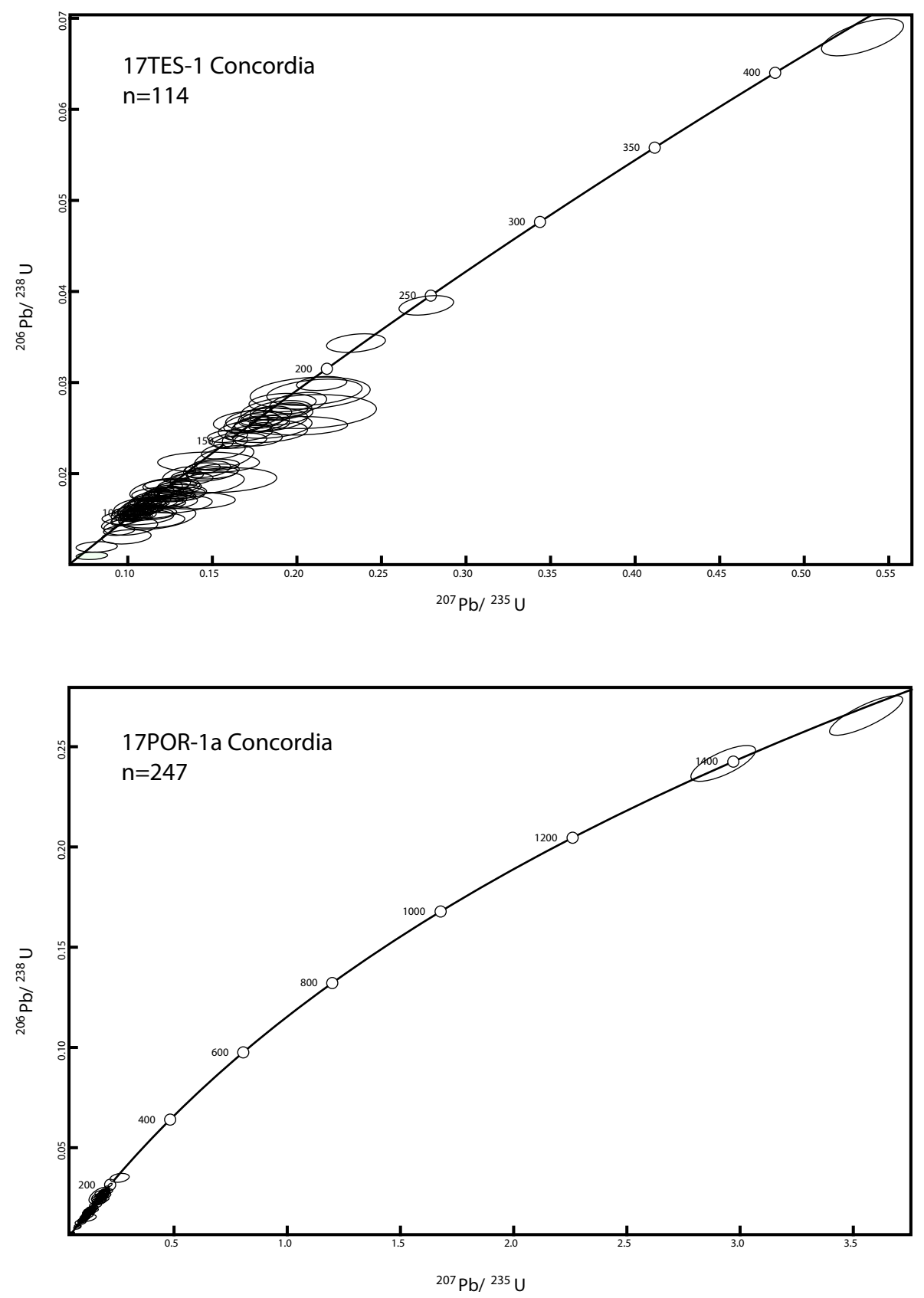

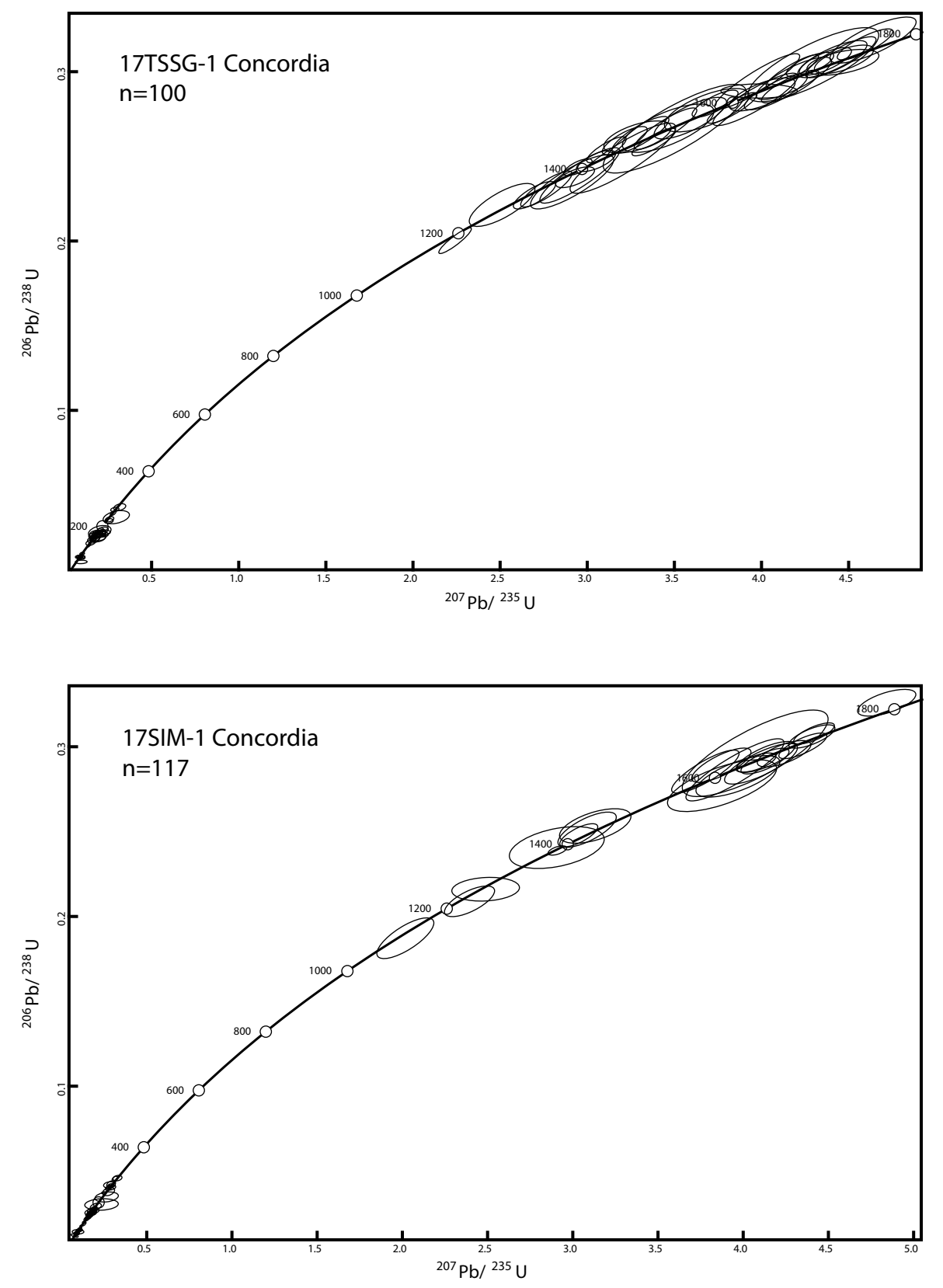

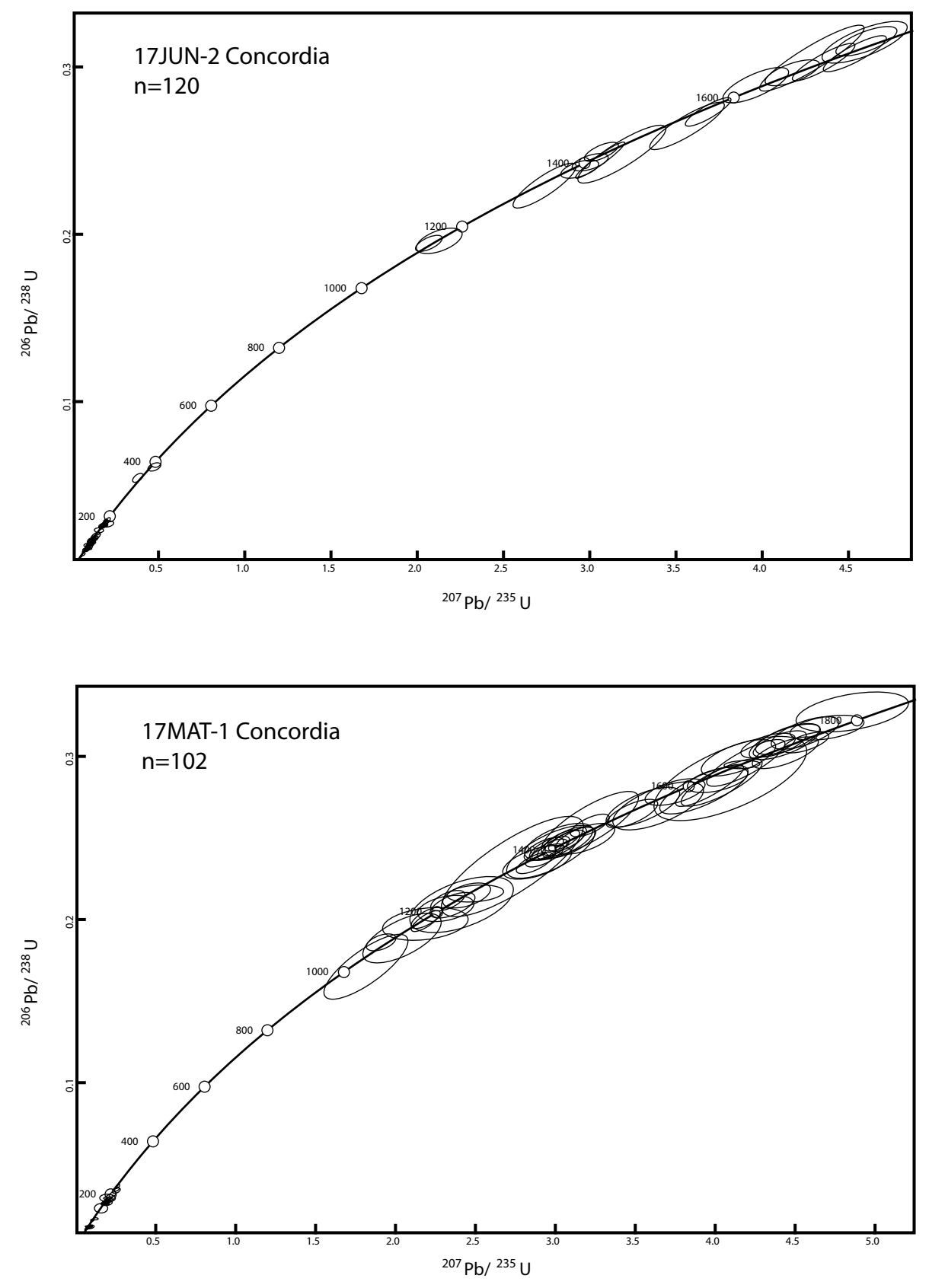

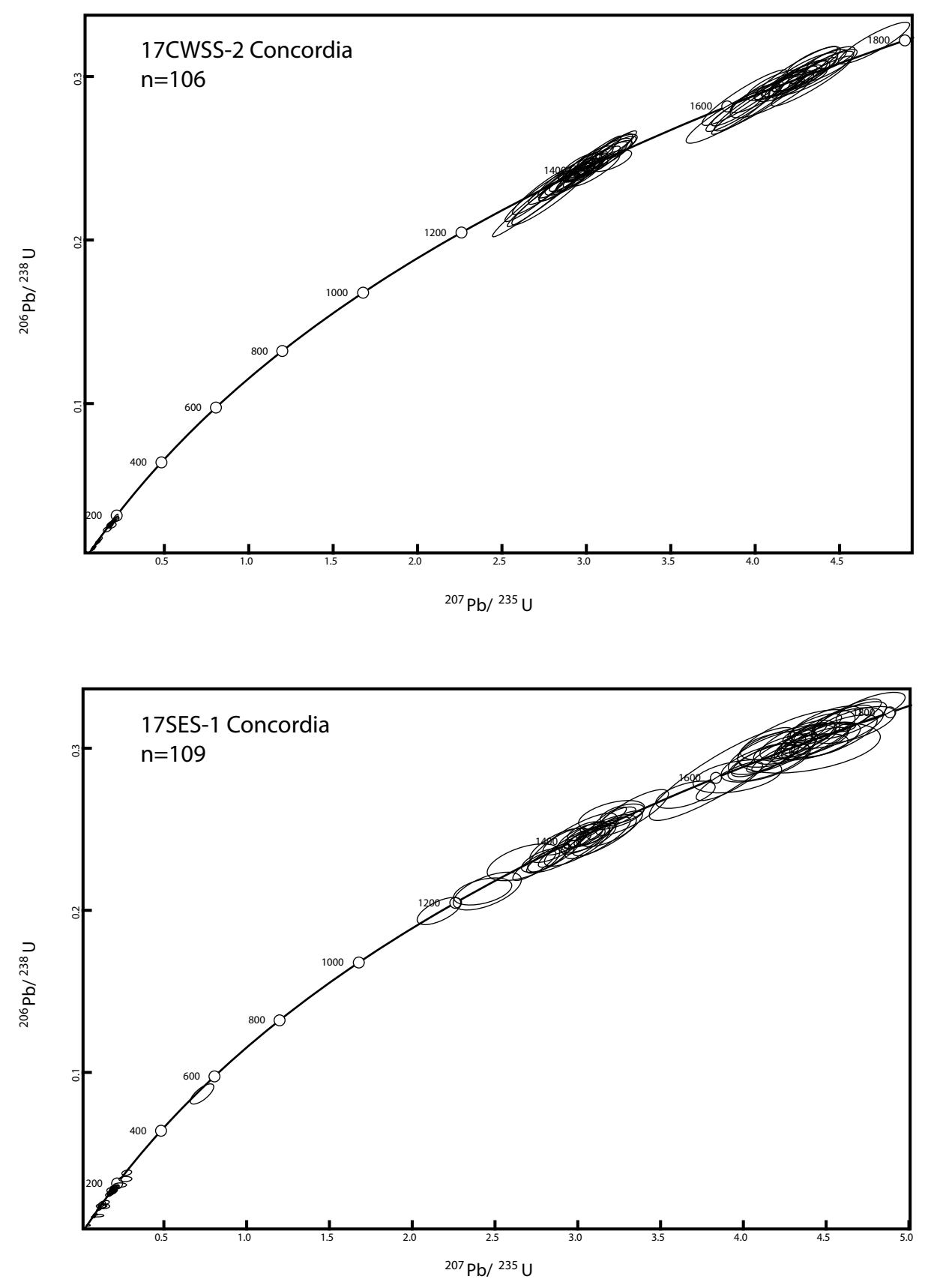
Appendix 5. (U-Th)/He Data Table

\begin{tabular}{|c|c|c|c|c|c|c|c|c|c|c|c|c|}
\hline Sample & Grain & $\begin{array}{l}\text { Age } \\
\text { (Ma) }\end{array}$ & $\begin{array}{l}\text { Std } \\
\text { Err. } \\
\left(\mathrm{Ma}^{*}\right)\end{array}$ & $\begin{array}{c}\mathrm{U} \\
(\mathbf{p p m})\end{array}$ & $\begin{array}{c}\text { Th } \\
\text { (ppm) }\end{array}$ & $\begin{array}{l}\text { 147Sm } \\
(\mathbf{p p m})\end{array}$ & eU* & $\mathrm{Th} / \mathrm{U}$ & $\begin{array}{c}\mathrm{He} \\
(\mathbf{n m o l} / \mathbf{g})\end{array}$ & $\begin{array}{c}\text { Mass } \\
\text { (ug) }\end{array}$ & $\mathbf{F t}^{*}$ & ESR* \\
\hline \multirow{10}{*}{$\begin{array}{r}\text { 17BUT- } \\
1\end{array}$} & 268 & 50.7 & 4.06 & 708 & 344.4 & 0 & 787.3 & 0.49 & 123.3 & 0.67 & 0.57 & 25.18 \\
\hline & 158 & 54.4 & 4.35 & 763.2 & 340.8 & 0 & 841.6 & 0.45 & 164.1 & 1.47 & 0.66 & 33.27 \\
\hline & 285 & 63.2 & 5.05 & 140.1 & 75.9 & 0 & 157.6 & 0.54 & 38.9 & 2.79 & 0.72 & 41.54 \\
\hline & 261 & 63.9 & 5.12 & 126.6 & 65.6 & 4.3 & 141.7 & 0.52 & 34.5 & 2.19 & 0.7 & 38.58 \\
\hline & 20 & 64.5 & 5.16 & 242.1 & 142 & 0 & 274.8 & 0.59 & 63.3 & 1.44 & 0.66 & 33.15 \\
\hline & 50 & 65.3 & 5.22 & 221.2 & 20.2 & 0 & 225.8 & 0.09 & 51.7 & 1.14 & 0.65 & 30.96 \\
\hline & 210 & 71.5 & 5.72 & 230.6 & 186.4 & 0 & 273.5 & 0.81 & 74.4 & 2.52 & 0.7 & 38.73 \\
\hline & 216 & 82.2 & 6.58 & 91.5 & 116.4 & 0 & 118.3 & 1.27 & 35.8 & 1.79 & 0.68 & 36.07 \\
\hline & 12 & 90.1 & 7.2 & 98.2 & 24.4 & 0 & 103.9 & 0.25 & 36.3 & 2.53 & 0.71 & 39.75 \\
\hline & 54 & 108.2 & 8.65 & 487.2 & 201.3 & -7.1 & 533.5 & 0.41 & 198.7 & 1.33 & 0.63 & 30.3 \\
\hline \multirow[t]{7}{*}{ 17GS-1 } & 25 & 55.1 & 4.41 & 151.3 & 87 & 2.5 & 171.3 & 0.58 & 38 & 3.72 & 0.74 & 45.35 \\
\hline & 64 & 61.1 & 4.89 & 1100.7 & 271.7 & 0 & 1163.2 & 0.25 & 277.3 & 2.87 & 0.72 & 40.71 \\
\hline & 37 & 62.9 & 5.03 & 872.8 & 249.1 & 5.4 & 930.2 & 0.29 & 243.1 & 5.27 & 0.77 & 49.68 \\
\hline & 119 & 63.4 & 5.07 & 190.7 & 146.6 & 3.9 & 224.4 & 0.77 & 63.1 & 12.02 & 0.82 & 65.75 \\
\hline & 1 & 81.1 & 6.48 & 297.9 & 130.9 & 3.3 & 328.1 & 0.44 & 122.5 & 25.79 & 0.85 & 79.01 \\
\hline & 65 & 86.8 & 6.94 & 336.6 & 140.7 & 2.5 & 369 & 0.42 & 136.5 & 7.59 & 0.78 & 54.72 \\
\hline & 56 & 93.9 & 7.51 & 235.8 & 44.5 & 1.3 & 246.1 & 0.19 & 103.8 & 14.21 & 0.83 & 68.03 \\
\hline \multirow{12}{*}{$15 \mathrm{SP} 01$} & 130 & 57.5 & 4.6 & 157.1 & 111.1 & 0 & 182.7 & 0.71 & 39.8 & 2.29 & 0.7 & 38.38 \\
\hline & 144 & 57.7 & 4.61 & 162.9 & 62.5 & -4.1 & 177.3 & 0.38 & 38.8 & 2.27 & 0.7 & 38.11 \\
\hline & 133 & 58.4 & 4.67 & 239.5 & 123.4 & 0 & 267.9 & 0.52 & 55.7 & 1.7 & 0.66 & 32.89 \\
\hline & 1 & 60.8 & 4.87 & 113.6 & 57.9 & 0 & 127 & 0.51 & 32.2 & 5.5 & 0.77 & 50.64 \\
\hline & 28 & 62.5 & 5 & 170.8 & 68.6 & 18.1 & 186.6 & 0.4 & 40 & 1.04 & 0.63 & 30.16 \\
\hline & 11 & 63 & 5.04 & 387.8 & 61.5 & 0 & 401.9 & 0.16 & 86.2 & 1.06 & 0.63 & 29.31 \\
\hline & 59 & 65.9 & 5.27 & 282.9 & 212.5 & 3.1 & 331.8 & 0.75 & 82.9 & 3.08 & 0.7 & 38.35 \\
\hline & 135 & 68 & 5.44 & 123.6 & 37.7 & 0 & 132.2 & 0.3 & 38.6 & 7.16 & 0.79 & 56.13 \\
\hline & 40 & 70 & 5.6 & 423.5 & 262.6 & 2.9 & 483.9 & 0.62 & 131.9 & 3.22 & 0.72 & 41.07 \\
\hline & 5 & 74.3 & 5.95 & 433.6 & 168.7 & -5.6 & 472.4 & 0.39 & 124.5 & 1.67 & 0.65 & 32.28 \\
\hline & 85 & 77.7 & 6.22 & 175.8 & 59.7 & 0 & 189.5 & 0.34 & 55.3 & 2.61 & 0.69 & 36.84 \\
\hline & 138 & 84.9 & 6.79 & 350.9 & 204.4 & 0 & 397.9 & 0.58 & 104.4 & 0.8 & 0.57 & 25.27 \\
\hline \multirow[t]{12}{*}{$15 \mathrm{VCO} 2$} & 9 & 34.8 & 2.79 & 54.9 & 22.5 & 0 & 60.1 & 0.41 & 8.7 & 5.37 & 0.77 & 50.31 \\
\hline & 32 & 38.3 & 3.07 & 70.5 & 45.5 & 0 & 80.9 & 0.65 & 12.9 & 5.58 & 0.77 & 50.94 \\
\hline & 141 & 40.1 & 3.21 & 190 & 87.2 & 1.8 & 210.1 & 0.46 & 37.7 & 20.81 & 0.83 & 68.95 \\
\hline & 83 & 40.5 & 3.24 & 233.8 & 142.5 & 0 & 266.6 & 0.61 & 45 & 5.58 & 0.77 & 50.98 \\
\hline & 101 & 43.7 & 3.5 & 211.5 & 23 & 4.9 & 216.8 & 0.11 & 41 & 9.61 & 0.8 & 57.98 \\
\hline & 34 & 46 & 3.68 & 186 & 33.4 & -1 & 193.7 & 0.18 & 38.7 & 9.11 & 0.8 & 59.16 \\
\hline & 117 & 49.1 & 3.93 & 236.1 & 76.7 & 4.5 & 253.8 & 0.32 & 54.2 & 10.33 & 0.8 & 59.94 \\
\hline & 13 & 51.3 & 4.1 & 158.8 & 76.6 & 4.9 & 176.4 & 0.48 & 37.1 & 5.8 & 0.76 & 47.99 \\
\hline & 27 & 52 & 4.16 & 177.2 & 127 & 0 & 206.4 & 0.72 & 39.3 & 2.13 & 0.67 & 35.18 \\
\hline & 102 & 54.3 & 4.35 & 212.7 & 57.4 & 0 & 226 & 0.27 & 50.8 & 5.77 & 0.76 & 49.26 \\
\hline & 139 & 54.5 & 4.36 & 131.6 & 40.3 & 1.8 & 140.9 & 0.31 & 33.9 & 15.11 & 0.81 & 63.71 \\
\hline & 109 & 86.7 & 6.94 & 103.8 & 41.7 & 1.2 & 113.4 & 0.4 & 41.6 & 7.86 & 0.78 & 53.04 \\
\hline \multirow[t]{10}{*}{$15 \mathrm{VC} 01$} & 32 & 82.1 & 6.57 & 358.2 & 164.5 & 0 & 396.1 & 0.46 & 128 & 3.02 & 0.72 & 41.95 \\
\hline & 50 & 67.2 & 5.38 & 599.5 & 313.4 & 3.5 & 671.6 & 0.52 & 174.5 & 2.65 & 0.71 & 40.07 \\
\hline & 33 & 48.9 & 3.91 & 237.9 & 40.5 & 0 & 247.3 & 0.17 & 48.6 & 4.04 & 0.74 & 44.41 \\
\hline & 129 & 43 & 3.44 & 44.2 & 30.3 & 0 & 51.1 & 0.69 & 9.5 & 9.93 & 0.79 & 58.31 \\
\hline & 63 & 86.5 & 6.92 & 120.4 & 49.5 & 0 & 131.8 & 0.41 & 44.5 & 2.73 & 0.72 & 40.83 \\
\hline & 84 & 45.1 & 3.61 & 251.1 & 44.3 & 0 & 261.3 & 0.18 & 47.8 & 3.7 & 0.75 & 45.76 \\
\hline & 137 & 78.6 & 6.29 & 130.5 & 92.5 & 0 & 151.8 & 0.71 & 43 & 1.65 & 0.66 & 33.9 \\
\hline & 122 & 57.2 & 4.58 & 223.2 & 47.6 & 0 & 234.1 & 0.21 & 51.3 & 2.62 & 0.71 & 38.63 \\
\hline & 29 & 80.8 & 6.47 & 54.3 & 21.5 & 2.7 & 59.3 & 0.4 & 19.2 & 3.48 & 0.74 & 44.21 \\
\hline & 8 & 67.9 & 5.43 & 273.6 & 137.1 & 0 & 305.2 & 0.5 & 78.2 & 2.54 & 0.7 & 37.67 \\
\hline \multirow{11}{*}{$\begin{array}{r}\text { 17IONF- } \\
2\end{array}$} & 14 & 40.4 & 3.23 & 88.6 & 72.7 & 0.9 & 105.3 & 0.82 & 20 & 30.54 & 0.87 & 92.59 \\
\hline & 17 & 52.9 & 4.23 & 93.3 & 25.6 & 2.2 & 99.2 & 0.27 & 21.2 & 4.31 & 0.75 & 45.19 \\
\hline & 161 & 57.5 & 4.6 & 744.2 & 298.3 & 1.9 & 812.8 & 0.4 & 194.5 & 4.95 & 0.77 & 50.49 \\
\hline & 120 & 58.3 & 4.66 & 422.6 & 226.2 & 0 & 474.7 & 0.54 & 112.8 & 4.05 & 0.75 & 47.14 \\
\hline & 64 & 62.8 & 5.02 & 386.2 & 106 & 2.9 & 410.7 & 0.27 & 119.9 & 25.26 & 0.86 & 84.66 \\
\hline & 140 & 65.1 & 5.21 & 178.1 & 73.4 & 1.6 & 195 & 0.41 & 59.4 & 28.81 & 0.86 & 87 \\
\hline & 106 & 66.6 & 5.33 & 478.6 & 244.4 & 2.9 & 534.9 & 0.51 & 160.7 & 16.19 & 0.83 & 71.03 \\
\hline & 107 & 71.8 & 5.75 & 78.6 & 38.1 & 0.8 & 87.4 & 0.48 & 30.4 & 56.82 & 0.89 & 112.1 \\
\hline & 103 & 74.1 & 5.93 & 129.5 & 48.4 & 0.5 & 140.6 & 0.37 & 47.9 & 20.04 & 0.85 & 78.24 \\
\hline & 149 & 76.8 & 6.14 & 900.3 & 635.1 & 11.4 & 1046.6 & 0.71 & 360.4 & 12.42 & 0.83 & 69.18 \\
\hline & 265 & 105 & 8.4 & 760.7 & 148.5 & 3.5 & 794.9 & 0.2 & 406.4 & 64.4 & 0.89 & 114.66 \\
\hline 15MD01 & 122 & 50.6 & 4.05 & 493.8 & 186.9 & 2.3 & 536.9 & 0.38 & 123.6 & 16.48 & 0.84 & 74.36 \\
\hline & 107 & 62 & 4.96 & 71.8 & 36.6 & 1 & 80.2 & 0.51 & 21.8 & 9.08 & 0.81 & 61.89 \\
\hline & 39 & 65.1 & 5.21 & 743.6 & 234.4 & 0 & 797.5 & 0.32 & 214.8 & 4.89 & 0.76 & 49.14 \\
\hline & 28 & 68.2 & 5.45 & 286.7 & 149.3 & 0 & 321.1 & 0.52 & 89.1 & 4.27 & 0.75 & 46.79 \\
\hline & 135 & 69 & 5.52 & 731.7 & 189.9 & 3.5 & 775.4 & 0.26 & 223.8 & 5.43 & 0.77 & 50.93 \\
\hline & 144 & 73.4 & 5.87 & 1064 & 509.7 & 17.4 & 1181.4 & 0.48 & 331.3 & 2.16 & 0.7 & 38.7 \\
\hline & 18 & 78.6 & 6.29 & 33.6 & 21.3 & 1.1 & 38.5 & 0.63 & 14.2 & 32.82 & 0.86 & 88.66 \\
\hline 15MD02 & 144 & 67 & 5.36 & 374.3 & 94.4 & 6.4 & 396.1 & 0.25 & 90.9 & 1.46 & 0.63 & 29.84 \\
\hline & 39 & 71.8 & 5.75 & 376.3 & 199.3 & 0 & 422.2 & 0.53 & 117.4 & 3.01 & 0.71 & 40.23 \\
\hline & 49 & 72.2 & 5.77 & 211.7 & 176.1 & 0 & 252.2 & 0.83 & 67.2 & 1.95 & 0.68 & 35.94 \\
\hline
\end{tabular}




\begin{tabular}{|c|c|c|c|c|c|c|c|c|c|c|c|c|}
\hline U-Th)/He Age & Grain & $\begin{array}{l}\text { Age } \\
\text { Ma }\end{array}$ & $\begin{array}{c}\text { Std Err., } \\
\text { Ma* }^{*}\end{array}$ & $\begin{array}{c}\mathrm{U} \\
(\mathbf{p p m})\end{array}$ & $\begin{array}{c}\text { Th } \\
(\mathbf{p p m})\end{array}$ & $\begin{array}{l}\text { 147Sm } \\
(\mathrm{ppm})\end{array}$ & $\mathrm{eU}^{*}$ & $\mathrm{Th} / \mathrm{U}$ & $\begin{array}{c}\mathrm{He} \\
(\mathrm{nmol} / \mathrm{g})\end{array}$ & $\begin{array}{c}\text { Mass } \\
\text { (ug) }\end{array}$ & $\mathrm{Ft}^{*}$ & ESR* \\
\hline & 19 & 82.6 & 6.61 & 421.5 & 74.8 & 0 & 438.7 & 0.18 & 114.5 & 0.76 & 0.58 & 25.55 \\
\hline \multirow[t]{7}{*}{ 17TES-1 } & 93 & 57.7 & 4.61 & 255.3 & 113.8 & 2.4 & 281.6 & 0.45 & 65.4 & 3.99 & 0.74 & 45.32 \\
\hline & 99 & 69.9 & 5.6 & 881.5 & 306.1 & 17.3 & 952 & 0.35 & 255.8 & 2.72 & 0.71 & 39.1 \\
\hline & 81 & 70.1 & 5.61 & 234.7 & 131.7 & 6.2 & 265 & 0.56 & 72 & 3.03 & 0.71 & 40.43 \\
\hline & 113 & 71.1 & 5.69 & 289.5 & 149.8 & 0 & 324 & 0.52 & 85.1 & 2 & 0.68 & 35.61 \\
\hline & 51 & 77.4 & 6.19 & 373.7 & 149.7 & 3.1 & 408.2 & 0.4 & 124.1 & 3 & 0.72 & 41.68 \\
\hline & 129 & 80.6 & 6.45 & 214.3 & 135.5 & 3.3 & 245.6 & 0.63 & 86.7 & 11.34 & 0.81 & 61.81 \\
\hline & $\begin{array}{c}3 \\
57\end{array}$ & $\begin{array}{c}82.3 \\
107.5\end{array}$ & $\begin{array}{c}6.59 \\
8.6\end{array}$ & 506.8 & 152.9 & 1.5 & 542 & $\begin{array}{c}0.3 \\
0.66\end{array}$ & 187.6 & 6.24 & 0.77 & $\begin{array}{l}51.75 \\
35.61\end{array}$ \\
\hline \multirow[t]{8}{*}{ 17POR-1a } & 102 & 41.6 & 3.33 & 186.4 & 145.3 & 1.2 & 219.9 & 0.78 & 39.3 & 7.67 & 0.79 & 57.33 \\
\hline & 142 & 45.8 & 3.66 & 129 & 37.5 & 2.3 & 137.7 & 0.29 & 28.8 & 19.81 & 0.84 & 75.56 \\
\hline & 51 & 69 & 5.52 & 306.9 & 131.6 & 2.7 & 337.2 & 0.43 & 103.7 & 13.89 & 0.82 & 66.73 \\
\hline & 60 & 70.2 & 5.62 & 490.8 & 178.2 & 0.8 & 531.8 & 0.36 & 166.6 & 12.2 & 0.82 & 66.9 \\
\hline & 248 & 72.6 & 5.81 & 193.6 & 98 & 4.7 & 216.2 & 0.51 & 65.9 & 5.92 & 0.77 & 51.88 \\
\hline & 1 & 77.3 & 6.19 & 236 & 81 & 3.3 & 254.6 & 0.34 & 90.6 & 22.64 & 0.85 & 78.67 \\
\hline & 74 & 80.4 & 6.43 & 116.6 & 31.2 & 1.8 & 123.8 & 0.27 & 43.9 & 10.09 & 0.81 & 62.89 \\
\hline & 208 & 81.6 & 6.53 & 10.7 & 4.3 & 0 & 11.7 & 0.4 & 4.3 & 17.22 & 0.84 & 74.86 \\
\hline \multirow[t]{11}{*}{ 17TSSG-1 } & 22 & 44.7 & 3.57 & 666 & 464.8 & 168.6 & 773.8 & 0.7 & 129.8 & 2.88 & 0.69 & 37.47 \\
\hline & 18 & 48.5 & 3.88 & 121.2 & 89.2 & 4.7 & 141.8 & 0.74 & 27.8 & 3.99 & 0.74 & 46.04 \\
\hline & 65 & 63.2 & 5.05 & 576.6 & 283.8 & 2.3 & 641.9 & 0.49 & 160.9 & 4.11 & 0.73 & 43.23 \\
\hline & 1 & 63.2 & 5.05 & 331.6 & 148.7 & 0.8 & 365.8 & 0.45 & 102.2 & 11.13 & 0.82 & 64.6 \\
\hline & 85 & 65.4 & 5.23 & 153.5 & 111.1 & 0 & 179.1 & 0.72 & 48.6 & 5.37 & 0.76 & 50.25 \\
\hline & 29 & 71.3 & 5.7 & 107.8 & 130.9 & 3.3 & 138 & 1.21 & 38.2 & 2.86 & 0.71 & 41.17 \\
\hline & 41 & 74.9 & 6 & 449.4 & 283.5 & 3.3 & 514.7 & 0.63 & 165.4 & 8.49 & 0.79 & 56.49 \\
\hline & 63 & 78.2 & 6.25 & 282.7 & 180 & 2.4 & 324.1 & 0.64 & 101.6 & 3.89 & 0.74 & 44.69 \\
\hline & 57 & 86 & 6.88 & 67.1 & 28.6 & 1.7 & 73.7 & 0.43 & 27.7 & 10.78 & 0.81 & 60.87 \\
\hline & 94 & 111.7 & 8.94 & 466.4 & 289.9 & 9.5 & 533.1 & 0.62 & 247 & 6.84 & 0.76 & 49.47 \\
\hline & 44 & 120.3 & 9.62 & 153.1 & 55.3 & 0 & 165.8 & 0.36 & 80.2 & 3.81 & 0.74 & 44.16 \\
\hline \multirow[t]{14}{*}{ 17SIM-1 } & 54 & 61.4 & 4.91 & 329.8 & 93.1 & 1.8 & 351.3 & 0.28 & 89.1 & 5.11 & 0.76 & 48.78 \\
\hline & 58 & 61.7 & 4.93 & 156.7 & 48.8 & 0 & 167.9 & 0.31 & 41.6 & 3.58 & 0.74 & 44.67 \\
\hline & 71 & 64.8 & 5.18 & 94.3 & 40.6 & 0 & 103.6 & 0.43 & 28 & 6.75 & 0.77 & 51.09 \\
\hline & 23 & 65.5 & 5.24 & 307 & 159.7 & 5.8 & 343.8 & 0.52 & 88.5 & 3.21 & 0.72 & 41.96 \\
\hline & 119 & 66.7 & 5.34 & 213.2 & 77 & 0 & 230.9 & 0.36 & 61.9 & 3.84 & 0.74 & 44.55 \\
\hline & 124 & 67.2 & 5.37 & 256.7 & 279.1 & 2.4 & 321 & 1.09 & 86 & 3.92 & 0.73 & 44.52 \\
\hline & 29 & 69.8 & 5.58 & 89.4 & 42.3 & 0 & 99.1 & 0.47 & 26.1 & 2.41 & 0.7 & 37.58 \\
\hline & 16 & 69.8 & 5.59 & 389.7 & 93.2 & 2.3 & 411.1 & 0.24 & 116 & 4.1 & 0.75 & 45.08 \\
\hline & 89 & 71.7 & 5.74 & 128.5 & 76 & 0 & 146 & 0.59 & 39.8 & 2.57 & 0.7 & 38.28 \\
\hline & 88 & 75.6 & 6.04 & 666.5 & 59.3 & 1.6 & 680.2 & 0.09 & 218.4 & 5.96 & 0.78 & 53.32 \\
\hline & 4 & 81.4 & 6.51 & 82.6 & 71.3 & 2.2 & 99 & 0.86 & 34.8 & 8.32 & 0.79 & 58.13 \\
\hline & 40 & 106.3 & 8.51 & 82.2 & 56 & 1 & 95.1 & 0.68 & 44.2 & 8.93 & 0.8 & 60.62 \\
\hline & 11 & 111.6 & 8.93 & 199.6 & 128.1 & 1.8 & 229.1 & 0.64 & 101.7 & 5.06 & 0.73 & 43.3 \\
\hline & 136 & 205.8 & 16.47 & 67.1 & 37.4 & 0 & 75.7 & 0.56 & 52.1 & 0.89 & 0.61 & 28.53 \\
\hline \multirow[t]{11}{*}{ 17JUN-2 } & 29 & 24.3 & 1.94 & 517.7 & 31.8 & 0 & 525.1 & 0.06 & 50.4 & 3.74 & 0.73 & 42.18 \\
\hline & 129 & 30.2 & 2.42 & 145.4 & 147.3 & 1.5 & 179.3 & 1.01 & 22.7 & 6.15 & 0.77 & 53.06 \\
\hline & 43 & 32.7 & 2.62 & 384.6 & 97.7 & 0 & 407.1 & 0.25 & 49.1 & 1.95 & 0.68 & 35.15 \\
\hline & 14 & 34.9 & 2.79 & 234.6 & 45.5 & 0 & 245.1 & 0.19 & 34.2 & 3.39 & 0.74 & 43.67 \\
\hline & 125 & 41.4 & 3.31 & 500.6 & 110.8 & 5 & 526.1 & 0.22 & 87.8 & 3.77 & 0.75 & 45.06 \\
\hline & 40 & 43.1 & 3.45 & 154.8 & 71 & 0 & 171.2 & 0.46 & 29.6 & 4.51 & 0.74 & 44.82 \\
\hline & 1 & 44.5 & 3.56 & 160.4 & 20.9 & 1.8 & 165.3 & 0.13 & 33.8 & 21.11 & 0.85 & 78.16 \\
\hline & 58 & 49.2 & 3.94 & 380.4 & 162.4 & 0 & 417.8 & 0.43 & 83.7 & 4.36 & 0.75 & 46.83 \\
\hline & 98 & 54.2 & 4.33 & 292.1 & 180.1 & 3.2 & 333.6 & 0.62 & 69.7 & 2.92 & 0.71 & 40.11 \\
\hline & 19 & 105.6 & 8.44 & 48.1 & 24.1 & 0 & 53.7 & 0.5 & 19.1 & 1.14 & 0.62 & 29.22 \\
\hline & 79 & 125.1 & 10.01 & 64 & 15 & 0 & 67.5 & 0.23 & 34.5 & 4.17 & 0.75 & 46.1 \\
\hline \multirow[t]{15}{*}{ 17MAT-1 } & 45 & 29.8 & 2.38 & 229.3 & 74.2 & 0 & 246.4 & 0.32 & 29.9 & 4.41 & 0.75 & 46.99 \\
\hline & 88 & 30.6 & 2.45 & 89.4 & 25.2 & 0.3 & 95.2 & 0.28 & 13.6 & 27.88 & 0.86 & 88.35 \\
\hline & 7 & 32.7 & 2.61 & 168.9 & 79.4 & 13 & 187.2 & 0.47 & 25.5 & 5.8 & 0.77 & 51.28 \\
\hline & 61 & 32.9 & 2.64 & 429.2 & 172 & 0 & 468.7 & 0.4 & 64.6 & 5.27 & 0.77 & 51.59 \\
\hline & 66 & 39.7 & 3.17 & 432 & 211 & 2.5 & 480.6 & 0.49 & 73.9 & 3.7 & 0.72 & 40.62 \\
\hline & 33 & 43 & 3.44 & 129.4 & 40.3 & 0.5 & 138.6 & 0.31 & 27.3 & 18.66 & 0.85 & 78.15 \\
\hline & 39 & 45.9 & 3.67 & 160.3 & 31.9 & 1.1 & 167.6 & 0.2 & 35.6 & 24.94 & 0.86 & 82.38 \\
\hline & 10 & 50.1 & 4.01 & 300.8 & 235.9 & 0 & 355.1 & 0.78 & 69.6 & 3.33 & 0.72 & 41.91 \\
\hline & 8 & 51.6 & 4.13 & 531.6 & 278.1 & 0 & 595.7 & 0.52 & 116.7 & 2.28 & 0.7 & 38.31 \\
\hline & 67 & 51.8 & 4.14 & 403.4 & 157.8 & 1.3 & 439.7 & 0.39 & 94.9 & 7.01 & 0.77 & 50.59 \\
\hline & 63 & 53.4 & 4.27 & 89.5 & 42.2 & 1.7 & 99.2 & 0.47 & 25.1 & 44.25 & 0.87 & 96.39 \\
\hline & 85 & 54.3 & 4.34 & 421.6 & 69.1 & 5.3 & 437.5 & 0.16 & 99.7 & 5.34 & 0.78 & 51.53 \\
\hline & 120 & 57.6 & 4.6 & 157 & 74.7 & 0 & 174.2 & 0.48 & 38.6 & 3.38 & 0.71 & 39.71 \\
\hline & 106 & 60.9 & 4.87 & 370.4 & 335.8 & 0 & 447.7 & 0.91 & 105.1 & 2.99 & 0.71 & 40.28 \\
\hline & 82 & 65.2 & 5.22 & 877.3 & 362.2 & 14.3 & 960.7 & 0.41 & 255.7 & 5.27 & 0.75 & 46.95 \\
\hline \multirow[t]{4}{*}{ 17CWSS-2 } & 140 & 42.9 & 3.43 & 690.4 & 98.3 & 0 & 713.1 & 0.14 & 118.2 & 3.17 & 0.72 & 39.5 \\
\hline & 29 & 47.3 & 3.78 & 111.8 & 23.8 & 1.2 & 117.3 & 0.21 & 23.6 & 7.72 & 0.79 & 54.81 \\
\hline & 69 & 48.4 & 3.87 & 192.1 & 38.9 & 0 & 201 & 0.2 & 41.7 & 7.59 & 0.79 & 55.87 \\
\hline & 7 & 50.5 & 4.04 & 206.1 & 40.4 & 0 & 215.4 & 0.2 & 43.6 & 3.86 & 0.74 & 44.23 \\
\hline
\end{tabular}




\begin{tabular}{|c|c|c|c|c|c|c|c|c|c|c|c|c|}
\hline \multirow[t]{6}{*}{ 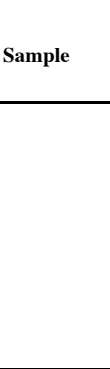 } & Grain & $\begin{array}{r}\text { Age } \\
\text { Ma }\end{array}$ & $\begin{array}{c}\text { Std } \\
\text { Err., } \mathbf{M a}^{*}\end{array}$ & $\begin{array}{c}\mathbf{U} \\
(\mathbf{p p m})\end{array}$ & $\begin{array}{c}\text { Th } \\
(\mathbf{p p m})\end{array}$ & $\begin{array}{l}147 \mathrm{Sm} \\
\text { (ppm) }\end{array}$ & $\mathrm{eU}^{*}$ & $\underset{\mathbf{U}}{\mathbf{T h}} /$ & $\begin{array}{c}\mathrm{He} \\
(\mathrm{nmol} / \mathrm{g})\end{array}$ & $\begin{array}{c}\text { Mass } \\
\text { (ug) }\end{array}$ & $\mathrm{Ft}^{*}$ * & ESR* \\
\hline & 48 & 53.3 & $\begin{array}{c}4.2 \\
7\end{array}$ & 254.1 & 178.7 & 1.7 & 295.2 & 0.7 & 68.8 & 10.82 & 0.8 & 61.55 \\
\hline & 39 & 54 & $\begin{array}{c}4.3 \\
2\end{array}$ & 370.9 & 97.6 & 1.7 & 393.3 & 0.26 & 95.5 & 16.19 & $\begin{array}{c}0.8 \\
3\end{array}$ & 69.34 \\
\hline & 94 & 59.7 & $\begin{array}{c}4.7 \\
8\end{array}$ & 372.3 & 123.5 & 4 & 400.7 & 0.33 & $\begin{array}{c}103 . \\
9\end{array}$ & 9.36 & 0.8 & 59.14 \\
\hline & 142 & 62.8 & $\begin{array}{c}5.0 \\
2\end{array}$ & 372.1 & 156 & 3.6 & 408 & 0.42 & $\begin{array}{c}104 . \\
7\end{array}$ & 5.13 & $\begin{array}{c}0.7 \\
5\end{array}$ & 47.39 \\
\hline & 8 & 63.9 & 5.1 & 246.2 & 33.5 & 2.2 & 253.9 & 0.14 & 78.1 & 54.14 & $\begin{array}{c}0.8 \\
9\end{array}$ & $\begin{array}{c}107.9 \\
3\end{array}$ \\
\hline \multirow[t]{10}{*}{ 17SES-1 } & 142 & 27.2 & $\begin{array}{c}2.1 \\
8\end{array}$ & 144.9 & 106.4 & 5.8 & 169.4 & 0.73 & 16.3 & 1.61 & $\begin{array}{c}0.6 \\
5\end{array}$ & 32.77 \\
\hline & 21 & 44.6 & $\begin{array}{c}3.5 \\
6\end{array}$ & 118.6 & 51.5 & 2.1 & 130.5 & 0.43 & 23.7 & 4.48 & $\begin{array}{c}0.7 \\
5\end{array}$ & 47.18 \\
\hline & 146 & 49.7 & $\begin{array}{c}3.9 \\
8\end{array}$ & 236.6 & 33.2 & 4.7 & 244.3 & 0.14 & 49.5 & 4.04 & $\begin{array}{c}0.7 \\
5\end{array}$ & 46.19 \\
\hline & 22 & 56.8 & $\begin{array}{c}4.5 \\
5\end{array}$ & 332.9 & 115.4 & 3 & 359.5 & 0.35 & 96.6 & 41.22 & $\begin{array}{c}0.8 \\
7\end{array}$ & 94.53 \\
\hline & 99 & 57.7 & $\begin{array}{c}4.6 \\
2\end{array}$ & 76.7 & 26.7 & 0.5 & 82.9 & 0.35 & 21.8 & 17.96 & $\begin{array}{c}0.8 \\
4\end{array}$ & 75.51 \\
\hline & 91 & 68.2 & $\begin{array}{c}5.4 \\
6\end{array}$ & 124.4 & 40.9 & 0.6 & 133.8 & 0.33 & 41.4 & 16.14 & $\begin{array}{c}0.8 \\
4\end{array}$ & 72.95 \\
\hline & 132 & 71.3 & 5.7 & 736.7 & $\begin{array}{c}1507 . \\
2\end{array}$ & $\begin{array}{c}18 . \\
7\end{array}$ & 1083.8 & 2.05 & $\begin{array}{c}323 . \\
5\end{array}$ & 6.03 & $\begin{array}{c}0.7 \\
7\end{array}$ & 52.35 \\
\hline & 32 & 73 & $\begin{array}{c}5.8 \\
4\end{array}$ & 225.8 & 122.5 & 7.5 & 254 & 0.54 & 81.4 & 10.09 & $\begin{array}{c}0.8 \\
1\end{array}$ & 62.27 \\
\hline & 68 & 75.1 & $\begin{array}{c}6.0 \\
1\end{array}$ & 75.3 & 41.3 & 4.2 & 84.8 & 0.55 & 23.9 & 2.23 & $\begin{array}{c}0.6 \\
9\end{array}$ & 37.23 \\
\hline & 98 & 77.3 & $\begin{array}{l}6.1 \\
9\end{array}$ & 177.7 & 97.4 & 1.4 & 200.1 & 0.55 & 68.5 & 13.18 & $\begin{array}{c}0.8 \\
1\end{array}$ & 64.61 \\
\hline
\end{tabular}

* Standard Error is reported in the Methods section (8\%); based on standard laboratory calibration

* $\quad[\mathrm{U}] \mathrm{e}=$ Effective Uranium (See Methods section for explanation)

* Ft correction for alpha ejection correction (Farley et al., 1996) 


\section{Appendix 6. Sources and Grain Counts for Multidimensional Scaling Analysis}

\begin{tabular}{|c|c|c|c|c|}
\hline Sample(s) & Unit & $\begin{array}{l}\text { No. of Grains } \\
\text { (This study) }\end{array}$ & $\begin{array}{c}\text { No. of Grains } \\
\text { (Published) }\end{array}$ & Source \\
\hline 15SP01 & $\begin{array}{c}\text { German Rancho } \\
\text { Fm. }\end{array}$ & $\mathrm{n}=106$ & $\begin{array}{l}\mathrm{n}=103 \\
\mathrm{n}=123 \\
\mathrm{n}=176 \\
\mathrm{n}=161\end{array}$ & $\begin{array}{c}\text { Doebbert et al., } \\
2012\end{array}$ \\
\hline $15 \mathrm{VC} 02 / 15 \mathrm{VC} 01$ & Markley Sandstone & $\begin{array}{l}n=101 \\
n=126\end{array}$ & $\begin{array}{l}\mathrm{n}=88 \\
\mathrm{n}=92\end{array}$ & Dumitru et al., 2013 \\
\hline 17IONF-2 & Ione Fm. & $\mathrm{n}=245$ & $\begin{array}{l}\mathrm{n}=95 \\
\mathrm{n}=83 \\
\mathrm{n}=92\end{array}$ & Sharman et al., 2015 \\
\hline 15MD02/15MD01 & Meganos Fm. & $\begin{array}{l}n=117 \\
n=108\end{array}$ & $\begin{array}{l}\mathrm{n}=93 \\
\mathrm{n}=94\end{array}$ & Sharman et al., 2015 \\
\hline 17TES-1 & Tesla Fm. & $\mathrm{n}=114$ & $\mathrm{n}=96$ & Sharman et al., 2015 \\
\hline $17 \mathrm{GS}-1$ & Greystone Fm. & $\mathrm{n}=102$ & $\mathrm{n}=99$ & Sharman et al., 2015 \\
\hline 17BUT-1 & Butano Fm. & $\mathrm{n}=244$ & $\begin{array}{l}n=96 n=99 \\
n=98 n=100 \\
n=89\end{array}$ & Sharman et al., 2013 \\
\hline 17POR-1a & $\begin{array}{l}\text { Point of Rocks } \\
\text { Sandstone }\end{array}$ & $\mathrm{n}=247$ & $\begin{array}{l}\mathrm{n}=95 \\
\mathrm{n}=101 \\
\mathrm{n}=97\end{array}$ & Sharman et al., 2013 \\
\hline 17TSSG-1 & $\begin{array}{l}\text { Sierra Madre } \\
\text { Unnamed Eocene } \\
\text { Sandstone }\end{array}$ & $\mathrm{n}=100$ & $\begin{array}{l}\mathrm{n}=15 \\
\mathrm{n}=12 \\
\mathrm{n}=12\end{array}$ & $\begin{array}{c}\text { Jacobsen et al., } \\
2011\end{array}$ \\
\hline $17 J U N-2$ & Juncal Fm. & $\mathrm{n}=120$ & $\begin{array}{l}\mathrm{n}=15 \\
\mathrm{n}=12 \\
\mathrm{n}=14\end{array}$ & $\begin{array}{c}\text { Jacobsen et al., } \\
2011\end{array}$ \\
\hline 17MAT-1 & Matilija Sandstone & $\mathrm{n}=102$ & $\mathrm{n}=14$ & $\begin{array}{c}\text { Jacobsen et al., } \\
2011\end{array}$ \\
\hline 17CWSS-2 & $\begin{array}{l}\text { Coldwater } \\
\text { Sandstone }\end{array}$ & $\mathrm{n}=106$ & $\mathrm{n}=14$ & $\begin{array}{c}\text { Jacobsen et al., } \\
2011\end{array}$ \\
\hline
\end{tabular}


Appendix 7. Lag-times

\begin{tabular}{|c|c|c|c|c|c|c|c|c|}
\hline Sample & Grain & $\begin{array}{c}\text { U-Pb Age } \\
\text { Ma }\end{array}$ & $\begin{array}{l}\text { Err., } \\
\text { Ma }\end{array}$ & $\begin{array}{c}(\mathrm{U}-\mathrm{Th}) / \mathrm{He} \text { Age } \\
\text { Ma }\end{array}$ & $\begin{array}{r}\text { Err., } \\
\text { Ma }\end{array}$ & $\begin{array}{l}\Delta \text { in } \mathbf{t} \\
\text { M.y.* }\end{array}$ & $\begin{array}{c}\text { Max Depo. } \\
\text { Age Ma }\end{array}$ & $\begin{array}{c}\text { Lag-time } \\
\text { M.y. }\end{array}$ \\
\hline \multirow{10}{*}{ 17BUT-1 } & 268 & 81.4 & 5.3 & 50.7 & 4.1 & 30.7 & 47.0 & 3.7 \\
\hline & 158 & 91.2 & 3.4 & 54.4 & 4.4 & 36.8 & 47.0 & 7.4 \\
\hline & 285 & 175.0 & 4.9 & 63.2 & 5.1 & 111.8 & 47.0 & 16.2 \\
\hline & 261 & 208.8 & 6.4 & 63.9 & 5.1 & 144.9 & 47.0 & 16.9 \\
\hline & 20 & 93.5 & 3.2 & 64.5 & 5.2 & 29.0 & 47.0 & 17.5 \\
\hline & 50 & 1710.1 & 37.2 & 65.3 & 5.2 & 1644.8 & 47.0 & 18.3 \\
\hline & 210 & 163.1 & 3.1 & 71.5 & 5.7 & 91.6 & 47.0 & 24.5 \\
\hline & 216 & 1365.1 & 49.0 & 82.2 & 6.6 & 1282.9 & 47.0 & 35.2 \\
\hline & 12 & 257.1 & 11.5 & 90.1 & 7.2 & 167.0 & 47.0 & 43.1 \\
\hline & 54 & 108.1 & 3.5 & 108.2 & 8.7 & -0.1 & 47.0 & 61.2 \\
\hline \multirow[t]{7}{*}{$17 \mathrm{GS}-1$} & 25 & 174.1 & 6.8 & 55.1 & 4.4 & 119.0 & 51.9 & 3.2 \\
\hline & 64 & 78.1 & 2.8 & 61.1 & 4.9 & 17.0 & 51.9 & 9.2 \\
\hline & 37 & 92.6 & 3.4 & 62.9 & 5.0 & 29.7 & 51.9 & 11.0 \\
\hline & 119 & 167.2 & 6.3 & 63.4 & 5.1 & 103.8 & 51.9 & 11.5 \\
\hline & 1 & 99.9 & 2.6 & 81.1 & 6.5 & 18.8 & 51.9 & 29.2 \\
\hline & 65 & 116.8 & 4.0 & 86.8 & 6.9 & 30.0 & 51.9 & 34.9 \\
\hline & 56 & 145.6 & 4.1 & 93.9 & 7.5 & 51.7 & 51.9 & 42.0 \\
\hline \multirow[t]{12}{*}{$15 \mathrm{SP} 01$} & 130 & 175.3 & 5.6 & 57.5 & 4.6 & 117.8 & 47.0 & 10.5 \\
\hline & 144 & 227.8 & 8.8 & 57.7 & 4.6 & 170.1 & 47.0 & 10.7 \\
\hline & 133 & 98.3 & 3.4 & 58.4 & 4.7 & 39.9 & 47.0 & 11.4 \\
\hline & 1 & 264.5 & 12.5 & 60.8 & 4.9 & 203.7 & 47.0 & 13.8 \\
\hline & 28 & 1050.6 & 57.6 & 62.5 & 5.0 & 988.1 & 47.0 & 15.5 \\
\hline & 11 & 1683.3 & 41.8 & 63.0 & 5.0 & 1620.3 & 47.0 & 16.0 \\
\hline & 59 & 153.9 & 2.5 & 65.9 & 5.3 & 88.0 & 47.0 & 18.9 \\
\hline & 135 & 290.2 & 10.6 & 68.0 & 5.4 & 222.2 & 47.0 & 21.0 \\
\hline & 40 & 242.2 & 7.6 & 70.0 & 5.6 & 172.2 & 47.0 & 23.0 \\
\hline & 5 & 100.0 & 2.1 & 74.3 & 5.9 & 25.7 & 47.0 & 27.3 \\
\hline & 85 & 1835.5 & 81.0 & 77.7 & 6.2 & 1757.8 & 47.0 & 30.7 \\
\hline & 138 & 273.3 & 8.1 & 84.9 & 6.8 & 188.4 & 47.0 & 37.9 \\
\hline \multirow[t]{10}{*}{$15 \mathrm{VCO} 2$} & 9 & 2598.6 & 84.1 & 34.8 & 2.8 & 2563.8 & 42.8 & -8.0 \\
\hline & 32 & 50.4 & 4.4 & 38.3 & 3.1 & 12.1 & 42.8 & -4.5 \\
\hline & 83 & 47.7 & 3.3 & 40.5 & 3.2 & 7.2 & 42.8 & -2.3 \\
\hline & 34 & 67.3 & 4.1 & 46.0 & 3.7 & 21.3 & 42.8 & 3.2 \\
\hline & 117 & 102.3 & 7.2 & 49.1 & 3.9 & 53.2 & 42.8 & 6.3 \\
\hline & 13 & 1410.6 & 62.9 & 51.3 & 4.1 & 1359.3 & 42.8 & 8.5 \\
\hline & 27 & 1832.4 & 83.3 & 52.0 & 4.2 & 1780.4 & 42.8 & 9.2 \\
\hline & 102 & 106.4 & 6.8 & 54.3 & 4.3 & 52.1 & 42.8 & 11.5 \\
\hline & 139 & 71.5 & 4.1 & 54.5 & 4.4 & 17.0 & 42.8 & 11.7 \\
\hline & 109 & 186.6 & 9.0 & 86.7 & 6.9 & 99.9 & 42.8 & 43.9 \\
\hline \multirow[t]{10}{*}{$15 \mathrm{VCO}$} & 129 & 48.5 & 4.5 & 43.0 & 3.4 & 5.5 & 48.5 & -5.5 \\
\hline & 33 & 53.8 & 2.2 & 48.9 & 3.9 & 4.9 & 48.5 & 0.4 \\
\hline & 122 & 75.5 & 3.1 & 57.2 & 4.6 & 18.3 & 48.5 & 8.7 \\
\hline & 50 & 103.6 & 3.3 & 67.2 & 5.4 & 36.4 & 48.5 & 18.7 \\
\hline & 32 & 108.5 & 4.8 & 82.1 & 6.6 & 26.4 & 48.5 & 33.6 \\
\hline & 84 & 158.4 & 5.0 & 45.1 & 3.6 & 113.3 & 48.5 & -3.4 \\
\hline & 137 & 162.4 & 8.3 & 78.6 & 6.3 & 83.8 & 48.5 & 30.1 \\
\hline & 63 & 171.0 & 5.3 & 86.5 & 6.9 & 84.5 & 48.5 & 38.0 \\
\hline & 8 & 218.2 & 6.6 & 67.9 & 5.4 & 150.3 & 48.5 & 19.4 \\
\hline & 29 & 1733.9 & 134.3 & 80.8 & 6.5 & 1653.1 & 48.5 & 32.3 \\
\hline \multirow[t]{10}{*}{$17 \mathrm{IONF}-2$} & 17 & 1027.5 & 108.9 & 52.9 & 4.2 & 974.6 & 47.9 & 5.0 \\
\hline & 161 & 65.9 & 6.1 & 57.5 & 4.6 & 8.4 & 47.9 & 9.6 \\
\hline & 120 & 243.3 & 8.4 & 58.3 & 4.7 & 185.0 & 47.9 & 10.4 \\
\hline & 64 & 86.4 & 3.7 & 62.8 & 5.0 & 23.6 & 47.9 & 14.9 \\
\hline & 140 & 191.1 & 17.5 & 65.1 & 5.2 & 126.0 & 47.9 & 17.2 \\
\hline & 106 & 219.7 & 7.7 & 66.6 & 5.3 & 153.1 & 47.9 & 18.7 \\
\hline & 107 & 114.2 & 3.2 & 71.8 & 5.7 & 42.4 & 47.9 & 23.9 \\
\hline & 103 & 102.8 & 3.3 & 74.1 & 5.9 & 28.7 & 47.9 & 26.2 \\
\hline & 149 & 85.2 & 3.9 & 76.8 & 6.1 & 8.4 & 47.9 & 28.9 \\
\hline & 265 & 165.5 & 9.3 & 105.0 & 8.4 & 60.5 & 47.9 & 57.1 \\
\hline
\end{tabular}




\begin{tabular}{|c|c|c|c|c|c|c|c|c|}
\hline Sample & Grain & $\begin{array}{c}\text { U-Pb Age } \\
\text { Ma } \\
\end{array}$ & $\begin{array}{c}\text { Err., } \\
\text { Ma }\end{array}$ & $\begin{array}{c}\text { (U-Th)/He Age } \\
\text { Ma } \\
\end{array}$ & $\begin{array}{r}\text { Err., } \\
\text { Ma }\end{array}$ & $\begin{array}{l}\Delta \text { in t } \\
\text { M.y.* }\end{array}$ & $\begin{array}{c}\text { Max Depo. } \\
\text { Age Ma }\end{array}$ & $\begin{array}{c}\text { Lag-time } \\
\text { M.y. }\end{array}$ \\
\hline \multirow{7}{*}{$15 \mathrm{MD} 01$} & 122 & 98.2 & 3.0 & 50.6 & 4.0 & 47.6 & 53.4 & -2.8 \\
\hline & 107 & 185.6 & 4.7 & 62.0 & 5.0 & 123.6 & 53.4 & 8.6 \\
\hline & 38 & 93.7 & 2.4 & 65.1 & 5.2 & 28.6 & 53.4 & 11.7 \\
\hline & 28 & 207.2 & 6.9 & 68.2 & 5.5 & 139.0 & 53.4 & 14.8 \\
\hline & 135 & 106.1 & 3.9 & 69.0 & 5.5 & 37.1 & 53.4 & 15.6 \\
\hline & 144 & 147.5 & 14.2 & 73.4 & 5.9 & 74.1 & 53.4 & 20.0 \\
\hline & 18 & 119.5 & 9.1 & 78.6 & 6.3 & 40.9 & 53.4 & 25.2 \\
\hline \multirow[t]{4}{*}{ 15MD02 } & 39 & 89.4 & 4.2 & 71.8 & 5.7 & 17.6 & 44.0 & 27.8 \\
\hline & 49 & 115.6 & 6.1 & 72.2 & 5.8 & 43.4 & 44.0 & 28.2 \\
\hline & 144 & 154.3 & 5.9 & 67.0 & 5.4 & 87.3 & 44.0 & 23.0 \\
\hline & 19 & 165.7 & 6.3 & 82.6 & 6.6 & 83.1 & 44.0 & 38.6 \\
\hline \multirow[t]{7}{*}{ 17TES-1 } & 93 & 189.9 & 4.8 & 57.7 & 4.6 & 132.2 & 56.4 & 1.3 \\
\hline & 99 & 97.9 & 3.1 & 69.9 & 5.6 & 28.0 & 56.4 & 13.5 \\
\hline & 81 & 124.1 & 4.2 & 70.1 & 5.6 & 54.0 & 56.4 & 13.7 \\
\hline & 51 & 217.6 & 6.4 & 77.4 & 6.2 & 140.2 & 56.4 & 21.0 \\
\hline & 129 & 132.3 & 6.4 & 80.6 & 6.4 & 51.7 & 56.4 & 24.2 \\
\hline & 3 & 162.3 & 5.2 & 82.3 & 6.6 & 80.0 & 56.4 & 25.9 \\
\hline & 57 & 423.6 & 12.3 & 107.5 & 8.6 & 316.1 & 56.4 & 51.1 \\
\hline \multirow[t]{6}{*}{ 17POR-1a } & 60 & 96.5 & 3.4 & 70.2 & 5.6 & 26.3 & 46.7 & 23.5 \\
\hline & 248 & 103.3 & 3.3 & 72.6 & 5.8 & 30.7 & 46.7 & 25.9 \\
\hline & 51 & 106.6 & 3.5 & 69.0 & 5.5 & 37.6 & 46.7 & 22.3 \\
\hline & 1 & 155.7 & 4.5 & 77.3 & 6.2 & 78.4 & 46.7 & 30.6 \\
\hline & 74 & 172.5 & 4.4 & 80.4 & 6.4 & 92.1 & 46.7 & 33.7 \\
\hline & 208 & 221.6 & 13.8 & 81.6 & 6.5 & 140.0 & 46.7 & 34.9 \\
\hline \multirow[t]{9}{*}{ 17TSSG-1 } & 18 & 172.4 & 12.7 & 48.5 & 3.9 & 123.9 & 51.9 & -3.4 \\
\hline & 65 & 81.5 & 4.6 & 63.2 & 5.1 & 18.3 & 51.9 & 11.3 \\
\hline & 1 & 225.9 & 9.8 & 63.2 & 5.1 & 162.7 & 51.9 & 11.3 \\
\hline & 85 & 270.5 & 12.5 & 65.4 & 5.2 & 205.1 & 51.9 & 13.5 \\
\hline & 29 & 223.1 & 4.7 & 71.3 & 5.7 & 151.8 & 51.9 & 19.4 \\
\hline & 41 & 167.7 & 6.0 & 74.9 & 6.0 & 92.8 & 51.9 & 23.0 \\
\hline & 57 & 1721.4 & 40.2 & 86.0 & 6.9 & 1635.4 & 51.9 & 34.1 \\
\hline & 94 & 129.9 & 6.9 & 111.7 & 8.9 & 18.2 & 51.9 & 59.8 \\
\hline & 44 & 1424.4 & 32.1 & 120.3 & 9.6 & 1304.1 & 51.9 & 68.4 \\
\hline \multirow[t]{14}{*}{ 17SIM-1 } & 54 & 235.2 & 4.2 & 61.4 & 4.9 & 173.8 & 28.5 & 32.9 \\
\hline & 58 & 94.9 & 3.5 & 61.7 & 4.9 & 33.2 & 28.5 & 33.2 \\
\hline & 71 & 262.5 & 6.0 & 64.8 & 5.2 & 197.7 & 28.5 & 36.3 \\
\hline & 23 & 86.0 & 4.3 & 65.5 & 5.2 & 20.5 & 28.5 & 37.0 \\
\hline & 119 & 85.1 & 3.8 & 66.7 & 5.3 & 18.4 & 28.5 & 38.2 \\
\hline & 124 & 164.6 & 3.9 & 67.2 & 5.4 & 97.4 & 28.5 & 38.7 \\
\hline & 29 & 255.4 & 9.7 & 69.8 & 5.6 & 185.6 & 28.5 & 41.3 \\
\hline & 16 & 1618.2 & 63.3 & 69.8 & 5.6 & 1548.4 & 28.5 & 41.3 \\
\hline & 89 & 1649.3 & 37.7 & 71.7 & 5.7 & 1577.6 & 28.5 & 43.2 \\
\hline & 88 & 1730.0 & 30.7 & 75.6 & 6.0 & 1654.4 & 28.5 & 47.1 \\
\hline & 4 & 175.5 & 7.1 & 81.4 & 6.5 & 94.1 & 28.5 & 52.9 \\
\hline & 40 & 1389.8 & 63.7 & 106.3 & 8.5 & 1283.5 & 28.5 & 77.8 \\
\hline & 11 & 180.5 & 5.3 & 111.6 & 8.9 & 68.9 & 28.5 & 83.1 \\
\hline & 136 & 239.9 & 15.1 & 205.8 & 16.5 & 34.1 & 28.5 & 177.3 \\
\hline \multirow[t]{11}{*}{$17 J U N-2$} & 29 & 1514.0 & 71.6 & 24.3 & 1.9 & 1489.7 & 48.1 & -23.8 \\
\hline & 129 & 65.0 & 2.2 & 30.2 & 2.4 & 34.8 & 48.1 & -17.9 \\
\hline & 43 & 56.2 & 5.3 & 32.7 & 2.6 & 23.5 & 48.1 & -15.4 \\
\hline & 14 & 1730.4 & 52.9 & 34.9 & 2.8 & 1695.5 & 48.1 & -13.2 \\
\hline & 125 & 178.9 & 15.9 & 41.4 & 3.3 & 137.5 & 48.1 & -6.7 \\
\hline & 40 & 95.5 & 2.7 & 43.1 & 3.4 & 52.4 & 48.1 & -5.0 \\
\hline & 1 & 178.8 & 7.2 & 44.5 & 3.6 & 134.3 & 48.1 & -3.6 \\
\hline & 58 & 104.8 & 3.4 & 49.2 & 3.9 & 55.6 & 48.1 & 1.1 \\
\hline & 98 & 110.0 & 2.3 & 54.2 & 4.3 & 55.8 & 48.1 & 6.1 \\
\hline & 19 & 381.5 & 15.0 & 105.6 & 8.4 & 275.9 & 48.1 & 57.5 \\
\hline & 79 & 341.8 & 16.5 & 125.1 & 10.0 & 216.7 & 48.1 & 77.0 \\
\hline $17 M A T-1$ & 88 & 69.7 & 2.2 & 30.6 & 2.4 & 39.1 & 42.9 & -12.3 \\
\hline
\end{tabular}




\begin{tabular}{|c|c|c|c|c|c|c|c|c|}
\hline Sample & Grain & $\begin{array}{c}\text { U-Pb Age } \\
\text { Ma }\end{array}$ & $\begin{array}{l}\text { Err., } \\
\text { Ma }\end{array}$ & $\begin{array}{l}\text { (U-Th)/He } \\
\text { Age (Ma) }\end{array}$ & $\begin{array}{r}\text { Err., } \\
\text { Ma }\end{array}$ & $\begin{array}{l}\Delta \text { in t } \\
\text { M.y.* }\end{array}$ & $\begin{array}{c}\text { Max Depo. } \\
\text { Age Ma }\end{array}$ & $\begin{array}{c}\text { Lag-time } \\
\text { M.y. }\end{array}$ \\
\hline & 33 & 71.9 & 5.3 & 43.0 & 3.4 & 28.9 & 42.9 & 0.1 \\
\hline & 61 & 77.9 & 3.9 & 32.9 & 2.6 & 45.0 & 42.9 & -10.0 \\
\hline & 45 & 99.9 & 2.3 & 29.8 & 2.4 & 70.1 & 42.9 & -13.1 \\
\hline & 120 & 100.9 & 3.2 & 57.6 & 4.6 & 43.3 & 42.9 & 14.7 \\
\hline & 66 & 146.6 & 18.2 & 39.7 & 3.2 & 106.9 & 42.9 & -3.2 \\
\hline & 106 & 168.8 & 4.8 & 60.9 & 4.9 & 107.9 & 42.9 & 18.0 \\
\hline & 10 & 170.2 & 5.2 & 50.1 & 4.0 & 120.1 & 42.9 & 7.2 \\
\hline & 8 & 171.5 & 5.2 & 51.6 & 4.1 & 119.9 & 42.9 & 8.7 \\
\hline & 7 & 1120.3 & 163.1 & 32.7 & 2.6 & 1087.6 & 42.9 & -10.2 \\
\hline & 85 & 1428.3 & 102.9 & 54.3 & 4.3 & 1374.0 & 42.9 & 11.4 \\
\hline & 82 & 1367.3 & 57.1 & 65.2 & 5.2 & 1302.1 & 42.9 & 22.3 \\
\hline & 39 & 1681.7 & 64.9 & 45.9 & 3.7 & 1635.8 & 42.9 & 3.0 \\
\hline & 67 & 1690.9 & 130.9 & 51.8 & 4.1 & 1639.1 & 42.9 & 8.9 \\
\hline & 63 & 1660.4 & 69.8 & 53.4 & 4.3 & 1607.0 & 42.9 & 10.5 \\
\hline \multirow[t]{9}{*}{$17 C W S S-2$} & 140 & 68.0 & 2.8 & 42.9 & 3.4 & 25.1 & 35.5 & 7.4 \\
\hline & 29 & 1721.8 & 51.2 & 47.3 & 3.8 & 1674.5 & 35.5 & 11.8 \\
\hline & 69 & 1399.3 & 12.4 & 48.4 & 3.9 & 1350.9 & 35.5 & 12.9 \\
\hline & 7 & 1687.5 & 61.6 & 50.5 & 4.0 & 1637.0 & 35.5 & 15.0 \\
\hline & 48 & 165.1 & 5.5 & 53.3 & 4.3 & 111.8 & 35.5 & 17.8 \\
\hline & 39 & 93.1 & 3.5 & 54.0 & 4.3 & 39.1 & 35.5 & 18.5 \\
\hline & 94 & 1385.2 & 38.9 & 59.7 & 4.8 & 1325.5 & 35.5 & 24.2 \\
\hline & 142 & 172.9 & 7.9 & 62.8 & 5.0 & 110.1 & 35.5 & 27.3 \\
\hline & 8 & 87.2 & 3.2 & 63.9 & 5.1 & 23.3 & 35.5 & 28.4 \\
\hline \multirow[t]{9}{*}{ 17SES-1 } & 142 & 36.9 & 3.2 & 27.2 & 2.2 & 9.7 & 36.9 & -9.6 \\
\hline & 22 & 100.2 & 2.7 & 56.8 & 4.5 & 43.4 & 36.9 & 20.0 \\
\hline & 98 & 119.5 & 11.3 & 77.3 & 6.2 & 42.2 & 36.9 & 40.5 \\
\hline & 32 & 167.7 & 4.5 & 73.0 & 5.8 & 94.7 & 36.9 & 36.1 \\
\hline & 132 & 172.8 & 5.1 & 71.3 & 5.7 & 101.5 & 36.9 & 34.4 \\
\hline & 99 & 217.2 & 10.5 & 57.7 & 4.6 & 159.5 & 36.9 & 20.8 \\
\hline & 91 & 1458.0 & 31.3 & 68.2 & 5.5 & 1389.8 & 36.9 & 31.3 \\
\hline & 146 & 1749.9 & 19.6 & 49.7 & 4.0 & 1700.2 & 36.9 & 12.9 \\
\hline & 68 & 1727.1 & 51.8 & 75.1 & 6.0 & 1652.0 & 36.9 & 38.2 \\
\hline
\end{tabular}

$* \Delta$ in $\mathrm{t}=\mathrm{U}-\mathrm{Pb}$ Age $(\mathrm{Ma})-(\mathrm{U}-\mathrm{Th}) / \mathrm{He}$ Age $(\mathrm{Ma})$

* Mean depositional age used to avoid bias in lag-time (see Table 3 for details)

*Lag-time is based on best depositional age and the (U-Th)/He age (Ma) [Lag-time (M.y.) = (U-Th)/He Age (Ma) - Depositional Age (Ma)

*Max Depositional Age (Ma) is taken from this study's youngest single U-Pb age grain (see Table 3 for details) or estimated depositional age from literature

*Negative lag-times are acceptable if within (U-Th)/He or depositional age errors.

*Emboldened grains indicate they are volcanic (U-Pb and (U-Th)/He ages are within standard error of (U-Th)/He age)

*Italicized grains indicate reset samples not used for further interpretations 